\title{
Formação de conceitos por crianças com paralisia cerebral: um estudo exploratório sobre a influência das brincadeiras
}

\author{
Dissertação apresentada ao Instituto de Psicologia \\ da Universidade de São Paulo para a obtenção do \\ título de Mestre. Área de concentração: Psicologia \\ Escolar e do Desenvolvimento Humano - Linha de \\ Pesquisa: Desenvolvimento e Aprendizagem.
}

Orientador: José Fernando Bitencourt Lomônaco. 
AUTORIZO A REPRODUÇÃO E DIVULGAÇÃO TOTAL OU PARCIAL DESTE TRABALHO, POR QUALQUER MEIO CONVENCIONAL OU ELETRÔNICO, PARA FINS DE ESTUDO E PESQUISA, DESDE QUE CITADA A FONTE.

Catalogação na publicação

Serviço de Biblioteca e Documentação

Instituto de Psicologia da Universidade de São Paulo

Cazeiro, Ana Paula Martins.

Formação de conceitos por crianças com paralisia cerebral: um estudo exploratório sobre a influência das brincadeiras / Ana Paula Martins Cazeiro; orientador José Fernando Bitencourt Lomônaco. -São Paulo, 2008.

$301 \mathrm{p}$.

Dissertação (Mestrado - Programa de Pós-Graduação em Psicologia. Área de Concentração: Psicologia Escolar e do Desenvolvimento Humano) - Instituto de Psicologia da Universidade de São Paulo.

1. Formação de conceito 2. Paralisia cerebral 3. Brincadeiras 4. Terapia ocupacional I. Título. 
Ana Paula Martins Cazeiro.

Formação de conceitos por crianças com paralisia cerebral: um estudo exploratório sobre a influência das brincadeiras.

Dissertação apresentada ao Instituto de Psicologia da Universidade de São Paulo para a obtenção do título de Mestre.

Área de concentração: Psicologia Escolar e do Desenvolvimento Humano.

Aprovado em: de de

\section{Banca examinadora}

Prof. Dr.

Instituição:

Assinatura:

Prof. Dr.

Instituiç̧ão: Assinatura:

Prof. Dr.

Instituição: Assinatura: 
Agradecimentos...

Agradeço aos colaboradores do Instituto de Natação e Recuperação Águas Cristalinas (SP), da Associação Quero-quero (SP) e da Clínica-escola de Terapia Ocupacional da Faesa (ES), pelas portas que me foram abertas. Agradeço especialmente aos pais e crianças que participaram desta pesquisa, pela confiança e por terem partilhado comigo momentos muito especiais.

Agradeço à minha mãe por ter sido sempre meu porto seguro, ao meu pai por tanto trabalho e investimento, ao meu marido por tanto amor, paciência, estímulo e apoio. Agradeço às minhas irmãs pelo amor incondicional, aos meus sogros pelo apoio cotidiano e aos meus cunhados por me acolherem como irmã. Agradeço aos meus sobrinhos por colorirem a minha vida. Agradeço aos meus amigos, pela força e por compreenderem as ausências.

Agradeço ao professor José Fernando Bitencourt Lomônaco por toda a aprendizagem, explícita e implícita, por ter me ensinado a ensinar com generosidade e por ter sido meu orientador desde o início desta jornada, tornando-a muito mais tranqüila e agradável.

Agradeço a Deus por ter colocado todas estas pessoas em meu caminho. 


\section{RESUMO}

CAZEIRO, A.P.M. Formação de conceitos por crianças com paralisia cerebral: um estudo exploratório sobre a influência das brincadeiras. 2008. 301 f. Dissertação (Mestrado) Instituto de Psicologia, Universidade de São Paulo, SP, 2008.

O desenvolvimento de conceitos básicos ocorre em situações cotidianas e lúdicas, por meio do contato da criança com os objetos e pessoas presentes em seu ambiente. A criança com deficiência, contudo, vê-se muitas vezes privada de tais experiências, seja por conta de sua incapacidade motora, que restringe a exploração ativa, seja em decorrência da falta de oportunidades para participar de atividades lúdicas, familiares e sociais, seja pelo excesso de proteção por parte de seus cuidadores. Visando estimular o desenvolvimento desta criança e fornecer-lhe oportunidades para vivenciar situações comuns a infância, o terapeuta ocupacional utiliza-se, com freqüência, da atividade lúdica. Consoante esta prática, o objetivo desta pesquisa é investigar a influência deste tipo de atividade no processo de formação de conceitos básicos por crianças com seqüelas de paralisia cerebral. Em face das dificuldades de se trabalhar com este tipo de população, optou-se por realizar uma pesquisa do tipo qualitativo com um pequeno número de participantes, os quais foram submetidos a um pré-teste, a fim de avaliar o grau de domínio inicial de alguns conceitos, 16 sessões individuais de brincadeiras que envolviam alguns dos conceitos avaliados e reaplicação do teste inicial a fim de avaliar o grau de aprendizagem final dos conceitos trabalhados. A prova utilizada foi uma adaptação do Teste de Conceitos Básicos de Boehm. A pesquisadora, que participava das brincadeiras junto à criança, nomeava sempre que possível os conceitos pertinentes a cada situação. Todas as crianças participantes aprenderam ao menos um dos conceitos mais trabalhados durante as sessões de brincadeiras, além de terem aprendido outros conceitos não avaliados por meio dos testes. Também se verificou que as crianças apresentaram progressos em outros aspectos do seu desenvolvimento, tais como coordenação motora, atenção, qualidade da participação nas brincadeiras, comportamento e relacionamento interpessoal. Verificou-se, assim, que o fornecimento de oportunidades para participar de brincadeiras mediadas por um adulto influencia positivamente o processo de formação de conceitos básicos, bem como o desenvolvimento global da criança com seqüelas de paralisia cerebral. Estes resultados foram discutidos segundo o referencial teórico da psicologia sócio-histórica de Vygotsky.

Palavras-chave: Formação de conceito, paralisia cerebral, brincadeiras, Terapia Ocupacional. 
CAZEIRO, A.P.M. Concept development by children with cerebral palsy: an exploratory study about the influence of play. 2008. 301 p. Master’s Dissertation - Instituto de Psicologia, Universidade de São Paulo, SP, 2008.

The development of basic concepts occurs in everyday situations and play activities, by children's contact with objects and persons present in their environment. However, the disabled children are often deprived of such experiences, either on account of their motor disability that restricts the active exploration, or as a result of the lack of opportunities for play and participate in familiar or social tasks, often because of over-protection by their caretakers. To stimulate the development of the child and give him opportunities to experience situations common to all children, the occupational therapist uses often playthings. Consonant with this practice, the objective of this research was to investigate the influence of this type of activity in the process of formation of basic concepts by children with cerebral palsy. In face of the difficulties of working with this kind of population, it was decided to conduct a qualitative research with a small number of participants, which have been submitted to: a pre-test to assess the degree of initial domain of some concepts; 16 individual sessions of play therapy involving some of the evaluated concepts; a second administration of the initial test to assess the degree of learning of the treated concepts. The test administered was an adaptation of the Boehm Test of Basic Concepts. The researcher, who went on to play with child, named whenever possible the concepts relevant to each situation. All children learned at least one of the concepts more treated during the sessions of play therapy. They learned also other concepts not evaluated by tests. It was also found that children showed progress in other aspects of their development, such as motor coordination, attention, play skills, behavior and interpersonal relationships. It is therefore clear that the provision of play opportunities, mediated by an adult, positively influences the process of formation of basic concepts, as well as the overall development of children with cerebral palsy. These results were discussed according to the Vygotskyan perspective.

Keywords: Concept formation, cerebral palsy, play, Occupational Therapy. 


\section{SUMÁRIO}

APRESENTAÇÃ

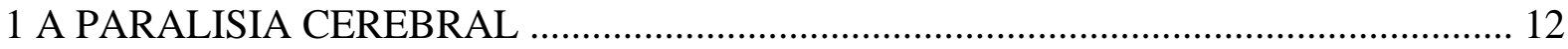

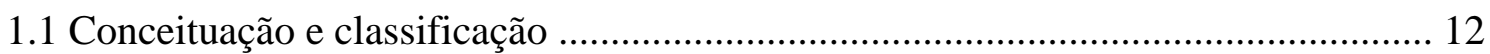

1.2 Pesquisas sobre o desenvolvimento cognitivo de crianças com paralisia cerebral .. 18

1.3 Paralisia cerebral e Terapia Ocupacional ................................................................ 22

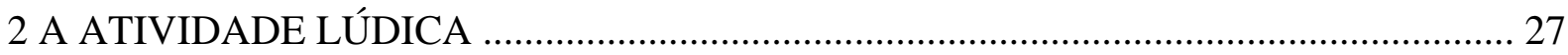

2.1 Definições e benefícios da atividade lúdica ......................................................... 27

2.2 A atividade lúdica e a criança com deficiência ..................................................... 38

2.3 A atividade lúdica e a Terapia Ocupacional ........................................................ 46

2.4 A atividade lúdica e a relação adulto/criança .................................................... 53

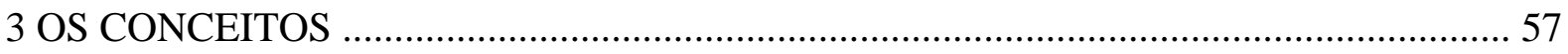

3.1 Teorias sobre a formação de conceitos ............................................................... 57

3.2 Pesquisas sobre a formação de conceitos por crianças com deficiência ................ 67

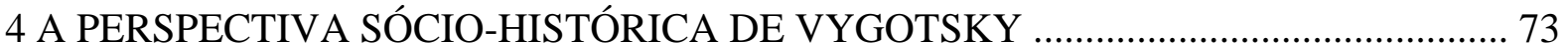

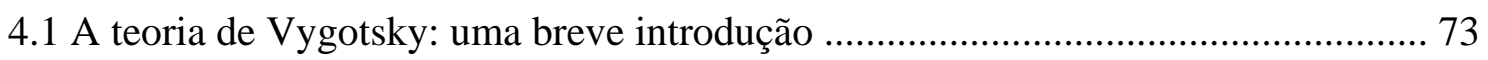

$4.2 \mathrm{O}$ processo de formação de conceitos ................................................................ 83

4.3 Vygotsky e o desenvolvimento de crianças com deficiência ............................... 101

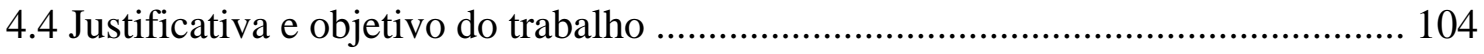

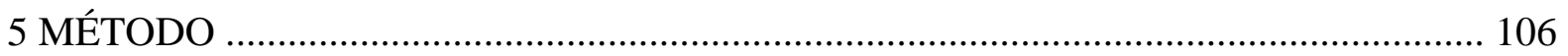

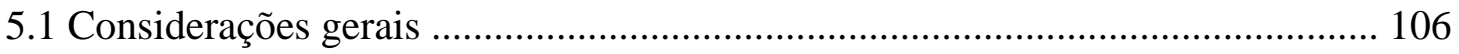

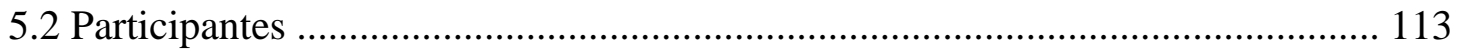

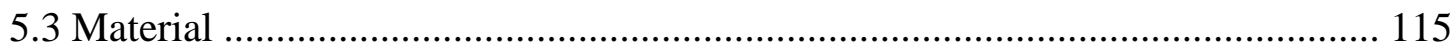


5.3.1 Teste de Conceitos Básicos de Boehm

5.3.2 Questionários para os cuidadores .................................................... 120

5.3.3 Roteiro para análise das atividades lúdicas ..................................... 121

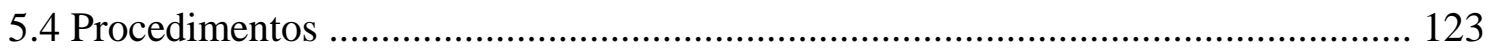

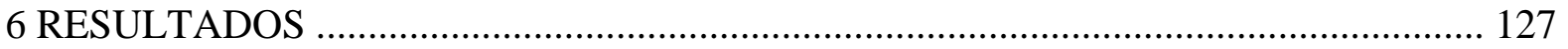

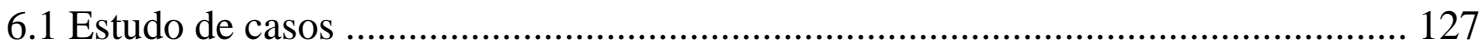

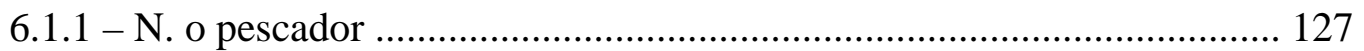

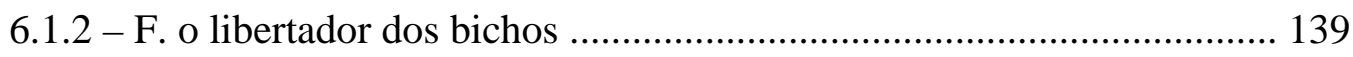

6.1 .3 - B. a lançadora de bolas ................................................................. 153

6.1.4 - FR. o competidor ...................................................................... 166

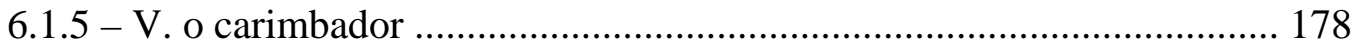

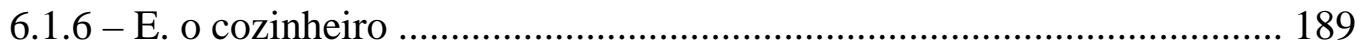

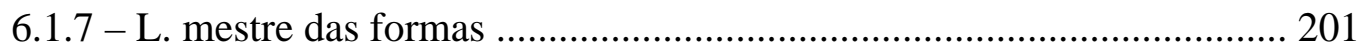

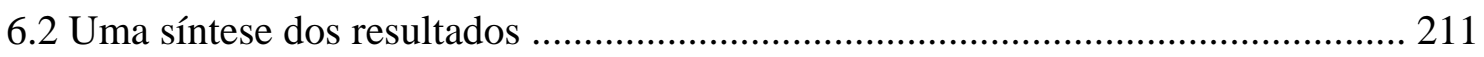

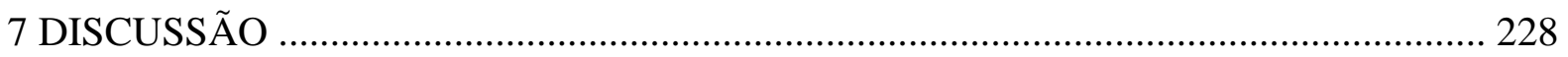

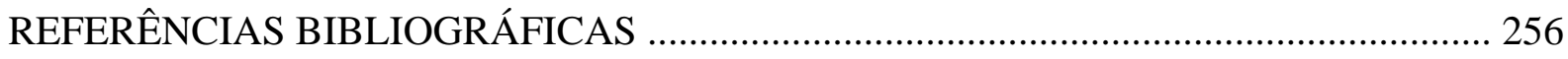

APÊNDICE A - Termo de consentimento livre e esclarecido ........................................... 266

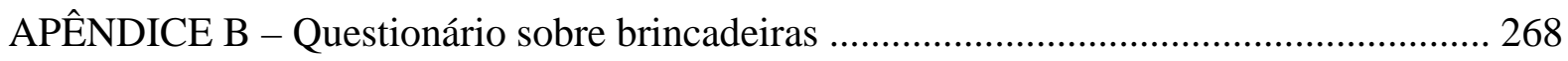

APÊNDICE C - Questionário sobre o desenvolvimento e a participação da criança .......... 270

APÊNDICE D - Brincadeiras selecionadas para a pesquisa ........................................... 271 


\section{APRESENTAÇÃO}

Na minha atuação como terapeuta ocupacional, pude perceber que muitas crianças com seqüelas de paralisia cerebral em idade escolar pareciam não compreender alguns conceitos muitos simples, relacionados a noções de tempo, espaço, tamanho e quantidade. Embora a deficiência motora decorrente da lesão encefálica possa ser acompanhada de alterações no desenvolvimento cognitivo, o atraso no desenvolvimento conceitual era também observado em crianças que aparentemente não apresentavam dificuldades em outras áreas do funcionamento cognitivo.

Por este motivo, perguntava-me se o atraso que percebia na formação de conceitos básicos não seria decorrente da falta de oportunidades para vivenciar algumas atividades, visto que este tipo de conhecimento é adquirido em situações informais, por meio do contato da criança com o ambiente e com as pessoas que a cercam.

Além das alterações motoras, que dificultam a participação da criança em algumas atividades cotidianas, lúdicas e escolares, a criança com deficiência também enfrenta outras limitações, algumas vezes geradas pela superproteção e descrença em suas capacidades, outras vezes decorrentes de barreiras arquitetônicas e atitudinais, o que acaba restringindo ainda mais as suas vivências. Como, então, esta criança poderia formar conceitos básicos, normalmente desenvolvidos em brincadeiras e atividades espontâneas, se ela era muitas vezes privada deste tipo de experiência? Ao mesmo tempo, perguntava-me se a minha intervenção, enquanto terapeuta ocupacional, favorecendo a participação da criança em atividades lúdicas e cotidianas, da maneira mais autônoma e independente possível, poderia facilitar o desenvolvimento de conceitos básicos, fundamentais para suas aprendizagens futuras. Foi a partir destas reflexões e 
questionamentos que surgiu a idéia de realizar esta investigação, que visa identificar se o oferecimento de oportunidades para participar de atividades lúdicas pode favorecer o desenvolvimento de conceitos básicos por crianças com seqüelas de paralisia cerebral.

Esta pesquisa, portanto, envolve três diferentes fatores: o desenvolvimento de crianças com paralisia cerebral, o uso da brincadeira na atuação do terapeuta ocupacional e o processo de formação de conceitos básicos. Por este motivo, fez-se necessário, inicialmente, tecer algumas considerações sobre cada um destes temas específicos.

No Capítulo 1, apresentamos o que se entende por paralisia cerebral e o que se têm pesquisado, em nosso meio, sobre o desenvolvimento cognitivo de crianças com este tipo de deficiência. Também realizamos uma breve exposição sobre o papel da Terapia Ocupacional no tratamento reabilitacional de tais crianças.

No Capítulo 2, salientamos a importância da atividade lúdica para o desenvolvimento de todas as crianças, bem como identificamos os prejuízos que a falta da brincadeira pode causar no desenvolvimento da criança com deficiência. Diante de tais prejuízos, discutimos a importância da Terapia Ocupacional e da relação adulto/criança na eliminação das barreiras ao brincar que frequentemente são impostas à criança com paralisia cerebral.

No Capítulo 3, apresentamos as diferentes visões sobre conceitos que vêm sendo desenvolvidas na Psicologia. Também mencionamos algumas pesquisas que investigaram o processo de formação de conceitos por crianças com algum tipo de deficiência.

No Capítulo 4, são apresentados alguns aspectos da teoria de Vygotsky. Esta teoria foi utilizada para fundamentar nossas discussões por dois motivos. Em primeiro lugar, porque este autor estudou todos os temas abordados nesta pesquisa - a atividade lúdica, o processo de formação de conceitos e o desenvolvimento de crianças com deficiência. Em segundo lugar, 
porque a visão positiva de Vygotsky acerca do desenvolvimento destas crianças possibilita repensarmos a nossa prática terapêutica e educacional.

O Capítulo 5 apresenta o método utilizado nesta investigação, bem como os instrumentos empregados. Os resultados obtidos por meio do teste de conceitos e dos relatos do diário de campo são apresentados no Capítulo 6. Por fim, no Capítulo 7, são tecidas algumas reflexões acerca dos resultados encontrados.

A autora deste trabalho e seu orientador almejam, com este estudo, colaborar para a compreensão da formação de conceitos por crianças com seqüelas de paralisia cerebral e destacar, mais uma vez, a importância da colaboração e/ou atuação interdisciplinar no processo de reabilitação. 


\section{CAPÍTULO 1}

\section{A PARALISIA CEREBRAL}

\subsection{Conceituação e classificação}

O termo paralisia cerebral abrange um grupo de condições que são caracterizadas por alterações motoras permanentes, decorrentes de uma lesão não-progressiva no encéfalo ainda imaturo, ocorrida antes, durante ou após o nascimento da criança. Devido a estas características, a paralisia cerebral também costuma ser denominada encefalopatia crônica não-progressiva da infância. A criança com seqüelas de paralisia cerebral apresenta padrões de movimento primitivos, tônus muscular ${ }^{1}$ alterado e controle inadequado da postura, o que interfere no seu desenvolvimento e na sua participação em atividades lúdicas, escolares e da vida diária. Esta criança, de forma associada à disfunção motora, pode ou não apresentar déficits sensoriais, perceptivos, cognitivos, de fala, de deglutição, alterações no comportamento, convulsões, entre outros, dependendo da extensão da lesão e da área encefálica atingida. Em alguns casos, múltiplos aspectos do desenvolvimento podem estar alterados, em outros casos, a criança pode manifestar características compatíveis com sua faixa etária e nível de escolaridade (CARVALHO, 1998; CIASCA; MOURA-RIBEIRO; TABAQUIM， 2006; ERHARDT; MERRILL, 2002; LEVITT, 2001; MELLO et al., 2005; SILVA, 1997).

\footnotetext{
${ }^{1}$ Tônus muscular pode ser definido como uma contração discreta e contínua do músculo em repouso ou como a resistência que o músculo oferece quando é alongado passivamente (KOHLMEYER, 2002). O tônus é a base de nossos padrões de movimento e de postura, devendo ser alto o suficiente para nos manter contra a gravidade e baixo o suficiente para permitir a movimentação suave e coordenada (THE BOBATH CENTRE, 1997). Nos casos de paralisia cerebral, o tônus muscular pode estar alterado em diferentes graus; em alguns casos, pode estar alto demais para permitir a movimentação, em outros, pode ser baixo demais para permitir a sustentação do corpo contra a gravidade, ou ainda pode ser flutuante, impedindo a estabilidade postural.
} 
A paralisia cerebral, que é uma grande causa de incapacidade na infância, pode ter diversas causas, dentre as quais se destacam: desenvolvimento intra-uterino anormal, distúrbios metabólicos, distúrbios do sistema imune, da coagulação, infecções, prematuridade, gestação múltipla, hipóxia/isquemia, traumas, convulsões e afogamento (LUNDY-EKMAN, 2004; PATO et al., 2002). De acordo com Gianni (2003), a incidência mundial da paralisia cerebral varia entre 1,5 e 2,5 por mil nascidos vivos. Em bebês prematuros com menos de $1.500 \mathrm{~g}$, esta incidência é 25 a 31 vezes maior do que em bebês nascidos a termo. Segundo Ciasca, Moura-Ribeiro e Tabaquim (2006), a incidência de paralisia cerebral é de um a dois por mil nascidos vivos apenas em países desenvolvidos, enquanto que, em países em desenvolvimento, a incidência chega a sete por mil nascidos vivos a termo. No Brasil, estes valores são desconhecidos, devido à descentralização dos dados e da não obrigatoriedade de sua notificação. Contudo, presume-se que a incidência de paralisia cerebral seja elevada, devido às más condições de vida e de saúde de grande parte da população.

Por ser a paralisia cerebral uma alteração causada por lesão no encéfalo imaturo, os sinais e sintomas expressam a área lesada e a sua extensão. A classificação da paralisia cerebral pode ser feita de acordo com o tipo de disfunção motora e com a distribuição topográfica (BRAGA, 1995; ERHARDT; MERRILL, 2002; GIANNI, 2003; LIANZA, 2001; LUNDY-EKMAN, 2004; MELO et al., 2005; TACHIDJIAN, 1995), mas não há consenso a este respeito.

Quanto ao tipo de disfunção motora, baseando-se no estado do tônus muscular e na presença ou ausência de movimentos involuntários, temos os seguintes tipos:

a) Espástico: é o tipo mais freqüente, sendo causado por lesão do neurônio motor superior $^{2}$, geralmente no córtex motor. As lesões do neurônio motor superior causam

\footnotetext{
${ }^{2}$ Ainda hoje muitos autores atribuem a paralisia cerebral espástica a lesões no sistema piramidal. De acordo com Doretto (2001), esta idéia decorre da concepção clássica de que este sistema seria o responsável pela motricidade
} 
diversas alterações relacionadas ao movimento, dentre as quais destacamos a hiperreflexia (exacerbação de reflexos cutâneos e profundos), a desorganização da ativação muscular (lentidão para iniciar o movimento e dificuldade para relaxar o músculo após a sua contração) e a espasticidade ${ }^{3}$. Embora não haja consenso, a espasticidade é comumente definida como o aumento na tensão do músculo quando ele é alongado passivamente, o que varia de acordo com a velocidade do movimento (quanto mais rápido tentamos alongar o músculo, mais resistente ele se mostra). Na criança com paralisia cerebral espástica a hipertonia muscular (aumento do tônus muscular) se mostra mais evidente nos grupos musculares flexores e adutores dos membros e é acompanhada de fraqueza dos grupos antagonistas. Este fator justifica a postura destas crianças que, normalmente, permanecem com os braços flexionados e próximos ao eixo do corpo; já os membros inferiores costumam permanecer estendidos e aduzidos. Os movimentos são limitados, requerem esforço excessivo e a falta de movimentação comumente leva a contraturas musculares e deformidades. A paralisia cerebral espástica pode ser dividida, ainda, em severa, moderada ou leve.

b) Discinético $^{4}$ : causado por uma lesão nos núcleos da base. Dentre outras funções, estes núcleos regulam o tônus e a força muscular, bem como controlam a atividade

voluntária. Contudo, já se sabe que os neurônios deste sistema não são os únicos responsáveis pelos movimentos voluntários, mas apenas pelos movimentos finos dos músculos flexores distais. Além disso, estes neurônios se encontram isolados apenas na altura das pirâmides bulbares, de modo que, em qualquer outro local de seu trajeto, uma lesão neurológica resultaria em lesão conjunta de outros neurônios. Assim sendo, a paralisia cerebral é raramente causada por lesão apenas do trato piramidal, envolvendo também a lesão de outros tratos neurais. Desta forma, a paralisia cerebral espástica passou a ser considerada como um tipo de lesão do neurônio motor superior. Esta lesão também pode ocorrer em outros casos, tais como no Acidente Vascular Encefálico (quando a lesão ocorre no encéfalo já desenvolvido) ou na Lesão Medular (quando o neurônio motor é atingido no nível da medula espinal).

${ }^{3}$ Embora a espasticidade seja apenas um dos sinais da Síndrome do Neurônio Motor Superior, alguns autores ainda utilizam o termo para designar todas as alterações decorrentes desta síndrome, o que fez com que este tipo de paralisia cerebral tenha sido tradicionalmente classificada como espástica.

${ }^{4}$ Comumente, este tipo de paralisia cerebral é denominado extrapiramidal. Esta denominação, contudo, é resultante da concepção clássica de que, enquanto o sistema piramidal seria responsável pelos movimentos voluntários, o sistema extrapiramidal seria responsável pelos movimentos automáticos. Atualmente, ambas as denominações são consideradas inadequadas (DORETTO, 2001). 
automática. Normalmente atuam inibindo os movimentos rítmicos espontâneos gerados por comandos do córtex. Quando há lesão, devido à falta desta inibição, ocorrem movimentos involuntários. Estes movimentos involuntários podem ser mais grosseiros, rápidos e proximais (como na coréia), contínuos, lentos e distais (nos casos de atetose) e/ou amplos e fixos (como na distonia). Nas lesões dos núcleos da base, além da ocorrência de movimentação involuntária, que dificulta a função da criança, também há uma flutuação do tônus muscular, ocasionando dificuldade em manter uma postura estável contra a gravidade. Também há uma alteração na inervação muscular, dificultando a estabilização e a graduação dos movimentos. Na paralisia cerebral discinética é comum a ocorrência do tipo coreoatetóide, no qual há movimentos involuntários, tanto proximais quanto distais. O termo atetose significa "sem postura fixa".

c) Atáxico: geralmente causado por lesão no cerebelo ou em suas vias. O cerebelo integra informações vindas de todas as áreas envolvidas no controle motor, atuando, assim, na coordenação motora e no controle do equilíbrio. Desta forma, quando há lesão cerebelar, há déficit na coordenação dos movimentos e no equilíbrio do corpo. Há a presença de hipotonia e hiporreflexia (redução do tônus muscular e dos reflexos, respectivamente). A presença de distúrbios da inervação recíproca ${ }^{5}$ leva a alterações que são frequentemente denominadas como: assinergia e dissinergia (distúrbio da ação coordenada entre grupos musculares que agem sincronicamente), disdiadococinesia (inabilidade em fazer movimentos alternados rápidos), dismetria (incapacidade de julgar a força, a distância e a

\footnotetext{
${ }^{5}$ A inervação recíproca é um mecanismo que coordena a ação de grupos musculares agonistas, antagonistas e sinergistas. Deste modo, quando um músculo agonista se contrai, o músculo antagonista relaxa gradualmente, permitindo que o movimento resultante seja suave e gradual. Além disso, enquanto realizamos um movimento, por exemplo, de pegar algum objeto, os músculos sinergistas também estão atuando, estabilizando o ombro na altura necessária para que a mão alcance o objeto. Quando há distúrbios da inervação recíproca há falhas neste mecanismo, de modo que os movimentos ocorrem aos trancos (quando um agonista contrai, o antagonista relaxa abruptamente) e não há estabilidade proximal (por exemplo, do ombro) para que ocorra um movimento distal (como ao pegar um objeto).
} 
velocidade do movimento para realizar alguma ação) e tremor de ação (presença de tremor ao tentar pegar algo). Visto que o cerebelo recebe informações visuais e proprioceptivas, estas crianças podem apresentar comprometimento na percepção do espaço, no esquema corporal e na lateralidade. O termo ataxia significa "falta de coordenação".

d) Hipotônico: o tônus muscular é muito baixo (hipotonia) e há diminuição dos reflexos (hiporreflexia), levando a uma resistência diminuída ao movimento passivo. A criança com hipotonia tem dificuldades em manter alguma postura contra a gravidade (como sentar-se ou ficar de pé). Na maioria das vezes, a hipotonia aparece como um estágio transitório para o surgimento da espasticidade, ataxia, atetose ou quadros mistos.

e) Misto: quando a criança apresenta quadros associados dos tipos anteriormente citados, havendo, geralmente, predomínio de um dos quadros.

A classificação quanto à distribuição topográfica é feita de acordo com os membros do corpo que são afetados, de modo que podemos encontrar os seguintes tipos:

a) Tetraparesia: comprometimento dos quatro membros, tronco e pescoço. Nestes casos, os membros superiores são tão ou mais afetados que os membros inferiores. É o tipo mais grave, estando relacionado a uma lesão difusa do córtex cerebral. A tetraparesia pode ocorrer em casos de espasticidade, atetose (ou outros quadros discinéticos), ataxia e em quadros mistos.

b) Diparesia: envolvimento dos quatro membros, mas com predomínio do comprometimento nos membros inferiores. Há, em geral, um bom controle da cabeça e uma boa função dos membros superiores. A diparesia ocorre quase que exclusivamente em casos de espasticidade; pode ocorrer, raramente, uma associação da espasticidade com a ataxia. 
c) Hemiparesia: comprometimento de um hemicorpo, causado pela lesão de apenas um dos hemisférios cerebrais. Visto que alguns neurônios motores superiores cruzam de lado na junção da medula oblonga com a medula espinhal, a lesão de um hemisfério cerebral levará ao comprometimento do hemicorpo contralateral. Praticamente todas as crianças com hemiparesia apresentam um quadro de espasticidade.

Em algumas instituições ainda são usados termos tais como duplahemiparesia ${ }^{6}$ (quando há um envolvimento dos dois hemicorpos, porém com comprometimento maior em um deles), monoparesia (envolvimento de apenas um membro do corpo) ou triparesia (envolvimento de três membros do corpo). Porém, Gianni (2003) refere preferência pelo uso das outras denominações anteriormente citadas, especificando-se o membro ou hemicorpo mais acometido (por exemplo, ao invés de dizer que a criança tem uma duplahemiparesia espástica, a autora prefere dizer que ela tem uma tetraparesia espástica com predomínio à esquerda).

Segundo Shapiro (2004), a classificação e as definições correntes de paralisia cerebral não contemplam satisfatoriamente todos os aspectos a ela relacionados e mantém algumas questões ainda não resolvidas. Uma destas questões diz respeito à idade limite em que a lesão deve ocorrer para que seja dado o diagnóstico de paralisia cerebral. Por não haver consenso a este respeito, a idade limite definida por diferentes autores varia de dois a 18 anos. Com base neste e em outros argumentos, Shapiro (2004) defende que a definição e a classificação da paralisia cerebral precisam ser revistas. A classificação apresentada anteriormente é, entretanto, a mais utilizada em nosso meio.

De acordo com Braga (1995), o desenvolvimento da criança com lesões no Sistema Nervoso Central depende de muitos fatores, de modo que se inter-relacionam aspectos orgânicos

\footnotetext{
${ }^{6}$ Na prática clínica, este termo é raramente utilizado, sendo empregado apenas quando a criança apresenta seqüelas de duas lesões neurológicas distintas, em dois momentos diferentes, em que cada lesão acometeu um hemisfério cerebral distinto.
} 
(tais como a localização e a extensão da lesão) e o contexto no qual a criança está inserida. Para Carvalho (1998), além destes fatores, as características individuais e a presença de distúrbios associados também interferem no desenvolvimento da criança. As aquisições no seu desenvolvimento ocorrerão de forma mais lenta, sendo que, em alguns casos, algumas etapas podem não ser adquiridas. Contudo, dependendo do nível de atenção que lhe é dado, a criança com paralisia cerebral tem, segundo a autora, muitas possibilidades de desenvolvimento.

Segundo Ciasca, Moura-Ribeiro e Tabaquim (2006), embora a criança com paralisia cerebral possa ter, devido à lesão encefálica, um comprometimento de alguns dos recursos neurológicos para a aprendizagem, não podemos desconsiderar que outros sistemas, tal como o sistema límbico, estejam envolvidos neste processo, de modo que um contexto facilitador pode ter resultados importantes no estímulo para a aprendizagem. Do mesmo modo, podemos pensar que uma criança com paralisia cerebral que tenha preservada sua capacidade para aprender, pode ter dificuldades neste processo devido à falta de um ambiente que forneça estimulação adequada.

\subsection{Pesquisas sobre o desenvolvimento cognitivo de crianças com paralisia cerebral}

Visto que este trabalho busca estudar a formação de conceitos por crianças com seqüelas de paralisia cerebral, considerou-se importante fazer um levantamento de pesquisas que investigaram o desenvolvimento cognitivo de crianças com este tipo de seqüela.

Eagle (1985) avaliou a aquisição da noção de permanência do objeto em um grupo de 34 crianças com quadros de tetraparesia, com idades entre nove meses e 12 anos. Os resultados indicaram que esta aquisição cognitiva precoce pode ser alcançada por crianças com deficiência física severa, sugerindo que a restrição das experiências sensório-motoras não é determinante. Foram encontradas poucas relações entre o desempenho da criança nos testes e o grau de 
severidade do quadro, a presença de movimentação ocular anormal ou o tipo de relação familiar. O autor menciona que os resultados podem estar relacionados ao nível intelectual geral e à estimulação escolar.

Rothman (1987) pesquisou a compreensão de ordens de movimento (a mudança de posição de acordo com uma ordem verbal) por 30 crianças com paralisia cerebral e 30 crianças sem deficiência, com idades variando entre quatro e 11 anos. Segundo o autor, Piaget ${ }^{7}$ relaciona a compreensão da ordem de movimento aos conceitos de movimento e velocidade. As crianças com paralisia apresentaram resultados inferiores às crianças do grupo controle. $\mathrm{O}$ autor discute, a partir disso, que a deficiência física pode interferir no desenvolvimento cognitivo das crianças com paralisia cerebral.

Braga (1986) investigou alguns fatores que podem influenciar o desenvolvimento cognitivo da criança com paralisia cerebral. Participaram 80 crianças, na faixa etária de um a cinco anos. A autora estudou o desempenho das crianças em indicadores do desenvolvimento cognitivo, no decorrer de um ano. As variáveis que se mostraram relevantes para o desenvolvimento cognitivo foram: a lesão neurológica, a interação mãe/criança, a intervenção precoce, a ocupação do pai, a escolaridade da mãe e o número de brinquedos que a criança utilizava.

Esta mesma autora realizou um outro estudo do qual participaram 34 crianças com paralisia cerebral do tipo coreoatetóide, na faixa etária de seis a 14 anos, com o objetivo de verificar a incidência de deficiência mental. Foram feitas adaptações para permitir a expressão da criança nos testes de avaliação cognitiva, diminuindo a dificuldade resultante dos movimentos involuntários. Verificou-se que 30 das 34 crianças avaliadas apresentaram desempenho compatível com o de crianças sem deficiência (BRAGA, 1995).

\footnotetext{
${ }^{7}$ PIAGET, J. The child's conception of movement and speed. New York: Ballantine, 1971.
} 
Vargha-Khadem et al. (1992) aplicaram testes de inteligência e de memória em 82 crianças com paralisia cerebral hemiparética e em um grupo de crianças sem deficiência. Os resultados mostraram que não há correlação entre o hemisfério cerebral lesionado e o desempenho em tais testes, o que é um indicativo de que ambos os hemisférios cerebrais podem desenvolver as funções da linguagem na ocorrência de um dano unilateral precoce. Embora as crianças sem quadro associado de convulsão tenham obtido resultados semelhantes aos obtidos pelo grupo controle, as crianças com quadro convulsivo apresentaram resultados inferiores, o que parece indicar que a ocorrência deste quadro ou o uso de medicamento anticonvulsivo prejudica o desenvolvimento cognitivo das crianças com paralisia cerebral.

Pfeifer (1997) comparou a aquisição de habilidades cognitivas por crianças com três anos de idade, sendo cinco crianças sem deficiência e 14 crianças com seqüelas de paralisia cerebral, divididas em três grupos de acordo com a gravidade do comprometimento motor. Foram avaliadas as seguintes áreas: associação, vocabulário, memória, esquema corporal, discriminação tátil, orientação espacial e temporal. A autora constatou uma relação entre o grau de comprometimento e as habilidades cognitivas, destacando a importância das experiências motoras para a facilitação do desenvolvimento cognitivo.

Embora a paralisia cerebral seja freqüentemente associada a atrasos no desenvolvimento cognitivo (PFEIFER, 1997; ROTHMAN, 1987), alguns autores afirmam que a criança com paralisia cerebral pode apresentar um desenvolvimento intelectual compatível com crianças da mesma faixa etária (BRAGA, 1995; EAGLE, 1985; VARGHA-KHADEM et al., 1992). Um fator que pode interferir no resultado de estudos deste tipo é a consideração de que as dificuldades motoras da criança podem dificultar seu desempenho em algumas tarefas. Tal como discutido por Ciasca, Moura-Ribeiro e Tabaquim (2006), a identificação de transtornos de aprendizagem na criança com paralisia cerebral deve ser feita criteriosamente, visto que a sua expressividade pode 
estar alterada, o que pode mascarar suas reais potencialidades. Neste sentido, enquanto Braga (1995) realizou adaptações para facilitar a participação das crianças nos testes, autores como Rothman (1987) parecem não ter considerado que as dificuldades das crianças em testes que envolvem movimentos podem ser decorrentes da dificuldade motora da criança, e não apenas de seu nível de desenvolvimento cognitivo.

Alguns autores correlacionam o desenvolvimento cognitivo da criança com paralisia cerebral com o grau de comprometimento motor (LAMÔNICA et al., 2003; PFEIFER, 1997); assim, crianças que têm maior facilidade em se locomover, explorar o ambiente e realizar as atividades infantis têm melhores condições de desenvolver suas habilidades cognitivas. Todavia, Braga (1995) e Eagle (1985) encontraram evidências de que aquisições no desenvolvimento cognitivo podem ser alcançadas por crianças com graves comprometimentos motores.

Como se pode depreender das pesquisas arroladas, diversos fatores têm sido considerados como influentes no desenvolvimento cognitivo de crianças com paralisia cerebral, tais como: gravidade do quadro motor, presença de quadros convulsivos, grau de participação em atividades lúdicas, aprendizagem escolar, interação familiar, indicadores socioeconômicos (como o nível de escolaridade e a profissão dos pais) e a realização de intervenção precoce.

Atualmente, um outro fator tem sido correlacionado ao desenvolvimento da criança com seqüelas de paralisia cerebral: a plasticidade neural. O termo plasticidade neural (ou neuroplasticidade) refere-se à capacidade do SNC de modificar suas propriedades morfológicas e funcionais, adaptando-as a alterações internas ou ambientais. A plasticidade neural diz respeito tanto às modificações decorrentes do desenvolvimento, da aprendizagem e das experiências de vida, quanto às alterações geradas por uma lesão neurológica ${ }^{8}$. Após uma lesão, o Sistema

\footnotetext{
${ }^{8}$ Durante a infância precoce, há uma considerável capacidade para a plasticidade neural. Embora o cérebro em desenvolvimento seja claramente mais plástico que o adulto, mesmo neste as conexões neuronais são continuamente
} 
Nervoso Central se utiliza da plasticidade na tentativa de restabelecer suas funções perdidas ou de fortalecer funções similares, seja por meio da recuperação de neurônios danificados, seja pela sua substituição funcional por trajetos alternativos. Diversas pesquisas vêm demonstrando que a prática induz a adaptações nas redes neuronais e produz modificações na representação cortical. Assim, o exercício e a prática de tarefas específicas mostram-se essenciais para a recuperação de habilidades como andar, alcançar e agarrar objetos, realizar os cuidados pessoais e as atividades comunitárias, mostrando a importância do tratamento reabilitacional após uma lesão encefálica (LUNDY-EKMAN, 2004; MAEGAKI et al., 1999; NUDO; FRIEL, 1999; OLIVEIRA; SALINA; ANNUNCIATO, 2001; SOBRINHO, 1995; VILLAR, 1997).

\subsection{Paralisia cerebral e Terapia Ocupacional}

Tal como ocorre no desenvolvimento cognitivo, muitos fatores também influenciam o nível de funcionalidade e participação da criança com paralisia cerebral; a localização e a extensão da lesão neurológica não são os únicos fatores determinantes. Embora seja de se esperar que crianças com comprometimentos mais graves tenham maiores dificuldades no que se refere à realização de suas atividades e à exploração de seu ambiente, o modo como cada criança enfrentará suas dificuldades, bem como o impacto que estas limitações terão em sua vida, dependerão de suas características pessoais, do apoio familiar e comunitário, da presença de distúrbios associados, bem como do suporte fornecido por alguns profissionais em alguns momentos de seu desenvolvimento.

remodeladas pela experiência e pela prática de tarefas específicas durante a aprendizagem motora, cognitiva e sensorial, bem como após uma lesão central ou periférica (CHEN; COHEN; HALLETT, 2002; JOHANSSON, 2004; NUDO E FRIEL, 1999). 
O tratamento das crianças com seqüelas de paralisia cerebral, devido à complexidade da maioria dos casos, costuma ser realizado por uma equipe interdisciplinar, que pode incluir fisioterapeuta, terapeuta ocupacional, fonoaudiólogo, psicólogo, pedagogo, neurologista, ortopedista, assistente social, dentre outros profissionais. A inserção do terapeuta ocupacional na equipe que atende a crianças com seqüelas de paralisia cerebral se justifica pelas dificuldades que estas crianças podem encontrar para a realização de atividades comuns à infância.

A Terapia Ocupacional pode ser definida como uma profissão da área da saúde que utiliza a atividade humana com objetivos terapêuticos, sendo a população atendida constituída por pessoas que, em decorrência de uma alteração motora, sensorial, psíquica ou social, tiveram seu cotidiano interrompido e apresentam dificuldades para a realização de suas atividades habituais. Neste sentido, é objetivo do terapeuta ocupacional que o indivíduo adquira o maior nível possível de independência e autonomia em todas as áreas em que gostaria de atuar, podendo envolver atividades da vida diária (como alimentar-se, tomar banho, realizar higiene pessoal e vestir-se), atividades produtivas (laborais, escolares e de cuidado domiciliar) e atividades de lazer (incluindo-se a atividade lúdica) (ERHARDT; MERRILL, 2002).

O terapeuta ocupacional pode participar do tratamento da criança com paralisia cerebral desde os seus primeiros meses de vida, visando, de modo geral, favorecer o seu desenvolvimento neuropsicomotor, dar suporte aos pais nos cuidados da criança e promover a sua inclusão escolar e social. Dependendo das necessidades e expectativas de cada criança e de cada família, a intervenção do terapeuta ocupacional pode estar voltada para diferentes objetivos específicos, tais como estimular funções cognitivas e perceptivas, propiciar a melhoria da coordenação motora global e da função manual, prevenir deformidades, favorecer a integração dos sistemas sensoriais, a independência nas atividades da vida diária e a participação ativa da criança nas atividades familiares e comunitárias. 
Para alcançar tais objetivos, o terapeuta ocupacional pode se utilizar de diferentes recursos, tais como: treino de tarefas nas quais a criança encontre dificuldades (por exemplo, treinar a troca de roupas, o uso da escova de dentes, uso do talher, treinar a escrita); confecção de órteses (aparelhos para as mãos, visando prevenir deformidades e/ou facilitar a função) e preparação de adaptações (modificações nos objetos, no ambiente ou no método das tarefas, de modo a facilitar a participação do indivíduo; por exemplo, engrossar os talheres, modificar as roupas, adaptar o lápis, modificar a torneira, etc.); prescrição e adaptação de cadeiras de rodas; orientações aos pais e professores; realização de atividades que estimulem o desenvolvimento de determinadas habilidades (ERHARDT; MERRILL, 2002; FERRARETTO; SOUZA, 1998; TEIXEIRA et al., 2003). Estas atividades, que podem ser lúdicas ${ }^{9}$, pedagógicas, artesanais, culturais, sociais, entre outras, são selecionadas pelo terapeuta ocupacional de acordo com as necessidades e interesses de cada indivíduo.

Segundo Pizzigatti (1990), atividade é tudo o que o homem faz, sendo que o homem existe em atividade. Já a atividade terapêutica é a atividade programada e dirigida a um objetivo terapêutico, constituindo-se no instrumento primordial da atuação do terapeuta ocupacional. Este profissional analisa as atividades ${ }^{10}$, visando identificar os fatores que podem favorecer o tratamento, mas também identificar as necessidades de modificação na tarefa ou nos instrumentos utilizados, possibilitando que o indivíduo participe de forma satisfatória (CASTRO et al., 2004; CREPEAU, 2002; FERRIGNO, 1997).

\footnotetext{
${ }^{9}$ A utilização da atividade lúdica na intervenção da terapia ocupacional será apresentada no capítulo 2.

${ }^{10}$ A análise de atividades é uma forma de raciocínio utilizada pelos terapeutas ocupacionais para conhecer e compreender as atividades humanas. Por meio da análise de atividades, o terapeuta identifica as habilidades necessárias para executá-las, os instrumentos utilizados, a seqüência das tarefas, as possibilidades de adaptá-las, o ambiente no qual se inserem, as relações envolvidas, seu papel na rotina diária e os significados a elas atribuídos. O terapeuta também analisa a realização das atividades pela pessoa atendida, visando identificar suas dificuldades e possibilidades. Com base neste tipo de conhecimento das atividades, o terapeuta ocupacional pode sugerir atividades e auxiliar o indivíduo na adaptação das tarefas às suas necessidades e capacidades (CASTRO et al., 2004; CREPEAU, 2002; FERRIGNO, 1997).
} 
De acordo com Bach-y-Rita (1981) e Johansson (2004), pesquisadores da área de neurociências, as atividades que são significativas para o paciente serão as mais efetivas para seu o tratamento, visto que qualquer aprendizado requer a participação ativa do indivíduo. Por esta razão, estes autores mencionam a importância de que o programa terapêutico envolva atividades funcionais, com tarefas que variam de acordo com os interesses e níveis de desenvolvimento do paciente, bem como sejam direcionadas para as suas necessidades reais, incentivando que ele participe progressivamente de todas as tarefas domiciliares e sociais.

As atividades terapêuticas, os treinos de atividades da vida diária, o uso de adaptações e os demais recursos da terapia ocupacional são utilizados não apenas para desenvolver habilidades e aprendizagens específicas e promover a independência, mas também para estimular que, desde a infância, o indivíduo com deficiência descubra suas potencialidades e interesses, percebendo-se como um cidadão ativo e capaz de realizar seus projetos de vida. Neste sentido, o estímulo para a autonomia $^{11}$ da criança com paralisia cerebral se mostra fundamental para o tratamento em terapia ocupacional. Embora estimular o maior nível possível de independência seja importante para que o indivíduo consiga realizar as atividades com o mínimo de ajuda de outras pessoas, é a autonomia que possibilitará que este indivíduo tenha a iniciativa e a segurança de tomar suas próprias decisões e fazer suas próprias escolhas.

Por isso, na assistência em terapia ocupacional, devem ser ressaltadas as capacidades da criança, e não suas dificuldades. Assim, quando usamos técnicas que foram construídas pensando na melhoria e na prevenção das disfunções sensório-motoras, nosso olhar não deve estar voltado

\footnotetext{
${ }^{11}$ A independência e a autonomia são atitudes que são construídas na relação com outras pessoas, não tendo uma relação simples com a presença ou ausência de deficiência, pois, também se relacionam com aspectos de ordem psicológica, com a realidade social e com a história de vida de cada pessoa. Assim, uma pessoa sem deficiência pode depender de outras para realizar alguma atividade. Por outro lado, uma pessoa com deficiência, mesmo sendo dependente para realizar determinadas atividades, pode ser uma pessoa autônoma. Ser autônomo não significa não precisar de ninguém, mas governar a si próprio, tomando decisões a respeito de sua própria vida (FERLAND, 2006; ROCHA, 2006).
} 
“[...] somente para o desenvolvimento motor e sensorial da criança, mas como ela pode, tendo incapacidades motoras e sensoriais, realizar atividades que componham um dia-a-dia e a sua história” (MOTTA; TAKATORI, 2001, p. 131). 


\section{CAPÍTULO 2}

\section{A ATIVIDADE LÚDICA}

\subsection{Definições e benefícios da atividade lúdica}

Embora a atividade lúdica seja um tema bastante discutido, alguns autores relatam dificuldades em encontrar uma definição que dê conta de todas as suas especificidades. Um dos motivos para tal dificuldade encontra-se no fato de que, sob o título de atividade lúdica, são incluídas diferentes atividades que, aparentemente, têm pouco em comum, como, por exemplo, jogar xadrez e encher baldinhos com areia. Uma outra dificuldade reside no fato de que um mesmo comportamento pode ou não ser considerado lúdico, dependendo da sociedade e da cultura nas quais se insere (CARVALHO, 1998; FERLAND, 2006; MORAES; CARVALHO, 1987; KISHIMOTO, 1996).

Além disso, não é possível assegurar que uma determinada ação seja ou não um jogo ou que um objeto seja ou não um brinquedo, pois, como afirma Prado (1991, p. 163), “[...] qualquer atividade pode ser lúdica, dependendo das relações que o sujeito nela estabelece consigo mesmo, com o outro e/ou com o objeto”. Outros autores corroboram esta afirmação, dizendo que nenhum material ou comportamento é lúdico em si, pois o que determina a atividade lúdica é a atitude, a intenção do participante (BOMTEMPO, 1987; DANTAS, 2002; FERLAND, 2006; KISHIMOTO, 1996). Neste sentido, Ferland (2006, p. 17) afirma: "brincar implica, além dos gestos e brinquedo, num estado de espírito particular, numa predisposição interna”.

Por ser a atividade lúdica um tema complexo, as definições dadas por diferentes autores variam bastante, dependendo do referencial teórico no qual se baseiam. 
De acordo com a teoria piagetiana, a troca que realizamos com o meio se dá em dois grandes movimentos: assimilação e acomodação. Na assimilação, o sujeito incorpora os eventos, objetos e situações às estruturas mentais já organizadas, ou seja, utiliza os recursos que já possui e atua sobre o meio. Contudo, visto que meio oferece resistências, ocorrem desequilíbrios, fazendo com que o sujeito procure por outro comportamento mais adequado, o que gera a acomodação, ou seja, a reorganização das estruturas mentais já existentes para a incorporação dos novos aspectos do ambiente. A adaptação seria resultante do equilíbrio entre a assimilação e a acomodação (OLIVEIRA, 1992; PIAGET, 1945/1975). Para Piaget (1945/1975), qualquer atividade pode se tornar jogo, desde que haja uma predominância da assimilação sobre a acomodação, ou seja, desde que o real seja submetido às vontades do "eu”. Neste sentido, toda atividade que leve à aprendizagem, que consista de uma exploração do meio para a aprendizagem de novos esquemas, não pode ser considerada jogo, pois, neste caso, há a predominância da acomodação.

Bruner (1976, 1986), de maneira semelhante, afirma que o jogo é uma projeção da vida interior para o mundo, transformando-o de acordo com nossos desejos, em contraste com a aprendizagem, mediante a qual interiorizamos o mundo externo e o fazemos parte de nós mesmos. O autor também menciona outras características do brincar: a dominância dos meios sobre os fins, o que não significa que a criança não tenha objetivos, mas que o processo é mais importante que o produto; a eliminação do risco de errar e da frustração diante do erro; a natureza voluntária, sendo o comportamento lúdico auto-iniciado; raramente é aleatório ou casual, parecendo obedecer a um plano ou a uma finalidade formal, relacionada com a sociedade em que ocorre; é divertido, mesmo que haja obstáculos; pode ser relacionado à resolução de problemas, mas de forma mais agradável; é fortemente saturado de simbolismo. 
Embora Vygotsky ${ }^{12}(1976,1998)$ também defina o brincar como uma situação imaginária, este autor salienta a necessidade de considerarmos o que motiva a criança a brincar. Segundo ele, por meio da brincadeira, a criança realiza de maneira ilusória algumas de suas necessidades não realizáveis no momento. Brincar é considerado, essencialmente, preenchimento de desejo, não de desejos isolados, mas de afetos generalizados. Porém, a criança brinca sem se dar conta dos motivos da atividade lúdica. No brincar a criança é livre, ela determina suas próprias ações, iniciando-as a partir do seu próprio “eu”.

Assim como Vygotsky, Prado (1991) acredita que haja sempre um motivo (que pode ser real ou imaginário e que pode estar mais ou menos oculto) que impulsiona a atividade lúdica; deste modo, a criança soluciona as dificuldades decorrentes da discrepância entre suas necessidades e suas condições reais. Mas, de acordo com a autora, situações que são acessíveis à criança também podem encontrar espaço de representação na brincadeira, de modo que a criança reconstitui a realidade na qual vive.

Prado (1991) define o lúdico como “[...] um conjunto complexo de elementos especificamente humanos que cria espaços de jogo entre o 'real' e o ‘imaginário', sendo que sua natureza se transforma continuamente conforme a cultura, a história e as condições objetivas em que o indivíduo e o grupo se inserem” (p. 159, grifos da autora). Tais elementos lúdicos são enumerados: o desejo (motivação intrínseca), a afetividade (vivência afetiva compartilhada), a situação imaginária e a interação criativa. De acordo com a autora, as finalidades da atividade lúdica não estão nos resultados externos ou utilitários, mas na vivência dos diversos aspectos da realidade, significativos para o sujeito que age ludicamente.

\footnotetext{
${ }^{12}$ Neste capítulo, a concepção de Vygotsky acerca da brincadeira será mencionada e comparada com a concepção de outros autores, contudo, a teoria de Vygotsky acerca do desenvolvimento cognitivo e do desenvolvimento de crianças com deficiência será apresentada e discutida em maiores detalhes no Capítulo 4.
} 
Este aspecto é também salientado por Ferland (2006), quando afirma que a brincadeira não visa um desempenho, um bem ou um serviço, além de não ter normas exteriores, envolvendo a livre escolha do participante. Esta autora define o brincar como “[...] uma atitude subjetiva em que o prazer, a curiosidade, o senso de humor e a espontaneidade se tocam; tal atitude se traduz por uma conduta escolhida livremente, da qual não se espera nenhum rendimento específico” (p. 18, grifos da autora). A atitude é a essência da brincadeira, sendo que, com ela, qualquer atividade pode ser lúdica e, sem ela, a atividade deixa de ser brincadeira para ser exercício ou tarefa.

Kishimoto (1996) sintetiza as discussões de diversos autores, mencionando alguns elementos que interligam a grande família de jogos ${ }^{13}$, sendo estes: a liberdade de ação, a motivação interna, o prazer (ou desprazer), o não-sério (contrapondo-se ao trabalho), a presença de regras (implícitas ou explícitas), a importância do processo e não do produto da ação, a incerteza dos resultados, a não-literalidade (pois a realidade interna predomina sobre a externa), a representação da realidade, o controle interno (sendo que os próprios jogadores determinam o desenvolvimento dos acontecimentos), a imaginação e a contextualização no tempo e no espaço.

Para Bruner (1976), Carvalho (1998), Ferland (2006) e Missiuna e Pollock (1991), uma das características essenciais da atividade lúdica é o prazer ou a diversão. Entretanto, Kishimoto (1996), Moraes e Carvalho (1987), Piaget (1945/1975) e Vygotsky (1976, 1998), concordam que definir a atividade lúdica pelo prazer que gera é incorreto, pois nem toda atividade lúdica é prazerosa, da mesma forma que outras atividades que não são lúdicas também podem gerar prazer. Para Dantas (2002), a característica fundamental do lúdico é o caráter livre, sendo o prazer uma conseqüência deste.

\footnotetext{
${ }^{13}$ Em alguns momentos, parece que a autora inclui na "família dos jogos” algumas brincadeiras, tais como o jogo de faz de conta
} 
Para Wallon (apud DANTAS, 2002), toda motricidade infantil é lúdica, por ter a instrumentalidade superada pela expressividade. Bruner (1973) também defende que a aquisição da brincadeira simbólica é precedida por um tipo de brincadeira precoce, cujo exercício é crucial para o desenvolvimento durante os 18 primeiros meses de vida da criança. Já para Piaget, a motricidade do bebê só pode ser considerada jogo depois que o fenômeno é apreendido e não oferece mais alimento à aprendizagem, repetindo-se por simples prazer funcional. Para Vygotsky (1976, 1998), o brincar envolve uma situação imaginária, o que é impossível para uma criança com menos de três anos de idade.

Além destas discordâncias, outra dificuldade em definir a atividade lúdica decorre do fato de que muitos autores utilizam indistintamente os termos brincar, brincadeira, brinquedo, jogo e atividade lúdica, enquanto outros autores preferem definições distintas para cada termo. De acordo com Dantas (2002), o brincar pode ser definido como atividade individual e livre, e o jogar como atividade social que supõe regras, sendo que o termo lúdico, que abrange ambos os termos, se refere ao caráter livre da atividade.

Para Prado (1991), os brinquedos são os objetos reais que servem de suporte material para as ações lúdicas, sendo que qualquer objeto pode se tornar um objeto lúdico. Neste sentido, brinquedo é qualquer instrumento material que, por sua plasticidade (possibilidades de transformação imaginária ou concreta), seu caráter atrativo e sua relevância afetiva, transforma-se em objeto lúdico em correspondência ao caráter lúdico da atividade. Segundo a autora, os brinquedos mais interessantes são os mais plásticos, os que estimulam a atividade criadora (e não a passividade) e aqueles com significado afetivo para a criança.

Segundo Kishimoto (1996), o termo jogo pode ser utilizado tanto para designar o objeto concreto (o baralho, por exemplo) quanto para designar um sistema de regras, uma estrutura seqüencial que especifica a sua modalidade e permite distingui-lo de outros jogos (por exemplo, 
jogar poker ou buraco). Ao jogar, o indivíduo está, ao mesmo tempo, executando as regras do jogo e desenvolvendo uma atividade lúdica. O brinquedo, por sua vez, supõe uma relação íntima com a criança e uma indeterminação quanto ao seu uso, permitindo várias formas de brincadeira. O brinquedo dá à criança um substituto dos objetos reais, para que ela possa manipulá-los. Contudo, o brinquedo não reproduz apenas os objetos, mas a totalidade social, o que ocorre no cotidiano, a natureza e as construções humanas. O brinquedo é o objeto que dá suporte à brincadeira, sendo esta a ação que a criança desempenha ao concretizar as regras do jogo, ao mergulhar na ação lúdica. A brincadeira é o lúdico em ação.

Embora o jogo tenha um sistema de regras específicas, que determinam a sua utilização, e o brinquedo permita um uso mais variado por parte da criança, este também possui regras implícitas e ocultas, que ordenam e conduzem a brincadeira. Deste modo, ao se passar pela mãe na brincadeira de faz de conta, a criança age de acordo com as regras sociais associadas ao papel desempenhado pela mãe (KISHIMOTO, 1996). Vygotsky $(1976,1998)$ também menciona este aspecto da brincadeira, dizendo que sua liberdade é uma liberdade ilusória, pois mesmo nas brincadeiras puramente simbólicas, as ações são subordinadas a um significado definido, visto que, nelas, a criança atua de acordo com os significados das coisas, havendo sempre regras derivadas da situação imaginária. Por outro lado, mesmo nos jogos puramente de regras, há sempre uma situação imaginária subjacente.

Apesar das definições de atividade lúdica, como demonstrado anteriormente, variarem bastante, todos os autores estudados concordam que este tipo de atividade é fundamental para o desenvolvimento da criança. 
De acordo com Schaaf (1990), o brincar é o maior veículo pelo qual a criança processa e reage às informações do ambiente. De maneira semelhante, Prado (1991, p. 157) fala da importância da brincadeira na relação da criança com seu ambiente, ao defender que as atividades lúdicas são

[...] os caminhos pelos quais as crianças se apropriam da realidade exterior ao mesmo tempo em que a recriam através da fantasia, para irem constituindo seu psiquismo, alcançando níveis mais elevados de desenvolvimento físico e mental e para que possam, assim, transformar criativamente a "realidade" (grifo do autor).

Para esta autora, as interações que as crianças estabelecem entre si, com os membros mais experientes da cultura e com os objetos externos são fundamentais para o seu desenvolvimento, pois permitem a apropriação do mundo exterior, internalizando os mediadores simbólicos.

Vygotsky $(1976,1998)$ também fala do desenvolvimento simbólico que ocorre por meio da brincadeira, salientando a sua importância para que a criança aprenda a agir na esfera cognitiva. Segundo o autor, a criança pequena age sempre de acordo com os objetos percebidos. É por meio do brincar que a criança aprende a guiar seu comportamento não apenas de acordo com a percepção imediata dos objetos em si, mas de acordo com o significado da situação. Neste caso, o significado domina e determina o comportamento da criança, pois ele é separado do objeto ao qual estava diretamente fundido. Por exemplo, a criança pode agir como se estivesse andando a cavalo (significado), mesmo que não haja um cavalo (o objeto) presente. Mas, para o autor, a criança só pode aprender a separar o significado do objeto se encontrar um pivô em algo mais. Vygotsky (1976) define “pivôs” como sendo aqueles objetos utilizados pela criança durante as atividades lúdicas, situando-se entre o real e o imaginário. Deste modo, para a criança imaginar que anda a cavalo mesmo sem o cavalo estar presente, ela precisa utilizar um outro objeto, como um cabo de vassoura colocado entre as pernas, por exemplo. Assim, ela usa o cabo de vassoura de maneira diferente do convencional e de como este objeto é usado no dia-a-dia, 
atribuindo-lhe um outro significado. Por caber em uma situação imaginaria, o cabo de vassoura é, agora, um pivô entre o real e o imaginário.

Posteriormente em seu desenvolvimento, a criança já não necessita mais de um objeto como pivô. Ela consegue agir apenas com o significado das ações. A ação assume o segundo lugar e se torna pivô; o significado é novamente separado da ação por significar outra ação. Assim, tomando-se o exemplo anterior, a criança já não necessita do cabo de vassoura, mas pode simplesmente pular com as pernas separadas como se andasse a cavalo. Desta forma, a operação com os significados das coisas e a criação de situações imaginárias fazem com que a brincadeira seja considerada um meio para o desenvolvimento do pensamento abstrato, pois permite à criança libertar-se do controle de estímulos concretos imediatos do meio (QUEIROZ E MELO, 2004; VYGOTSKY, 1976).

Segundo Vygotsky $(1976,1998)$, por meio do brincar uma criança aprende a reconhecer conscientemente suas próprias ações e se torna ciente de que todo objeto tem um significado. Para o autor, a criança se move adiante essencialmente por meio da atividade lúdica, sendo o brincar uma fonte de desenvolvimento, pois, nele, a criança está sempre acima de sua idade média e de seu comportamento diário, apresentando todas as tendências do seu desenvolvimento.

Prado (1991) concorda com Vygotsky ao dizer que, na brincadeira, a criança opera com os objetos de acordo com os 'sentidos lúdicos' que lhe atribui (sentido pessoal que os objetos adquirem na ação lúdica, ditado pelo indivíduo que brinca) e opera com significados separados das coisas (no campo do pensamento), mas apoiando-se em ações e objetos externos. Assim, ao se movimentar entre os significados culturais e os sentidos lúdicos dos objetos, a criança faz o ‘jogo dos sentidos e significados’ que lhe permite agir tanto na esfera imaginária quanto na concreta. Neste processo, a criança também se transforma, pois ocorrem mudanças internas na 
sua consciência. Mas estas redefinições não são aleatórias, pois a sua ação ocorre no plano concreto e ela opera com o sistema de significados culturalmente elaborados.

De acordo com Hartley (1971), a criança pequena desenvolve uma série de processos que são fundamentais para a aprendizagem, tais como identificação, diferenciação, generalização, classificação, agrupamento, abstração, simbolização, etc. A criança também aprende alguns conceitos básicos que são instrumentos fundamentais para o seu pensamento. Estes englobam tanto conceitos de objetos e de suas características, quanto conceitos relacionais. Na aprendizagem dos conceitos de objetos, a criança precisa experimentá-los e explorá-los diversas vezes, até que ela os conheça tão bem que não necessite mais de sua presença física para que saiba como eles são. Já os conceitos relacionais dizem respeito às relações quantitativas (número, ordenação, equivalência, tamanho, etc.), relações espaciais (proximidade, ordem e posições dos objetos no espaço, tais como em cima/embaixo e dentro/fora), relações de tempo (por exemplo, antes/depois e hoje/amanhã), entre outros. Para o desenvolvimento de tais processos e conhecimentos, a criança necessita de uma variedade de experiências concretas com os objetos e pessoas, bem como de oportunidades para repeti-las quantas vezes forem necessárias. Para a autora, estas oportunidades surgem naturalmente e de forma bastante rica por meio da brincadeira.

Kishimoto (1996) também menciona que o brinquedo estimula a representação, ou seja, a expressão de imagens que evocam aspectos da realidade. De acordo com a autora, uma representação é algo presente no lugar de algo, que permite a evocação do objeto mesmo na sua ausência. Assim, o jogo favorece a construção da representação mental e a construção da realidade por parte da criança.

Neste mesmo sentido, de acordo com Piaget (1976), por meio da brincadeira a criança pequena assimila cada objeto como algo para “ser sugado, ser chacoalhado, ser segurado”. É pela 
repetição que a criança assimila os objetos às ações e estas, então, tornam-se esquemas. Estes esquemas, para o autor, constituem o equivalente funcional dos conceitos e das relações lógicas do desenvolvimento posterior.

Bruner, de maneira similar, descreve uma criança brincando com um objeto, pela aplicação deste em uma variedade de programas de ação. Tanto na brincadeira humana quanto na de animais, o brincar pode ser visto como a prática da junção de partículas de comportamento em seqüências não costumeiras (SYLVA; BRUNER; GENOVA, 1976).

Assim sendo, as atividades lúdicas também dão oportunidades para tentar combinações de comportamentos que, sob pressão funcional, nunca poderiam ser testadas. Na brincadeira, a manipulação dos objetos não é organizada com eficiência, mas, segundo o autor, forma a base de padrões complexos de movimento que servirão para futuramente realizar atividades funcionais, desenvolvendo a destreza na manipulação de objetos (BRUNER, 1976). Segundo Kishimoto (2002, p. 145), Bruner “[...] analisa a brincadeira como saber-fazer, que possibilita a coordenação de ações mão-olho-cérebro, como competência necessária para o desenvolvimento do ser humano”.

Para Bruner (1976), o brincar também está implicado na aquisição inicial da linguagem. Suas interações estruturadas e suas regras precedem e são partes do primeiro domínio da linguagem da criança. Por meio de pesquisas sobre o assunto, o autor concluiu que a língua materna é mais rapidamente aprendida em uma situação lúdica, pois o jogo estimula a atividade combinatória em geral e, particularmente, a atividade combinatória propriamente lingüística. O que permite que uma criança desenvolva todo o seu poder combinatório não é a aprendizagem da língua ou da forma de raciocinar, mas as oportunidades que tem de jogar com a linguagem e com o pensamento (BRUNER, 1986). 
De acordo com Carvalho (1998), a atividade lúdica favorece a aquisição de habilidades necessárias para o desenvolvimento global da criança. A autora cita Vygotsky, afirmando que as relações humanas são mediadas por instrumentos e símbolos, sendo os jogos e as brincadeiras os principais instrumentos utilizados pela criança para mediar suas relações sociais. No jogo, as crianças interagem para atingir um objetivo coletivo, sendo que o seu elemento moral (compromisso de ajuda, troca e respeito assumido pela criança ao entrar no jogo), bem como a subordinação às regras, contribuem para a evolução das relações sociais. A criança vive um conflito entre seguir seus impulsos e obedecer às regras, o que coloca à prova o seu autocontrole.

Piaget (1945/1975) e La Taille (1992) também consideram o jogo de regras como paradigmático para a moralidade humana, devido aos seguintes fatos: ser uma atividade interindividual regulada por normas que, mesmo sendo herdadas pelas gerações, podem ser modificadas pelo grupo de jogadores; o respeito às regras constitui seu caráter moral, envolvendo questões de honestidade e justiça; o respeito às regras não decorre da aceitação de normas estabelecidas por uma autoridade estranha ao grupo, mas de acordos mútuos estabelecidos entre os jogadores.

Ferland (2006) também defende que a brincadeira com outras pessoas possibilita que a criança se torne um ser social, pois ela vivencia diversas situações de partilha, rivalidade, colaboração, entre outras. Além disso, por meio do brincar a criança descobre o mundo ao seu redor, descobre a si mesma, experimenta e aprende. Experimenta estratégias de ação e busca solução para os problemas, aprendendo a se controlar e a controlar o material que utiliza. O brincar, pela bagagem de experiências que traz, favorece a capacidade de adaptação da criança que poderá ser útil em outros momentos do cotidiano. O brincar desenvolve habilidades para avaliar as situações, tomar decisões, fazer escolhas, estimulando a autonomia da criança. A 
criança também experimenta a frustração, aprendendo a lidar com o fracasso. Em resumo, a brincadeira estimula as diferentes dimensões da criança: física, cognitiva, afetiva e social.

\subsection{A atividade lúdica e a criança com deficiência}

Diversos autores são unânimes ao afirmar a importância da brincadeira para o desenvolvimento motor, cognitivo, lingüístico, afetivo e social da criança. Por este motivo, é razoável admitir que a privação da atividade lúdica possa gerar incapacidades secundárias, decorrentes da falta deste tipo de experiência.

Neste sentido, Bruner (1986) relata estudos que mostram que macacos criados isoladamente, aos quais são dadas oportunidades de brincar vinte minutos diários com outros macacos, não são prejudicados em sua capacidade intelectual e em sua sociabilidade, diferentemente de outros animais completamente isolados. Almy, em 1967, já afirmava que havia evidências substanciais de que tanto crianças quanto animais privados de oportunidades para brincar, apresentam dificuldades para a aprendizagem, quando comparados àqueles que têm liberdade para brincar e explorar.

Segundo Limongi (2001, p. 196), “[...] durante o período sensório-motor, a criança construirá os conceitos práticos de tempo, espaço, causa, classificação e seriação”. Finnie (1980), neste mesmo sentido, afirma que é por meio da manipulação do seu próprio corpo e dos objetos que a cercam desde o nascimento que uma criança normal aprende como o mundo funciona e como pode agir sobre ele. Aprende, assim, as diferentes texturas, pesos, tamanhos, cores, a forma de manipular cada objeto, a posição em que se encontram ou são colocados (em cima, embaixo, dos lados, dentro ou fora), aprende a calcular distâncias e tem a oportunidade de experimentar diferentes posições de seu próprio corpo em relação ao espaço. 
No caso da criança com paralisia cerebral, segundo Peres (2004), a dificuldade em se movimentar e em realizar a exploração tal como a criança sem deficiência pode dificultar esse tipo de aprendizado mencionado por Finnie (1980), assim como dificulta “[...] o desenvolvimento de sua percepção corporal e o entendimento de sua ação no mundo, dado que os conceitos necessários para essa compreensão estão intrinsecamente ligados à experiência motora” (PERES, 2004, p. 40).

Lorens (1974) discute, nesse sentido, que nas crianças com seqüelas de paralisia cerebral podem ser esperadas alterações em muitas áreas do desenvolvimento. Essas alterações, somadas a falta de oportunidades adequadas, podem afetar a habilidade posterior da criança para desenvolver conceitualização e pensamento abstrato, para estabelecer relações adaptativas complexas, para ler, escrever e compreender conceitos numéricos. Da mesma forma, sua habilidade para o planejamento motor, desenvolvimento da percepção de forma e espaço, equilíbrio e esquema corporal podem estar prejudicados.

Segundo Penteado, Seabra e Bicudo-Pereira (1996), a redução ou a inexistência do brincar nos primeiros anos de vida da criança pode causar alterações no desenvolvimento infantil, tais como atraso no desenvolvimento neuropsicomotor, na fala e na linguagem.

A despeito de tais conhecimentos, a criança com deficiência encontra-se freqüentemente privada de algumas experiências lúdicas. Além das limitações específicas decorrentes de sua deficiência, que podem variar dependendo do tipo de comprometimento dela decorrente, outras barreiras podem ser impostas às brincadeiras desta criança, tais como as barreiras ambientais (falta de brinquedos adaptados, dificuldades de acesso aos parques, falta de tempo destinado ao brincar), as barreiras sociais (preconceitos, atitudes discriminadoras e valores culturais) e aquelas impostas por seus cuidadores (superproteção, descrença nas capacidades ou desconhecimento das necessidades da criança). Em adição, as crianças com deficiência costumam ter poucas 
oportunidades para brincar com crianças sem deficiência e possuem grande parte do seu tempo destinado a inúmeros tipos de tratamento, passando grandes períodos em atividades estruturadas que restringem a sua liberdade e a sua participação nos processos de tomada de decisão (BLANCHE, 2002; FERLAND, 2006; MISSIUNA; POLLOCK, 1991).

Para Blanche (2002), embora as incapacidades múltiplas da criança com seqüelas de paralisia cerebral possam limitar suas atividades lúdicas, escolares e de autocuidado, as limitações impostas pelas pessoas e pelo ambiente costumam ser mais restritivas que a própria deficiência da criança. Jurdi (2001) também afirma que as atividades lúdicas aparecem alteradas ou inexistentes para a criança com deficiência, sendo considerada como causa para este fenômeno a falta de expectativas positivas por parte de sua família acerca de seu futuro, o que pode levar à dificuldade em propiciar-lhe trocas e relações saudáveis que auxiliem o seu desenvolvimento.

Alguns autores alertam para o fato de que a escassez de oportunidades para brincar pode interferir de forma negativa no desenvolvimento da criança com deficiência, podendo gerar inúmeras incapacidades motoras, sociais, emocionais e cognitivas secundárias, tais como: comprometimento na capacidade de adaptação; diminuição da motivação, da imaginação e da criatividade; aumento da dependência de outras pessoas; pouca vivência do sentimento de domínio sobre o ambiente e sobre as situações; redução na autoconfiança e na auto-estima; pobre desenvolvimento de habilidades sociais; comprometimento da coordenação motora; atraso no desenvolvimento de brincadeiras simbólicas; alterações no desenvolvimento perceptivo, cognitivo e lingüístico (BLANCHE, 2002; FERLAND, 2006; MISSIUNA; POLLOCK, 1991; PENTEADO; SEABRA; BICUDO-PEREIRA, 1996). Tais incapacidades secundárias à privação do brincar limitam ainda mais as experiências lúdicas da criança, além de terem um impacto em 
seu desenvolvimento e na sua atuação posterior nos ambientes escolares, comunitários e de trabalho (MISSIUNA; POLLOCK, 1991).

Muitos estudos vêm relacionando a atividade lúdica e o desenvolvimento de crianças com diferentes tipos de deficiência. Visto que a presente pesquisa enfoca crianças com seqüelas de paralisia cerebral, serão mencionados a seguir alguns estudos que investigaram a presença ou a importância da atividade lúdica no cotidiano ou no desenvolvimento da criança com este tipo de deficiência.

Sparling, Walker e Singdahlsen (1984) investigaram o efeito do brincar educacional como um método de intervenção em crianças com paralisia cerebral. Participaram 14 crianças em idade pré-escolar, seus pais, professores e terapeutas. O brincar educacional consistiu de grupos de atividades de arte e teatro, seguindo a seqüência do desenvolvimento normal do brincar. Após sete semanas de intervenção, verificou-se uma melhora, apresentada pela maioria das crianças, quanto à coordenação motora grossa e fina, à cognição, à linguagem, a atividades da vida diária e ao desempenho sócio-emocional, assim como um aumento no valor atribuído pelos adultos ao brincar como um componente essencial do desenvolvimento da criança.

Limongi (1992) relacionou a comunicação às brincadeiras de crianças com paralisia cerebral. Participaram de seu estudo duas crianças entre sete e oito anos de idade, com paralisia cerebral espástica, com nível intelectual considerado normal e fala inteligível. Foram realizadas três sessões de aproximação da criança em seu ambiente escolar e oito sessões de observação da criança em contato com brinquedos ofertados pelo pesquisador. Os resultados permitiram situar as crianças no final do período pré-operatório, com desenvolvimento cognitivo, lingüístico e de estruturação do brinquedo adequados, havendo, entretanto, uma defasagem em relação à idade cronológica. A linguagem oral era efetiva em situações concretas e habituais, mas não quando as 
crianças eram solicitadas a lidar com situações hipotéticas e antecipações. A autora chama a atenção para a influência exercida pelos fatores social e afetivo.

Lorenzini (1999) realizou uma pesquisa da qual participaram duas mães e seus filhos com seqüelas de paralisia cerebral, com três anos de idade. O procedimento consistiu no desenvolvimento de brincadeiras em situação natural com cada uma das duplas, em 24 sessões realizadas no decorrer de seis meses de intervenção. Foram utilizados dados registrados no diário de campo e dados coletados por meio de três entrevistas, realizadas com as mães no decorrer da pesquisa, a fim de conhecer as brincadeiras que comumente realizam com seus filhos. Os resultados demonstraram que o brincar, a valorização do ambiente natural, a interação mãe/filho e esta forma de atuação profissional podem contribuir efetivamente para o desenvolvimento sensório-motor da criança.

Takatori (1999) observou o brincar no cotidiano de três crianças com paralisia cerebral, mas com possibilidade de manipulação de objetos e ausência de deficiência mental associada ao quadro. Utilizou três instrumentos: o prontuário, a entrevista com a mãe e a observação. Analisou os dados colhidos sob a luz da teoria de Winnicott, concebendo que o brincar expressa o ser da criança. A autora propõe a prática deste olhar na terapia ocupacional e propõe uma mudança de referencial na reabilitação, defendendo a necessidade de se considerar o desenvolvimento emocional da criança, ao invés de focar-se na normalização do corpo deficiente por meio dos procedimentos técnicos.

Peres (2004) estudou sete crianças com paralisia cerebral do tipo espástica, com idades entre três e seis anos, tendo por objetivo proporcioná-lhes a experiência de vivenciar as manifestações lúdicas, adequando seu ambiente escolar, estimulando seu desenvolvimento cognitivo e motor, assim como a interação entre as crianças. Foram feitas entrevistas pré e pósintervenção com as mães e professoras, e foi investigado o desenvolvimento motor e cognitivo 
das crianças por meio do Inventário Portage. As intervenções ocorreram em grupos e consistiram de 26 sessões de jogos e brincadeiras. Verificou-se uma melhora na coordenação, equilíbrio e preensão de objetos, bem como na atenção e discriminação de cores.

Carvalho (1998) realizou uma pesquisa com o objetivo de investigar como as atividades lúdicas se manifestam no cotidiano de crianças com seqüelas de paralisia cerebral. As mães de sete crianças com idades entre três anos e nove meses e dez anos e quatro meses responderam a um questionário sobre as atividades cotidianas da criança. Em seguida, duas destas crianças foram observadas em situações relacionadas ao cotidiano familiar. Os resultados mostraram que a atividade lúdica está presente no cotidiano destas crianças, tanto durante atividades diárias, quanto nas atividades de lazer e nas brincadeiras propriamente ditas. Predominam as brincadeiras de faz-de-conta, no período pré-escolar, tal como na criança sem deficiência. Contudo, as brincadeiras das crianças são limitadas devido à falta de acesso aos espaços físicos, de brinquedos adequados, de contato com outras crianças e de variação quanto aos tipos de brincadeiras. No que se refere aos jogos, predomina a utilização individual de jogos de vídeo-game, estando ausentes jogos com regras e de competição em grupos, pela falta de oportunidades de ingressar em escolas comuns, o que leva a uma tendência ao isolamento, visto que as relações das crianças ficam restritas aos familiares e parentes mais próximos. Todas estas características pioram conforme o grau de comprometimento da criança. Nas brincadeiras, a criança depende muito de sua família no suprimento de necessidades físicas de locomoção, exploração do ambiente e fornecimento de oportunidades.

Ferland $(2005,2006)$ descreve uma pesquisa ${ }^{14}$ da qual participaram 30 crianças com seqüelas de paralisia cerebral, com idades entre dois anos e cinco anos e 11 meses. Os resultados

\footnotetext{
${ }^{14}$ Dufour, M.; Ferland, F.; Gosselin, J. Relation entre le comportement ludique et la capacité fonctionnelle chez l'enfant déficient motrice cérébrale. Canadian Journal of Occupational Therapy, n. 65, p. 210-8, 1998.
} 
indicaram uma correlação entre as habilidades para brincar, o grau de lesão e a independência da criança. Deste modo, quanto menor fosse a limitação e as dificuldades para se locomover, maiores habilidades para brincar a criança apresentava. Contudo, não foram encontradas correlações entre o interesse, a maneira de brincar e as capacidades da criança, o que demonstra que a atitude lúdica e o interesse em brincar se relacionam às características pessoais da criança e não a sua deficiência. A autora conclui que, “(...) se favorecemos o desenvolvimento de habilidades de brincadeira da criança, influenciamos também sobre suas habilidades funcionais, já que estes dois elementos estão ligados entre si” (FERLAND, 2006, p. 54).

Ferland (2006) também realizou uma pesquisa na qual foram entrevistados pais de crianças com deficiência, adultos com deficiência adquirida na infância e terapeutas ocupacionais canadenses, visando identificar como a brincadeira está presente na vida da criança com incapacidade física, bem como elaborar um novo modelo de prática em terapia ocupacional, baseado no brincar. A autora notou que há pouca participação dos pais nos cuidados das crianças, sendo geralmente as mães responsáveis pelo tratamento das mesmas. Estas mães mencionam que o brincar gera prazer, mas associam a brincadeira de seus filhos ao trabalho, no sentido de favorecer o seu tratamento, visando sempre objetivos específicos, com fins educativos ou terapêuticos. As atividades que as mães consideram agradáveis para as crianças envolvem estar com pessoas e realizar atividades na água, sendo que os demais interesses mencionados têm relação com os interesses de cada família. Os adultos com deficiência relatam que os terapeutas precisam dar mais espaço para a expressão dos sentimentos negativos da criança, bem como valorizar o desenvolvimento de atitudes, não apenas de habilidades. Para eles, os terapeutas devem ajudar a criança a descobrir o que é capaz de fazer e não devem evitar a frustração, mas ensinar a criança a enfrentá-la. Também falam da importância de que os profissionais se preocupem em melhorar o presente da criança, não apenas o seu futuro. 
Como é possível observar, estas pesquisas empíricas corroboram as discussões teóricas a respeito das barreiras enfrentadas pela criança com deficiência no que se refere às oportunidades para brincar (CARVALHO, 1998), e ratificam a importância da brincadeira para o desenvolvimento da criança com paralisia cerebral, visto que o oferecimento de oportunidades para brincar favoreceu a melhora da coordenação motora, da cognição, da linguagem, da socialização, da atenção e do equilíbrio, dentre outros (LORENZINI, 1999; PERES, 2004; SPARLING; WALKER; SINGDAHLSEN, 1984). O estudo de Sparling, Walker e Singdahlsen (1984) também confirma as discussões de Ferland $(2005,2006)$ sobre a possibilidade de se produzir uma melhora nas habilidades funcionais por meio do desenvolvimento das habilidades para brincar, visto que os autores observaram uma melhora no desempenho de atividades da vida diária após o programa de brincadeiras.

A pesquisa descrita por Ferland (2005, 2006) possibilita-nos perceber que a incapacidade física, embora possa limitar a ação, não impede o desenvolvimento de uma maneira de ser, de uma atitude. De maneira similar, Blanche (2002) defende que a criança com seqüelas de paralisia cerebral, a despeito das barreiras por ela enfrentadas, tem motivação interna para participar de diferentes tipos de brincadeiras.

O interesse das crianças pelas brincadeiras, bem como a opinião dos adultos com deficiência (FERLAND, 2006), chama a atenção para a necessidade de repensarmos o uso da brincadeira na terapia ocupacional. Esta necessidade também está expressa na fala dos pais, visto que estes encaram a brincadeira das crianças com deficiência como exercício para desenvolver habilidades, não percebendo o valor da brincadeira livre para o desenvolvimento de seus filhos. Blanche (2002) também afirma que a atenção dos terapeutas, sempre voltada para as limitações físicas, faz com que os pais negligenciem outras facetas da criança com deficiência, inclusive a sua necessidade de realizar atividades lúdicas, tal como qualquer criança. 


\subsection{A atividade lúdica e a Terapia Ocupacional}

Na terapia ocupacional, o homem é “[...] percebido como um ser biopsicossocial, movido pela necessidade fundamental de atuar em seu ambiente: a atividade significativa dá um sentido a este agir e favorece a adaptação ao longo da vida” (FERLAND, 2006, p. XIV). Assim, sendo a brincadeira a atividade mais significativa da criança, ela pode ser vista como uma modalidade terapêutica e como território de intervenção do terapeuta ocupacional.

De acordo com Blanche (2002) e Ferland (2006), a brincadeira pode ser utilizada pelo terapeuta ocupacional de diferentes maneiras, o que depende do enfoque e do referencial teórico por ele utilizado. Ferland (2006), na pesquisa realizada com terapeutas ocupacionais canadenses, observou que, na maioria das vezes, a brincadeira é utilizada em seu aspecto instrumental; o terapeuta planeja antecipadamente e dirige as sessões, dando pouco espaço à liberdade da criança. Neste caso, a brincadeira é um dentre vários instrumentos, sendo utilizada para avaliar funções, para atingir objetivos terapêuticos, para desenvolver habilidades motoras e perceptivas, para suscitar o interesse da criança, para fornecer uma recompensa por um bom comportamento ou para preparar a criança para a vida adulta.

Neste mesmo enfoque, Erhardt e Merrill (2002); Meyerhof e Prado (1998) e Motta e Takatori (2001) salientam que os brinquedos podem ser usados no tratamento para estimular determinadas habilidades (cognitivas, motoras, sociais), fazendo-se necessário o uso de atividades escolhidas e dirigidas pelo terapeuta. Contudo, ser escolhida previamente, ser externamente controlada e ser orientada para um objetivo são características deste tipo de atividade que entram em conflito com a essência da atividade lúdica (BLANCHE, 2002).

Se considerarmos que o que determina a brincadeira é a atitude que o sujeito estabelece durante a atividade, o simples fato de manusear um brinquedo não significa que a criança esteja 
brincando (BOMTEMPO, 1987; DANTAS 2002; FERLAND, 2006; KISHIMOTO, 1996;

PRADO, 1991). Assim, o uso de materiais escolhidos pelo terapeuta para desenvolver alguma função específica pode ou não ser considerado brincadeira pela criança (BLANCHE, 2002). De acordo com Ferland (2006), se a criança só faz a atividade de brincar imposta pelo adulto, faz a ação sem a atitude, portanto, não é mais brincadeira. Pode haver atividade lúdica sem ação, mas não atividade lúdica sem atitude lúdica.

Portanto, a mesma dialética encontrada na área da educação sobre a distinção entre atividade lúdica e atividade pedagógica pode ser transposta para o campo da Terapia Ocupacional, na distinção entre atividade lúdica e atividade terapêutica, fazendo-nos pensar que, o que frequentemente chamamos de brincadeira pode ser, na verdade, exercício, atividade terapêutica ou atividade pedagógica. Bruner (1986) também salienta que, ao se fazer o uso da brincadeira na terapia ou no ambiente escolar, deve-se tomar cuidado para que não ocorra a manipulação e o confisco da iniciativa da criança.

Segundo Dantas (2002), o que se vê na prática é que muitos professores impõem atividades que eles julgam prazerosas, retirando da criança a possibilidade de escolha. Mas atividade obrigatória não é brincadeira, é trabalho. Contudo, se nos contentarmos em empregar a palavra liberdade

[...] com o sentido de alguma possibilidade de escolha, teremos que nos referir a graus de liberdade que começam com a possibilidade de recusar o convite do adulto, e se ampliam na medida em que se multiplicam as alternativas de atividade. Em uma sala vazia, uma criança não pode exercer atividade livre; sua liberdade cresce na medida em que lhe são oferecidas possibilidade de ação, isto é, opções (DANTAS, 2002, p. 112).

Assim, para esta autora, a garantia da liberdade da criança não implica na demissão do adulto: pelo contrário, expandir a liberdade da criança implica no aumento das ofertas adequadas às suas competências em cada momento do desenvolvimento. 
No caso da criança com deficiência, este tipo de discussão se torna ainda mais importante, devido ao fato de que esta criança, com freqüência, encontra diversas limitações para a realização de brincadeiras espontâneas.

Para Missiuna e Pollock (1991), se considerarmos o brincar como a atividade primária da criança e a brincadeira livre como essencial para o seu desenvolvimento, então o incremento de habilidades para o brincar se torna um objetivo importante da intervenção terapêutica. Ou seja, assim como se faz necessário, muitas vezes, o desenvolvimento de adaptações ou a utilização de recursos técnicos para que a criança com deficiência adquira maior independência para a realização de suas atividades de vida diária e escolares, também podem ser necessárias estas intervenções técnicas para que ela consiga brincar com maior independência. Neste caso, a atividade lúdica deixa de ser um instrumento de atuação do terapeuta ocupacional e passa a ser o objetivo de sua intervenção, “[...] não apenas um meio para um fim, mas também como um fim em si mesmo” (BLANCHE, 2002, p. 216).

Jurdi (2001, p. 47) também salienta que a atividade lúdica é importante “[...] não apenas como recurso terapêutico, mas como catalisador de um espaço de trocas e transformações”, pois permite à criança com deficiência “[...] a alteração de um estado de 'ser deficiente’ para um espaço de ‘ser criança”” (grifos da autora).

Ao possibilitar que a criança com deficiência consiga brincar da maneira mais livre e satisfatória possível, o terapeuta ocupacional tem um papel importante na prevenção de incapacidades secundárias que podem surgir como resultado da privação do brincar (MISSIUNA; POLLOCK, 1991). Quando o brincar é tido como um fim em si mesmo, sendo incorporado tanto ao tratamento quanto à vida cotidiana da criança, seus componentes básicos podem ser desenvolvidos, pois a brincadeira por si só possibilita: experimentar o prazer e a diversão; desenvolver a iniciativa para iniciar, mudar e terminar uma atividade; aprender a agir e se 
comportar de maneira mais flexível; desenvolver motivação intrínseca para participar do processo de tomada de decisões; desenvolver habilidades para controlar o ambiente e para suspender a realidade; estimular a criatividade; favorecer a participação ativa e o nível de atenção, o que afeta a aprendizagem, o desempenho geral e a interação com o ambiente (BLANCHE, 2002; FERLAND, 2006).

Além dos benefícios decorrentes da brincadeira por si só, o terapeuta também pode incluir, na atividade lúdica, alguns elementos que favoreçam o desenvolvimento de alguma habilidade específica. Neste caso, a brincadeira passa a ser, ao mesmo tempo, o objetivo e o instrumento da intervenção do terapeuta. De maneira diferente da primeira abordagem mencionada (a atividade lúdica com instrumento terapêutico), esta abordagem é centrada na criança, estimulando sua participação ativa na terapia (FERLAND, 2006).

Ferland (2005, 2006) sistematizou esta proposta de intervenção, dando-lhe o nome de Modelo Lúdico, o qual apresenta alguns princípios básicos. Primeiramente, a criança é dona de sua terapia, sendo ela quem decide a brincadeira, visto que o processo de decisão é parte integrante do tratamento, desenvolvendo sua autonomia e dando-lhe um sentimento de controle e satisfação. O outro princípio é decorrente deste primeiro, pois o terapeuta deve se adaptar e adaptar seus objetivos terapêuticos à escolha da criança. Para isso, o terapeuta se utiliza da análise de atividades, para analisar rapidamente a situação da brincadeira, refletindo sobre a ação, verificando possibilidades de intervir e acompanhando o desenvolvimento da criança. Por outro lado, a terapia deve ser iniciada desde a chegada da criança, estimulando sua postura ativa, exploratória e participativa, e não apenas quando começa a brincadeira, pois todas as situações podem ser fontes de trabalho terapêutico, cabendo ao terapeuta analisar a situação para retirar dela o seu potencial terapêutico. 
Nesta abordagem, o terapeuta não deve ser um observador passivo, mas deve participar da brincadeira, demonstrando atitude lúdica e favorecendo o desenvolvimento da criança. Para isso, deve estimular a criança a tomar decisões e encontrar soluções, assim como sugerir maneiras de brincar que enriqueçam a sua experiência lúdica. Embora não deva evitar as frustrações, visto que isto faz parte do desenvolvimento de qualquer criança, o terapeuta pode também ajudá-la quando necessário, colocando a seu serviço os meios de que dispõe, tais como adaptações e manuseios, que devem ser empregados com sutileza e de maneira lúdica. A autora indica que pode ser necessária uma participação mais ativa do terapeuta nas brincadeiras com crianças com deficiência mental, visando estimular o seu envolvimento e manter o seu interesse.

De maneira geral, no início de cada atendimento, o terapeuta ocupacional pode sugerir alguns brinquedos que estejam disponíveis e a criança escolhe a brincadeira que lhe atrair. O brinquedo deve ser oferecido pelo seu potencial lúdico e pelo interesse da criança, não em função de suas limitações. Mas também podem ser utilizadas brincadeiras adaptadas, permitindo às crianças gravemente comprometidas o sentimento de controlar o ambiente.

Segundo Ferland (2006), os objetivos terapêuticos envolvem a ação da brincadeira (desenvolvendo as habilidades sensoriais, motoras, cognitivas e sociais), a atitude lúdica (redescobrindo o sentido do brincar) e o interesse da criança pelas brincadeiras (aumentando seu repertório de interesses). Além destes objetivos gerais, podem ser acrescentados à brincadeira outros personagens ou situações que estimulem alguma habilidade específica.

Quanto às habilidades motoras, a autora salienta que, na brincadeira, a criança manipula espontaneamente objetos de diferentes formas e tamanhos, planeja gestos, desenvolve o controle motor, desloca-se, mantém o equilíbrio, etc. Assim, ao brincar, a criança trabalha constantemente sua função física, mas o faz sem se dar conta. “Uma vez que a motivação é para brincar e não 
para executar um gesto motor, ela terá mais prazer em agir com objetos, repetirá com mais prazer sua ação e integrará de maneira mais eficaz o esquema motor” (FERLAND, 2006, p. 97).

Para a autora, o brincar é uma modalidade terapêutica completa em si, que favorece o desenvolvimento das atitudes e das habilidades, mas pode ser conciliado com outras técnicas terapêuticas que buscam reduzir as limitações impostas pela deficiência.

Embora o Modelo Lúdico ofereça uma estruturação do uso da brincadeira como objetivo e instrumento da intervenção do terapeuta ocupacional, Ferland (2006) afirma que o modelo não é totalmente inédito, visto que muitos profissionais aplicam intuitivamente métodos semelhantes ao apresentado.

De fato, outros autores também mencionam alguns aspectos semelhantes aos encontrados no Modelo Lúdico, tais como Blanche (2002), que defende que o terapeuta deve seguir a liderança da criança e deve acreditar em suas próprias habilidades de lidar com o processo da terapia, sem seguir um plano estruturado previamente à chegada da criança.

Para esta autora, “uma sessão de tratamento pode ser transformada em recreação quando se permite que a criança escolha uma atividade, seja espontânea e se divirta” (BLANCHE, 2002, p. 210). A criança pode ser convidada a entrar em um mundo no qual a realidade seja suspensa por algum tempo e o objetivo da atividade seja apenas a sua realização. Mesmo que tenha o objetivo de trabalhar alguma função específica, o terapeuta pode aumentar a probabilidade da participação da criança se levar em conta a percepção que esta tem da brincadeira. Assim, os brinquedos utilizados devem ser baseados tanto nos objetivos do terapeuta quanto na motivação e nos interesses da criança. Desta forma, o terapeuta não deve se preocupar em ter muito controle sobre a situação. Durante a atividade escolhida pela criança, o terapeuta pode estimular movimentos ativos e a exploração, enquanto a criança pode desenvolver capacidades de resolução de problemas e praticar as habilidades recentemente adquiridas. 
Blanche (2002) afirma ainda que, dependendo dos objetivos do terapeuta e das necessidades da criança, este pode desempenhar diferentes papéis: aquele que provê o espaço e o tempo para a brincadeira, aquele que medeia a relação entre as crianças ou medeia a resolução de problemas durante a tarefa, aquele que assume um papel muito ativo e dirige a brincadeira, aquele que observa a atividade ou aquele que brinca com a criança. Neste último caso, o adulto e a criança podem agir como companheiros iguais, revezando-se durante a interação.

Zerbinato, Makita e Zerloti (2003) parecem defender este último papel, ao afirmar que, embora o terapeuta deva ter claros os objetivos do tratamento, a escolha do brinquedo pode ser da criança e o terapeuta não precisa ter medo de brincar com ela. Takatori (1999) também fala da importância de que o terapeuta seja um companheiro de brincadeira da criança.

Uma outra função frequentemente atribuída ao terapeuta ocupacional é a adaptação dos brinquedos às possibilidades da criança. Para Erhardt e Merrill (2002), as habilidades de analisar as atividades que o terapeuta ocupacional possui podem ser utilizadas para adaptar o tamanho, a forma e a consistência dos materiais, bem como as regras e procedimentos da brincadeira, a posição da criança e o grau de interação com outros participantes.

Blanche (2002) também fala da importância da escolha de brinquedos adequados, principalmente para a criança com comprometimentos severos, ressaltando que pode haver a necessidade de adaptar os materiais para responder às necessidades da criança. A autora dá algumas dicas quanto à seleção dos materiais, de modo que as crianças com tônus flutuante podem se beneficiar de brinquedos mais pesados ou que ofereçam resistência, pois facilitam a estabilidade proximal e o feedback sensorial; já as crianças com hipertonia, podem ter mais facilidade para manusear brinquedos mais leves. Os brinquedos que requerem menores capacidades de manipulação são adequados para a maioria das crianças, assim como os 
brinquedos que não têm regras rígidas quanto a sua utilização, pois permitem maior flexibilidade, aumentam a motivação de participar e favorecem o sentimento de controle sobre o material.

Para Zerbinato, Makita e Zerloti (2003), a criança com seqüelas de paralisia cerebral, por conta de suas incapacidades motoras, pode necessitar de ajuda para descobrir e aprender. Esta autora também salienta a importância da análise das propriedades e características do brinquedo, para que este possa ser adaptado à capacidade individual da criança. Contudo, os brinquedos também precisam oferecer desafios adequados, pertinentes à fase de desenvolvimento, instigando a criança à resolução dos problemas, superando gradativamente os obstáculos. Além disso, os terapeutas devem dar dicas aos pais sobre como facilitar o brincar, ressaltando a importância de fazer “com” a criança, não “pela” criança.

Para Ferland (2006, p. 61), se, ao utilizarmos a brincadeira, “[...] fazemos a criança descobrir o prazer da ação, se conseguimos desenvolver uma atitude lúdica, usar suas forças para compensar suas fraquezas, contribuiremos para assegurar-lhe um cotidiano mais satisfatório”, melhorando o seu presente, não pensando apenas em seu futuro.

\subsection{A atividade lúdica e a relação adulto/criança}

De acordo com Blanche (2002), o adulto deve ver a si mesmo como uma ferramenta que pode facilitar ou inibir a brincadeira da criança com deficiência, tanto no tratamento quanto na vida cotidiana. Deste modo, faz-se necessário refletir sobre o papel do adulto (seja ele terapeuta, professor, pai, mãe, irmão, entre outros) na facilitação da brincadeira das crianças com deficiência. 
Para Pierri e Kudo (1994, p. 247)

Cabe ao adulto valorizar e promover a atividade de brincar das crianças, seja através da garantia de tempo e espaço para que ela aconteça ou seja através da providência de materiais e brinquedos que facilitem este brincar. O momento e espaço do brincar devem ser respeitados e reconhecidos como fundamentais para o desenvolvimento da criança.

Da mesma forma, para Prado (1991, p. 161),

O adulto é o parceiro principal de interação com a criança e é quem, entre outras funções, vai lhe explicitando os significados embutidos nas relações humanas, nos objetos e palavras. Ele tem ainda papel importante na organização, a nível concreto, dos espaços lúdicos de que a criança disporá para estabelecer novas interações.

Bruner (1986) também destaca o papel do adulto como mediador da atividade lúdica da criança, sendo sua função auxiliar na solução de problemas e na criação de situações que possam enriquecer o jogo.

Bruner (1996) também menciona a importância da relação de tutela, que consiste essencialmente em um tipo de proteção, de modo que o adulto/especialista toma em suas mãos aqueles elementos da tarefa que excedem inicialmente as capacidades da criança/novato, permitindo-lhe concentrar seus esforços sobre os elementos que estão sob seu domínio de competências, possibilitando o desenvolvimento destas. Este autor também salienta a importância da interação adulto/criança ao discutir a aprendizagem e o desenvolvimento da criança, fazendo referência à teoria de Vygotsky, que defende que o adulto deve preparar a atividade, permitindo que a criança avance no seu desenvolvimento. Segundo Kishimoto (2002, p. 145) "Bruner entende supervisão como um sistema de trocas interativas. [...] Embora valorize a ação livre e iniciada pela criança, a exploração requer ambiente que propicie estímulo e orientação”. 
Braga (1995), ao discutir o desenvolvimento da criança com problemas neurológicos sem alterações cognitivas primárias, toma a teoria de Von Cranach e Valach $(1984)^{15}$, que define a ação como um comportamento humano consciente e propositalmente direcionado para um objetivo, não a relacionando ao contato motor ou tátil com o objeto. Para os autores, “[...] a ação depende do pré-estabelecimento de um plano, de um planejamento, ao mesmo tempo em que é continuamente desenvolvida e ajustada considerando as circunstâncias sociais”. A partir deste pressuposto, a autora defende que é possível, mesmo para a criança com graves comprometimentos motores, desempenhar um papel ativo no seu desenvolvimento, se lhe dermos a possibilidade de “[...] planejar a sua ação e executá-la através da mediação de outra pessoa, no caso das ações que implicam, obrigatoriamente, movimento ou contato físico com o objeto” (BRAGA, 1995, p. 55).

Diante desta colocação e das discussões sobre a relação de tutela, podemos pensar que uma outra pessoa pode ser mediadora para a ação concreta da criança com graves comprometimentos motores, ou seja, o outro pode dirigir seus movimentos para a manipulação de objetos, permitindo, porém, sua contribuição ativa na tarefa, manifestando suas intenções e objetivos, bem como escolhendo os meios a serem utilizados.

Neste sentido, a valorização do papel do adulto como mediador e como tutor da atividade da criança é uma contribuição importante para a reflexão acerca da criança com deficiência que, freqüentemente, necessita de um maior suporte para a realização de atividades habituais. O adulto pode, assim, servir de apoio, ajudando a criança a realizar as ações de que ainda não é capaz, tornando possível para ela a participação naquelas ações que já domina. Não se pode esquecer,

\footnotetext{
${ }^{15}$ VON CRANACH, M.; VALACH, L. The social dimension of goal-directed action. In: TAJFEL, H. (org.). The social dimension. Cambridge: Cambridge University Press, 1984.
} 
porém, que o objetivo da relação de tutela é possibilitar o desenvolvimento do aprendiz, permitindo-lhe, gradualmente, adquirir maior autonomia na realização de suas tarefas.

Assim, quando a criança com deficiência física conta com o suporte do adulto para a realização de atividades nas quais encontre dificuldades, tornando possível para ela a ação sobre o ambiente e participação em diversos tipos de brincadeiras, é possível prevenir a ocorrência de incapacidades secundárias, bem como favorecer o seu desenvolvimento integral. 


\section{CAPÍTULO 3}

\section{OS CONCEITOS}

\subsection{Teorias sobre a formação de conceitos}

De modo geral, conceitos têm sido considerados como representações mentais de objetos, pessoas e eventos, reais ou imaginários, constituindo-se num tipo de agrupamento cognitivo. Segundo Lomônaco (1997, p. 11), podemos dizer que o indivíduo tem um conceito, “[...] quando ele formou uma representação mental capaz de abranger todos os exemplos da categoria”. Enquanto o termo conceito refere-se à representação mental, ao significado, os termos categoria e classe referem-se ao conjunto de exemplos que são abrangidos pelo conceito, ou seja, a todos aqueles elementos que são por ele representados.

Embora haja uma razoável concordância entre os estudiosos no tocante aos aspectos acima considerados, não existe unanimidade entre eles quanto à definição de conceito. Flavell $\left(1976^{16}\right.$ apud LOMÔNACO, 1997) salienta que uma das dificuldades em se estabelecer precisamente uma definição de conceitos é o fato de que um número muito grande de entidades pode ser incluído sob esta noção. Além disso, os conceitos podem diferir em muitos aspectos, tanto no que diz respeito aos atributos de que são compostos, quanto no que se refere à sua estrutura, grau de abstração (variando desde conceitos totalmente concretos a altamente abstratos) e grau de generalidade (dependendo da posição que ocupam em uma classificação hierárquica).

Provavelmente em função de seu valor adaptativo, o ser humano desenvolveu, desde muito cedo, a capacidade de categorizar ou de formar conceitos (LOMÔNACO, 1997). Bruner,

\footnotetext{
${ }^{16}$ FLAVELL, J.F. O desenvolvimento de conceitos. In: MUSSEN, P.H. (org). Carmichael Psicologia da Criança. São Paulo: EPU/EDUSP, 1976. v. VI, p. 1-13.
} 
Goodnow e Austin (1956/1967) afirmam que os conceitos desempenham vários papéis no funcionamento cognitivo do ser humano: a) reduzem a complexidade do ambiente, possibilitando-nos tratar as coisas, não como particulares, mas como pertencentes a grupos; b) permitem a identificação dos objetos, eventos e pessoas que nos circundam; c) reduzem a necessidade de aprendizagem constante, pois, uma vez formado um conceito de algo, não precisaremos reaprendê-lo cada vez que entrarmos em contato com um novo exemplo deste algo; d) dirigem nossa atividade instrumental, pois atuamos no mundo de acordo com os conceitos que formamos (por exemplo, agiremos diferentemente diante de um cão que conceituamos como “bravo” ou como “manso”).

Assim sendo, o estudo da formação de conceitos é fundamental para a compreensão de nossa vida mental e de nossos processos cognitivos. Por isso, o interesse pelo assunto tem sido marcante e permanente, tanto na Filosofia, remontando-se, na Grécia Antiga, às especulações de filósofos como Sócrates, Platão e Aristóteles, quanto na Psicologia (LOMÔNACO, 1997; OLIVEIRA, 1994).

Na Psicologia, estudos empíricos sobre o tema começaram a ser realizados desde a década de 20 do século passado, por Clark L. Hull ${ }^{17}$, dentro do referencial filosófico do realismo aristotélico $^{18}$, e da teoria psicológica do behaviorismo, desenvolvendo-se uma tradição de estudo e pesquisa que veio, posteriormente (a partir da década de 70 do século passado), a ser denominada de visão clássica $^{19}$. De acordo com essa visão, os conceitos são formados por meio

\footnotetext{
${ }^{17}$ HULL, C.L. Quantitative aspects of the evolution of concepts. Psychological Monographs, v. 28, n. 123, 1920.

${ }^{18}$ Para Aristóteles, as coisas do mundo possuem essências, contudo estas essências não são percebidas pelos sentidos, mas pela razão. Para apreendermos a essência de algo, utilizamos o processo de abstração, que consiste em isolar/separar algumas de suas características do contexto global. Assim, para apreendermos a essência das flores, por exemplo, precisamos abstrair o que é universal a todas elas. Ao abstrairmos o que é universal, o que é essencial, formamos o conceito flor.

${ }^{19}$ O termo "visão" é utilizado comumente nos estudos sobre conceitos como sinônimo de “concepção teórica”. Segundo Lomônaco (1997), Smith e Medin, em um livro publicado em 1981 e intitulado Categories and Concepts, foram quem primeiramente empregaram o termo, ao rotular a mais antiga das concepções teóricas sobre conceitos
} 
da abstração de atributos comuns a algumas coisas no mundo e não comuns a outras coisas, permitindo-nos fazer um recorte da realidade e constituir uma categoria (LOMÔNACO, 1997).

Um sujeito, por exemplo, entra em contato, ao longo de sua vida, com uma grande variedade e diversidade de livros e, gradualmente, vai percebendo algumas diferenças e algumas similaridades entre eles. O processo de abstração consiste em desconsiderar as características que variam de um livro para o outro, tais como a cor e o tamanho, e isolar os atributos que estão presentes em todos os livros, tais como impressão de letras do alfabeto, conteúdo agrupado, autoria, título, etc. A partir desses atributos, o sujeito forma uma representação mental que possibilita o reconhecimento e a inclusão de novos membros na categoria, numa base de tudo-ounada: qualquer objeto que apresente estas características será necessariamente um livro; se um objeto não apresentar qualquer atributo que faça parte da representação, ele não será considerado um exemplo desta categoria. Assim, na visão clássica, “as características que representam um conceito são individualmente necessárias e conjuntamente suficientes para defini-lo" (LOMÔNACO et al., 1996, p. 52).

Portanto, a representação de um conceito consiste numa descrição sumária de toda uma classe, pois agrupa as características partilhadas por todos os seus exemplos e subconjuntos. Por ser uma representação sumária, ela não corresponde a nenhum exemplo específico, mas aplica-se a todos os exemplos possíveis daquela classe.

De acordo com a visão clássica, os conceitos se organizam segundo o seu grau de generalidade. Por exemplo, o conceito de ser vivo é mais geral que os conceitos de animal e vegetal; por sua vez, o conceito de animal engloba animais vertebrados e invertebrados; dentre os animais vertebrados, podemos citar cães, gatos, homens, etc. Desta forma, nossos conceitos se

com o nome de visão clássica. Esta expressão foi gradativamente adotada pelos estudiosos, tornando-se atualmente consagrada na área. 
organizam num sistema hierárquico de inter-relações, no qual os conceitos mais específicos devem necessariamente apresentar todas as características dos conceitos mais gerais que os englobam (o conceito de cão, por exemplo, deve conter todas as características dos conceitos de animal vertebrado, animal e ser vivo) (TOLENTINO et al., 1986).

Da visão clássica decorrem algumas implicações necessárias: uma vez que todos os exemplos possuem os mesmos atributos comuns, não existem exemplos mais ou menos representativos do conceito, todos apresentam a mesma representatividade (por exemplo, cão e ornitorrinco representam igualmente bem a categoria de animal); visto que a inclusão de novos exemplos na categoria é feita na base do tudo-ou-nada, não existem casos limites ou duvidosos, sendo os limites das categorias muito bem definidos (não haveria dúvidas, por exemplo, quanto à inclusão dos cintos na categoria de vestuário ou de acessórios) (LOMÔNACO, 1997).

Até a década de 60 do século passado, a visão clássica era tida como um pressuposto auto-evidente, não sendo questionada, mas aceita naturalmente (LOMÔNACO, 1997; OLIVEIRA, 1994). Porém, a partir da década de 70, algumas de suas limitações passaram a ser explicitadas e criticadas.

Uma destas limitações diz respeito à impossibilidade de se especificar as propriedades que definem grande número de nossos conceitos. Deste modo, embora a visão clássica tenha como pressuposto que todos os conceitos têm atributos definidores, se tentarmos identificar os atributos definidores de, por exemplo, um cão, sentiremos uma enorme dificuldade em especificar as características essenciais de todos os seus exemplares, pois, mesmo que um cão deixe de ter quatro patas, perca os pêlos e deixe de latir, continuará sendo um cão. Como podemos deduzir a partir deste exemplo, nenhuma característica, isolada ou conjuntamente, parece ser necessária e suficiente para definir um cão. 
Uma outra limitação da visão clássica diz respeito à diferente representatividade dos exemplos que compõem uma categoria. Intuitivamente percebemos que uma maçã parece mais representativa da categoria de fruta do que uma jaca ou um tamarindo. Ou, como no exemplo anterior, um cão parece mais representativo da categoria animal do que um ornitorrinco ou um gambá. Uma terceira limitação: embora os pressupostos da visão clássica impliquem em aceitar que os limites das categorias são bem delimitados, na prática percebemos que, em muitos casos, temos dificuldades em decidir se um elemento faz parte ou não de uma categoria. Por exemplo, temos dificuldades em determinar se os patins devem ser incluídos na categoria de brinquedo ou de meios de transporte, bem como podemos ter dúvidas quanto à inclusão dos cintos na categoria de roupa ou de acessórios (LOMÔNACO, 1997).

Essas e outras críticas colocaram a visão clássica seriamente em questão e propiciaram o surgimento de duas novas teorias, que procuraram responder às dificuldades consideradas. Uma destas teorias ficou conhecida como visão prototípica ou probabilística. Segundo ela, os conceitos são formados a partir da abstração dos atributos que aparecem com maior freqüência nos exemplos da categoria, negando a existência de elementos definidores presentes em todos os exemplos. Se utilizarmos o exemplo mencionado anteriormente quanto à formação do conceito de livro, perceberemos que este processo e seu resultado seriam diferentes na concepção prototípica. Ou seja, com base nesta visão, ao entrar em contato com muitos exemplos de livros, o sujeito irá abstrair as características que aparecem com maior freqüência, mas que não estão necessariamente presentes em todos os exemplos de livros (por exemplo, o formato retangular, a capa mole ou as páginas de cor branca). A partir destas características mais freqüentes, o sujeito formará uma representação mental, denominada de protótipo, que constitui o conceito de livro. Da mesma forma que na visão clássica, o protótipo de livro também não corresponde a nenhum livro específico, sendo uma representação mental sumária da categoria. Uma vez formado, o 
protótipo será utilizado para a inclusão ou exclusão de novos exemplos na categoria, com base na semelhança desses em relação ao protótipo (LOMÔNACO et al., 2001).

A suposição central à visão prototípica é a de que os atributos ou características dos objetos não se distribuem de forma aleatória no mundo real, mas apresentam-se correlacionados, de modo que nossos protótipos não se formam de maneira arbitrária. Assim, por exemplo, a presença de pêlos, do latido e de quatro patas é mais comum entre os cães do que a ausência destas características. Por isso, o indivíduo, sensível à freqüência com a qual estas características aparecem nos exemplos de cães, abstrai estes atributos. Desta forma, a visão prototípica substitui a noção de atributos definidores pela noção de atributos característicos, entendo-se por característicos aqueles atributos que têm maior probabilidade de ocorrer nos exemplos dos conceitos.

Visto que o protótipo pode variar dependendo dos exemplos com os quais os sujeitos entraram em contato, uma pessoa pode ter um protótipo de livro ou de cão diferente do protótipo formado por outra pessoa. Neste aspecto, a visão prototípica difere profundamente da visão clássica, para a qual os conceitos, se formados adequadamente, devem ser iguais para todas as pessoas.

A visão prototípica tem condições de responder a algumas limitações da visão clássica. Ela consegue explicar, por exemplo, porque temos dificuldade em determinar a qual categoria pertencem alguns objetos. Para a visão prototípica, os limites de algumas categorias são imprecisos e mal definidos, pois alguns exemplos podem ter poucas características em comum com o protótipo, estando mais afastados dele, ou um mesmo objeto pode partilhar de características com mais de um protótipo, como é o caso dos patins, que possuem características tanto de brinquedos quanto de meios de transporte. Além disso, visto que a inclusão de novos exemplos na categoria é feita com base na semelhança destes em relação ao protótipo, um 
exemplo mais semelhante (que partilhar de maior número de características em relação ao protótipo), será mais facilmente categorizado, sendo este um exemplo mais representativo da categoria do que outros exemplos menos semelhantes ao protótipo. Por isso, uma maçã pode representar melhor a categoria de fruta do que uma jaca ou um tamarindo, pois a maçã se assemelha mais ao protótipo de fruta.

A outra teoria, menos influente que as duas anteriormente citadas, é conhecida como visão dos exemplares. Segundo ela, os conceitos são representados por exemplos específicos da categoria, e não por uma definição ou por um protótipo formado pela abstração dos elementos presentes nos exemplos. Ou seja, o conceito de livro não seria formado por meio da abstração de atributos definidores ou dos atributos mais freqüentemente presentes nos exemplos de livro com os quais o sujeito entrou em contato. Ao invés disso, o sujeito elegeria um ou mais exemplos específicos de livro para representar seu conceito (por exemplo, aquele livro verde e de capa dura da biblioteca e/ou seu primeiro livro de histórias infantis). Uma vez escolhido(s) o(s) exemplar (es), o sujeito decidiria, então, quanto à inclusão ou não de novos exemplos na categoria, com base na semelhança destes em relação ao(s) exemplo(s) específico(s) que representa(m) seu conceito.

Embora respondam a algumas das limitações da visão clássica, a visão prototípica e a visão dos exemplares também receberam muitas críticas, sendo suas limitações apresentadas a partir da década de 80 do século passado. A mais séria destas limitações é o fato destas teorias basearem suas explicações da coesão conceitual somente na noção de similaridade. Coesão conceitual é o que mantém agrupados os elementos que constituem uma categoria, que responde à pergunta referente ao porque temos os conceitos que temos e não outros, ou porque algumas categorias nos parecem lógicas e com sentido, enquanto outras nos parecem totalmente arbitrárias (por exemplo, parece-nos lógico agrupar laranjas e maçãs, contudo, não nos parece razoável 
incluir caderno e geladeira em uma mesma categoria). As três teorias de conceitos consideradas anteriormente apelam para o fator similaridade na explicação deste processo, como se os objetos, entidades ou eventos formassem conceitos simplesmente por partilharem de aspectos comuns. $\mathrm{Na}$ visão clássica, a similaridade está relacionada ao compartilhamento de atributos comuns entre todos os membros de uma categoria. Na visão prototípica e na visão dos exemplares, diz respeito à semelhança entre um novo elemento e o protótipo ou exemplar que representa o conceito, respectivamente (LOMÔNACO et al., 1996; LOMÔNACO et al., 2001; MURPHY; MEDIN, 1985).

Entretanto, de acordo com Medin (1989) e Murphy e Medin (1985), a similaridade parece ser muito flexível para explicar a coesão conceitual, visto que, se não for determinado o que deve ser levado em consideração nas análises de similaridade, qualquer elemento pode ser considerado similar a outros em vários aspectos. Os autores mencionam que, se não houver restrições para a similaridade no que diz respeito ao processo de formação de conceitos, ameixas e cortadores de grama (ou, como no exemplo anterior, caderno e geladeira) poderiam ser incluídos sob uma mesma categoria, visto que partilham de inúmeros aspectos comuns, tais como: pesam menos de $1.000 \mathrm{~kg}$, não existiam na pré-história, ocupam lugar no espaço e podem ser vendidos e comprados. Além destas, muitas outras semelhanças poderiam ser arroladas em relação aos objetos citados, entretanto, a despeito de tais semelhanças, estes objetos não formam uma categoria em nenhuma cultura. Assim, a similaridade pode ser um subproduto e não um determinante da coesão conceitual.

Como conseqüência desta e de outras críticas, desenvolveu-se uma nova maneira de considerar os conceitos e explicar a sua formação, a visão teórica. De acordo com esta visão, a coesão conceitual pode ser explicada a partir dos conhecimentos que as pessoas têm do mundo e das coisas ao seu redor, ou seja, a partir das teorias subjacentes aos seus conceitos. Segundo 
Lomônaco (1997) e Oliveira (1994), o termo teoria, neste contexto, não diz respeito apenas às teorias cientificas, mas também às teorias ingênuas, ou seja, aos conhecimentos estabelecidos pelo senso comum.

Deste modo, nossos conceitos não se formam aleatoriamente ou simplesmente com base na semelhança entre os objetos. Quando formamos um conceito, não levamos em conta apenas as características que percebemos nas coisas, mas também os conhecimentos que temos a respeito delas - nossas teorias (KEIL et al., 1998).

Para Oliveira (1994, p. 37), “o princípio básico da concepção teórica [...] é o de que cada conceito deve ser visto como parte da teoria em que se encontra inserido - e de que, na verdade, é elemento constitutivo”. Assim, nesta visão, os conceitos não são mais vistos como entidades isoladas, mas são tidos como intrinsecamente relacionais, pois fazem parte de uma rede de relações. Desta maneira, um conceito não pode ser compreendido se não entendermos como ele se relaciona com outros conceitos, dentro do seu domínio de conhecimentos (KEIL, 1989). De acordo com Lomônaco et al. (2000, pág. 24), “os domínios conceituais são unificados por uma teoria ou conjunto coerente de crenças sobre as relações entre seus conceitos”.

Um outro aspecto peculiar da visão teórica é a maneira pela qual concebe o desenvolvimento de conceitos. De acordo com esta visão, as teorias ingênuas das crianças se desenvolvem e se tornam mais ricas e complexas com a idade. Este desenvolvimento se reflete nos processos de categorização: as crianças mais novas levam em conta as características mais superficiais e prototípicas, aquelas mais diretamente perceptíveis pelos sentidos, mas, com o desenvolvimento cognitivo, passam a dar maior atenção às características menos aparentes e mais essenciais (ou mais clássicas), articulando um conceito com outros a partir das teorias (LOMÔNACO et al., 1996 e 2001; OLIVEIRA, 1994). Por exemplo, as crianças pequenas, conforme demonstrado por Keil (1989) e confirmado por Lomônaco et al. (1996), costumam 
formar o conceito de avó com base em seus atributos característicos (senhora de idade avançada, com cabelos brancos, que gosta de tricotar casacos de lã), mas, à medida que se tornam mais velhas, começam a formar este conceito com base em seus atributos definidores (mãe de sua mãe ou mãe de seu pai).

Contudo, de acordo com Keil et al. (1998), mesmo as crianças pequenas não baseiam seus julgamentos apenas nas relações de similaridade, mas já apresentam algumas teorias ingênuas que guiam o processo de formação de conceitos. Da mesma forma, as crianças mais velhas e os adultos eventualmente fazem uso da similaridade no processo de categorização. Assim, os autores defendem que os conceitos podem ser considerados como entidades híbridas, que possuem um componente associativo, baseado na tabulação de características típicas e nos julgamentos de similaridade, e um componente explicativo, baseado em princípios causais (teorias). Estes componentes podem ter diferentes distribuições dentro de cada conceito, dependendo do seu tipo. Deste modo, os conceitos nominais ${ }^{20}$, que são os mais bem definidos, têm um peso maior do fator associativo, enquanto que os conceitos mais naturais têm a sua estrutura causal mais rica e internalizada.

Visto que um conceito encontra-se relacionado a outros por meio de teorias, uma mudança qualitativa na representação de um conceito leva a uma reorganização do domínio conceitual do qual faz parte. Entretanto, segundo Keil (1989), Lomônaco et al (1996) e Oliveira (1994), estas mudanças qualitativas no tocante ao conhecimento conceitual não ocorrem de maneira global em uma determinada idade, mas em momentos diferentes para diferentes domínios de conhecimento. Assim, devido à influência da estimulação ambiental, as pessoas

${ }^{20}$ Este autor divide os conceitos em naturais (que existem independentemente da ação do homem e que são governados por leis comuns a elas, tais como cão, areia e rosa), nominais (conceitos desenvolvidos por convenção da sociedade e que podem ser claramente definidos, tais como mentira e avô) e artefatos (subconjunto dos nominais, referindo-se a objetos criados pelo homem, que lhes atribui uma função, tais como cadeira e carro) (KEIL, 1989; LOMÔNACO et al., 1996). 
desenvolvem mais rápida e profundamente alguns domínios do que outros, de modo que, mesmo adultos, que dominam teorias científicas em algumas áreas, podem apresentar teorias ingênuas em outras. Um físico, por exemplo, dominará certamente teorias científicas de sua área, mas poderá apresentar uma biologia ingênua e/ou uma psicologia ingênua.

Embora a visão teórica seja a concepção mais atual sobre a formação de conceitos na Psicologia, ela também não encontra unanimidade entre os pesquisadores da área, de modo que as discussões a respeito de como as teorias são formadas e que forma tomam em nossa mente ainda estão em desenvolvimento. O que alguns autores discutem, atualmente, é que cada uma das visões anteriormente citadas explica uma faceta diferente dos conceitos ou é mais adequada para explicar a formação de um tipo especifico de conceitos (LOMÔNACO, 1997; OLIVEIRA, 1994), não havendo, até o presente, uma teoria suficientemente ampla e concisa, que dê conta de explicar o fenômeno como um todo, e que seja unanimemente aceita pelos estudiosos desta área.

\subsection{Pesquisas sobre a formação de conceitos por crianças com deficiência}

Dado a importância dos conceitos no desenvolvimento cognitivo, muitos estudos vêm sendo realizados sobre a formação de conceitos por crianças de diferentes faixas etárias. Estes estudos englobam diversos fatores envolvidos neste processo, bem como estão vinculados a diferentes concepções teóricas. No decorrer desta pesquisa, foi realizado um levantamento da literatura nacional e internacional acerca do processo de formação de conceitos básicos por crianças com deficiência. Este levantamento, cuja execução será melhor detalhada no Capítulo 5, foi realizado em diversas bases de dados e em bibliotecas de universidades situadas nos estados de São Paulo e Espírito Santo. 
Embora a grande maioria das pesquisas tenha sido feita com crianças sem deficiência, várias delas investigaram o processo de formação de conceitos por sujeitos que apresentam algum tipo de deficiência (deficiência auditiva, deficiência mental, Síndrome de Down, etc.). Poucos pesquisadores, entretanto, procuraram estudar este processo em crianças com seqüelas de paralisia cerebral. No decorrer deste levantamento bibliográfico, foram encontrados alguns relatos de pesquisas sobre o desenvolvimento cognitivo e sobre a brincadeira de crianças com este tipo de deficiência, os quais foram apresentados nos capítulos anteriores. No que se refere, contudo, ao processo de formação de conceitos por sujeitos com paralisia cerebral, foram encontrados apenas dois trabalhos, que serão sucintamente descritos.

Lamônica et al. (2003) avaliaram o índice de reconhecimento semântico em 30 crianças com paralisia cerebral, com idades entre dois anos e sete anos e onze meses. Foram realizadas provas de reconhecimento de figuras e nomeação, nas quais o grupo controle (de crianças sem deficiência) apresentou resultados superiores ao grupo experimental. As crianças com paralisia cerebral tiveram maior dificuldade para reconhecer figuras de objetos não relacionados à vida diária, o que pode ter ocorrido pela falta de possibilidades de vivenciar experiências que não estejam relacionadas ao dia a dia. Também foi observada a influência do comprometimento motor, com as crianças com hemiparesia apresentando melhores resultados do que as com diparesia, seguidas pelo grupo com tetraparesia.

Carabetti, Leme e Prieto (2005), realizaram dois estudos de caso com o objetivo de investigar a formação do conceito de número em pessoas com paralisia cerebral. Foram realizadas provas piagetianas referentes à quantidade, igualdade, seriação, classificação e conservação, em quatro sessões individuais. Os resultados permitiram verificar que, enquanto o participante com quadro motor mais leve e melhor condição econômica ainda não havia construído o conceito de número, o participante com um quadro motor mais extenso e situação 
econômica menos privilegiada, já havia adquirido o conceito avaliado. As autoras discutem que, para este aluno, a dificuldade para manipular objetos e para locomoção não se mostrou fator limitante para a aquisição desta noção, uma vez que a interação verbal no ambiente familiar, a interação com sua mãe, a vivência de brincadeiras infantis e a aprendizagem escolar parecem ter compensado a disfunção.

Enquanto a investigação de Lamônica et al. (2003) indica que o desenvolvimento de conceitos pode apresentar relação com o grau de comprometimento motor, o estudo de Carabetti, Leme e Prieto (2005) sugere que nem mesmo um grave comprometimento é fator impeditivo para o desenvolvimento conceitual. Por outro lado, ambos os estudos sugerem que as experiências cotidianas, ou a restrição destas, parecem exercer fortes influências sobre este processo.

No que se refere ao processo de formação de conceitos por crianças com deficiência mental, autismo ou Síndrome de Down, serão relatados alguns poucos trabalhos que talvez possam ajudar-nos a discutir e/ou interpretar os resultados deste estudo.

Spector (1979), como parte de um programa para identificar crianças com possibilidades de desenvolver dificuldades de aprendizagem, aplicou o Teste de Conceitos Básicos de Boehm (BTBC) em 300 crianças em idade pré-escolar, no estado de Nova Iorque. A autora arrolou alguns fatores como possíveis responsáveis pelos erros das crianças: inabilidade em focar a atenção nas palavras-chave das questões, déficits na percepção espacial, déficits de vocabulário, inabilidade em distinguir entre conceitos similares, dificuldade quanto ao nível de abstração do conceito, pobre memória auditiva para as sentenças, influências sociais e culturais. Para a autora, uma pobre compreensão dos conceitos básicos dificulta a capacidade da criança de receber informações e de comunicar suas idéias.

Scheuer (1993) realizou um estudo com o objetivo de avaliar a produção oral das relações espaciais dentro/fora, em cima/embaixo, frente/atrás e perto/longe. Participaram 18 sujeitos com 
deficiência mental leve, institucionalizados, com idades entre 11 e 15 anos, em fase de escolarização. Constatou-se que os resultados deste grupo foram primários e rudimentares, podendo ser comparados aos de crianças pequenas, que apresentam uma linguagem oral prática, de ações e funções.

Bock (1994) avaliou os efeitos do treinamento de estratégias de categorização na aquisição, manutenção e generalização de habilidades para completar tarefas de classificação por quatro crianças com autismo. Verificou-se que o treinamento resultou numa melhora do desempenho em atividades de classificação treinadas e não treinadas. Três destas crianças apresentaram uma manutenção da melhora após dois meses do término do programa de treinamento.

Penazzo (1994) investigou o papel da ação nos processos de abstração e generalização envolvidos na aprendizagem de conceitos, fundamentado na teoria de Piaget. Pesquisou a formação do conceito de sapato em 15 sujeitos com deficiência mental leve, com idades cronológicas entre 7,6 e 11,7 anos. Constatou que a experiência motora, por meio da ação sobre objetos concretos, associada ao exemplo do conceito que se quer ensinar, facilita o processo de abstração.

Aguiar (2001 ${ }^{21}$, apud AGUIAR, 2004) avaliou a influência do jogo na aprendizagem de conceitos fundamentais para a aprendizagem da leitura e da escrita por sujeitos com deficiência mental considerados alfabetizáveis. Participaram 21 sujeitos, com idades entre oito e 17 anos. Os resultados indicaram a eficiência do jogo para a aprendizagem dos conceitos treinados, verificando-se, porém, uma lentidão na formação de conceitos pelos participantes. O autor

\footnotetext{
${ }^{21}$ AGUIAR, J.S. Significado do jogo no ensino de conceitos para leitura e escrita a deficientes mentais com condições de alfabetização. Revista Iberoamericana de Diagnóstico y Evaluación Psicológica, v. 11, n. 1, p. 131151, 2001.
} 
discute, ainda, que o ensino individualizado, o vínculo afetivo e a ação sobre objetos concretos podem ser importantes para a aprendizagem de crianças com deficiência mental.

O mesmo autor (2004) estudou a influência de um programa de jogos recreativos infantis na aprendizagem de conceitos relevantes para a vida cotidiana, tendo como sujeitos crianças com problemas de aprendizagem. Participaram 15 alunos de uma escola especial, com idades entre 8,7 e 13,9 anos. O autor utilizou o Teste de Conceitos Básicos de Boehm como instrumento de avaliação e como guia para a preparação do programa de jogos. Os resultados confirmaram a eficiência do programa de jogos para a aquisição dos conceitos treinados, bem como de sua generalização para situações de sala de aula.

Lomônaco et al. ${ }^{22}$ avaliaram o domínio de conceitos básicos por 20 crianças com Síndrome de Down (idade média: 13,68) e 31 crianças sem deficiência (idade média: 6,48). Como instrumento de avaliação, utilizaram 18 dentre as 50 questões do Teste de Conceitos Básicos de Boehm. Os resultados indicaram um maior domínio dos conceitos básicos por parte das crianças sem deficiência. As crianças com síndrome demonstraram maior facilidade na aprendizagem de alguns conceitos, tais como debaixo, metade e depois, enquanto que alguns conceitos mostraram-se bastante difíceis, tais como lado direito, frente e sempre. Os autores discutem a influência da estimulação escolar e das experiências cotidianas no desenvolvimento de conceitos, bem como salientam algumas limitações do teste utilizado.

Os estudos realizados por Lomônaco et al. (em fase de conclusão), Scheuer (1993) e Spector (1979) apontam para a ocorrência de um atraso no desenvolvimento de conceitos por crianças com deficiência mental. Por outro lado, Aguiar (2001, apud AGUIAR, 2004), Aguiar (2004), Bock (1994), Penazzo (1994) mostram que a experiência lúdica, o treinamento de

\footnotetext{
${ }^{22}$ LOMÔNACO, J.F.B.; CAZEIRO, A.P.M.; CABRAL, C.;. ULASOWICZ, C.; COTRIN, J. O desenvolvimento de conceitos básicos por crianças com Síndrome de Down. Artigo em fase de conclusão.
} 
estratégias de categorização e a experiência motora, influenciam na formação de conceitos básicos por crianças com deficiência, o que sugere que a falta de oportunidades para vivenciar este tipo de experiência pode influenciar de forma negativa no desenvolvimento cognitivo destas crianças. 


\section{CAPÍTULO 4}

\section{A PERSPECTIVA SÓCIO-HISTÓRICA DE VYGOTSKY}

\subsection{A teoria de Vygotsky: uma breve introdução}

No final do século XIX, a ciência psicológica estava dividida em duas correntes: uma era influenciada pela filosofia naturalista-empirista, defendendo que todo conhecimento era adquirido; a outra era influenciada pela filosofia idealista, defendendo que as faculdades mentais existiam inatamente no psiquismo humano. Vygotsky, baseando-se no materialismo histórico, buscou superar este dualismo, elaborando uma síntese das duas correntes antagônicas, admitindo uma interação e uma determinação mútua entre o indivíduo e o contexto sócio-histórico no qual vive (PALANGANA, 2001).

Deste modo, além de receber influências de outros pesquisadores da época, as idéias de Vygotsky foram fortemente influenciadas pelos pensamentos de Karl Marx e Friedrich Engels. Estes, por sua vez, tiveram como ponto de partida a filosofia alemã, mais precisamente, as idéias antagônicas de Hegel e Feuerbach.

Marx e Engels retomaram a idéia da dialética sistematizada por Hegel, contudo, diferentemente deste, acreditavam que a contradição não ocorre num plano metafísico, do espírito consigo mesmo, mas estabelece-se entre os homens em condições reais, históricas e socialmente determinadas. Assim, defenderam que o movimento da história humana pode ser vinculado à natureza por meio do método dialético, que possui as seguintes leis gerais: 
[...] lei da passagem da quantidade à qualidade e vice-versa, que se refere ao processo de transformação social; a lei da interpenetração dos contrários, que explica a interdependência dos diferentes níveis da realidade, mostrando que as coisas não podem ser compreendidas isoladamente e a lei da negação da negação, que busca explicar a luta dos contrários no movimento propulsor da história (PALANGANA, 2001, p. 111).

Para Marx e Engels, a história humana pressupõe a existência de indivíduos concretos que, ao lutarem pela subsistência, organizam-se em torno do trabalho e estabelecem relações entre si e com a natureza. Desta forma, a vida social e econômica está condicionada ao modo de produção da vida material. A história, contudo, não se dá de forma linear e harmônica, mas se dá por meio de contradições, conflitos e antagonismos, de maneira revolucionária, em saltos, como resultado da ação dos próprios homens; do mesmo modo, a transformação das relações humanas e o desenvolvimento do homem não ocorrem de maneira harmônica e espontânea, nem são impostos de fora, sendo, na verdade, decorrentes de contradições internas, criadas em seu próprio bojo (PALANGANA, 2001).

Enquanto Hegel acreditava que as idéias criam a realidade, Marx e Engels, por influência de Feuerbach, defendiam que é a realidade que determina o pensamento, pois a realidade objetiva existe independentemente do homem.

Assim, por ser o pensamento um reflexo da vida material, as idéias, as representações e a consciência não estão dissociadas da atividade material e das relações estabelecidas entre os homens. Para estes autores, é na vida real que começam a ciência real, a formação de conceitos e o desenvolvimento da personalidade, sendo que “[...] a essência do homem é sua prática social, sua criação, isto é, a construção dos instrumentos através dos quais ele interage com a natureza, desencadeando um processo mútuo de transformação” (PALANGANA, 2001, p. 114). Utilizando instrumentos, o homem modifica a natureza e, ao modificá-la, transforma a si mesmo. Assim, a essência humana não é dada de forma pronta e independente do homem, mas é construída 
ativamente, de modo contínuo e infinito, pelo próprio homem. Por este motivo, não há uma essência humana universal e imutável, sendo esta construída historicamente.

Uma questão central para o materialismo dialético é ver todos os fenômenos como processos em movimento e em mudança, então, a partir disso, Vygotsky estudou os processos psicológicos como contendo uma história, um desenvolvimento. Visto que o desenvolvimento intelectual de um homem está diretamente relacionado à evolução histórica das relações sociais de produção, este desenvolvimento não deve ser estudado a partir do próprio pensamento, mas da atividade de vida real deste homem, de suas relações sociais e de sua atividade prática (PALANGANA, 2001; VYGOTSKY, 1998).

Desta forma, dois aspectos da teoria marxista tiveram grande importância para a teoria de Vygotsky: o aspecto cultural e o aspecto histórico. $\mathrm{O}$ aspecto cultural diz respeito às formas como a sociedade organiza o conhecimento, sendo este conhecimento veiculado por instrumentos físicos e simbólicos (principalmente a linguagem), dos quais a criança deve se apropriar para que possa responder às demandas do ambiente. $\mathrm{O}$ aspecto histórico se refere ao fato de que estes instrumentos foram criados e desenvolvidos ao longo da história social dos homens (PALANGANA, 2001).

O pensamento de Engels também influenciou Vygotsky, ao salientar que não apenas a natureza afeta o homem (visão naturalista), mas o homem também age sobre a natureza, provocando transformações e criando novas condições para a sua existência (visão dialética). Assim, o homem não é apenas um produto passivo de seu meio, mas é também um sujeito ativo que recria o meio, a cultura e a realidade (OLIVEIRA, 1992; PALANGANA, 2001).

Há uma interação entre os planos biológico e cultural (condições sociais), juntamente com a participação ativa do sujeito em seu ambiente, gerando uma configuração única para cada indivíduo, que está em constante transformação (OLIVEIRA, 1992). Deste modo, as funções 
mentais mais complexas se formam a partir das estruturas orgânicas, baseadas na maturação, mas são influenciadas pelas experiências sociais. No início da vida, os fatores biológicos preponderam sobre os sociais, mas, pouco a pouco, o desenvolvimento passa a ser orientado pelas interações com pessoas mais experientes, de forma que “a maturação por si só não é suficiente para explicar a aquisição dos comportamentos especificamente humanos” (PALANGANA, 2001, p. 96). Os processos elementares seriam de origem biológica, enquanto as funções psicológicas superiores, seriam de origem sócio-cultural, sendo que, do entrelaçamento dessas duas linhas, nasce a história do comportamento da criança. Em função das variações históricas e dos contextos sociais, não é possível admitir um esquema universal para o desenvolvimento humano (AMORIM, 1997; VYGOTSKY, 1998).

Vygotsky (1998) criticava as posições teóricas da época que consideravam que o desenvolvimento e o aprendizado como independentes, ou que defendiam que o desenvolvimento é um pré-requisito para a aprendizagem, ou que tomavam ambos os processos como sinônimos, como se coincidissem sempre.

Para o autor, a aprendizagem e o desenvolvimento estão relacionados desde o início da vida da criança. A primeira não depende apenas de que o segundo atinja certo nível, mas também pode estimulá-lo. Assim, o aprendizado não começa na escola, mas qualquer aprendizado escolar tem sempre uma história prévia. Além do ensino sistemático, outras interações sociais são capazes de estimular o desenvolvimento da criança, tais como aquelas estabelecidas em momentos de brincadeiras e em atividades cotidianas (BRAGA, 1995; VYGOTSKY, 1998).

Segundo Vygotsky (1998, 1934/2001) para descobrir as relações entre o processo de desenvolvimento e de aprendizado, faz-se necessário determinar ao menos dois níveis de desenvolvimento: nível de desenvolvimento real, das funções que já amadureceram, ou seja, funções resultantes de ciclos de desenvolvimento já completados, determinado pelo que a criança 
consegue realizar sem ajuda; nível de desenvolvimento potencial, das funções em vias de maturação, determinado pelo que a criança consegue realizar com ajuda de alguém mais experiente. A distancia entre o nível de desenvolvimento real e o nível de desenvolvimento potencial é a zona de desenvolvimento proximal (ou imediato). Enquanto o nível de desenvolvimento real caracteriza o desenvolvimento retrospectivamente, o nível de desenvolvimento potencial o caracteriza prospectivamente, permitindo-nos delinear o futuro imediato da criança. Por isso, a zona de desenvolvimento proximal é uma zona de aprendizagens, que determina o campo das transições possíveis para a criança, define as funções que estão em processo de maturação.

Assim, a relação entre estes dois processos é complexa e dinâmica; aprendizado e desenvolvimento não coincidem como se um fosse a sombra do outro, tampouco o desenvolvimento deve se completar para que a aprendizagem seja possível. Ao contrário, a aprendizagem começa daquilo que ainda não é maduro na criança.

Por outro lado, mesmo em colaboração a criança não consegue resolver qualquer problema ou imitar qualquer comportamento, mas apenas o que está dentro da sua zona de desenvolvimento proximal. Mas, o ponto fundamental desta tese é que a aprendizagem e a imitação podem fazer com que a criança avance em seu desenvolvimento, pois o que está na zona de desenvolvimento proximal hoje, estará no nível de desenvolvimento atual amanhã. Para resultar em desenvolvimento, o aprendizado deve ser adequadamente organizado, definindo-se o que está na zona de desenvolvimento proximal, aquilo que a criança é capaz de aprender no momento, o que desperta vários processos internos que estão em fase de maturação, que só são capazes de operar quando a criança age em cooperação ou com ajuda. Estes processos poderão ser realizados com independência quando forem internalizados, apreendidos. Nessa perspectiva, a 
inteligência é concebida como a habilidade para aprender e não como aprendizagens prévias, já efetuadas (VYGOTSKY, 1998, 1934/2001).

O desenvolvimento e a aprendizagem vão de níveis menos complexos para níveis mais complexos, pressupondo a interação entre sujeitos inseridos em determinados contextos sóciohistóricos, pois as trocas sociais são as alavancas para alcançar outros níveis de aprendizagem. Deste modo, as diferenças quanto à capacidade para aprender devem-se, principalmente, às diferenças no ambiente social em que as crianças vivem, de modo que crianças que se encontram em um mesmo nível de desenvolvimento atual podem apresentar níveis de desenvolvimento proximais distintos (PALANGANA, 2001; QUEIROZ E MELO, 2004; VYGOTSKY, 1934/2001).

Por meio desta noção, Vygotsky sugere que todas as funções do desenvolvimento cultural da criança aparecem primeiro no plano social, desenvolvendo-se entre as pessoas como uma categoria interpsicológica e, depois, aparecem no plano individual, como uma categoria intrapsicológica, pois todas as funções mentais superiores resultam de uma reconstrução interna de uma atividade social partilhada (AMORIM, 1997; BRAGA, 1995; VYGOTSKY, 1934/2001). “Ao descrever esta passagem do social para o individual, ele destaca a importância da experiência partilhada, da comunhão de situações, do diálogo, da colaboração, concebendo, desse modo, o aprendizado como um processo de trocas e, portanto, verdadeiramente social” (PALANGANA, 2001, p. 152).

Quando outras pessoas chamam a atenção da criança para alguns objetos e os nomeiam, estabelecem relações entre estes, auxiliando-a a conceber a realidade de modo mais complexo. Neste processo, o outro também ajuda a criança a focar sua atenção sobre o que é essencial, ignorando os elementos irrelevantes. Posteriormente, ao tentar compreender a realidade, a criança poderá fazer isso por si só (PALANGANA, 2001; VYGOTSKY, 1998). 
Deste modo, o papel do social é tão importante quanto o do sujeito na constituição das funções superiores do pensamento. Por outro lado, a relação do indivíduo com o mundo e com as pessoas não é uma relação direta, mas é uma relação mediada pelos sistemas simbólicos (AMORIM, 1997).

Neste mesmo sentido, Palangana (2001, p. 131) afirma:

A internalização do conhecimento acumulado pelos homens ao longo de sua história e disponível no meio social em que a criança vive se dá, especialmente, pela linguagem (...). Interagindo com as pessoas que integram seu meio ambiente, a criança apreende seus significados lingüísticos e, com eles, o conhecimento de sua cultura.

Assim, ao falar do valor da interação social e da comunicação entre os homens para a constituição das funções psicológicas superiores, Vygotsky compara a importância que Marx e Engels dão ao instrumento para o trabalho e para a interação homem-ambiente, com a importância que os signos têm para a atividade psicológica, pois ambos desempenham uma função mediadora. Assim como os instrumentos medeiam a relação do homem com a natureza e, ao modificá-la, o homem modifica-se a si mesmo, os signos medeiam as relações entre a realidade externa e o pensamento, o que dá às funções psíquicas humanas um caráter mediatizado (AMORIM, 1997; GÓES, 2002; PALANGANA, 2001; VYGOTSKY, 1998).

Os instrumentos são voltados externamente para provocar mudanças nos objetos, para dominar a natureza, e os signos são voltados internamente, para que o indivíduo controle seu próprio comportamento. Contudo, ambos estão vinculados; é da relação entre a fala (uso de signos) e a inteligência prática (uso de instrumentos), que emergem as funções psicológicas superiores (VYGOTSKY, 1998).

Contudo, estas funções não emergem simplesmente da somatória de ambos os fatores, mas se transformam após um longo processo de desenvolvimento. Neste sentido, Vygotsky (1934/2001) afirma que o pensamento e a linguagem têm raízes genéticas diferentes: podemos 
constatar um estágio pré-intelectual no desenvolvimento da fala (como o grito, o balbucio e as primeiras palavras) e um estágio pré-verbal no desenvolvimento do pensamento (que se caracteriza por manifestações intelectuais rudimentares, associadas à manipulação de instrumentos). Até determinado ponto, o desenvolvimento do pensamento e da linguagem seguem linhas diferentes, então ambas se cruzam, quando “[...] o pensamento se torna verbal e a fala se torna intelectual” (p. 133). O desenvolvimento de ambos os processos depende dos instrumentos de pensamento e da experiência sociocultural do indivíduo. Assim, “[...] o pensamento verbal não é uma forma natural e inata de comportamento, mas uma forma históricosocial [...]” (p. 149).

Tal como as demais funções psicológicas complexas, o pensamento verbal também se desenvolve da socialização para a individualização. Por trás do pensamento verbal encontra-se a linguagem interior; a linguagem, por sua vez, é inicialmente social (categoria interpsicológica) e se torna interiorizada (categoria intrapsicológica), sendo a fala egocêntrica ${ }^{23}$ um período de transição (VYGOTSKY, 1934/2001).

No início, a fala do outro dirige a atenção e a ação da criança. Gradualmente, a criança passa a usar a fala para afetar seu ambiente (Braga, 1995). Contudo, neste momento, a criança não diferencia a fala para os outros (fala social) da fala para si, de modo que a linguagem egocêntrica surge como uma diferenciação da primeira. A fala egocêntrica acompanha a ação, refletindo o processo de solução das tarefas; aos poucos, ela vai se dirigindo cada vez mais para o início da ação, servindo “[...]

\footnotetext{
${ }^{23}$ A idéia de fala egocêntrica tem, para Vygotsky (1934/2001), uma conotação diferente daquela adotada por Piaget. Para este autor, a criança é inicialmente individual e se desenvolve para o social, de modo que a fala egocêntrica representaria o egocentrismo da criança e desapareceria conforme a criança se socializa. Vygotsky, ao contrário, acredita que as funções da criança são inicialmente sociais, desenvolvendo-se no sentido de sua interiorização, individualização. Desta forma, a fala egocêntrica representaria um período de transição entre a fala social e a fala interior; ao invés de desaparecer, a fala egocêntrica se tornaria cada vez mais abreviada e ininteligível para os outros, adquirindo cada vez mais as características da fala interior.
} 
aos objetivos da orientação intelectual, da tomada de consciência da superação das dificuldades e dos obstáculos, da reflexão e do pensamento” (VYGOTSKY, 1934/2001, p. 430).

Por isso, a fala egocêntrica tem uma função importante na realização de tarefas; ela não acompanha simplesmente a ação, mas tem um papel específico em seu planejamento e em sua realização, servindo ao pensamento da criança. Por sua função, ela é uma linguagem interior, pois é uma linguagem para si, mas, devido a sua sonorização, ainda é estruturalmente exterior. Em seguida, a fala egocêntrica vai se tornando cada vez mais fragmentada e ininteligível para os outros, até desaparecer a sua sonorização, tornando-se uma fala interna. Ela se interioriza porque muda a sua função, pois há uma diferenciação crescente do que é fala para os outros (linguagem social) e do que é fala para si (linguagem interior). A ausência de sonorização também reflete a capacidade crescente para a abstração, pois a criança consegue, então, lidar com a imagem da palavra, não sendo necessário pronunciá-la. Aqui a linguagem adquire função de auto-regulação, controlando as atividades mentais e o comportamento do indivíduo. Ela determina e domina a ação, tendo função planejadora, além de continuar a refletir o mundo exterior (PALANGANA, 2001; VYGOTSKY, 1934/2001).

Quando a linguagem para si diferencia-se da linguagem para os outros, sendo internalizada, as estruturas da linguagem previamente dominadas pela criança tornam-se estruturas básicas de seu pensamento (VYGOTSKY, 1934/2001).

Neste sentido, Palangana (2001, p. 99) afirma que

A aquisição de um sistema lingüístico organiza, pois, todos os processos mentais da criança, dando forma ao pensamento. Mas, [...] além de indicar um objeto do mundo externo, a palavra também especifica as principais características deste objeto, generalizando-as para, em seguida, relacioná-las em categorias. Daí a importância da linguagem para o desenvolvimento do pensamento: ela sistematiza a experiência direta da criança e serve para orientar seu comportamento [...]. 
Deste modo, observamos a importância que Vygotsky (1934/2001) atribui à linguagem para o desenvolvimento do pensamento. Contudo, segundo o autor, mesmo no adulto não há uma fusão constante entre o pensamento e a linguagem. Estes dois fenômenos podem ser entendidos como dois círculos que se cruzam: na parte em que os dois coincidem, há o pensamento verbal; contudo este não engloba todos os tipos de pensamento nem de linguagem. Por exemplo, o pensamento instrumental e técnico, vinculado ao intelecto prático, pode não manter relação direta com o pensamento verbal, assim como repetir na linguagem interior um poema que foi decorado pode não ter nenhuma relação com o pensamento. Deste modo, a fusão entre a linguagem e o pensamento só vigora no campo do pensamento verbalizado.

Entretanto, o pensamento verbal não pode ser estudado pela divisão entre linguagem e pensamento, pois, isoladamente, estes não contêm as propriedades inerentes à totalidade. Por isso, o autor substitui o método da decomposição pelo método da análise, que desmembra a totalidade do pensamento verbalizado em várias unidades, sendo que estas unidades não perdem as propriedades inerentes à totalidade. A unidade ${ }^{24}$ do pensamento verbalizado pode ser encontrada no aspecto interno da palavra, ou seja, em seu significado. O significado pertence tanto ao reino da linguagem quanto ao reino do pensamento. Pertence ao reino da linguagem porque é uma parte inalienável da palavra, pois, sem significado, a palavra é som vazio. Por outro lado, o significado da palavra é também um fenômeno do pensamento, pois “[...] do ponto de vista psicológico o significado da palavra não é senão uma generalização ou conceito” (VYGOTSKY, 1934/2001, p. 398).

\footnotetext{
${ }^{24} \mathrm{O}$ autor menciona que há dois métodos distintos de análise psicológica. O primeiro é a decomposição das totalidades psicológicas em elementos (por exemplo, decompor o pensamento verbal em pensamento e linguagem); contudo, o autor salienta que não é possível explicar as propriedades do todo partindo das propriedades de seus elementos. O segundo método de análise é a decomposição da totalidade em unidades, sendo a “(...) unidade um produto da análise que, diferente dos elementos, possui todas as propriedades que são inerentes ao todo e, concomitantemente, são partes vivas e indecomponíveis dessa unidade” (VYGOTSKY, 1934/2001, p. 8). Neste sentido, o significado da palavra é a unidade que possui todas as propriedades do pensamento verbalizado.
} 
Segundo Vygotsky (1934/2001, p.12),

Para se comunicar alguma vivência, não há outro caminho a não ser a inserção desse conteúdo numa determinada classe, em um grupo de fenômenos, e isto, [...] requer necessariamente generalização. Verifica-se [...] que a comunicação pressupõe necessariamente generalização e desenvolvimento do significado da palavra [...]. Assim, as formas superiores de comunicação psicológicas, [...] só são possíveis porque, no pensamento, o homem reflete a realidade de modo generalizado.

Desta forma, é possível perceber a importância atribuída por Vygotsky aos conceitos (significados das palavras), pois, sem eles, não são possíveis as formas superiores de comunicação e de pensamento. É por meio deles que o homem compreende a realidade que o cerca. Visto que o significado da palavra é a unidade viva do pensamento verbalizado, pertencendo tanto à linguagem quanto ao pensamento, e visto a importância que o autor atribui ao meio social para o desenvolvimento destas funções superiores, é possível concluir que o meio social é fundamental para o desenvolvimento dos conceitos.

Embora valorize a influência do meio social para o desenvolvimento psicológico, o autor afirma que a formação de conceitos não é um processo reprodutivo, baseado na associação entre símbolos verbais e objetos, mas é um processo produtivo, que é resultado de um longo processo de desenvolvimento. No que se segue, serão expostos alguns pontos da teoria de Vygotsky acerca de como os diferentes tipos de conceitos se desenvolvem.

\subsection{O processo de formação de conceitos}

Para Vygotsky (1934/2001), a descoberta de que os conceitos se desenvolvem foi primordial em seus estudos sobre o tema, superando a crença na constância e na imutabilidade do significado da palavra. Este processo de desenvolvimento se inicia, segundo o autor, nas fases mais precoces da infância, mas as funções psicológicas que resultam na formação de conceitos 
amadurecem apenas na puberdade. Antes desta etapa, encontramos formações intelectuais que se assemelham aos conceitos e que podem ser confundidos com eles, pois executam funções semelhantes. Contudo, podemos encontrar diferenças qualitativas em sua natureza, sua estrutura e seu modo de atividade.

Neste sentido, o desenvolvimento dos processos que levarão à formação dos conceitos apresenta três estágios, os quais foram verificados em condições artificiais de análise experimental e que, por isso, são apresentados em uma seqüência lógica que se desvia do processo real de desenvolvimento dos conceitos. Por não ser o objetivo deste trabalho a identificação precisa dos estágios deste processo, estes serão sucintamente apresentados.

No primeiro estágio descrito por Vygotsky (1934/2001), há o agrupamento de objetos diferentes, que são relacionados entre si pela percepção da criança, formando uma imagem mista e instável. Isso ocorre porque a criança tenta substituir a carência de nexos objetivos por nexos subjetivos. Como estes significados são frutos das impressões da criança, estes podem coincidir ou não com os significados atribuídos pelos adultos aos mesmos objetos.

No segundo estágio, ocorre a formação de complexos. Estes são estruturados por grupos de objetos particulares, unificados com base em vínculos reais (objetivos) existentes entre tais objetos, o que diferencia esta fase da anterior, pois, na formação do amontoado de objetos, a criança se baseia em vínculos subjetivos. Contudo, o fato de se basear em vínculos reais e concretos, que se revelam na experiência imediata da criança, diferencia os complexos dos conceitos, pois estes são formados com base em vínculos abstratos e lógicos (o indivíduo abstrai de uma série de características presentes nos objetos, aquelas que são fundamentais para definilos). Além disso, nos conceitos, todos os objetos estão ligados entre si por vínculos do mesmo tipo, logicamente idênticos, essenciais e uniformes. Já nos complexos, cada objeto pode estar ligado a todo o grupo ou a objetos particulares com base em vínculos diversos, frequentemente 
sem nada em comum entre si. Nos complexos, de modo diferente do que ocorre nos conceitos, não existe um vínculo hierárquico entre os objetos, e a criança não abstrai um atributo dos demais para que este sirva de base para a inclusão de novos elementos ao conjunto, mas, nesta fase, os objetos particulares estabelecem vínculos entre si.

Nos complexos, a criança pode agrupar objetos com base em alguma característica que lhe chame a atenção; ou estes agrupamentos podem estar baseados nas relações de objetos estabelecidas na experiência prática, segundo o traço da cooperação funcional (por exemplo, colher, copo e prato); ou cada elo da cadeia pode estar ligado ao anterior e ao próximo em algum sentido (neste caso, o segundo objeto pode estar ligado ao terceiro com base em outra característica, de modo que o primeiro objeto não tenha nenhuma relação com o terceiro); a criança também pode associar dois objetos considerados parecidos e, ao segundo objeto, acrescenta outro e assim por diante (por exemplo, a criança associa o triângulo ao trapézio, depois associa o trapézio ao quadrado).

No final deste estágio, há a formação do pseudoconceito, que é a forma predominante na idade pré-escolar. Este pode ser confundido com o conceito por serem exteriormente parecidos, contudo, o processo de formação e o interior do pseudoconceito revelam que este é um complexo. Neste, por exemplo, o indivíduo não abstrai as características essenciais para agrupar todos os triângulos de uma amostra, mas o faz por associação simples. Ou seja, a criança não agrupa todos os triângulos por serem estes figuras planas, com três ângulos e três lados (sendo estas as características essenciais dos triângulos), mas agrupa os triângulos por perceber que são semelhantes entre si. Além disso, diferentemente do que ocorre no pensamento por conceitos, no pensamento por complexos cada objeto conserva sua autonomia concreta, não se fundindo com outros elementos do grupo. 
Este estágio permite que o pensamento da criança dê os primeiros passos na combinação e na generalização das impressões dispersas e dos elementos concretos percebidos por ela. Contudo, a formação de conceitos não depende apenas destes processos de combinação e generalização, mas também da discriminação, da abstração e do isolamento de determinados elementos, além da “[...] habilidade de examinar esses elementos discriminados e abstraídos fora do vínculo concreto e fatual em que são dados na experiência” (VYGOTSKY, 1934/2001, p. 220). Nisso, o pensamento por complexos é impotente, pois é repleto de excedentes e de abstração fraca, sendo também fraco o processo de discriminação de atributos.

É apenas no terceiro estágio que ocorre o desenvolvimento da decomposição, da análise e da abstração. A criança aprende a atentar para alguns traços semelhantes entre os objetos, utilizando-os de maneira estável para agrupá-los. Assim, no início deste estágio, a criança começa a formar conceitos potenciais, agrupando objetos segundo atributos comuns. Todavia, o conceito potencial não é ainda um verdadeiro conceito, mas algo que poderá vir a sê-lo.

Segundo Vygotsky (1934/2001, p. 226), o pensamento potencial é muito importante para a evolução dos conceitos infantis, pois, “[...] pela primeira vez, abstraindo determinados atributos, a criança destrói a situação concreta, o vínculo concreto dos atributos [...]”. O conceito propriamente dito, “[...] surge quando uma série de atributos abstraídos torna a sintetizar-se, e quando a síntese abstrata assim obtida se torna forma basilar de pensamento com o qual a criança percebe e toma conhecimento da realidade que a cerca”. Neste processo de formação do verdadeiro conceito ${ }^{25}$ cabe um papel central à palavra, pois é por meio dela que a criança orienta

\footnotetext{
${ }^{25}$ Como apresentado no capítulo anterior, os autores que discutem as diferentes visões a respeito dos conceitos incluem a teoria de Vygotsky na visão clássica. Ao chamar de conceitos verdadeiros aqueles formados com base na abstração de atributos essenciais, o autor realmente parece se aproximar desta visão, segundo a qual os conceitos são formados com base na abstração de atributos necessários e suficientes para defini-los.
} 
sua atenção para determinados atributos, sintetiza-os, simboliza o conceito abstrato e com ele opera.

Segundo o autor, é apenas na adolescência que o indivíduo chega ao pensamento por conceitos, mas este é um período de transição, não de conclusão deste processo. Neste período, formas primitivas de pensamento (amontoados de objetos e complexos) são gradualmente relegadas a segundo plano, tornando-se cada vez mais freqüente o uso dos conceitos verdadeiros, que apareciam antes esporadicamente. Assim, diferentes formas de pensamento coexistem, sendo que nem mesmo o adulto pensa sempre por conceitos. Embora o pensamento adulto tenha acesso à formação de conceitos e opere com eles, tal não ocorre sempre. Ou seja, o pseudoconceito e o conceito potencial não operam exclusivamente no pensamento da criança, mas são formas transitórias nas quais também se encontra o pensamento habitual do adulto, baseado em sua experiência cotidiana (KEIL, 1989; VYGOTSKY, 1934/2001).

No adolescente, assim como no adulto, há uma discrepância entre a formação do conceito e a sua definição verbal, pois a existência do conceito e a consciência dele não surgem ao mesmo tempo, sendo que "o primeiro pode surgir antes e atuar independentemente do segundo" (VYGOTSKY, 1934/2001, p. 229). O indivíduo, embora possa usar um conceito em uma situação concreta, tem dificuldades em defini-lo verbalmente.

Verifica-se nesse fato a confirmação direta de que os conceitos não surgem simplesmente como resultado de uma elaboração lógica desses ou daqueles elementos da experiência, que a criança não atina sobre seus conceitos, e que estes lhe surgem de modo bem diferente e só mais tarde ela toma consciência deles e lhes dá configuração lógica (VYGOTSKY, 1934/2001, p. 230).

O autor critica a teoria sobre formação de conceitos da psicologia tradicional, vigente em sua época, segundo a qual o conceito se funda em uma série de noções concretas, supondo que, na formação de conceitos, ocorra uma intensificação dos traços comuns a certo número de objetos, enquanto os traços pessoais são ignorados. A soma dos traços comuns formaria o 
conceito. O autor afirma que o processo de formação de conceitos não segue esse caminho lógico. O desenvolvimento dos conceitos também não segue a ascensão na pirâmide de conceitos (como se a criança aprendesse primeiro os conceitos mais particulares, evoluindo para os mais gerais).

Segundo o autor, o conceito não é fruto apenas de processos de associações, mas surge através de uma operação intelectual da qual participam, numa combinação específica, todas as funções mentais elementares. Nesta operação, as palavras são utilizadas como meios para orientar ativamente a atenção, para abstrair certos traços e para representá-los por meio de símbolos (VYGOTSKY, 1934/2001).

Estes estágios do desenvolvimento dos conceitos foram estabelecidos por meio de estudos, nos quais foram utilizados conceitos artificiais. Embora sejam descritos de forma seqüencial, o próprio autor atenta para o fato de que eles não aparecem nesta seqüência lógica no processo real de desenvolvimento de conceitos. Não obstante, os estágios descritos por Vygotsky parecem estar relacionados aos conceitos formados em situações espontâneas, pois pressupõem o contato direto do indivíduo com os objetos (KEIL, 1989). Além destes conceitos formados na vida cotidiana, Vygotsky (1934/2001) também menciona a existência de conceitos que seguem um caminho diferente em seu desenvolvimento, pois surgem a partir de condições formais de ensino.

Ao fazer esta distinção entre dois tipos de conceitos, Vygotsky introduziu na psicologia uma divisão dos conceitos que leva em conta não o seu conteúdo, mas o caráter específico de seu processo de formação (NUÑEZ; PACHECO, 1998). Assim, Vygotsky (1934/2001) chamou a atenção para a existência de dois esquemas conceituais: os conceitos espontâneos e os conceitos científicos. Os conceitos espontâneos são formados no cotidiano da criança, existindo em seu repertório de aprendizagem antes de seu ingresso na escola. Os conceitos científicos, por outro lado, são aqueles formados no processo escolar orientado e organizado, juntando-se e interagindo 
com os conceitos espontâneos, modificando-os como resultado da aprendizagem. Para este autor, é no campo dos conceitos científicos que “[...] o pensamento ultrapassa o limite que separa o préconceito dos verdadeiros conceitos $^{26 ”}$ (VYGOTSKY, 1934/2001, p. 296).

Segundo Vygotsky (1934/2001), Piaget também fez uma distinção entre conceitos espontâneos e não-espontâneos. Os primeiros seriam noções infantis da realidade, em cujo desenvolvimento o pensamento infantil propriamente dito tem um papel decisivo, enquanto os segundos seriam noções que surgem sob a influência dos conhecimentos que a criança assimila das pessoas que a rodeiam. Contudo, para Vygotsky, Piaget errou ao afirmar que os conceitos não-espontâneos (dentre os quais poderíamos inserir os conceitos científicos), por sofrerem influências das pessoas que cercam a criança, não refletem as peculiaridades do seu pensamento.

Vygotsky, apesar de atribuir ao meio social uma importância fundamental para o processo de formação de conceitos, afirma que estes não são decorados (nem mesmo os conceitos científicos), mas desenvolvidos por meio da atividade de pensamento da criança. Visto que, para este autor, a criança reelabora os conceitos aprendidos com os adultos, há uma originalidade nos conceitos infantis, tanto nos espontâneos quanto nos científicos, sendo de se esperar que um estudo destes revele todas as peculiaridades qualitativas básicas do pensamento infantil em uma determinada fase.

Acreditar que os conceitos científicos não refletem as características do pensamento da criança seria acreditar que estes podem ser absorvidos de forma pronta. Para Vygotsky, ao tentarmos ensinar conceitos já prontos, a criança não assimila o conceito, mas a palavra, e vê-se impotente para empregar conscientemente o conhecimento assimilado. Portanto, no momento em

\footnotetext{
${ }^{26}$ Ao chamar os conceitos científicos de conceitos verdadeiros, o autor se aproxima da concepção clássica, que considera como conceitos apenas aqueles claramente definidos.
} 
que a criança conhece pela primeira vez o significado de uma palavra, o desenvolvimento do conceito não terminou, mas está apenas começando.

Embora conceitos prontos não possam ser ensinados, não podemos excluir a possibilidade de intervenção neste processo, de modo que métodos de ensino mais sutis e indiretos podem ter uma interferência positiva, levando a um avanço no processo de formação de conceitos infantis. Além disso, a aprendizagem de novos conceitos pode levar a um desenvolvimento superior mesmo dos conceitos já constituídos na criança. A aprendizagem é, na idade escolar, o momento determinante de todo o destino do desenvolvimento intelectual da criança, inclusive do desenvolvimento dos conceitos.

A afirmação de Piaget de que os conceitos espontâneos são baseados no pensamento infantil, enquanto os científicos não sofrem a influência deste pensamento, sendo absorvidos das idéias dos adultos, também leva a pensar que haja uma barreira intransponível entre os dois tipos de conceitos. Para Piaget, a única relação existente entre os dois é a relação de oposição e de deslocamento de uns pelos outros, de forma que os conceitos espontâneos seriam substituídos gradualmente pelos conceitos científicos.

Para Vygotsky (1934/2001, p. 262), ao contrário, não há antagonismos no processo de formação de conceitos espontâneos e científicos, mas relações complexas e positivas. Os conceitos espontâneos não são mecanicamente substituídos pelos conceitos científicos, como algo vindo de fora para dentro, mas “[...] os conceitos científicos de tipo superior não podem surgir na cabeça da criança senão a partir de tipos de generalização elementares e inferiores preexistentes [...]”, ou seja, a partir dos conceitos espontâneos.

O limite entre eles é fluido, de modo que um exerce influência sobre o outro. Por um lado, o desenvolvimento dos conceitos científicos se apóia em um determinado nível de maturação dos conceitos espontâneos, só sendo possível quando estes atingiram um nível próprio. Assim, para o 
ensino de determinados conceitos científicos, parte-se do pressuposto de que a criança possua um sistema de conceitos já elaborado por meio da experiência espontânea, de modo que os conceitos científicos são aprendidos por mediação dos conceitos espontâneos. Por outro lado, a aprendizagem de conceitos científicos influencia o desenvolvimento dos conceitos espontâneos, fazendo com que evoluam para um nível superior, pois há uma reformulação destes e a criança passa a operar com estes de maneira mais consciente e intencional.

Este tipo de relação de reciprocidade só é possível porque os conceitos espontâneos e os científicos se desenvolvem de maneiras distintas. Os conceitos espontâneos surgem da experiência pessoal da criança, são formados no cotidiano, principalmente por tentativa e erro, sendo fortemente saturados de experiência empírica. Eles têm por base os atributos comuns dos objetos, muitos dos quais não são essenciais, e se caracterizam pela ausência de percepção consciente de suas relações. Os conceitos científicos, por sua vez, surgem da experiência escolar, ou seja, de um processo de ensino organizado e orientado, que começa com a conscientização das características essenciais dos objetos, sendo estas características enumeradas nas definições dos conceitos $^{27}$ (NUÑEZ; PACHECO, 1998; VYGOTSKY, 1934/2001).

Desta forma, nos primeiros momentos do seu desenvolvimento, estes conceitos se desenvolvem em sentido inverso, por vias opostas. A primeira fase no desenvolvimento dos conceitos espontâneos está vinculada à experiência com objetos reais, embora a criança também encontre explicações por parte dos adultos, em suas experiências diárias. Ela conhece o objeto e tem um conceito dele, mas “[...] não tem consciência do próprio conceito, do ato propriamente dito de pensamento através do qual concebe esse objeto” (VYGOTSKY, 1934/2001, p. 345).

\footnotetext{
${ }^{27}$ Esta noção de que os conceitos espontâneos são formados com base nos atributos comuns, enquanto os conceitos científicos são formados com base nos atributos essenciais, aproxima-se bastante dos postulados da visão teórica, que afirma que as crianças pequenas atentam às características mais freqüentes e superficiais, mas, à medida que se desenvolvem, passam a focar a atenção nos atributos definidores dos conceitos.
} 
Apenas relativamente tarde esta criança tomará consciência deste conceito, da formulação e definição verbal deste, bem como de sua aplicação em relações lógicas entre os conceitos. Assim, no que diz respeito aos conceitos espontâneos, a criança caminha do objeto para o conceito, caminha de baixo para cima. Já o desenvolvimento do conceito científico não começa pela relação imediata com os objetos. Este desenvolvimento começa habitualmente pelo trabalho com o próprio conceito, com sua definição verbal, pela sua aplicação em operações lógicas. Portanto, no desenvolvimento dos conceitos científicos, a criança caminha do conceito para o objeto, de cima para baixo.

Devido a estas peculiaridades, em uma mesma criança de uma mesma idade, estes conceitos se revelam em diferentes níveis de desenvolvimento, apresentando pontos fortes e fracos, de modo que se comportam de maneiras diferentes em tarefas idênticas. Os conceitos espontâneos, por surgirem da experiência pessoal da criança, apresentam como ponto forte a facilidade de serem aplicados em situações espontâneas e concretas. Contudo, por nunca terem sofrido uma formulação científica, apresentam como fraqueza a dificuldade de abstração e de operação arbitrária (intencional e consciente), além de serem definidos com dificuldade. Ou seja, a criança não consegue operar com eles em um nível não-concreto. Por outro lado, por surgirem da experiência escolar, os conceitos científicos podem ser formulados e definidos com maior facilidade, sendo mais facilmente utilizados de maneira intencional e consciente, na realização de operações lógicas e na correlação com outros conceitos. Entretanto, são pobres em experiência pessoal, de modo que a fraqueza dos conceitos científicos pode ser encontrada em seu verbalismo e em sua falta de concretude, sendo dificilmente transferidos para situações concretas e espontâneas do cotidiano (VYGOTSKY, 1934/2001).

Estas características dos dois tipos de conceitos explicam porque as crianças de idade escolar apresentam um desempenho melhor em testes que envolvem conceitos científicos do que 
em testes que envolvem conceitos espontâneos. Os maus resultados referentes aos conceitos espontâneos são atribuídos ao fato de que, no teste, a criança é exigida a fazer de forma consciente e arbitrária o que ela faz todos os dias de forma espontânea e não arbitrária. Quanto às questões que envolvem conceitos científicos já conhecidos pela criança, a elaboração por parte dela não é feita no momento em que o teste é aplicado. Há um processo por trás disso. A elaboração e a formação destes conceitos foram feitas com a colaboração de um adulto, no processo de aprendizagem. No momento do teste, a criança usa da imitação, utilizando-se sozinha dos resultados da colaboração anterior feita por seu professor. Mesmo que o professor não esteja ao seu lado no momento de resolver um problema semelhante ao estudado na escola, ela continua agindo em colaboração. Nos testes com conceitos espontâneos, a criança é exigida a fazer voluntariamente o que consegue fazer espontaneamente, nos testes com conceitos científicos, a criança é exigida a fazer em colaboração com o professor o que ela não conseguiria fazer espontaneamente $^{28}$ (VYGOTSKY, 1934/2001).

Além disso, as crianças conseguem usar os conceitos científicos de maneira intencional e consciente nos testes porque a característica essencial deste tipo de conceito é a possibilidade de serem sistematizados, conscientizados e utilizados de forma arbitrária, enquanto que a característica essencial dos conceitos infantis é o fato de serem não-sistematizados, nãoconscientizáveis e espontâneos. Para o autor, a não-conscientização da criança a respeito de seus conceitos espontâneos se deve a falta de sistematização dos mesmos.

\footnotetext{
${ }^{28}$ Esta explanação nos ajuda a compreender uma questão que permanece implícita na teoria de Vygotsky acerca do processo de formação de conceitos, qual seja: se o autor acredita que os conceitos verdadeiros (formados por base na abstração das características que lhe são essenciais) só começam a ser formados na adolescência, como pode a criança em idade escolar aprender conceitos científicos (também denominados conceitos verdadeiros)? Ao que parece, a criança consegue abstrair as características essenciais a uma classe de fenômenos porque o faz em cooperação com o professor. A capacidade para formar este tipo de conceitos ainda está na zona de desenvolvimento proximal da criança em idade escolar; por meio da colaboração, a criança começa a desenvolver tal capacidade.
} 
O fato de que os conceitos científicos estão organizados em um sistema hierárquico de inter-relações é a diferença fundamental entre estes e os conceitos espontâneos. Neste sistema, os conceitos científicos estão relacionados segundo a sua abrangência, de modo que os conceitos menos abrangentes estão subordinados aos mais abrangentes; é apenas dentro do seu sistema que um conceito científico pode ser compreendido, conscientizado e usado de forma arbitrária ${ }^{29}$ (NUÑEZ; PACHECO, 1998; TOLENTINO et al., 1986; VYGOTSKY, 1934/2001).

Contudo, a sistematização e a tomada de consciência a ela vinculada não surgem de fora para dentro, mas a aprendizagem de conceitos científicos pressupõe a existência de conceitos infantis (espontâneos) bastante ricos e maduros, uma vez que a relação do conceito científico com o objeto é mediada por conceitos espontâneos (a criança não precisa entrar em contato com cada objeto envolvido no conceito científico, visto que ela já conheceu estes objetos por meio de suas experiências espontâneas). Por outro lado, a estrutura dos sistemas que surge no campo dos conceitos científicos é também transferida para o campo dos conceitos espontâneos, que têm sua estrutura interna reconstruída e modificada. Assim, ao sistematizar seus conceitos espontâneos, o indivíduo também os torna conscientes e arbitrários, ou seja, estes podem ser utilizados de maneira intencional e consciente. Deste modo, segundo Vygotsky (1934/2001, p. 295), “os conceitos científicos são os portões através dos quais a tomada de consciência penetra no reino dos conceitos infantis”.

O autor explica melhor esta modificação da estrutura dos conceitos espontâneos dando o seguinte exemplo: a criança frequentemente aprende a palavra flor antes de aprender a palavra rosa. Quando a criança já aprendeu ambas as palavras, a primeira, apesar de ser mais ampla que a segunda, não é percebida como mais genérica, ou seja, a criança não percebe que o conceito de flor é mais geral que o conceito de rosa, pois estes conceitos não estão inseridos em um sistema.

\footnotetext{
${ }^{29}$ Considerar os conceitos dentro deste tipo de sistema hierárquico é uma característica da visão clássica.
} 
Estes permanecem por muito tempo lado a lado. Quando a criança passa a desenvolver uma nova estrutura para os seus conceitos, o que ocorre inicialmente por meio dos conceitos científicos, o conceito de flor, apreendido de forma espontânea, é também generalizado e sua relação com o conceito de rosa muda, pois percebe a relação entre os dois conceitos, surgindo um sistema de conceitos. Ela percebe, por exemplo, que há um conceito mais genérico (planta), há um conceito subordinado a este (flor), outro subordinado a este (rosa) e assim por diante.

Visto que o conceito espontâneo também poderá chegar a ser conscientizado e sistematizado, tal como o científico, eles não podem ser separados no pensamento, pois eles estão no mesmo nível, embora tenham atingido este nível por caminhos diferentes, inversos. Ambos os processos estão inter-relacionados, de modo que um tipo de conceito abre o caminho para que o outro continue a desenvolver-se: o conceito espontâneo abre caminho para que o conceito científico continue crescendo de cima para baixo; o conceito científico, por sua vez, abre caminho para que o conceito espontâneo continue crescendo de baixo para cima.

Esta tese de que a aprendizagem dos conceitos científicos se apóia no desenvolvimento dos conceitos espontâneos, ao mesmo tempo em que o surgimento daqueles estimula um maior nível de desenvolvimento destes, relembra o posicionamento do autor quanto à questão da relação entre a aprendizagem e o desenvolvimento. Para o autor, embora certo nível de desenvolvimento seja premissa para que uma dada aprendizagem possa ocorrer, não se faz necessário que os ciclos de desenvolvimento estejam totalmente completados antes do início da aprendizagem. Há, para ele, uma influencia mútua entre o desenvolvimento e a aprendizagem. A aprendizagem não anda atrás do desenvolvimento, nem paralela a ele, mas deve estar um degrau acima do desenvolvimento, puxando este para um nível superior. 
No processo educacional há uma colaboração entre a criança e o adulto, por meio da qual ocorre o amadurecimento das funções psicológicas superiores da criança. A essa colaboração, deve-se o amadurecimento precoce dos conceitos científicos.

Segundo Vygotsky (1934/2001, p. 351),

[...] a tomada de consciência e a arbitrariedade dos conceitos, propriedades não inteiramente desenvolvidas dos conceitos espontâneos do aluno escolar, situamse inteiramente na zona de seu desenvolvimento imediato, ou seja, revelam-se e tornam-se eficazes na colaboração com o pensamento do adulto. Isto nos explica tanto o fato de que o desenvolvimento dos conceitos científicos pressupõe um certo nível de elevação dos espontâneos, no qual a tomada de consciência e a arbitrariedade se manifestam na zona de desenvolvimento imediato, quanto o fato de que os conceitos científicos transformam e elevam ao nível superior os espontâneos, concretizando a zona de desenvolvimento imediato destes: porque o que a criança hoje é capaz de fazer em colaboração, amanhã estará em condições de fazer sozinha.

Assim, é preciso que os conceitos espontâneos tenham algumas funções na zona de desenvolvimento imediato, para que a criança consiga desenvolvê-las nos conceitos científicos. Mas vale lembrar que a aprendizagem só pode estimular o desenvolvimento porque este ainda não está completo. Seguindo esta lógica, a aprendizagem de conceitos novos só pode influenciar o desenvolvimento dos conceitos anteriormente existentes porque estes ainda não estão maduros. Embora em direções opostas, a aprendizagem do conceito científico ocorre junto com o desenvolvimento dos conceitos espontâneos, sendo possível que exerça uma influência transformadora sobre estes.

Para o autor, deste modo, um novo estágio é atingido pela transformação, nunca pela anulação do estágio anterior, pois, na passagem para o novo estágio, a criança não precisa reconstituir todas as palavras existentes na nova estrutura de significação. Cada conceito não precisa ser recriado, mas a nova estrutura adquirida por meio de poucos conceitos é transferida para todos os demais por força de leis estruturais. Ou seja, a criança forma uma nova estrutura “[...] primeiro com uns poucos conceitos, habitualmente readquiridos, por exemplo, no processo 
de aprendizagem; quando já domina essa nova estrutura, por força disto reconstrói e transforma a estrutura de todos os conceitos anteriores” (VYGOTSKY, 1934/2001, p. 374).

Embora o autor defina os conceitos científicos como aqueles aprendidos em situações formais de ensino, ele também menciona que os conceitos espontâneos são frutos da aprendizagem da criança:

[...] os conceitos espontâneos da criança, quando sua análise é levada até o fim, também são, até certo ponto, análogos aos conceitos científicos [...]. A aprendizagem não começa só na idade escolar, ela existe também na idade préescolar. Uma investigação futura provavelmente mostrará que os conceitos espontâneos da criança são um produto da aprendizagem pré-escolar tanto quanto os conceitos científicos são um produto da aprendizagem escolar (VYGOTSKY, 1934/2001, p. 388).

Uma outra questão levantada por Vygotsky (1934/2001) diz respeito ao fato de que os conceitos não são isolados como se apresentam nas investigações, pois, se os conceitos das crianças não tivessem vínculos e relações, não seria possível a vida complexa do seu pensamento, não seria possível qualquer operação intelectual que exigisse a correlação entre conceitos. Os conceitos só podem surgir, viver e se desenvolver no sistema de conceitos infantis. Assim, a essência do conceito pressupõe que a realidade por ele representada seja enriquecida, quando comparada com a percepção sensorial e com a contemplação da realidade, e este enriquecimento só pode ocorrer pelo estabelecimento de vínculos complexos entre os objetos que o conceito representa e o restante da realidade ${ }^{30}$.

Um aspecto que salienta as complexas relações nas quais os conceitos estão inseridos é a diferenciação entre significado e sentido. Para o autor, a linguagem interior opera preferencialmente com a semântica e não com a fonética da fala. Contudo, na semântica da

\footnotetext{
${ }^{30}$ Vygotsky, em sua teoria, discute mais detalhadamente as relações de generalidade entre os conceitos (aquelas estabelecidas entre conceitos mais gerais e mais específicos, dentro de pirâmides de conceitos - como no exemplo: planta, flor e rosa), o que o aproxima da visão clássica. Neste momento de seu texto, contudo, o autor dá a entender que os conceitos estabelecem relações muito mais complexas, com outros elementos da realidade. Este aspecto o aproxima da visão teórica dos conceitos.
} 
linguagem interior predomina o sentido e não o significado das palavras. O sentido engloba todos os elementos que a palavra desperta em nossa consciência, sendo o significado apenas um destes elementos. O sentido é mais dinâmico e mutável que o significado. A palavra incorpora ao seu sentido todo o contexto com o qual está entrelaçada, os conteúdos intelectuais, os afetivos, os momentos existentes na consciência e relacionados à palavra. Assim, parece-nos que, para o autor, os significados das palavras (os conceitos), não se encontram isolados, nem possuem relações apenas dentro de um sistema hierárquico, mas o indivíduo os relaciona a outros elementos, a sua própria compreensão do mundo e a sua estrutura interna.

Ao interagir com as pessoas, a criança se apropria gradativamente da linguagem, internalizando os seus significados. Visto que os significados expressos na linguagem são uma expressão também do modo de existência da sociedade, ao internalizar o significado, a criança também internaliza os conhecimentos de sua cultura, reelaborando-os, contudo, de acordo com suas experiências pessoais, interesses e necessidades. Os significados só adquirem uma natureza psicológica quando entram em contato com estes outros fatores. É nesta interação que os significados adquirem um sentido pessoal.

Como é possível perceber, a teoria de conceitos de Vygotsky se aproxima, em alguns aspectos, da visão clássica, enquanto que outros pressupostos a afastam desta visão. É possível citar as seguintes semelhanças com a visão clássica: são considerados conceitos verdadeiros aqueles formados pela abstração das características essenciais de uma classe de objetos, sendo tais características expressas nas definições dos conceitos; os conceitos são considerados dentro de um sistema hierárquico, tal como numa pirâmide taxonômica, na qual os mais gerais englobam os mais específicos; o desenvolvimento dos conceitos é compreendido como uma transformação global. 
Por outro lado, podemos arrolar algumas das idéias de Vygotsky que o aproximam da visão teórica, sendo elas: o autor considera que o pensamento do adulto não é totalmente constituído por conceitos clássicos, coexistindo complexos e conceitos potenciais; menciona que mesmo os adultos têm dificuldades para definir os conceitos; ao salientar que os sentidos também são vinculados às palavras, permite pensar que os conceitos estabelecem outras relações complexas, além das relações hierárquicas; também considera como conceitos aquelas noções formadas em situações cotidianas (conceitos espontâneos); considera que os conceitos espontâneos são formados com base nos atributos mais comuns, enquanto que os científicos são formados com base nos atributos essenciais.

Este último aspecto da teoria de Vygotsky assemelha-se aos resultados de pesquisas desenvolvidas a partir da visão teórica, os quais mostram que os conceitos das crianças pequenas estão mais ligados a exemplos específicos e à experiência imediata, categorizando os objetos e fenômenos com base em características que aparecem com maior freqüência (por exemplo, avó é uma senhora de cabelos brancos, que gosta de tricotar casaquinhos de lã); conforme se desenvolvem, as crianças passam a atentar para características menos superficiais, de modo que seus conceitos passam a ser baseados em princípios e definições (no caso do exemplo anterior, a criança considera que avó é a mãe de seu pai ou de sua mãe, mesmo que esta não tenha cabelos brancos e nem goste de tricotar). Na teoria de Vygotsky, este tipo de desenvolvimento ocorre no campo dos conceitos espontâneos, enquanto os conceitos científicos seguem outro caminho: iniciam-se com definições, sendo somente mais tarde ilustrados com exemplos concretos e associados a características não essenciais (KEIL, 1989). Também é possível refletir se a modificação de ênfase dos atributos característicos para os definidores, tal como observada no desenvolvimento dos conceitos espontâneos, não ocorreria por influência da aquisição de conceitos científicos, formados a partir de suas definições. 
Para Keil (1989), Vygotsky pode ter chegado perto da verdade, pois alguns tipos de conceitos são criados por convenção humana e podem ser quase totalmente definidos. Este autor, contudo, critica a idéia de que o desenvolvimento conceitual ocorra de maneira global para todos os conceitos. Esta idéia é compartilhada por outras teorias englobadas na concepção clássica, que também consideram a ocorrência de uma reorganização global da estrutura conceitual, em um dado ponto do desenvolvimento da criança, quando há uma reestruturação no modo como pensa sobre o mundo. Para a concepção teórica, ao contrário, as mudanças qualitativas no tocante ao desenvolvimento conceitual ocorrem em momentos diferentes para cada domínio de conhecimento.

Também é possível verificar que Vygotsky, apesar de mencionar que os conceitos estabelecem relações complexas, descreve apenas aquelas relações hierárquicas, próprias da visão clássica, não percebendo que os conceitos são também vinculados por meio de teorias ingênuas e crenças causais.

É de se compreender, porém, que a teoria de Vygotsky tenha muitos pontos em comum com a visão clássica, visto que, em sua época, esta era a única visão de conceitos existente, não sendo sequer questionada, mas implicitamente aceita como um pressuposto auto-evidente subjacente a todas as teorias de conceitos elaboradas até então (OLIVEIRA, 1994). Esta forma de considerar os conceitos só passou a ser identificada e criticada a partir da década de 70, muito depois que Vygotsky elaborou suas idéias sobre o desenvolvimento dos conceitos infantis.

Se levarmos em consideração tal situação, poderemos pensar, até mesmo, que as idéias do autor estavam à frente de seu tempo, trazendo uma semente do que um dia se tornaria um novo modo de ver os conceitos, a visão teórica. 


\subsection{Vygotsky e o desenvolvimento de crianças com deficiência}

Para Vygotsky (1983/1997), apesar das leis fundamentais do desenvolvimento serem as mesmas para todas as crianças, o desenvolvimento da criança que tem uma deficiência é qualitativamente, e não quantitativamente, diferente. Neste processo de desenvolvimento e de formação da personalidade da criança, a alteração orgânica desempenha um duplo papel: por um lado, a alteração limita o desenvolvimento, mas, precisamente porque cria certas dificuldades, estimula o avanço, a elaboração de uma compensação. São estas tendências as responsáveis pelas peculiaridades do desenvolvimento da criança com deficiência, criando formas de desenvolvimento diversas. O resultado deste processo de compensação pode ser de vitória, de derrota ou estar num grau de transição entre estes extremos, o que vai depender da gravidade da deficiência, da reserva compensatória do organismo e da educação, ou seja, da orientação consciente que é dada a este processo.

Porém, seja qual for a conclusão do processo de compensação, o desenvolvimento influenciado por uma deficiência constituirá sempre um processo (orgânico e psicológico) de criação e recriação da personalidade da criança, fundamentada na reorganização de todas as funções de adaptação. Por isso, ao avaliarmos uma criança com deficiência, não devemos levar em conta apenas o nível e a gravidade da deficiência, mas também considerar os processos substitutivos e compensatórios que surgem ao longo do seu desenvolvimento (VYGOTSKY, 1983/1997).

A compensação orgânica está presente em toda matéria viva, mas, no ser humano, é necessário considerar principalmente as compensações sociopsicológicas, que se concretizam nas relações com os outros e nas experiências nos diversos espaços da cultura. Desta forma, o desenvolvimento de uma criança com deficiência e seu funcionamento psicológico não dependem 
apenas de sua deficiência, mas também das condições concretas de desenvolvimento que o grupo social lhe oferece, que podem ser condições adequadas ou empobrecidas. Segundo Góes (2002, p. 99), “não é o déficit em si que traça o destino da criança. Esse ‘destino’ é construído pelo modo como a deficiência é significada, pelas formas de cuidado e educação recebidas pela criança, enfim, pelas experiências que lhe são propiciadas”.

A cegueira, por exemplo, não faz da criança uma pessoa com defeito, não é uma menosvalia ou uma enfermidade. A deficiência é um conceito social e a cegueira só se torna deficiência em certas condições sociais. “O déficit orgânico não pode ser ignorado, mas é a vida social que abre possibilidades ilimitadas de desenvolvimento cultural [...]”, tornando a deficiência histórica (GÓES, 2002, p. 100). Para Vygotsky (1983/1997), não podemos priorizar o déficit, deixando de lado a criança como um todo, pois, se nos focamos apenas na enfermidade da criança, deixamos de perceber a sua saúde.

Segundo Braga (1986, 1995), estas considerações de Vygotsky, levaram a uma mudança na forma de olhar para a criança com deficiência e de considerar o seu desenvolvimento, influenciando diretamente na prática terapêutica e pedagógica. Pois, se percebermos que o desenvolvimento desta criança é diferente e não inferior, poderemos perceber também suas qualidades e elaborar métodos distintos de tratamento, visando ajudar a criança a encontrar caminhos alternativos e compensatórios para o seu desenvolvimento, ao invés de tentarmos aproximá-la do que consideramos normal.

O desenvolvimento da criança com deficiência deve ser tomado em sua dinâmica, numa visão prospectiva, de modo que sua educação privilegie suas potencialidades e talentos. As metas educacionais devem, então, ser iguais para todas as crianças. A criança com deficiência pode precisar de mais tempo ou de procedimentos especiais, mas aprenderá o mesmo e receberá a mesma preparação para o futuro. Isso não quer dizer que ela terá, certamente, capacidades iguais, 
mas quer dizer que os limites não devem ser determinados a priori e suas metas não devem ser subestimadas (GARCÍA; BEATÓN, 2004; GÓES, 2002; VYGOTSKY, 1983/1997).

Vygotsky (1983/1997) ilustra esta idéia com a seguinte situação: a criança com deficiência mental depende muito de suas experiências concretas, de modo que, por conta própria, desenvolverá pouco o pensamento abstrato. O que se percebe, nestes casos, é que a escola se utiliza apenas de métodos visuais diretos, materiais concretos, acreditando que assim facilitará a aprendizagem. Contudo, esta postura serve de obstáculo para o desenvolvimento do pensamento abstrato, pois não são dadas oportunidades para que a criança se desenvolva neste sentido. A escola não só deve adaptar-se às dificuldades desta criança, mas também deve ajudá-la a superálas. Deve-se respeitar a fase em que a criança se encontra e o seu modo de pensar, mas não se deve limitar a priori sua aprendizagem, na crença de que seria incapaz de compreender.

Ao contrário, no cuidado da criança com deficiência, devemos permitir que ela se engaje em atividades cada vez mais complexas, com a ajuda do adulto ou de companheiros mais avançados, permitindo que ela avance em seu desenvolvimento (GARCÍA; BEATÓN, 2004).

Esta idéia está relacionada ao conceito de zona de desenvolvimento proximal, que, segundo Braga (1995), também tem repercussões no tratamento e na educação da criança que apresenta uma lesão cerebral.

Uma vez que a zona de desenvolvimento proximal hoje, será o nível de desenvolvimento real amanhã, a avaliação do desenvolvimento de uma criança com paralisia cerebral deve considerar não só o que a criança faz sem ajuda como também o que ela é capaz de realizar quando auxiliada (p. 39).

Além desta importância para a avaliação e para o tratamento da criança com deficiência, o conceito de zona de desenvolvimento proximal é também importante por possibilitar refletir sobre o papel do adulto no desenvolvimento da criança com deficiência. Pois, para a criança com paralisia cerebral, a relação estabelecida com outras pessoas pode ser um elemento fundamental 
para o seu desenvolvimento, uma vez que é nesta relação que a criança “[...] poderia, gradualmente, a partir de ações partilhadas, aumentar o grau de controle de suas ações” (BRAGA, 1995, p. 58).

Algumas crianças com deficiência apenas conseguem realizar suas tarefas de vida diária (alimentação, troca de roupa, higiene pessoal, etc.), suas atividades escolares e brincadeiras com a ajuda de outras pessoas, e o conceito de zona de desenvolvimento proximal possibilita considerar aquilo que a criança é capaz de fazer com ajuda como integrante do seu processo de desenvolvimento, o que repercute diretamente na avaliação, na educação e no tratamento desta criança.

\subsection{Justificativa e objetivo do trabalho}

Embora diversos autores sugiram a importância das situações espontâneas e das atividades lúdicas para vários aspectos do desenvolvimento da criança, são escassos, em nosso meio, os trabalhos a respeito do desenvolvimento cognitivo de crianças com alterações motoras. Mais raros ainda são os trabalhos que investigam a formação de conceitos por crianças com seqüelas de paralisia cerebral. Takatori (1999) também menciona que são poucas as pesquisas que abordam o brincar e a criança com deficiência física.

Rosenbaum (1998) afirma que a brincadeira motora em crianças com deficiência é uma oportunidade negligenciada para pesquisas. De acordo com o autor, além da importância óbvia da função motora para o desenvolvimento físico, a motricidade cumpre papéis vitais no desenvolvimento cognitivo e social. Assim sendo, pesquisas nesta área poderiam ter um impacto profundo nas suposições a partir das quais nossas intervenções com crianças com deficiência estão fundamentadas. Além disso, os estudos sobre o desenvolvimento de crianças com 
desordens na função motora trazem uma oportunidade, ainda inexplorada, para entender a importância da função motora para o desenvolvimento de todas as crianças.

Em suma, embora se admita a importância da experiência motora no desenvolvimento cognitivo, pouco foi estudado a respeito de como se dá o desenvolvimento de crianças que têm sua ação limitada por uma incapacidade motora e, menos ainda, sobre a efetividade das técnicas de intervenção utilizadas com esta clientela.

A autora deste trabalho acredita que esta pesquisa poderá contribuir para uma melhor compreensão das necessidades apresentadas por crianças com seqüelas de paralisia cerebral e auxiliar na prática de profissionais que lidam com o desenvolvimento neuropsicomotor e com o processo de inclusão escolar e social de crianças com deficiência. Além disso, uma melhor compreensão sobre como os conceitos são formados, poderá auxiliar na preparação dos professores e nas suas adaptações curriculares, possibilitando uma resposta mais eficaz às necessidades de todos os alunos, evitando, assim, fracassos escolares ou encaminhamentos desnecessários de crianças para estruturas de ensino segregadas.

Assim, em face da relevância do tema e da escassez de pesquisas com crianças com seqüelas de paralisia cerebral, buscou-se, com este estudo exploratório, investigar a influência de atividades lúdicas no processo de formação de conceitos básicos por esta população. 


\section{CAPÍTULO 5}

\section{MÉTODO}

\subsection{Considerações gerais}

No presente trabalho, optou-se por realizar uma pesquisa qualitativa. Esta escolha deveuse ao fato de que este tipo de abordagem permite, além de considerar as características de cada criança participante, articular os diferentes fatores envolvidos neste trabalho, quais sejam: o desenvolvimento cognitivo de crianças com paralisia cerebral, a importância do oferecimento de experiências lúdicas para tais crianças e o processo de formação de conceitos básicos.

Era de fundamental importância considerar as características individuais das crianças participantes, uma vez que a paralisia cerebral pode se manifestar de diferentes maneiras ${ }^{31}$, acometendo as funções da criança em diferentes graus. Além dos aspectos relacionados à lesão neurológica, outras características próprias da criança e de sua família também fazem com que a deficiência seja encarada de maneiras diversas, influenciando no desenvolvimento global e na provisão de oportunidades para a criança com paralisia cerebral. Deste modo, tornou-se difícil a seleção de casos semelhantes, que pudessem ser analisados de maneira global, como costuma ser feito em pesquisas quantitativas.

De acordo com Rey (2005), a pesquisa qualitativa é caracterizada pela construção de um modelo teórico por meio da significação da informação produzida, que não está fragmentada em resultados parciais obtidos pelos instrumentos utilizados. Ou seja, neste tipo de pesquisa, o dado não é tido como um fim em si mesmo, mas seu valor vem do significado que lhe é atribuído.

\footnotetext{
${ }^{31}$ Além do comprometimento motor, que pode ocorrer em diferentes graus de severidade e pode acometer diferentes partes do corpo da criança, também pode haver a associação de alterações cognitivas, comportamentais e/ou sensoriais, fazendo com que cada criança com paralisia cerebral tenha características peculiares.
} 
Visto que o significado é sempre uma produção humana, não estando expresso no próprio dado, o conhecimento não é tido como uma apropriação linear da realidade, mas como uma construção.

A pesquisa qualitativa, segundo Lüdke e André (1986) e Triviños (1987), apresenta os seguintes aspectos básicos ${ }^{32}$ : tem o ambiente natural como fonte direta de dados e o pesquisador como instrumento-chave, supondo o contato direto do pesquisador com o ambiente e a situação investigada; é descritiva, portanto, o pesquisador deve aproveitar o maior número possível de elementos de informação, para que possa descrever com o máximo de detalhes as situações ocorridas e as pessoas envolvidas no fenômeno estudado; a preocupação com o processo é maior do que com o produto; os dados tendem a ser analisados indutivamente ${ }^{33}$; os significados atribuídos às coisas pelas pessoas é o foco principal do investigador.

Para Triviños (1987), na pesquisa qualitativa, em geral, segue-se a mesma rota da pesquisa quantitativa de caráter positivista (por exemplo, delimitação do problema, pesquisa da literatura, definição das hipóteses e das variáveis, coleta e análise dos dados, discussão e conclusão). Contudo, na pesquisa qualitativa não há uma exigência de seguir uma seqüência tão rígida, de modo que uma pesquisa desenvolvida com base nesta abordagem pode apresentar as seguintes características: a coleta e a análise dos dados podem ocorrer ao mesmo tempo; algumas hipóteses podem ser excluídas ou acrescentadas no decorrer do trabalho; a maior parte da investigação teórica ocorre ao longo do estudo; há pouco empenho por definir operacionalmente as variáveis, podendo estas serem muitas e apenas descritas. Quanto à amostra, esta pode ser escolhida aleatoriamente ou não; também não há exigência quanto ao uso da estatística para determinar a sua representatividade. Do mesmo modo, fica à margem o estabelecimento do

\footnotetext{
${ }^{32}$ Ambos os textos, no que se refere aos aspectos básicos da pesquisa qualitativa, citam: BOGDAN, R.; BIRTEN, S.K. Qualitative research for education: an introduction to theory and methods. Boston: Allyn and Bacon, 1982. 253 p.

${ }^{33} \mathrm{O}$ método indutivo é uma aproximação dos fenômenos que vai das constatações mais particulares às leis e teorias, ou seja, parte do particular, sendo a generalização um produto posterior do trabalho de coleta de dados particulares (GIL, 1994; MARCONI; LAKATOS, 2003).
} 
coeficiente de fidedignidade dos instrumentos empregados. Assim sendo, neste referencial, o pesquisador tem liberdade teórico-metodológica, podendo, ao mesmo tempo, empregar técnicas de pesquisa quantitativa e qualitativa.

Neste mesmo sentido, Rey (2005) menciona que não deve haver dicotomia entre a coleta e a elaboração dos dados, pois, quando se separa o dado de seu cenário, perdem-se aspectos essenciais de seu significado. Na pesquisa qualitativa, segundo este autor, não existem exigências a priori sobre a quantidade nem os tipos de instrumentos, sendo esta escolha influenciada pelas necessidades encontradas no curso da pesquisa.

Visto que a pesquisa qualitativa pode combinar diferentes métodos e se utilizar de diferentes instrumentos para a coleta de dados (GIL, 1994; REY, 2005; TRIVIÑOS, 1987), podendo, inclusive, empregar procedimentos da pesquisa quantitativa, neste trabalho optou-se por combinar três delineamentos ${ }^{34}$. Inicialmente, objetivando uma aproximação ao tema, bem como o conhecimento do material já acumulado sobre o assunto, foi realizado um levantamento bibliográfico. Este levantamento, que foi desenvolvido nas bases de dados MEDLINE (de 1979 a 2006), LILACS, SCIELO e BVS Psi (de 1963 a 2006), bem como nos acervos de bibliotecas da Universidade de São Paulo, Universidade Estadual de Campinas, Universidade Federal do Espírito Santo, Escola Paulista de Medicina e Pontifícia Universidade Católica de São Paulo ${ }^{35}$, estendeu-se por todo o período da pesquisa, dado a necessidade de novos referenciais teóricos para auxiliar na compreensão dos dados. Além disso, visando avaliar a formação de conceitos

\footnotetext{
${ }^{34}$ Gil (1994) considera a pesquisa bibliográfica, a pesquisa experimental e o estudo de caso, entre outros, como delineamentos de pesquisa. Delineamento diz respeito ao planejamento, ao método empregado; contudo, a classificação das pesquisas quanto ao delineamento não é rígida, mas apenas se aproxima da realidade de cada investigação. A observação e o questionário, que serão mencionados mais adiante, são chamados de técnicas ou procedimentos de coleta de dados, não sendo estes específicos de nenhum tipo de delineamento.

${ }^{35}$ Nos levantamentos realizados nas bases de dados e nos arquivos das bibliotecas, foram utilizadas, individual ou conjuntamente, as seguintes palavras-chave: formação, conceito, criança, paralisia, cerebral, desenvolvimento, Vygotsky, Boehm, BTBC, deficiência, brincar, brincadeira, terapia, ocupacional. Dentre os trabalhos encontrados, foram incluídos, nesta pesquisa, aqueles escritos em Português, Inglês, Espanhol ou Francês.
} 
pelas crianças com deficiência por meio das atividades lúdicas, foi utilizado um procedimento semelhante aos empregados em investigações experimentais. Por outro lado, visto a heterogeneidade das crianças envolvidas na pesquisa, bem como a importância atribuída mais ao processo do que ao produto dos atendimentos, optou-se por realizar estudos de casos que possibilitassem observar a influência das brincadeiras sobre o desenvolvimento das crianças participantes.

De acordo com Gil (1994), embora o delineamento experimental tenha surgido em pesquisas de cunho positivista, sendo típico das ciências naturais, também pode ser utilizado nas ciências humanas. O autor exemplifica que, na pedagogia, este delineamento pode ser utilizado para avaliar o efeito das técnicas de ensino sobre o aprendizado, ou para estudar processos cognitivos. As definições de investigação experimental feitas por Gil (1994), Marinho (1980) e Pádua (2004) podem auxiliar na compreensão do estudo realizado neste trabalho. Segundo estes autores, na pesquisa experimental, o investigador manipula uma ou mais variáveis independentes, em condições de adequado controle, com o objetivo de observar e interpretar as modificações que possam ocorrer em uma variável dependente. Assim sendo, nesta pesquisa, uma variável independente foi manipulada (a realização de brincadeiras que envolvem conceitos), visando causar modificações em uma variável dependente (a aprendizagem de conceitos básicos por crianças com paralisia cerebral). Neste caso, foi utilizado o seguinte modelo experimental: préteste/treinamento/pós-teste para um único grupo, ou seja, a variável dependente (domínio de conceitos básicos) foi medida antes e depois da aplicação da variável independente (brincadeiras que envolvem estes conceitos), num mesmo grupo de crianças com paralisia cerebral.

Conforme afirmado por Rey (2005), o experimento é um instrumento que facilita o acesso a indicadores de difícil expressão por outras vias e representa um modelo o mais próximo possível das condições do desenvolvimento de uma atividade na vida cotidiana. Assim sendo, são 
aqui reproduzidas situações que podem ocorrer em atendimentos de Terapia Ocupacional, qual seja, o uso da atividade lúdica no tratamento de crianças com paralisia cerebral. Contudo, visto que se trata de uma pesquisa qualitativa, não há, neste trabalho, uma grande preocupação com a operacionalização das variáveis nem com o controle de variáveis estranhas (aquelas que podem interferir no resultado da pesquisa). Além disso, é dada maior ênfase aos fatos que ocorreram no processo da pesquisa do que aos seus resultados propriamente ditos.

Por este motivo, a realização de estudos de casos possibilitou captar, para além dos resultados obtidos nos testes, as características pessoais de cada criança, seus interesses, capacidades e dificuldades, a sua interação com a pesquisadora, bem como suas possibilidades de participação nas atividades lúdicas escolhidas.

Triviños (1987) define o estudo de caso como uma categoria de pesquisa cujo objeto é uma unidade que se analisa profundamente. De acordo com Yin (2005), o estudo de caso é uma investigação empírica que investiga um fenômeno dentro de seu contexto de vida real, sendo especialmente importante quando queremos lidar com as condições contextuais, acreditando que estas podem ser pertinentes ao fenômeno em estudo. Estes autores, assim como Alves-Mazzotti e Gewandsnajder (1998), concordam que a unidade de análise do estudo de caso pode ser um sujeito, um grupo ou subgrupo de sujeitos, bem como uma determinada situação. A complexidade do estudo de caso também pode ser variável.

Para Pádua (2004), o estudo de caso não realiza a análise do indivíduo por completo, mas é uma tentativa de abranger as características mais importantes relacionadas ao tema pesquisado. Assim, não se objetiva, aqui, realizar um levantamento de toda a trajetória de vida e de todos os aspectos característicos das crianças participantes, mas apenas daqueles aspectos importantes para a análise do tema em questão. 
Os dados coletados para os estudos de caso podem, segundo Yin (2005), ser baseados em muitas fontes de evidências, tais como documentação, registros em arquivos, entrevistas, observação direta, observação participante e artefatos físicos. Todos os meios de coleta de dados da pesquisa quantitativa também podem ser usados, mas, no estudo de caso, deve haver atenção especial ao informante, à participação de um mesmo observador e às anotações de campo (TRIVIÑOS, 1987).

A utilização de diferentes recursos para a coleta de dados permite a acumulação de maior variedade de informações, bem como a produção de informações mais confiáveis. Desta forma, nos estudos de caso realizados nesta pesquisa, além da inclusão dos resultados dos testes, também se optou por utilizar dois questionários respondidos pelos cuidadores (pais ou responsáveis pelas crianças), visando coletar dados a respeito do desenvolvimento e do cotidiano de cada criança. Para reunir informações acerca da participação e da evolução de cada criança no decorrer da pesquisa, utilizou-se também a técnica da observação participante.

A observação utilizada como técnica de coleta de dados pode ser classificada como estruturada, quando os comportamentos a serem registrados e a forma de registro são préestabelecidos, ou não-estruturada, quando os comportamentos são observados e relatados da forma como ocorrem. A observação também pode ser natural, em que os participantes não percebem a atuação do observador, ou idealizada, em que o observador cria situações e interfere de forma participativa. Este último tipo de observação costuma ser denominado observação participante, que ocorre quando o observador se envolve com o seu objeto de pesquisa, passando a fazer parte da situação observada. Assim, na observação participante, o pesquisador não é apenas um observador passivo, mas pode assumir uma variedade de funções e pode participar dos eventos que estão sendo estudados (ALVES-MAZZOTTI; GEWANDSNAJDER, 1998; CERVO; BERVIAN, 2002; PÁDUA, 2004; YIN, 2005). 
Embora a observação participante seja associada à idéia de imersão total do pesquisador no contexto observado, o nível de sua participação pode ser bastante variável ${ }^{36}$. Assim, o pesquisador pode assumir desde um papel de indivíduo do grupo até, por exemplo, um papel de chefia, interferindo ou não no curso dos acontecimentos. Além disso, a exposição de seu papel de pesquisador pode ou não ser declarada desde o início da pesquisa (YIN, 2005). No caso desta investigação, a pesquisadora assumiu o papel de terapeuta, realizando intervenções num processo terapêutico; o seu duplo papel de terapeuta e pesquisadora foi explicitado desde o início, tanto para os responsáveis quanto para as crianças.

Nesta pesquisa, a observação participante foi do tipo não-estruturado, de modo que todas as intervenções e observações foram registradas na seqüência em que ocorriam, em forma de diário de campo. Estas anotações eram realizadas após cada dia de atendimento, no menor intervalo de tempo possível, visando descrever as situações com grande riqueza de detalhes.

De acordo com Triviños (1987), as anotações de campo, num sentido restrito, podem ser entendidas como todas as observações e reflexões realizadas sobre expressões verbais e ações dos sujeitos, primeiro descrevendo-as e, em seguida, fazendo comentários sobre as mesmas. O autor também fala da importância dos registros das reflexões do investigador, que são as primeiras buscas espontâneas de significados e explicações. Segundo ele, há dois tipos de anotações de campo: as descritivas (que apenas descrevem as situações) e as reflexivas. Neste caso, embora descreva determinados acontecimentos, a mente do pesquisador também está envolvida no processo da pesquisa como um todo. De acordo com Pádua (2004), além de coletar dados para a

\footnotetext{
${ }^{36}$ Alguns autores, tais como Nogueira (1975), mencionam a observação participante como se esta fosse utilizada apenas na área social, em pesquisas que visam conhecer a vida de determinadas populações. Outros autores, como Gil (1994) e Lüdke e André (1986), confirmam que esta técnica surgiu com trabalhos de antropólogos, sendo atualmente bastante utilizada na pesquisa participante (na qual há um envolvimento mútuo do pesquisador com os participantes, no sentido de encontrarem soluções para um problema que o grupo vivencia). Estes autores, contudo, não consideram a técnica da observação participante como exclusiva destes tipos de pesquisa, postura esta que também é demonstrada por outros autores (ALVES-MAZZOTTI; GEWANDSNAJDER, 1998; CERVO; BERVIAN, 2002; YIN, 2005).
} 
análise final, o diário de pesquisa permite que se faça uma retrospectiva do trabalho realizado e possibilita a percepção de elementos novos que não haviam sido levados em conta anteriormente.

O diário de campo utilizado nesta pesquisa é do tipo reflexivo, pois, além de terem sido narrados todos os acontecimentos observados, também foram registradas as reflexões tecidas no decorrer dos atendimentos. Após o término do período de intervenção, cada caso foi analisado individualmente e, em seguida, todos os casos foram analisados em conjunto. Triviños (1987) e Yin (2005) mencionam esta possibilidade de que se estabeleçam comparações entre casos individuais, realizando-se, assim, um estudo comparativo de casos ou uma síntese de casos cruzados.

Em suma, esta pesquisa qualitativa adotou os seguintes delineamentos: pesquisa bibliográfica; avaliação da influência da brincadeira na formação de conceitos pelas crianças participantes, o qual seguiu o modelo experimental de pré-teste, treinamento e pós-teste; estudos de casos, nos quais foram utilizados os resultados obtidos por cada criança no pré-teste e no pósteste, os dados de dois questionários respondidos por seus cuidadores e as informações do diário de campo, obtidas por meio da técnica da observação participante. Durante as sessões de brincadeiras, a pesquisadora assumiu o papel de observadora e terapeuta, realizando intervenções com o objetivo de favorecer o desenvolvimento de conceitos pelas crianças participantes.

\subsection{Participantes}

Os sujeitos desta pesquisa são crianças com seqüelas de paralisia cerebral, com idades entre seis anos e 11 meses e 10 anos e 11 meses, freqüentadoras de três instituições de reabilitação, sendo duas situadas na cidade de São Paulo - SP e a outra, na cidade de Vitória ES. 
Foram excluídas desta pesquisa as crianças que apresentavam deficiência mental moderada ou profunda já diagnosticada e/ou deficiência visual e/ou auditiva que impossibilitasse(m) a comunicação e a participação nas tarefas. Para a determinação da inclusão das crianças pré-selecionadas, ou seja, daquelas que não se enquadravam nos critérios de exclusão acima descritos, foi utilizado como um novo critério o resultado dos itens de instrução do Teste de Conceitos Básicos de Boehm adaptado, de modo que foram incluídas apenas as crianças que responderam adequadamente a quatro dentre os seis itens referentes a objetos do dia a dia.

Foram avaliadas 12 crianças com seqüelas de paralisia cerebral, e, em função dos critérios estabelecidos, oito crianças foram incluídas na pesquisa ${ }^{37}$. Visto que uma das crianças deixou de freqüentar a instituição de reabilitação no período dos atendimentos, um total de sete crianças participou efetivamente da pesquisa, sendo duas meninas e cinco meninos. Quanto à classificação do tipo de paralisia cerebral, três das crianças participantes apresentam quadro de diparesia espástica, duas apresentam tetraparesia espástica e duas, tetraparesia atetóide com componente espástico. As características de cada criança participante estão descritas no Quadro 1, no que se refere à idade na data da avaliação, diagnóstico, sexo e local (estado em que reside).

Quadro 1. Características das crianças participantes da pesquisa.

\begin{tabular}{|c|l|l|l|c|}
\hline Sujeito & Idade & Diagnóstico & Sexo & Local \\
\hline N. & 7 anos e 5 meses & Tetraparesia espástica & Masculino & SP \\
\hline F. & 6 anos e 11 meses & Diparesia espástica & Masculino & SP \\
\hline B. & 7 anos e 5 meses & Tetraparesia espástica & Feminino & SP \\
\hline FR. & 10 anos e 11 meses & Diparesia espástica & Masculino & SP \\
\hline V. & 9 anos e 3 meses & Tetraparesia atetóide & Masculino & ES \\
\hline E. & 10 anos & Diparesia espástica & Masculino & ES \\
\hline L. & 10 anos e 2 meses & Tetraparesia atetóide & Feminino & ES \\
\hline
\end{tabular}

\footnotetext{
${ }^{37}$ Visto que a realização do teste de conceitos e a possibilidade de participar da pesquisa criaram uma grande expectativa nos pais e nas crianças, a pesquisadora optou por realizar, com as quatro crianças avaliadas e excluídas da pesquisa, sessões de Terapia Ocupacional com o uso da brincadeira. Assim, estas crianças foram acompanhadas pelo mesmo período e com a mesma freqüência em que foram acompanhadas as crianças da pesquisa, contudo os objetivos variavam de acordo com as necessidades de cada uma delas.
} 
Para cada criança selecionada, um cuidador (mãe, pai ou outro adulto responsável pela criança) participou da pesquisa, respondendo a dois questionários, sendo um a respeito das atividades lúdicas comumente realizadas pela criança e outro a respeito do desenvolvimento da criança e de sua participação na família.

\subsection{Material}

\subsubsection{Teste de Conceitos Básicos de Boehm}

O instrumento utilizado no pré-teste e no pós-teste é uma adaptação do Teste de Conceitos Básicos de Boehm (BTBC). Este teste foi escolhido por incluir conceitos básicos considerados fundamentais para as atividades cotidianas e escolares, bem como por ser um material de fácil aplicação, visto que a criança é solicitada a escolher, dentre três figuras, a figura que exemplifica um determinado conceito.

O teste original se destina a avaliar o domínio de conceitos básicos por crianças da préescola, $1^{\text {a }}$ e $2^{\mathrm{a}}$ séries do ensino fundamental. Seus resultados podem ser utilizados, segundo Boehm (1971), para identificar crianças com dificuldades na formação de conceitos e/ou para identificar os conceitos que não estão dominados por um grupo específico de crianças e que, portanto, precisam ser mais bem trabalhados.

Para a seleção dos conceitos que seriam utilizados no teste, Boehm (1971) procedeu, sucintamente, da seguinte forma: realizou uma seleção de conceitos utilizados em disciplinas curriculares nas áreas de leitura, aritmética e ciência, da pré-escola e $1^{\text {a }}$ série; os conceitos selecionados foram transformados em itens de múltipla escolha, representados por meio de 
desenhos, e estes foram testados em grupos de crianças da pré-escola, $1^{\mathrm{a}}$, $2^{\mathrm{a}}$ e $3^{\mathrm{a}}$ séries de escolas de um estado dos Estados Unidos da América. O pré-teste visava identificar itens que apresentavam ambigüidades ou falta de clareza nas expressões utilizadas, bem como os conceitos respondidos corretamente por quase todos os alunos examinados (98\% ou mais); estes itens foram excluídos, mantendo-se apenas os não ambíguos e os não extremamente familiares às crianças avaliadas. A ordenação destes conceitos, nos cadernos do teste, foi feita com base no grau de dificuldade apresentado.

As crianças da $3^{\mathrm{a}}$ série, em sua grande maioria, não tiveram nenhuma dificuldade na realização do teste, o que fez a autora contra-indicar o teste para crianças a partir deste nível de escolarização. Os testes de padronização foram realizados com crianças da pré-escola, $1^{\text {a }}$ e $2^{\text {a }}$ séries, em 16 cidades de diferentes regiões dos Estados Unidos da América.

Boehm (1971) agrupou os conceitos selecionados em quatro categorias: espaço, quantidade, tempo e mistura, sendo que a categoria de mistura indica conceitos que não pertencem especificamente a nenhuma categoria do BTBC.

Os 50 conceitos considerados básicos por Boehm são os seguintes:

1) Espaço: no alto; atravessar; afastado; perto; dentro; meio; o mais afastado; em volta; acima; entre; o mais perto; ponta; atrás; em fila; centro; lado; debaixo (sob); lado direito; frente; sobre; separadas; à esquerda; em ordem.

2) Quantidade: alguns, não muitos; poucos; a mais larga; mais; inteiro; segundo; vários; quase; metade; tanto quanto; nem o primeiro nem o último; tamanho médio; zero; cada; um par; o mesmo; terceiro; menos.

3) Tempo: depois; começar; nunca; sempre.

4) Mistura: diferente; outro; iguais; semelhante; pular. 
Para fins desta pesquisa, foram selecionados 15 conceitos, sendo cinco de cada domínio conceitual, com exceção da categoria de mistura, por não representar um domínio conceitual específico.

Para orientar a escolha dos 15 conceitos utilizados nesta pesquisa, foram consultados 24 professores da pré-escola, $1^{\text {a }}$ e $2^{\mathrm{a}}$ séries do primeiro grau, de diferentes escolas do ensino regular de São Paulo, Rio de Janeiro e Espírito Santo. Aos professores foram apresentados 24 conceitos, sendo oito de cada domínio conceitual, excluindo-se a categoria de mistura. Alguns conceitos foram excluídos, inicialmente, por serem ambíguos e/ou por terem gerado dúvidas na aplicação do BTBC, na pesquisa realizada com crianças com Síndrome de Down e com crianças sem comprometimento, descrita no subitem 3.2, do Capítulo 3 deste trabalho. Por outro lado, alguns conceitos que não faziam parte do teste original foram incluídos na pesquisa, devido à necessidade de substituir os conceitos excluídos.

A ordem de apresentação dos conceitos aos professores, determinada por sorteio, foi a seguinte: menos, metade, centro, um par, separadas, vários, à noite, logo, muitos, entre, agora, lado direito, em volta, sobre, inteiro, debaixo, quase, depois, tamanho médio, imediatamente, nunca, cedo, longe, lento. Os professores foram solicitados a indicar se consideravam cada conceito fácil, médio ou difícil para crianças entre 6 e 8 anos de idade.

Foram calculadas as porcentagens de respostas em cada nível de dificuldade para cada conceito. Quando um professor apresentava uma resposta em branco ou duas alternativas eram marcadas para um mesmo conceito, estas respostas eram desconsideradas, embora as demais respostas deste professor fossem computadas normalmente.

A partir das respostas dos professores, foram escolhidos três conceitos considerados médios, um considerado fácil e um considerado difícil, para cada domínio conceitual, totalizando 15 conceitos. Foram inicialmente selecionados os conceitos com as maiores porcentagens de 
respostas no nível médio. Em seguida, utilizando-se do mesmo critério, foram escolhidos os conceitos no nível fácil e, finalmente, no nível difícil. Apenas o conceito "tamanho médio" foi considerado difícil pela maioria dos professores, com 50\% das respostas no nível difícil, 20,8\% no nível fácil e 29,2\% no nível médio. Portanto, para a escolha de conceitos considerados difíceis dentro dos domínios conceituais de espaço e tempo, o primeiro critério utilizado foi a ocorrência de empate entre os níveis médio e difícil, enquadrando-se neste critério o conceito de "lado direito”, com 50\% de respostas no nível médio e 50\% no nível difícil. Visto que nenhum conceito do domínio de tempo enquadrou-se nos critérios anteriormente estipulados, optou-se por escolher um conceito considerado médio, mas que tivesse obtido o maior número de respostas no nível difícil, sendo selecionado, assim, o conceito “logo”, que obteve 30,4\% de respostas no nível fácil, 43,5\% no nível médio e 26,1\% no nível difícil. Ainda neste domínio conceitual, uma vez que o conceito "agora” já havia sido selecionado para a pesquisa, optou-se por substituir o conceito “imediatamente”, muito semelhante a ele, pelo conceito “depois”, que obteve $50 \%$ das respostas no nível médio.

Assim, os conceitos selecionados para esta pesquisa foram os seguintes:

1) Quantidade: metade (62,5\% de respostas no nível médio), quase (62,5\% no nível médio), menos (50\% no nível médio), muitos (79,2\% no nível fácil) e tamanho médio (50\% no nível difícil).

2) Espaço: em volta (58,3\% de respostas no nível médio), entre (50\% no nível médio), centro (47,8\% no nível médio), debaixo (87\% no nível fácil) e lado direito (50\% no nível difícil).

3) Tempo: cedo (62,5\% de respostas no nível médio), depois (50\% no nível médio), nunca (45,4\% no nível médio), agora (91,7\% no nível fácil) e logo (26,1\% no nível difícil).

Visto que o BTBC destina-se originalmente a crianças sem deficiência, os desenhos do teste, bem como os dos itens de instrução, foram adaptados aos sujeitos desta pesquisa. Assim, 
levando-se em consideração que muitas crianças com paralisia cerebral apresentam também algum tipo de alteração na função visual, os desenhos do teste foram ampliados numa proporção de $75 \%$ e coloridos, visando facilitar sua visualização e percepção. Alguns desenhos foram modificados na tentativa de simplificá-los, facilitando a compreensão dos mesmos. Outros foram criados, visto que alguns dos conceitos utilizados nesta pesquisa não faziam parte do teste original. Foram feitas algumas alterações nas questões originais do teste, quando estas apresentavam ambigüidades ou não se adequavam à realidade dos sujeitos desta pesquisa.

Após feitas as alterações, o teste adaptado foi aplicado a um grupo de 14 crianças do último ano do ensino infantil (pré-escola), visando verificar se os desenhos e as questões modificadas apresentavam algum erro ou ambigüidade. Estas crianças tinham uma idade média de cinco anos e seis meses. Nesta etapa, foram incluídas apenas crianças que não apresentavam histórico de alterações no desenvolvimento, sendo desconsiderados os resultados de uma criança que realizava tratamento com terapeuta ocupacional devido a suspeitas de déficit de atenção e hiperatividade.

As respostas das crianças mostraram que, embora não dominassem por completo todos os conceitos do teste, o que era esperado para esta faixa etária, conseguiram compreender de maneira satisfatória às questões e aos desenhos, mostrando que estes estavam adequados aos objetivos do teste. Certas crianças, contudo, questionaram algumas formas das perguntas, o que levou a alterações nas questões. Como exemplo destes questionamentos, podemos citar: quando a pesquisadora perguntou qual menino chegaria mais cedo à escola, algumas crianças disseram que havia uma menina no desenho, o que fez com que, nesta pergunta, a palavra "menino" fosse substituída pela palavra “criança”. 


\subsubsection{Questionários para os cuidadores}

Foram desenvolvidos dois questionários que foram respondidos pelos pais ou responsáveis pelas crianças participantes.

Para a avaliação das atividades lúdicas realizadas comumente pelas crianças, optou-se por utilizar uma adaptação do Histórico Lúdico (TAKATA, $1974^{38}$ apud BRYZE, 2002). O Histórico Lúdico é um questionário qualitativo e aberto, desenvolvido com base na premissa de que a recreação e o desenvolvimento são entrelaçados, de modo que o planejamento do tratamento deva ser pautado numa avaliação dos comportamentos passados e presentes da criança. O Histórico Lúdico busca informações acerca das experiências lúdicas, interações e oportunidades da criança ao longo da sua vida, indagando a qualidade e a quantidade de suas brincadeiras.

Para estruturar o questionário para os cuidadores, optou-se por não utilizar o Histórico Lúdico na íntegra, visto que o objetivo era investigar a qualidade e a quantidade de brincadeiras realizadas pela criança apenas na fase na qual se encontrava, bem como descobrir suas preferências e dificuldades. Por este motivo, foram excluídos os itens que correspondem às experiências lúdicas anteriores, à descrição e à prescrição de atividades recreativas. Permaneceram os itens correspondentes à identificação da criança e ao Exame Lúdico Atual, no qual são investigadas as brincadeiras que a criança realiza, os materiais que utiliza, como brinca, com quem, onde, por quanto tempo e em que momentos do dia. Visando adequar a avaliação ao vocabulário dos cuidadores e aos objetivos desta pesquisa, algumas palavras também foram modificadas; quais sejam: na pergunta “Com quem a criança brinca?”, o item “adversários”, foi substituído por “outras crianças”; a pergunta “Qual tipo de atividade recreativa é preferida ou

\footnotetext{
38 TAKATA, N. Play as prescription. In: REILLY, M. Play as exploratory learning. Beverly Hills, CA: Sage Publications, 1974.
} 
evitada?” foi modificada para “Qual tipo de brincadeira é preferida e qual tipo é evitada?”. No subitem “materiais”, da questão “Com o que a criança brinca?”, foram incluídos alguns exemplos, visando facilitar o entendimento do que se entende, aqui, por materiais (outros materiais, além dos brinquedos. Ex: panelas, caixas, lápis, papel, cola, etc.).

Foram incluídos, neste questionário, alguns itens relacionados à escolarização, ao tratamento da criança e ao grau de escolaridade dos cuidadores. Também foram incluídos alguns subitens nas questões “Como a criança brinca com os brinquedos e os outros materiais?” e “Como a criança brinca com as pessoas?”, visando evidenciar os comportamentos considerados importantes e facilitar a análise das respostas. Para a questão “Quando a criança brinca?”, foi realizada uma esquematização dos horários, com o objetivo de facilitar a resposta dos cuidadores. O Histórico Lúdico adaptado, com as questões abertas e com as de múltipla escolha, encontra-se no APÊNDICE B.

Além deste, no decorrer da pesquisa foi desenvolvido um outro questionário para os cuidadores, dado a necessidade de se coletar algumas informações a respeito do histórico de cada criança. Este questionário, que pode ser encontrado no APÊNDICE C, inclui questões abertas a respeito do desenvolvimento da criança, dos tratamentos realizados, da sua participação nas atividades familiares e comunitárias, da constituição familiar e da rotina diária da criança.

As informações obtidas por meio de ambos os instrumentos foram utilizadas na caracterização de cada um dos participantes.

\subsubsection{Roteiro para análise das atividades lúdicas}

As brincadeiras realizadas no decorrer desta pesquisa foram analisadas por meio de um roteiro baseado nos critérios elaborados por Bomtempo (1990), quais sejam: 
$1^{0}$. Tipo de brinquedo: este critério diz respeito às características do brinquedo ou da brincadeira, incluindo a quantidade de peças, o tipo de material, o nível de estruturação ${ }^{39}$ da brincadeira, o tipo de regras envolvidas (implícitas ou explícitas, simples ou complexas), o grau de complexidade do brinquedo ${ }^{40}$ (que leva em conta, entre outros aspectos, o número de peças, a forma, a cor e o tamanho) e se é cooperativo ou competitivo.

$2^{\circ}$. Desenvolvimento e aprendizagem: enfatiza o que, de maneira geral, a criança pode aprender por meio do brinquedo ou brincadeira em questão, por exemplo, noções de matemática, lateralidade, discriminação visual ou espacial, coordenação motora, socialização, entre outros.

$3^{\circ}$. Usos do objeto: item no qual são incluídas as finalidades ou temas que o brinquedo sugere, bem como o modo de realizar a brincadeira.

Visto que as brincadeiras aqui selecionadas destinavam-se a favorecer o desenvolvimento de conceitos básicos por crianças com seqüelas de paralisia cerebral, foram incluídos itens referentes às possibilidades de exploração da criança (sugestões de adaptações do brinquedo ou da brincadeira, caso a criança apresente dificuldades na manipulação dos objetos), conceitos que podem ser trabalhados (conceitos que podem ser envolvidos na brincadeira, incluindo-se mesmo aqueles que não faziam parte da pesquisa atual) e possibilidades de variação (modificações que podem ser feitas na brincadeira, visando enriquecer as experiências das crianças).

As brincadeiras realizadas pelas crianças participantes, analisadas com base nestes critérios, estão descritas no APÊNDICE D.

\footnotetext{
39 Segundo Bomtempo (1990), o brinquedo estruturado é aquele que reflete a finalidade a que se destina (por exemplo, panelinha é para brincar de casinha, carro é para brincar de corrida), o brinquedo semi-estruturado permite que, além de brincar da maneira sugerida pelo objeto, a criança descubra outras formas de brincar com ele e o brinquedo não-estruturado permite a livre expressão da criança.

${ }^{40}$ Neste caso, também será considerada complexa a brincadeira que apresentar várias etapas e/ou regras complexas.
} 


\subsection{Procedimento}

No início da pesquisa, foram realizados contatos com os profissionais das instituições participantes, sendo-lhes expostos os objetivos e a população-alvo deste estudo. Estes profissionais realizaram uma pré-seleção das crianças que se enquadravam nos critérios estabelecidos. Em uma das instituições, também foram selecionadas crianças por meio das listas de espera, visto o pequeno número de crianças que preenchiam o perfil desejado.

Após esta pré-seleção, os responsáveis que autorizaram a participação das crianças assinaram o Termo de Consentimento Livre e Esclarecido (vide APÊNDICE A). As crianças préselecionadas foram, então, avaliadas por meio dos itens de instrução do Teste de Conceitos Básicos de Boehm adaptado, que apresentam questões relativas a objetos familiares à maioria das crianças, tais como: peças do vestuário, meios de transporte, frutas, objetos de mesa, móveis e animais. Como exemplo destas questões, entre os desenhos de uma colher, um copo e uma xícara, pede-se para a criança indicar o copo. Estes itens de instrução destinam-se a orientar a criança quanto à maneira adequada de responder às perguntas do teste propriamente dito, mas foram utilizadas, aqui, também com o objetivo de avaliar se a criança apresentava condições de responder de maneira satisfatória ao teste, ou seja, se ela conseguiria visualizar adequadamente os desenhos apresentados, se compreenderia as perguntas feitas pelo examinador e se apresentava alguma forma de comunicação que permitiria responder às questões, fosse por meio da fala, de gestos ou do olhar.

As crianças que responderam adequadamente aos itens de instrução (ou seja, que acertaram ao menos quatro dentre as seis questões), realizaram o teste de conceitos adaptado na íntegra. O formato das questões do teste era semelhante ao dos itens de instrução, tal como exemplificado anteriormente, ou seja, eram mostrados três desenhos e a criança era solicitada a 
indicar o desenho que se relacionava ao conceito de interesse do pesquisador. Por exemplo: mostrava-se à criança o desenho de uma mesa com três bolas em diferentes posições espaciais e pedia-se que ela indicasse a bola que estava “debaixo” da mesa. Neste exemplo, investigava-se o conhecimento do conceito “debaixo”, pertencente ao domínio conceitual de espaço.

Durante a aplicação do pré-teste, não era permitida a presença de cuidadores ou professores da criança, para que estes não interferissem nos resultados da pesquisa, devido à possibilidade de ensinarem à criança os conceitos mencionados durante o teste. Entretanto, era facultada a presença de outros profissionais da instituição. Do mesmo modo, as crianças não eram informadas quanto aos acertos ou aos erros, visto que o mesmo instrumento seria utilizado no pós-teste.

Após a seleção das crianças que participaram da pesquisa e após a realização do pré-teste, os seus cuidadores foram solicitados a responder aos questionários sobre as brincadeiras que as crianças realizavam e sobre o seu desenvolvimento. Estes dados foram utilizados para auxiliar na análise dos resultados da pesquisa, pois permitiram identificar a presença das brincadeiras no dia a dia da criança, bem como observar como ocorria a participação da criança nas vivências familiares.

As crianças selecionadas para a pesquisa e avaliadas passaram, a seguir, por atendimentos de Terapia Ocupacional, que ocorreram individualmente, em sessões semanais de 50 minutos à uma hora cada (variando de acordo com as condições de cada instituição), por quatro ou cinco meses, totalizando 16 atendimentos. Estes atendimentos foram centrados no uso de atividades lúdicas, possibilitando que a criança, apesar de sua limitação motora, conseguisse brincar da maneira mais autônoma possível. A pesquisadora brincava com a criança e possuía um papel de mediadora, enriquecendo a brincadeira, fornecendo suporte técnico caso a criança não conseguisse manusear os objetos ou necessitasse de auxílio para manter um posicionamento 
adequado e utilizando a linguagem verbal com o objetivo de estimular o desenvolvimento dos conceitos avaliados no pré-teste.

Durante estes atendimentos, era facultada a presença de um acompanhante, sendo que o mesmo era convidado a participar das brincadeiras, juntamente com a criança e a pesquisadora. Em uma das instituições, as sessões também contaram com a presença de uma estagiária ${ }^{41}$, que participava das brincadeiras e auxiliava a pesquisadora na organização da sala de atendimentos.

No decorrer desta pesquisa, foi realizada uma seleção de brincadeiras, desde jogos com regras a atividades de livre expressão, que podem envolver conceitos e que, com ou sem adaptações e/ou ajuda de outras pessoas, podem ser realizadas por crianças com alterações motoras. Algumas destas brincadeiras foram oferecidas às crianças participantes da pesquisa, sendo as atividades realizadas de acordo com o interesse de cada criança.

No início de cada sessão, a criança era solicitada a escolher, dentre algumas atividades sugeridas pela pesquisadora, qual desejava realizar, mantendo-se, assim, a natureza voluntária da brincadeira. Para tanto, a pesquisadora apresentava três ou quatro opções de brinquedos e explicava brevemente o seu funcionamento. A criança, então, mostrava a brincadeira escolhida, seja por meio da fala, de gestos ou do olhar. Além de serem oferecidos brinquedos diferentes, era sempre dada a opção de a criança repetir as brincadeiras que já haviam sido realizadas. Também foram realizadas outras atividades sugeridas pela própria criança, cabendo à pesquisadora incluir os conceitos estudados na dinâmica da brincadeira. Dentre todas as brincadeiras selecionadas pela pesquisadora, apenas as brincadeiras efetivamente realizadas pelas crianças foram analisadas por meio dos critérios mencionados anteriormente e estão descritas mais adiante (APÊNDICE D).

\footnotetext{
${ }^{41}$ Ao procurar a instituição de ensino para realizar a pesquisa com as crianças atendidas na clínica-escola, houve um interesse por parte da instituição quanto à participação de um aluno do curso de Terapia Ocupacional. Por este motivo, foi aberto um projeto de iniciação científica, oferecendo uma vaga que foi preenchida por meio de um processo seletivo realizado pela coordenadora do curso. A aluna selecionada participou de todos os atendimentos oferecidos às crianças e elaborou um relatório final sobre a experiência vivenciada com uma das crianças participantes da pesquisa.
} 
Após o período de intervenção, as crianças incluídas na pesquisa foram reavaliadas por meio do mesmo instrumento utilizado no pré-teste, incluindo-se os itens de instrução, que, nesta fase, visavam somente reorientar a criança quanto à forma de responder ao teste.

Foram feitos registros, no diário de campo, de todas as atividades desenvolvidas em cada atendimento, incluindo-se a dinâmica da brincadeira, a participação da criança e de seu acompanhante, as dificuldades encontradas pela pesquisadora e as reflexões tecidas ao longo do estudo. Após o término do período de intervenção, estes diários de campo foram lidos várias vezes, para que fossem progressivamente resumidos, mantendo-se apenas os fatos essenciais para a compreensão da evolução de cada criança. Estes dados foram correlacionados aos resultados dos testes e às informações coletadas por meio dos questionários. Cada caso foi analisado individualmente e, em seguida, todos os relatos foram lidos sequencialmente, para que fossem identificados aspectos semelhantes e distintos, o que permitiu a análise conjunta dos casos em questão. 


\section{CAPÍTULO 6}

\section{RESULTADOS}

\subsection{Estudo de casos}

As sete crianças que participaram desta pesquisa foram acompanhadas por um período de quatro meses, em encontros semanais de cerca de uma hora cada. A seguir, será feito um relato de como se deu a participação de cada criança no decorrer da pesquisa. Em cada estudo de caso, inicialmente, é feita uma apresentação da criança e são mencionados os principais dados coletados por meio dos questionários respondidos pelos cuidadores. Em seguida, são relatadas as brincadeiras realizadas pela criança e os conceitos envolvidos em cada tipo de brincadeira. Nestes relatos, os conceitos que foram mencionados durante os atendimentos encontram-se entre aspas (visando facilitar a leitura, estes foram colocados entre aspas apenas na primeira vez que aparecem no relato que narra um mesmo tipo de brincadeira). Na seqüência, são feitas observações a respeito da evolução da criança no decorrer destes atendimentos. Por fim, são apresentados os conceitos que foram utilizados na pesquisa, bem como os resultados dos testes de conceitos.

\subsubsection{N. o pescador}

N., sexo masculino, sete anos e cinco meses de idade, apresenta seqüelas de paralisia cerebral tetraparética espástica, com predomínio à esquerda, tendendo a utilizar apenas a mão direita durante as tarefas. Apresenta alterações na locomoção (arrasta-se com dificuldades quando 
em decúbito ventral, não anda nem engatinha), tem dificuldades para manter-se sentado sem apoio e para preensão de objetos. Comunica-se por alguns gestos e expressões faciais.

A mãe de N. relata ter apresentado depressão no início da gestação da criança, fazendo uso de medicamentos antidepressivos. A criança nasceu de parto cesariano, não sendo relatadas intercorrências durante o mesmo. A mãe descobriu que a criança apresentava seqüelas de paralisia cerebral quando esta se encontrava com oito meses de idade, o que foi, no início, bastante difícil de aceitar. Seu desenvolvimento foi muito lento. Atualmente a criança faz hidroterapia, equoterapia, fonoaudiologia, terapia ocupacional e fisioterapia, no Instituto Águas Cristalinas e na escola Arco-íris.

N. mora com a mãe, o pai e a irmã. A relação da criança com a família é bastante carinhosa; contudo, a família de N. não tem muito contato com os demais parentes. Segundo a mãe, a criança é tratada com um carinho especial, devido à deficiência. A criança acompanha sua mãe ao mercado e à igreja (onde oram por ele - sic). N. freqüenta a pré-escola de uma escola especial. A mãe cursou até a $6^{\mathrm{a}}$ série e o pai, até a $2^{\mathrm{a}}$ série do ensino fundamental. Sua irmã ainda estuda, cursando a $7^{\mathrm{a}}$ série.

A mãe relatou que $\mathrm{N}$. não tem se interessado pelos brinquedos, pois gosta muito de ver televisão, a ponto de parar qualquer atividade para assistir a ela. Ele não pára quieto com um mesmo brinquedo e não inventa novas maneiras de brincar, brincando sempre da mesma forma; contudo, brinca de maneira apropriada com cada tipo de brinquedo, ou seja, sabe como utilizar um carrinho, uma bola, etc. Sua mãe não soube relatar se a criança realiza brincadeiras simbólicas, pois esta não fala, o que dificulta a observação deste tipo de atividade. Porém, segundo relatos, N. brinca sozinho e ri, o que pode ser indício de atividades simbólicas. Além disso, sua brincadeira preferida é brincar de cantor de rock e tocar um violãozinho, o que também envolve simbolismo. N. também costuma brincar com carrinho, bonecos e bola. Costuma brincar 
sozinho, ou com sua irmã, ou, às vezes, com outras crianças. A mãe relata que, devido à rotina intensa, tem poucas oportunidades para brincar com a criança. Durante a semana, N. brinca apenas na escola, no período da tarde. Nos finais de semana, brinca um pouco de manhã e um pouco à noite. Ás vezes, é necessário insistir para que brinque, pois prefere ficar vendo televisão.

Desde o primeiro contato com a pesquisadora, N. se mostrou atento e participativo. Quis repetir algumas brincadeiras, demonstrando maior interesse por carimbos, massinha e pescaria. Também brincou uma única vez com os seguintes brinquedos: bichinhos para montar de massinha, bolinhas e carrinhos de corrida (foram utilizados os dedoches da Turma da Mônica nesta última brincadeira). Quando solicitado a ajudar a guardar os brinquedos que não havia escolhido, N. entregava os outros brinquedos (empurrando a caixa em direção à pesquisadora), deixando na mesa apenas o brinquedo escolhido, o que mostra que possuía clareza em sua escolha. A Tabela 6.1 mostra as brincadeiras oferecidas à criança, bem como as por ela escolhidas.

Tabela 6.1 - Sujeito N.: brincadeiras oferecidas e brincadeiras escolhidas.

\begin{tabular}{|l|c|c|}
\hline Brincadeiras & Oferecidas & Escolhidas \\
\hline Carimbos & 7 & 2 \\
\hline Vira Lata & 4 & - \\
\hline Super-pinão & 1 & - \\
\hline Carrinhos & 3 & - \\
\hline Bolinhas & 4 & 1 \\
\hline Massinha & 2 & 2 \\
\hline Tinta e pincel & 1 & - \\
\hline Carrinhos de corrida & 3 & 1 \\
\hline Bichinhos de massinha & 2 & 1 \\
\hline Dedoches & 2 & 1 \\
\hline Zoológico & 4 & - \\
\hline Pescaria & 3 & 3 \\
\hline
\end{tabular}

N. brincou com os carimbos em dois atendimentos. Mesmo com a utilização dos carimbos adaptados, com os cabos engrossados e aumentados, N. necessitava de ajuda para manuseá-los. A 
criança escolhia a figura que gostaria de carimbar e realizava parte do esforço, contudo necessitava de ajuda para agarrar o carimbo, molhá-lo na tinta e estender o cotovelo em direção à folha. Em um atendimento, N. preferiu carimbar peixes em um desenho do fundo do mar. Foi-lhe perguntado se iria carimbar “em cima”, “embaixo” ou no “meio” da folha, de um "lado” ou do outro. Também foram trabalhados os conceitos de "perto” (carimbar o tubarão perto do peixe que este iria comer), “mais” (carimbar mais tubarões) e “muitos” (sendo comentado que havia muitos tubarões naquele mar). Também eram contados quantos peixes e quantos tubarões havia. Para pintar, N. escolhia a canetinha, a pesquisadora nomeava a cor e o ajudava a estender o braço para alcançar a folha; então, N. realizava os movimentos para rabiscar as figuras carimbadas.

A criança também brincou duas vezes com a massinha. Nesta brincadeira, a criança era auxiliada a manusear os utensílios e a realizar as ações. Foram trabalhados os conceitos de “dentro" (retirar a massa de dentro do pote), “meio” e "metade” (cortar a massa ao meio e escolher a metade que usaria), “depois” (qual figura fazer depois), “centro” (colocar a forminha no centro da massa ou o peixe no centro do lago), “em volta” (colocar os bichos em volta do lago), "lado", "lado direito” e "lado esquerdo" (ao escolher em qual lado da mesa colocaria os bichos), "grande” (fazer uma bola grande com a massinha), “primeiro” e “depois” (indicando a seqüência das tarefas), “cada” (fazer uma casa para cada bicho) e "sem” (identificar o bicho sem casa). A criança quis fazer uma maçã, então a pesquisadora sugeriu dividi-la entre dois bichos, cortando-a ao meio e dando uma metade para cada bicho. A criança conseguia reconhecer as figuras representadas nas forminhas, indicando corretamente as solicitadas pela pesquisadora.

Ao brincar com as bolinhas coloridas (atividade escolhida por outra criança que participou de um dos atendimentos), N. escolhia adequadamente uma bola para si e outra para o colega, sabendo esperar sua vez. N. era solicitado a esticar o braço à “frente” para jogar a bola na caixa. As cores das bolas escolhidas eram nomeadas. Visando facilitar a atividade, foi colocada uma 
cunha na frente da criança, formando uma rampa, de modo que, ao soltar as bolas no alto da rampa, estas rolavam em direção à caixa que se encontrava no chão. Foram também trabalhados os conceitos de “depois” (ao indicar a vez de cada jogador brincar), "muitas” (sendo indicado que havia muitas bolas), "pequenas” e "grandes” (pois havia dois tamanhos de bolas) e "quase” (quando as bolas estavam quase acabando). N. foi solicitado a guardar as bolas pequenas enquanto a outra criança guardava as grandes. Ao contrário da outra criança, N. guardou corretamente, sabendo identificar as bolas pequenas dentre as grandes.

No início de um dos atendimentos, foi feita a brincadeira Caça ao Tesouro, na qual a criança deveria encontrar desenhos espalhados pela sala, seguindo pistas, até encontrar o ‘tesouro’ (saquinho com doces). N. se interessou bastante pela brincadeira. A pesquisadora mostrava o desenho e perguntava para ele onde ficavam, na sala de atendimentos, os objetos mostrados na figura. Foram trabalhados os conceitos de "atrás”, “entre”, “debaixo”, "lado direito”, “em cima”, “centro” e “dentro”.

A criança também brincou uma única vez com os bichinhos de massinha. Este brinquedo é constituído por figuras de cabeças, patas e rabos de animais; a criança deveria fazer o tronco de massinha e encaixar estas partes do corpo ao tronco. Foram trabalhados, nesta brincadeira, os conceitos de "lado" e "meio" (ao escolher em qual parte da mesa ficaria cada peça do jogo), “metade” (ao cortar a massa), “dura” e “mole” (a respeito do tipo de massa), “entre”, “lado”, "lado direito" e "lado esquerdo" (ao escolher onde colocar cada bicho). A criança identificava adequadamente as partes do corpo pertencentes a cada animal. A pesquisadora conversava com a criança sobre a cor de massinha apropriada para cada um. N. necessitou de auxílio para fazer a bola com a massa e para encaixar as partes do corpo à bola.

N. brincou com os carrinhos de corrida em um atendimento. A criança ajudou a colar as faixas de largada e de chegada, segurando o rolo de fita crepe. Também foi colocada uma fita 
“entre” os dois carros, para que um não passasse para o "lado" do outro. Alguns dedoches da Turma da Mônica foram colocados nos carros, para dirigi-los. No início, para puxar o carro, a criança puxava o barbante apenas com a mão direita, e a pesquisadora ia enrolando a linha no rolo. Depois ela percebeu que N. conseguiria trocar as mãos para puxar o barbante, então pedia para que ele soltasse uma mão para segurar o fio, mais adiante, com a outra mão. Nesta brincadeira, também foram trabalhados os conceitos de "dentro" (retirar os carros de dentro da embalagem), “primeiro”, “lado direito”, “lado esquerdo”, “à frente” e “atrás”. Também foram utilizados uma ponte, para que os carros passassem "por cima”, e um túnel, para que os carros passassem "por baixo".

A brincadeira pela qual a criança demonstrou maior interesse foi a pescaria com peixes imantados, pois realizou esta atividade nos três últimos atendimentos. Eram utilizadas bacias de três tamanhos diferentes. Em uma das bacias era colocada água; as demais bacias eram utilizadas para colocar os peixes pescados pela criança e pela pesquisadora. Visto que a criança deixava a varinha de pescar cair de sua mão, o que lhe causava grande frustração, a pesquisadora enrolou uma flanela ao redor da mão que segurava a varinha, colando o pano com fita crepe. Assim, N. conseguia brincar com maior independência, necessitando de ajuda apenas para retirar o peixe do anzol. Em alguns momentos, conseguia jogar o peixe pescado em sua bacia, sacudindo a varinha. Em apenas um momento, levou o peixe para o "lado" errado, colocando-o na bacia da pesquisadora. Após cada pescaria, a pesquisadora enfileirava os peixes, colocando-os lado a lado, e os contava. Nesta brincadeira, também eram trabalhados os conceitos de "pequeno", "tamanho médio”, "grande” (no que se refere aos tamanhos das bacias), “muitos”, “poucos”, “mais”, “menos” (quanto à quantidade de peixes pescados por cada participante), “vazia” (quando acabavam os peixes da bacia com água), “quase” (quando a criança quase conseguia acertar o 
anzol na boca do peixe) e "dentro" (ao voltarem os peixes para dentro da bacia). Aos poucos a criança passou a pescar com maior independência, necessitando de menor ajuda.

No decorrer das sessões, foi possível observar que $\mathrm{N}$. era bastante atento às tarefas propostas e às falas da pesquisadora, parecendo compreender tudo o que lhe era dito. Demonstrava correção em suas escolhas, apontando para o que desejava. Participava de todas as tarefas dentro de suas possibilidades motoras, direcionando o braço para o que desejava pegar, tentando permanecer com o objeto em sua mão (embora muitas vezes o objeto caísse) e realizando parte do movimento necessário para a ação. Respondia com a cabeça se desejava ou não algo. Aceitava bem a ajuda para realizar a atividade que não conseguia executar com independência. Quando a pesquisadora percebia que a criança conseguia realizar alguma parte da tarefa, diminuía o grau de assistência, o que possibilitava um aumento progressivo da participação da criança.

N. participava ativamente de todas as etapas da brincadeira, ajudando a guardar debaixo do tablado os brinquedos não escolhidos e a limpar e guardar os brinquedos utilizados em cada atendimento. Ele era sempre solicitado a escolher o que desejava, do início ao final dos atendimentos. Sua mãe também foi orientada a oferecer, sempre que possível, opções para que N. escolhesse o que desejava, estimulando o desenvolvimento de sua autonomia.

Devido às dificuldades em manipular os objetos, foram necessárias algumas adaptações, tais como engrossar os cabos dos brinquedos ou enrolar um pano em volta de sua mão para que não deixasse o objeto cair. Todas as modificações nas atividades eram feitas com o seu consentimento. Mesmo ao utilizar os objetos adaptados, necessitava de auxílio para algumas partes da tarefa, contudo parecia não se importar em ser ajudado.

No decorrer dos atendimentos, foram testados diferentes posicionamentos para a criança. O posicionamento que se mostrou mais adequado para sua participação nas brincadeiras foi 
permanecer em sua cadeira de rodas adaptada, de frente para a mesa. Pois, em sua própria cadeira, permanecia bem posicionado, de modo que os espasmos extensores, provocados pela ansiedade ao brincar, não fizessem com que escorregasse. Assim, N. parecia se sentir mais seguro e livre para brincar, pois não havia o risco de cair, e a pesquisadora tinha seus braços livres para auxiliá-lo em suas tarefas, sem a preocupação constante com o seu posicionamento.

Embora não fosse o objetivo principal das sessões, as brincadeiras também favoreceram o uso de ambas as mãos durante as tarefas, visto que, anteriormente, a criança costumava usar apenas a mão direita. Sua mãe também percebeu a importância do uso das órteses, ao observar que, ao utilizá-las, a criança apresentava uma melhora no desempenho durante as tarefas. Contudo, em algumas brincadeiras, o uso das órteses impedia que N. executasse as ações com independência, pois, manter o punho em extensão dificultava a abertura dos dedos ao tentar soltar os objetos ou ao tentar segurar objetos grandes. Nestes casos, a pesquisadora preferia retirar as órteses, não privilegiando o posicionamento adequado à custa da função independente da criança.

Sua mãe era sempre convidada a participar das brincadeiras, mas, na maioria das vezes, preferiu apenas observar. No início da pesquisa, relatou que seu filho estava sendo ‘perdido’ pela televisão, não se interessando pelos brinquedos, o que, segundo ela, estaria causando uma regressão de seu quadro. Ao final da pesquisa, mencionou que ele já não se interessava tanto pela televisão, mostrando-se mais interessado pelos brinquedos e permanecendo em uma mesma brincadeira por um tempo maior. Também relatou que aprendeu como brincar com seu filho, além de ter conhecido brincadeiras diferentes.

Por motivos de doença ou dificuldades com o transporte, N. faltou a seis dos 16 atendimentos oferecidos. Este fato interferiu no seguimento das atividades da pesquisa, visto que, por duas vezes, ele faltou em dois atendimentos seguidos, levando a um grande espaço de tempo entre uma sessão e outra. Além disso, visto que a primeira e a última sessões eram dedicadas ao 
pré-teste e ao pós-teste, os conceitos envolvidos na pesquisa foram trabalhados em apenas oito atendimentos. A Tabela 6.2 apresenta os conceitos avaliados por meio do Teste de Boehm ${ }^{42}$ que foram trabalhados no decorrer destes atendimentos.

Tabela 6.2 - Sujeito N.: número e porcentagem de sessões em que os conceitos foram trabalhados nas brincadeiras.

\begin{tabular}{|l|c|c|}
\hline Conceito & No. de sessões & \% de sessões \\
\hline Debaixo & 5 & 62,5 \\
\hline Depois & 4 & 50 \\
\hline Muitos & 3 & 37,5 \\
\hline Lado direito & 3 & 37,5 \\
\hline Centro & 3 & 37,5 \\
\hline Metade & 3 & 37,5 \\
\hline Quase & 2 & 25 \\
\hline Tamanho médio & 2 & 25 \\
\hline Menos & 2 & 25 \\
\hline Entre & 2 & 25 \\
\hline Em volta & 1 & 12,5 \\
\hline Cedo & - & - \\
\hline Nunca & - & - \\
\hline Logo & - & - \\
\hline Agora & - & - \\
\hline
\end{tabular}

Os conceitos mais trabalhados nas brincadeiras foram “debaixo” (utilizado em 62,5\% dos atendimentos) e “depois” (50\%), seguidos pelos conceitos de “muitos”, "lado direito”, “centro” e “metade” (com 37,5\% cada). Os conceitos de "quase”, "tamanho médio”, “menos” e "entre” foram trabalhados em apenas $25 \%$ das sessões, sendo o conceito de "em volta" o menos trabalhado (12,5\%). Alguns conceitos não estavam envolvidos em nenhuma brincadeira: “cedo”, “nunca”, “logo” e “agora”. Além dos conceitos avaliados por meio do Teste de Boehm, outros também foram trabalhados nas brincadeiras. Na Tabela 6.3 eles são arrolados.

\footnotetext{
${ }^{42} \mathrm{Na}$ apresentação dos resultados, sempre que nos referimos ao Teste de Boehm, estaremos nos referindo ao instrumento adaptado pela autora.
} 
Tabela 6.3 - Sujeito N.: conceitos trabalhados nas brincadeiras, mas não avaliados pelo Teste de Boehm $^{43}$.

\begin{tabular}{|l|c|c|}
\hline Conceito & No. de sessões & \% de sessões \\
\hline Lado & 8 & 80 \\
\hline Grande & 6 & 60 \\
\hline Dentro & 5 & 50 \\
\hline Meio & 4 & 40 \\
\hline Cores & 4 & 40 \\
\hline Pequeno & 4 & 40 \\
\hline Mais & 3 & 30 \\
\hline Em cima ou por cima & 3 & 30 \\
\hline Lado esquerdo & 3 & 30 \\
\hline Frente & 2 & 20 \\
\hline Cada & 2 & 20 \\
\hline Primeiro & 2 & 20 \\
\hline Atrás & 2 & 20 \\
\hline Perto & 1 & 10 \\
\hline Diferente & 1 & 10 \\
\hline Sem & 1 & 10 \\
\hline Por baixo & 1 & 10 \\
\hline Poucos & 1 & 10 \\
\hline Duro & 1 & 10 \\
\hline Mole & 1 & 10 \\
\hline Vazia & 1 & 10 \\
\hline
\end{tabular}

Dentre estes conceitos, o mais trabalhado foi o conceito de "lado" (utilizado em 80\% dos atendimentos), seguido pelos conceitos de "grande” (60\%) e “dentro” (50\%).

Em uma brincadeira, foi possível perceber que a criança dominava o conceito de “diferente”, visto que conseguiu pegar adequadamente um peixe diferente dos já carimbados. Por outro lado, não dominava o conceito de "sem”, pois não soube identificar, em outra brincadeira, qual bicho estava sem casa.

Devido às dificuldades apresentadas pela criança quanto à comunicação e devido ao pouco tempo destinado aos atendimentos, não foi possível observar, durante as brincadeiras, a

\footnotetext{
${ }^{43}$ Em alguns dos estudos de caso, o número total de sessões em que foram trabalhados os conceitos avaliados pelo Teste de Boehm não corresponde ao número de sessões nas quais foram trabalhados os demais conceitos. Isto ocorreu pelo fato de que os conceitos não avaliados puderam ser incluídos em brincadeiras realizadas antes da aplicação do pré-teste ou após a aplicação do pós-teste.
} 
compreensão da criança no que se refere aos conceitos selecionados para a pesquisa. Assim, não foi possível confrontar os resultados dos testes com o desempenho da criança no decorrer das atividades. A Tabela 6.4 mostra os resultados do pré-teste e do pós-teste.

Tabela 6.4 - Sujeito N.: resultados do pré e pós-teste, no Teste de Boehm ${ }^{44}$.

\begin{tabular}{|c|c|c|}
\hline Conceitos & Pré-teste & Pós-teste \\
\hline 1 - Inst. Sapato & A & $\mathrm{A}$ \\
\hline 2 - Inst. Banana & A & A \\
\hline 3 - Inst. Carro & A & A \\
\hline 4 - Inst. Mesa & A & A \\
\hline 5 - Inst. Copo & A & A \\
\hline 6 - Inst. Cachorro & A & A \\
\hline Total - instrução & 6 & 6 \\
\hline 1 - Depois & $E_{c}$ & A \\
\hline 2 - Centro & $\mathrm{E}$ & A? \\
\hline 3-Quase & A & A \\
\hline $4-$ Em volta & $E_{c}$ & $E_{c}$ \\
\hline 5 - Cedo & A? & $E_{a}$ \\
\hline 6 - Nunca & $\mathrm{E}_{\mathrm{ca}}$ & $E_{c}$ \\
\hline 7 - Metade & $E_{c}$ & $E_{c}$ \\
\hline 8 - Lado direito & A? & $E_{a}$ \\
\hline 9 - Tam. Médio & $E_{b}$ & $\mathrm{E}_{\mathrm{b}}$ \\
\hline 10 - Menos & $E_{b}$ & A \\
\hline 11 - Entre & A? & $E_{c}$ \\
\hline 12 - Logo & $E_{b}$ & $E_{C}$ \\
\hline 13-Debaixo & $E$ & A \\
\hline 14-Muitas & $E$ & $E_{a}$ \\
\hline 15-Agora & $\mathrm{A}$ & $\mathrm{A}$ \\
\hline Total-acertos & 5 & 6 \\
\hline
\end{tabular}

N. respondia ao teste apontando, com o dedo ou com a mão direita, para a questão que julgasse correta; quando ele apontava para mais de um item, a pesquisadora pedia para que se decidisse, então ele apontava para um item apenas. Tanto no pré-teste quanto no pós-teste, $\mathrm{N}$. acertou todas as questões de instrução, mostrando que compreendeu o modo de realização do

\footnotetext{
${ }^{44} \mathrm{~A}$ letra "A" indica acerto; a letra "E” indica erro. A letra subscrita à letra "E" indica a resposta incorreta dada pela criança.
} 
teste e que dominava os conceitos inicialmente avaliados (conceitos referentes a alguns objetos do dia a dia.).

No pré-teste ele acertou as questões referentes aos conceitos de “quase”, “cedo”, “entre”, “lado direito” e “agora”, mas, no pós-teste, destes itens, ele acertou apenas “quase” (que foi utilizado em dois atendimentos) e "agora” (não trabalhado durante os atendimentos). Este fato parece indicar que os demais acertos do pré-teste ocorreram por acaso, visto que os mesmos não se repetiram no pós-teste.

No pós-teste, N. acertou algumas questões que havia errado no pré-teste, sendo estas as questões referentes aos conceitos de “depois”, “menos”, “debaixo” e “centro”. Destes quatro conceitos, o conceito “debaixo” foi bastante trabalhado durante os atendimentos (em 62,5\% dos atendimentos), pois a pesquisadora pedia para que a criança a ajudasse a guardar os brinquedos debaixo do tablado (embora N. não conseguisse fazer a tarefa sozinho, ele a auxiliava, empurrando o objeto em sua direção, e prestava bastante atenção enquanto a pesquisadora terminava a tarefa). O conceito de "depois" foi o segundo mais trabalhado (50\%), seguido pelo conceito “centro" (37,5\%). O conceito “menos” (26\%), foi trabalhado nos dois últimos atendimentos, o que pode ter influenciado no resultado. Na questão referente ao conceito de “centro”, a criança apontou para a opção correta, contudo também indicou uma opção incorreta, sendo o resultado duvidoso.

Desde a realização do pré-teste, a pesquisadora havia considerado duvidoso o acerto da questão referente ao conceito de "lado direito", pois a criança estava usando a mão direita para apontar e, quando não sabia a resposta, mostrava com maior freqüência o desenho que estava no lado direito da cartela (até este item, em todas as respostas, corretas ou incorretas, foram apontados os desenhos que se encontravam no lado direito). A não dominância deste conceito foi comprovada no pós-teste, no qual a criança não acertou a questão referente a este conceito. 
O conceito de "lado", que não fazia parte da pesquisa, foi trabalhado em 8 atendimentos (80\%). Assim, embora tenha errado, no pós-teste, o conceito de "lado direito”, a criança indicou a opção A, que equivale ao lado esquerdo, mostrando que conhece o conceito de lado, ao contrário de outras crianças que indicam, para esta questão, a opção B, que se encontra no meio da cartela.

A criança errou, no pós-teste, as questões referentes a conceitos que foram pouco trabalhados nas brincadeiras, sendo estes os conceitos de “muitas” (37,5\%), “metade” (37,5\%), “lado direito” (37,5\%), “tamanho médio” (25\%), ”entre” (25\%) e “em volta” (12,5\%). Alguns conceitos, cujas questões foram respondidas de maneira incorreta pela criança, não foram trabalhados em nenhuma sessão: “cedo”, "nunca” e "logo”.

\subsection{2 - F. o libertador dos bichos}

F., sexo masculino, seis anos e 11 meses de idade, apresenta seqüelas de paralisia cerebral diparética espástica, locomovendo-se com auxílio de muletas canadenses e realizando mudanças posturais com dificuldades. Apresenta boa habilidade com ambos os membros superiores e se comunica sem dificuldades.

Segundo sua mãe, a gravidez de F. não foi planejada e ocorreram intercorrências. Seu parto foi prematuro, aos sete meses de gestação. Apenas quando a criança estava com 10 meses de idade, sua mãe descobriu que ela apresentava seqüelas de paralisia cerebral, tendo sido difícil compreender o que estava acontecendo com a criança. F. realizou, anteriormente, aplicação de toxina botulínica, fisioterapia e hidroterapia na AACD; também realizou fisioterapia e terapia ocupacional num centro de referencia municipal. Atualmente, realiza hidroterapia no Instituto Águas Cristalinas e iniciou, há pouco tempo, fisioterapia em uma unidade básica de saúde. 
F. mora com o pai, a mãe, uma irmã e um irmão, em uma casa de três cômodos, sendo dois quartos e um banheiro no andar de cima e uma cozinha e uma área no andar de baixo. A criança participa de todas as atividades e passeios familiares. F. é tratado como as demais crianças, contudo, segundo sua mãe, recebe um pouco mais de atenção, devido a sua deficiência. Freqüenta a pré-escola de uma escola comum e seus pais cursaram até a $8^{\mathrm{a}}$ série do ensino fundamental.

A criança gosta de brincar com bonequinhos de super-heróis, bola, carrinhos, jogo da memória, entre outros brinquedos. Brinca também com materiais, tais como paus, pedras, lápis, papel, cola e massinha. Apesar de gostar muito de animais, tem medo destes, não tendo animais de estimação. Segundo observações de sua mãe, a criança fica bastante tempo com um mesmo brinquedo, inventa novas formas de brincar com os objetos e usa a imaginação, inventando histórias e personagens. A sua brincadeira preferida é com bonecos de luta, contudo evita brincadeiras de correr, tais como pega-pega. Brinca sozinho, com os irmãos e outras crianças, mas brinca pouco com seus pais. A mãe observa que F. brinca por mais tempo se estiver com alguém do que se estiver brincando sozinho. A mãe lê histórias para os filhos. F. gosta de mandar nas brincadeiras, mas obedece às regras das mesmas. Durante a semana, de manhã, vê desenhos na televisão e, à noite, brinca por pouco tempo com seu irmão. Nos finais de semana, brinca praticamente o dia inteiro, com seus irmãos, primos e amiguinhos. Segundo sua mãe, se pudesse, F. brincaria sempre, o dia inteiro.

Desde o primeiro dia de atendimento, a criança interagiu muito bem com a pesquisadora, mostrando-se comunicativa e participativa em todas as tarefas. A pesquisadora oferecia três ou quatro opções de brincadeiras, mas, no início da pesquisa, F. demonstrava dúvidas no momento da escolha. Conforme ele foi compreendendo que poderia brincar com outros brinquedos em outros atendimentos, foi demonstrando menor ansiedade no momento da escolha, inclusive escolhendo com antecedência a brincadeira da semana seguinte. 
Após realizar uma brincadeira, a criança sempre dizia que aquela era a mais divertida e que brincaria com aquilo em todos os demais atendimentos, contudo, na sessão seguinte, acabava optando por fazer outra coisa. F. brincou com os carimbos e com o jogo da memória em três atendimentos cada um, demonstrando maior interesse por tais atividades. Brincou duas vezes com a cidade, incluindo os carrinhos e os dedoches da Turma da Mônica. Também brincou duas vezes com os bichinhos de massinha e o zoológico. Realizou uma única vez as seguintes brincadeiras: pintura e colagem, Vira Lata, varetas gigantes e pescaria. Os dedoches da Turma da Mônica e os carrinhos foram incluídos em outras brincadeiras. A Tabela 6.5 apresenta as brincadeiras oferecidas pela pesquisadora e escolhidas pela criança.

Tabela 6.5 - Sujeito F.: brincadeiras oferecidas e brincadeiras escolhidas.

\begin{tabular}{|l|c|c|}
\hline Brincadeiras & Oferecidas & Escolhidas \\
\hline Carrinhos & 3 & 2 \\
\hline Carimbos & 4 & 3 \\
\hline Vira Lata & 3 & 1 \\
\hline Varetas gigantes & 2 & 1 \\
\hline Corrida de carrinhos & 2 & - \\
\hline Jogo da memória & 3 & 3 \\
\hline Pintura e colagem & 1 & 1 \\
\hline Cidade & 4 & 2 \\
\hline Dominó de metades & 1 & - \\
\hline Massinha & 1 & - \\
\hline Bichinhos de massinha & 4 & 2 \\
\hline Zoológico & 4 & 2 \\
\hline Dedoches & 2 & 2 \\
\hline Macacão que gruda & 1 & - \\
\hline Equilibristas malucos & 1 & - \\
\hline Jogo de argolas & 1 & - \\
\hline Pescaria & 1 & 1 \\
\hline
\end{tabular}

Antes da pesquisadora e a criança brincarem com as varetas gigantes, compararam estas com as varetas de tamanho convencional, percebendo que umas eram "pequenas" e "finas", enquanto as outras eram "grandes” e "grossas”, o que mostrou que a criança já dominava estes conceitos. Combinaram usar apenas uma mão a cada rodada, iniciando-se o trabalho com a 
lateralidade, sem ainda nomear os lados. Contavam quantas varetas cada um havia conseguido pegar. A pesquisadora pareava vareta por vareta e, então, comparavam quem possuía “mais” e quem possuía “menos”. Também separaram as varetas por cor, visando comparar quem possuía mais e menos varetas de cada cor. Foi feita uma modificação na regra da brincadeira, estabelecendo que o jogador poderia mexer um pouquinho as demais varetas ao tentar pegar uma delas, visto que F. sempre mexia outras varetas devido à dificuldade em manter-se sentado sem o apoio dos membros superiores; contudo, esta regra valia para ambos, pesquisadora e criança.

Em três atendimentos intercalados, a criança brincou com o jogo da memória dos "Ursinhos e seus Amigos”, que consiste em encaixar ursinhos sobre pares de figuras de bichos e, em seguida, procurar por estes pares escondidos. Visto que, quando um jogador encontra um par de bichos, recolhe para si os ursinhos que os escondiam, combinavam que a criança colocaria seus ursos, por exemplo, no "lado esquerdo" e a pesquisadora, no "lado direito" da mesa. Contavam quantos ursos cada um possuía e comparavam quem tinha "mais" e quem tinha "menos”. Neste jogo, também eram trabalhados os conceitos de "par”, “lado”, “entre”, “perto”, “centro” (ao darem dicas para o parceiro de onde o par se encontrava no tabuleiro) e "frente" (ao decidirem a posição em que colocariam os ursos),

Em um atendimento, após brincarem com o jogo da memória, decidiram brincar com o jogo Vira Lata. As latas foram colocadas no chão, “lado” a lado. Visto que, ao derrubá-las, algumas latas caíam debaixo do armário, F. sugeriu colocar todas as latas do outro lado da sala. Também decidiram acrescentar cones à brincadeira e F. comentou que ficaria como um jogo de boliche. Combinaram de que lado ficariam as latas e de que lado ficariam os pinos e, ao jogarem, nomeavam de que lado queriam acertar. Contaram quem tinha "mais" ou “menos” pinos e latas.

F. brincou com os carimbos em três atendimentos, sendo dois atendimentos seguidos, nos quais desenvolveu uma atividade mais planejada. Assim, no primeiro dia que brincaram com os 
carimbos, decidiram carimbar bichos do mar em uma folha e bichos da terra, em outra. Selecionaram e separaram os carimbos dos dois tipos de bichos, colocando-os um em cada "lado" da mesa. Observaram que havia "mais" carimbos de bichos da terra e "menos" de bichos do mar. Enquanto carimbavam, nomeavam os bichos. Ele sugeriu colar os bichos na parede, contudo, a pesquisadora disse que não poderiam colar na parede, mas em cartolinas. Então combinaram de desenhar o mar em uma cartolina e a selva, em outra, para colarem as figuras carimbadas. $\mathrm{Na}$ semana seguinte, terminaram de carimbar os bichos, cortaram uma cartolina ao "meio" e colocaram uma metade do "lado direito" e outra do "lado esquerdo" da mesa. Recortaram as figuras carimbadas, colocando cada tipo de bicho em um cesto, estando cada cesto de um "lado" da mesa. Ele comentou que, como o mar é grande, os peixes ficariam no cesto "grande". Começaram a desenhar, e a pesquisadora lhe explicou que a areia fica "por baixo" do mar. Na outra semana, terminaram a atividade de pintura e colagem, desenhando, de um "lado" da folha, um cenário para os bichos da selva e, do outro lado, um cenário para os bichos da fazenda, pois, segundo ele, há bichos perigosos na selva. Começaram a colar os bichos nas cartolinas; a pesquisadora precisou mostrar-lhe que a cola deveria ser passada na parte de "trás” do papel. Ela colocou os peixes iguais próximos (visando facilitar a contagem) e comentou que os peixes iguais gostam de nadar juntos. Ela perguntou se o tubarão fica no fundo do mar ou lá “em cima”, e ele disse que ficam "embaixo”, só indo para cima quando pulam. Comentaram de que tipo de peixe havia "mais" e de que tipo havia "menos".

A criança brincou de montar uma cidade em dois atendimentos, utilizando os blocos de madeira com desenhos de casas e estabelecimentos. Foram utilizadas as cartolinas com os desenhos da selva e do mar, sendo que cada uma ficava de um "lado" da cidade. Nomeavam os blocos de madeira que possuíam figuras de estabelecimentos comerciais; quando a criança não identificava, a pesquisadora lhe dava dicas. Combinaram que os blocos "compridos”, sem 
desenhos, seriam os prédios. A criança escolheu colocar o túnel de papelão "longe” e a ponte, “perto”. Escolhiam se cada bloco ficaria no "lado direito” ou no "lado esquerdo”. Comentavam se um estabelecimento estava "perto" de outro, ou "entre” dois outros. Ele comentou que quem fosse ao hospital, por exemplo, poderia ir de ônibus, pois o terminal estava perto, mostrando dominar este conceito. Comentavam sobre o lado que tinha "mais" ou "menos" coisas e sobre o tamanho de cada prédio, “pequeno”, “médio” ou “grande”. Falavam sobre a vida na cidade e nos prédios. Espalharam alguns carros pela cidade; a pesquisadora amarrou alguns carros no barbante e fizeram uma corrida, puxando-os pelos fios. Na semana seguinte, F. quis repetir a brincadeira, mas solicitou que colocassem pessoas na cidade. A pesquisadora, então, pegou alguns bonequinhos de pano e os dedoches da Turma da Mônica. Ele comentou que, com as pessoas, a cidade era mais legal, pois era uma cidade viva. Também colocaram os bonecos da Turma da Mônica para serem os motoristas dos carros.

No início de um atendimento, fizeram a brincadeira da Caça ao Tesouro, a qual envolve os seguintes conceitos: “entre”, “debaixo”, “atrás”, “lado direito”, “em cima”, “centro” e “dentro”. A criança participou ativamente e ficou bastante entusiasmada em seguir as pistas para encontrar o ‘tesouro’ (saquinho com doces).

F. brincou, em um atendimento, com os bichinhos de massinha, utilizando o cenário do zoológico para espalhar os bichos “em cima”. Ele escolheu colocar as patas no "lado esquerdo”, os rabos no "lado direito" e as cabeças no "meio” da mesa, visando não misturá-los. Discutiam sempre se o tamanho do corpo estava adequado para aquele bicho ou se deveriam fazer um corpo “maior" ou "menor”. Também conversavam sobre a cor mais adequada para cada bicho, misturando massas de duas cores, quando necessário. Quando ele colocava a pata ou a cabeça no lugar errado, a pesquisadora dizia se deveria colocar de um "lado” ou de outro, na "frente” ou “atrás”. Depois que ele fazia o bicho, decidiam se aquele bicho ficaria de um lado, de outro, ou 
no “centro" do zoológico. Ele comentou sobre o bicho que julgava ser o mais bonito. Contaram quantas patas cada bicho possuía para identificarem qual possuía “mais” e qual possuía "menos” patas.

A criança brincou duas vezes com o zoológico. Colocaram os bichos em um cesto, de um "lado" da mesa e as demais peças, em outro cesto, do outro lado. Ele comentou que deveriam colocar pessoas para visitar o zoológico, então, utilizaram os dedoches. Abriram o tabuleiro com o desenho do zoológico e foram decidindo qual bicho ficaria de que "lado", sendo, às vezes, nomeado pela pesquisadora se haviam escolhido o "lado direito" ou o "lado esquerdo". Colocaram as cercas dos animais, decidindo quais precisavam de cercas "maiores". Ele comentou que este seria um zoológico ‘de respeito’, onde ninguém poderia pular a cerca dos animais e nem maltratar os bichos. Fizeram uma fila com os personagens, no lado de fora do zoológico e ele sugeriu que as pessoas usariam carros para entrarem no zoológico. Enquanto tratavam dos animais, decidiram a que horas o parque seria aberto. Observaram de que lado tinha “mais” e “menos” bichos, “muitos” e "poucos”. Abriram o zoológico e espalharam os dedoches pelo parque. F. comentou que poderiam colocar os personagens em duplas. Por fim, ele disse que os bichos poderiam voltar para a selva, então, pegaram o desenho da selva, confeccionado em outro atendimento, e colocaram os bichos perto. Ele disse que agora os bichos estavam em liberdade, assim como os escravos (uma novela sobre escravos havia terminado há poucos dias). Da segunda vez que brincaram, acrescentaram os bichos feitos de massinha. Ele disse que a abelha deveria ficar "longe” dos outros bichos, então colocaram três árvores cercando-a. Contaram qual bicho possuía mais e menos patas.

Em um atendimento, F. escolheu brincar com a pescaria, colocando água na bacia "grande”. A pesquisadora pegou outras duas bacias e ele escolheu de que "lado" ele colocaria os peixes que pescasse. Em algumas rodadas, combinaram que ganharia quem pescasse “mais”, em outra, quem 
pescasse "menos”, mas ele teve dificuldades em entender que, nestes momentos, deveria pescar menos peixes. Ao final de cada rodada, contavam os peixes para ver quem havia ganhado ou perdido.

No último atendimento, a criança repetiu a brincadeira com os carimbos, mas preferiu carimbar aleatoriamente pela folha. Neste dia, foram trabalhados os conceitos de "lado" (ao separarem os carimbos, ao carimbarem nos lados da folha e ao separarem os carimbos já utilizados), “inteira” e “metade” (ao escolherem o tamanho da folha), “vazio” (ao identificarem os espaços do papel sem figuras), "menos" e "muitos" (ao salientarem a quantidade de peixes carimbados).

F. aguardava ansiosamente pelo início de cada sessão. Envolvia-se bastante nas atividades, participando ativamente de todas as etapas das brincadeiras. Ao sair da sala, relatava sempre a sua mãe o que havia feito naquele dia. Após o último dia da pesquisa, a criança afirmou que havia gostado muito dos atendimentos, pois havia aprendido muitas brincadeiras que não conhecia.

Durante os atendimentos, F. aceitou, em muitos momentos, as sugestões da pesquisadora, engajando-se nas situações imaginárias. Contudo, também se mostrou bastante criativo, sugerindo modificações nas brincadeiras. A pesquisadora, então, adequava a sugestão da criança à situação, como pôde ser observado em um atendimento, no qual a criança sugeriu que colassem as figuras carimbadas na parede. A pesquisadora disse que não poderiam colá-las na parede, mas em folhas de cartolina. Esta idéia da criança foi desenvolvida pela pesquisadora, o que deu início a uma nova brincadeira, qual seja, a colagem das figuras de bichos num cenário de selva e as de peixes em um cenário de oceano.

F. demonstrou dificuldades em lidar com alguns conceitos de tempo. Por exemplo, em muitos atendimentos comentou que "amanhã” iria brincar com dado brinquedo. Nestas ocasiões, 
a pesquisadora explicava que não seria amanhã, mas na "semana que vem”. Após vários atendimentos, F. já acertava ou se corrigia quando dizia erroneamente que o atendimento seguinte seria “amanhã", demonstrando compreender melhor a diferença entre estes conceitos.

F. compareceu a 15 dos 16 atendimentos oferecidos. Sua mãe relatou que a criança aguardava com ansiedade pelo dia da terapia. Visto que o primeiro e o último atendimentos eram dedicados aos testes, os conceitos da pesquisa foram trabalhados em 13 sessões de brincadeiras. A Tabela 6.6 mostra o número de sessões nas quais estes conceitos foram utilizados.

Tabela 6.6 - Sujeito F.: número e porcentagem de sessões em que os conceitos foram trabalhados nas brincadeiras.

\begin{tabular}{|l|c|c|}
\hline Conceito & No. de sessões & \% de sessões \\
\hline Lado direito & 12 & 92,3 \\
\hline Menos & 10 & 76,9 \\
\hline Debaixo & 4 & 30,8 \\
\hline Centro & 3 & 23,1 \\
\hline Entre & 3 & 23,1 \\
\hline Tamanho médio & 2 & 15,4 \\
\hline Muitos & 1 & 7,7 \\
\hline Agora & - & - \\
\hline Depois & - & - \\
\hline Quase & - & - \\
\hline Em volta & - & - \\
\hline Cedo & - & - \\
\hline Nunca & - & - \\
\hline Metade & - & - \\
\hline Logo & - & - \\
\hline
\end{tabular}

Como é possível observar na Tabela 6.6, os conceitos que foram trabalhados em um maior número de atendimentos foram os conceitos de "lado direito" (92,3\%) e “menos" (76,9\%). Embora a criança não tenha errado outros conceitos no pré-teste, como apresentado mais adiante (na Tabela 6.8), alguns destes conceitos também foram incluídos nas brincadeiras, devido às situações encontradas nas mesmas. 
Além destes, outros conceitos não avaliados por meio dos testes também foram utilizados nas brincadeiras, os quais são apresentados na Tabela 6.7.

Tabela 6.7 - Sujeito F.: conceitos trabalhados nas brincadeiras, mas não avaliados pelo Teste de Boehm.

\begin{tabular}{|l|c|c|}
\hline Conceito & No. de sessões & \% de sessões \\
\hline Lado & 12 & 85,7 \\
\hline Lado esquerdo & 12 & 85,7 \\
\hline Mais & 10 & 71,4 \\
\hline Em cima ou para cima & 5 & 35,7 \\
\hline Atrás & 4 & 28,6 \\
\hline Grande & 4 & 28,6 \\
\hline Pequeno & 4 & 28,6 \\
\hline Meio & 3 & 21,4 \\
\hline Longe & 3 & 21,4 \\
\hline Perto & 3 & 21,4 \\
\hline Par & 2 & 14,3 \\
\hline Frente & 2 & 14,3 \\
\hline Dentro & 1 & 7,1 \\
\hline Fora & 1 & 7,1 \\
\hline Poucos & 1 & 7,1 \\
\hline Maior & 1 & 7,1 \\
\hline Menor & 1 & 7,1 \\
\hline Inteiro & 1 & 7,1 \\
\hline Comprido & 1 & 7,1 \\
\hline Fino & 1 & 7,1 \\
\hline Grosso & 1 & 7,1 \\
\hline Vazio & 1 & 7,1 \\
\hline
\end{tabular}

Dentre estes conceitos, os que foram trabalhados em um maior número de sessões foram os conceitos de "lado" e de "lado esquerdo" (85,7\%), seguidos pelo conceito de "mais" (71,4\%), visto que os primeiros eram relacionados ao conceito de "lado direito", enquanto este último era tomado em oposição ao conceito de "menos", os quais foram avaliados por meio do teste de conceitos.

No decorrer das brincadeiras, foi possível perceber que a criança dominava os conceitos de “pequeno”, “grande”, “fino”, “grosso”, “embaixo”, “em cima”, “perto” e “dupla”. 
Nos primeiros atendimentos, visando iniciar os trabalhos com a lateralidade ${ }^{45}$, a pesquisadora falava apenas a palavra lado, sem nomeá-los. Alguns exemplos de situações nas quais isto acontecia são as seguintes: deveriam pegar os objetos apenas com uma ou com a outra mão; deveriam guardar os objetos de um lado com a mão do mesmo lado; deveriam escolher o lado no qual um objeto seria colocado, etc. Quando a pesquisadora estava de frente para F., ela utilizava a mão do mesmo lado que ele (ou seja, se ele usasse a mão esquerda, ela usava a mão direita, sem nomear os lados), visando não confundi-lo. Em alguns momentos das brincadeiras, a pesquisadora nomeava se a criança havia escolhido o lado direito ou o lado esquerdo. Com o passar dos atendimentos, a criança precisava de ajuda para nomear um lado, mas, após identificar este, já conseguia nomear o outro lado. No final da pesquisa, foi possível observar que a criança apresentava a lateralidade um pouco mais estabelecida, tendo maior consciência do que significavam as palavras "lado direito" e "lado esquerdo”, mas ainda apresentava dificuldades, em situações práticas, para identificá-los com precisão.

No início da pesquisa, conforme avaliado pelo pré-teste, a criança não dominava o conceito de “menos”, precisando contar os objetos mesmo quando a diferença entre os grupos era notável (por exemplo, quando um grupo possuía dois e o outro dez objetos) ou quando os objetos eram pareados um a um. Apesar de sua mãe ter dito que a criança era boa com números (sic), foi possível observar, durante as brincadeiras, que a criança não dominava alguns conceitos referentes à quantidade. Parecia não compreender que cada número corresponde a uma quantidade específica de objetos. Assim, ao contar, pulava alguns itens ou contava duas vezes o mesmo. Em um atendimento, a criança fez uma continha de cabeça $(2+2=4)$, mas, logo em

\footnotetext{
${ }^{45}$ Segundo Le Boulch (1983), o trabalho com a lateralidade deve ser iniciado pela manipulação livre de objetos, utilizando-se ambos os lados do corpo, sem que os mesmos sejam nomeados, para que o modo de simbolizar não interfira na experiência da criança. Após esta etapa, a criança pode realizar as mesmas atividades, sendo nomeados os lados direito e esquerdo. A transferência para outrem (ou seja, a identificação do lado direito e esquerdo de outra pessoa ou objeto) é o último passo na aquisição de noções de lateralidade.
} 
seguida, ao contar alguns objetos, não contava de um por um (pulando ou contando duas vezes o mesmo). Este fato pode indicar que a criança conhecia conceitos matemáticos, sem saber aplicálos em situações concretas e espontâneas. A pesquisadora sempre o ajudava a contar, afastando os itens já contados, para que não se confundisse; em alguns momentos a própria criança solicitou ajuda para contar.

Com o decorrer dos atendimentos, além de aprender a contar os objetos um por um, F. passou a identificar com maior facilidade o grupo que possuía mais e o grupo que possuía menos objetos, mas apenas quando a diferença entre eles era facilmente observável e quando a comparação envolvia apenas dois grupos. A criança ainda apresentava dificuldades para contar um número grande de objetos (acima de 20). Entre mais de dois grupos de objetos, a criança passou a identificar facilmente o grupo com mais objetos, mas ainda precisava de ajuda para identificar o grupo com menos itens, pois apontava um grupo com número intermediário, mas não o grupo com o menor número de objetos. Quando a pesquisadora lhe mostrava os grupos com mais e com menos objetos em uma rodada da brincadeira, na rodada seguinte, a criança já conseguia acertar. Deste modo, é possível afirmar que houve uma evolução no aprendizado do conceito em tela, no decorrer das sessões, contudo, o conceito ainda não era aplicado em todas as situações. Assim, ao final da pesquisa, a criança conseguia contar com maior facilidade e conseguia identificar, dentre dois grupos de objetos, qual possuía mais e menos objetos, mesmo quando a pergunta se iniciava pelo conceito de “menos” e não pelo de “mais”. Quando a comparação envolvia mais de dois grupos, a criança ainda encontrava dificuldades.

A Tabela 6.8 mostra os resultados da criança, tanto no pré-teste, quanto no pós-teste. A criança acertou, no pré-teste, todos os conceitos referentes aos objetos do dia a dia e errou apenas a questão referente ao conceito de “menos”. 
Tabela 6.8 - Sujeito F.: resultados do pré e pós-teste, no Teste de Boehm.

\begin{tabular}{|c|c|c|}
\hline Conceitos & Pré-teste & Pós-teste \\
\hline 1 - Inst. Sapato & $\mathrm{A}$ & $\mathrm{A}$ \\
\hline 2 - Inst. Banana & $\mathrm{A}$ & $\mathrm{A}$ \\
\hline 3 - Inst. Carro & A & A \\
\hline 4 - Inst. Mesa & $\mathrm{A}$ & $\mathrm{A}$ \\
\hline 5 - Inst. Copo & A & $\mathrm{A}$ \\
\hline 6 - Inst. Cachorro & A & $\mathrm{A}$ \\
\hline Total - instrução & 6 & 6 \\
\hline 1 - Depois & $\mathrm{A}$ & $\mathrm{A}$ \\
\hline 2 - Centro & A & $\mathrm{A}$ \\
\hline 3-Quase & A & A \\
\hline 4 - Em volta & A & A \\
\hline $5-$ Cedo & A & $\mathrm{A}$ \\
\hline 6-Nunca & A & $\mathrm{A}$ \\
\hline 7 - Metade & $\mathrm{A}$ & $\mathrm{A}$ \\
\hline 8 - Lado direito & A? & A? \\
\hline 9 - Tam. Médio & A & A \\
\hline $10-$ Menos & $E_{a}$ & A? \\
\hline 11 - Entre & A & A \\
\hline $12-$ Logo & $\mathrm{A}$ & $\mathrm{A}$ \\
\hline 13 - Debaixo & $\mathrm{A}$ & $\mathrm{A}$ \\
\hline 14-Muitas & A & A \\
\hline 15 - Agora & A & A \\
\hline Total - acertos & 14 & 15 \\
\hline
\end{tabular}

Após a realização do pré-teste, a mãe de F. se queixou de que a criança, apesar de ser muito boa com números, apresenta dificuldades com as letras. Sabe-se que este tipo de troca de letras, como, por exemplo, a troca de “d” por "b” ou de “p” por “q”, é comum em crianças que ainda não têm a lateralidade bem estabelecida. Levando este aspecto em consideração, a pesquisadora fez perguntas a F. referentes às suas mãos direita e esquerda e a criança errou em duas tentativas. A pesquisadora mostrou-lhe novamente a figura do teste referente ao conceito de "lado direito" e lhe fez novamente a questão. F. errou, apesar de ter acertado esta questão durante a realização do pré-teste, o que sugere que o conceito não era dominado pela criança. Por este motivo, a pesquisadora optou por também realizar, com a criança, atividades que envolvessem a 
lateralidade. No decorrer destas atividades, conforme mencionado anteriormente, F. pareceu mostrar um pouco mais de noção em relação à lateralidade, compreendendo que há dois lados distintos e conhecendo o nome de ambos, ainda que não dominasse completamente estes conceitos. Assim, embora F. tenha acertado o conceito de “lado direito”, tanto no pré-teste quanto no pós-teste, estes acertos não podem ser considerados como indicativos da dominância do conceito em situações concretas, mas apenas que o conceito estava em fase de aprendizado.

No pós-teste, na questão referente ao conceito de “menos”, F. pareceu nem olhar para as demais opções e já apontou para o prato que tinha 3 doces. A pesquisadora perguntou se ele havia olhado para todos os pratos, então ele disse que estava em dúvida entre os dois (o que tinha três e o que tinha um doce - portanto tinha claro que o outro prato possuía mais). Então, a pesquisadora fez a pergunta novamente: “De todos os pratos, qual tem menos doces?”; ele apontou para o prato correto. Este acerto foi considerado duvidoso, pois talvez a pesquisadora tenha influenciado a criança ao ter perguntado novamente. Contudo, a criança não cogitou a possibilidade de que fosse o outro prato (com mais doces), o que mostra que F. sabia que um prato possuía mais doces e que os outros possuíam menos que este, parecendo dominar parcialmente o conceito. Nas brincadeiras, ele já acertava qual grupo de objetos possuía mais ou menos itens, parecendo ter aprendido a utilizar estes conceitos em algumas situações, mas não em todas. O que pôde ser observado é que, no início da pesquisa, F. tinha bastante dificuldade no que se refere à quantidade, não sabendo nem mesmo contar os objetos de maneira adequada. Ao longo dos atendimentos, F. foi adquirindo maior noção de quantidade, já sabendo, no final da pesquisa, comparar as quantidades entre dois grupos de objetos, mas não entre três grupos, como é o caso do teste de conceitos. Além disso, nas brincadeiras, os conceitos de mais e de menos costumavam ser trabalhados em oposição. De modo distinto, no teste, o conceito de menos é tomado isoladamente. 


\subsection{3 - B. a lançadora de bolas}

B., sexo feminino, com sete anos e cinco meses de idade, apresenta seqüelas de paralisia cerebral tetraparética espástica. A criança apresenta dificuldades para a marcha, mesmo com auxílio de terceiros, mas se arrasta em decúbito ventral. Senta-se com apoio e consegue manipular objetos grandes e pequenos satisfatoriamente, usando preferencialmente a mão esquerda. Apresenta um pouco mais de dificuldades no uso da mão direita, evitando, por isso, o uso desta. A criança não é muito comunicativa. Embora se utilize da fala apenas ocasionalmente, consegue estabelecer, nestes momentos, uma comunicação efetiva, expressando seus desejos ou respondendo a perguntas simples. Entretanto, em algumas ocasiões, nem mesmo sua mãe consegue compreender o que diz, pois a criança apresenta ecolalia ou fala palavras aparentemente sem sentido.

A gestação de B. não foi planejada e teve muitas intercorrências. Foi uma gestação de alto risco, sendo o parto prematuro no sétimo mês. O descobrimento da deficiência da filha foi uma situação muito difícil para a mãe, o que ocorreu quando a criança estava com oito meses de vida. Seu desenvolvimento foi muito lento. Fez tratamentos em fisioterapia, fonoaudiologia e terapia ocupacional, no DMR-HC; atualmente, realiza apenas hidroterapia.

A mãe de B. cursou até a $5^{a}$ série do ensino fundamental e B. freqüenta a primeira série de uma escola comum. A criança mora com a mãe e mais quatro irmãos, em São Paulo. A família se mudou para a cidade em busca de tratamento para a menina. Os demais parentes moram em Vitória (ES), para onde a mãe pretende voltar após uma cirurgia que B. aguarda há alguns anos. A mãe não relata contatos da criança com o pai. Segundo a mãe, a criança é tratada como os demais irmãos e se relaciona bem com os parentes, participando das festinhas familiares. A criança também acompanha a mãe à igreja e aos passeios. 
B. gosta de brincar de boneca, de brinquedos de montar, de bola, palhacinho, fogãozinho e panelinha. Também brinca com caderno, tesoura, cola, massinha e caixas. Tem um coelho e um gato. De acordo com observações feitas pela mãe, a criança fica bastante tempo com um mesmo brinquedo, inventando formas novas de utilizar os objetos e usando a imaginação. A mãe acredita que a criança brinca da maneira esperada com cada tipo de brinquedo. Sua brincadeira preferida é cantar e bater palmas.

A criança brinca sozinha, ou com os irmãos menores, ou com outras crianças; às vezes, brinca com a mãe. Ela gosta de mandar nas brincadeiras, mas também, segundo a mãe, obedece às regras. Durante a semana, a criança brinca sozinha ou com a mãe, à tarde, quando chega da escola e, à noite, brinca com a irmã. Nos finais de semana, brinca o dia inteiro com os irmãos ou com os primos. De acordo com a mãe, o dia a dia da criança é tranqüilo. B. faz atividades na escola e em casa, com os irmãos.

Desde o primeiro atendimento, foi possível perceber que a criança apresenta dificuldades em manter a atenção em uma mesma atividade. Ela parecia preferir atividades mais dinâmicas e repetitivas, visto que, nas brincadeiras que envolviam uma maior elaboração simbólica ou que exigiam o engajamento em uma tarefa com início, meio e fim, a criança logo se mostrava desmotivada, sendo necessário que a pesquisadora interferisse em todo o processo, visando mantê-la atenta à brincadeira. Deste modo, escolheu brincar, na maioria das vezes, com brincadeiras que envolvessem bolas e alvos, tais como: bolas e rolos, Vira Lata, bolas coloridas e bolinhas de pingue-pongue.

Intercaladas a estas brincadeiras, a criança também escolheu brincar duas vezes com os carimbos e uma única vez com os seguintes brinquedos: carrinhos, massinha, bichos de massinha, Monte Castelo e Zoológico. A pesquisadora ofereceu uma única vez a brincadeira com boneca, visto que sua mãe relatou ser esta a brincadeira mais freqüente da criança, quando está em casa. 
A Tabela 6.9 mostra as brincadeiras escolhidas por esta criança, bem como as brincadeiras que lhe foram oferecidas.

Tabela 6.9 - Sujeito B.: brincadeiras oferecidas e brincadeiras escolhidas.

\begin{tabular}{|l|c|c|}
\hline Brincadeiras & Oferecidas & Escolhidas \\
\hline Fantoches & 1 & - \\
\hline Vira Lata & 4 & 3 \\
\hline Super-pinão & 4 & - \\
\hline Bola e rolos & 1 & 1 \\
\hline Boneca (bebê) & 1 & 1 \\
\hline Carrinhos & 3 & 1 \\
\hline Dedoches & 3 & 2 \\
\hline Bolas coloridas & 8 & 4 \\
\hline Jogo da memória & 1 & - \\
\hline Pescaria & 3 & - \\
\hline Carimbos & 8 & 2 \\
\hline Massinha & 4 & 1 \\
\hline Tinta e pincel & 3 & - \\
\hline Bolinhas de pingue-pongue & 2 & 2 \\
\hline Ponte e rolos para derrubar & 1 & 1 \\
\hline Bichos de massinha & 5 & 1 \\
\hline Monte castelo & 2 & 1 \\
\hline Zoológico & 5 & 1 \\
\hline Carrinhos de corrida & 1 & - \\
\hline Macacão que gruda & 1 & - \\
\hline
\end{tabular}

Conforme sua mãe havia relatado sobre seu interesse por bonecos, logo no primeiro atendimento a criança escolheu brincar com o boneco de um bebê. Brincaram de dar banho e de alimentar o boneco, e a pesquisadora conversava com a criança sobre as etapas que aconteceriam “antes” e “depois”. Quando solicitada, a criança participava ativamente da brincadeira, como, por exemplo, quando fingiu lavar e enxaguar a cabeça da boneca. A criança soube indicar várias partes do corpo da boneca, quando questionada.

B. brincou com o jogo Vira Lata em três atendimentos. A pesquisadora comentava quando era preciso jogar mais “forte” ou mais “fraco” e indicava quando a bola caía “atrás” da mesa. Empilhou algumas latas e disse que era uma pilha "grande". Depois, em outros atendimentos, a 
própria criança já tentava empilhar as latas, então a pesquisadora comentava que a criança colocava uma lata "em cima" da outra, fazendo uma torre grande ou "alta”. A pesquisadora a ajudava e alertava quando as latas estavam caindo, para que se preparasse e levasse menos susto, pois se assustava com barulhos inesperados. A criança passou a brincar de soprar a torre de latas para que estas caíssem. A esta brincadeira, também eram acrescentadas bolas “grandes” e “pequenas”, com a criança escolhendo qual gostaria de utilizar. Além das latas, também eram utilizados rolos de papelão, para que a criança os derrubasse. A criança dava risadas quando acertava os alvos. A pesquisadora comentava quando a bola caía "longe”, “perto” ou "debaixo” da mesa.

Quando B. escolhia brincar com um tipo de bolinhas (por exemplo, as bolinhas coloridas), a pesquisadora acrescentava à brincadeira bolinhas de outro tipo (como as bolinhas de pinguepongue), para que fosse possível comparar as bolas "grandes” e as "pequenas”. Também eram utilizados dois tamanhos de cesto ou três tamanhos de bacias, para que fosse incluído o conceito de "tamanho médio". A criança brincava de retirar as bolas de um cesto e colocá-las no outro; nestes casos, a pesquisadora comentava que retirava de um "lado" e colocava do outro. Em outros momentos, a criança brincava de acertar as bolas nos cestos, sendo nomeado pela pesquisadora o tamanho do cesto acertado. B. também se divertia quando a pesquisadora colocava a cunha inclinada, com os cestos deitados na frente da cunha, de modo que ela soltava a bola no alto da cunha, para que esta rolasse até os cestos. A pesquisadora comentava quando a criança acertava “dentro” ou “fora” do cesto, quando havia “mais”, “muitas” ou “poucas” bolinhas em um local ou quando o cesto estava “cheio”, "vazio” ou “quase vazio”. Em um atendimento, foram utilizados dois rolos de papelão; a criança jogava a bolinha pelo buraco, para acertar o cesto, que estava à “frente”. A pesquisadora trocava os rolos de lugar e, então, perguntava se a criança colocaria a bolinha no rolo que estava de um "lado” ou do outro, “em cima” ou "embaixo”. No momento de 
guardar, a pesquisadora pedia para que guardasse as bolas pequenas em uma caixa e as grandes em outra. No início, ela confundia, colocando a bola no lugar errado, mas, com o passar dos atendimentos, começou a separar as bolas corretamente.

No primeiro dia em que B. brincou com os carimbos, foi necessário que a pesquisadora lhe mostrasse que, “primeiro”, precisavam molhar o carimbo na tinta para, “depois”, carimbar o papel. A pesquisadora a ajudava e ia perguntando se ela queria carimbar “mais”. Também sugeriu que recortassem os peixes carimbados para pescar com a mãozinha de silicone e, então, ajudou a criança a recortar. Após ser solicitada, B. colocava os peixes recortados “dentro” do cesto (lago). A pesquisadora também desenhou e recortou dois peixes "grandes", visto que os peixes carimbados eram “pequenos”. Após pescarem, colocavam os peixes pescados no lado de "fora” do cesto, para que pudessem contar. Em um outro atendimento, no qual a criança escolheu brincar com os carimbos, ela estava bastante sonolenta, apresentando dificuldades em manter-se atenta à atividade. Foram trabalhados os conceitos de "dentro", ao retirarem os carimbos da caixa, “metade” e "lado", visto que a pesquisadora cortou a cartolina e colocou cada metade de um lado da mesa, para que carimbassem peixes em uma metade e outros bichos, na outra metade da folha. A criança escolheu qual peixe carimbaria "primeiro”. Após serem mostrados, a criança soube identificar os carimbos de alguns bichos.

Ao brincar com a massinha, a criança escolheu fazer uma minhoca. A pesquisadora a ajudou e, então, cortaram a minhoca ao “meio”. Depois, a criança escolheu fazer bolinhas, fazendo bolas "grandes” e "pequenas". Decidiram amassar as bolas para fazerem bichinhos com as forminhas. A pesquisadora mostrou que, "primeiro”, era necessário amassar e alisar para, “depois”, fazerem os bichos. A pesquisadora ia nomeando as forminhas que a criança pegava, pois esta parecia não fazer distinção entre as figuras. A criança escolhia de que "lado" ficaria cada bicho. Colocaram o peixe no “centro” do lago (um círculo de cartolina) e também fizeram 
“muitos” outros peixes para colocar no lago. Fizeram uma casa e uma maçã para “cada” bicho. Colocaram os bichos "perto” do lago, então, a pesquisadora comentou que os bichos estavam “em volta” deste.

No início de uma sessão, foi realizada a brincadeira da Caça ao Tesouro, na qual foram trabalhados os seguintes conceitos: “entre”, “debaixo”, “atrás”, “lado direito”, “em cima”, “centro" e "dentro". A pesquisadora sempre perguntava para a criança onde estava o objeto mostrado no desenho. Após ganhar o doce, a criança foi perguntada se preferia comê-lo "agora" ou “depois" e ela preferiu comer depois.

B. brincou uma única vez com os carrinhos, retirando-os da lata e colocando-os do "lado". A pesquisadora colocou a ponte de papelão sobre a mesa e os cestos deitados à frente, dizendo que eram garagens. Após ser demonstrado, a criança soltava os carrinhos na ponte para que caíssem “dentro” das garagens. Depois, os puxava de volta pelos barbantes; enquanto isso a pesquisadora comentava que o carrinho estava "subindo", chegava "em cima" da ponte, e depois “descia”. A criança, por iniciativa própria, começou a deixar os carros rolarem em sua própria direção. A pesquisadora colocou, com a ajuda da criança, os dedoches da turma da Mônica encaixados nos carros. Indicou que alguns carrinhos estavam “vazios”, então B. colocou bonecos nestes. Após colocarem um boneco em “cada” carrinho, colocavam-nos ao lado da ponte, "perto” do posto de gasolina. Os carros foram colocados em cima da ponte para que a criança empurrasse e, em seguida, puxasse-os pelos cordões.

Na brincadeira com o Monte Castelo, a pesquisadora colocou um pouco de peças de um "lado" e um pouco do outro lado. Mostrava-lhe o que era cada tipo de peça e a ajudava a montar, entretanto, deixava-a experimentar qual peça encaixava em qual. A criança era questionada se gostaria de fazer uma casa, um prédio “alto” ou um "baixo”, "grande” ou "pequeno”. Os dedoches foram colocados "dentro" das casas e foi comentado que havia "muitos” bonecos. 
Quando escolhia um prédio, era questionada se o boneco moraria “em cima” ou “embaixo”. Foram-lhe mostradas as casas que estavam "vazias".

Em um outro atendimento, B. brincou com os bichinhos para montar de massinha. A criança foi solicitada a retirar as peças de “dentro” da caixa e a escolher onde ficariam as figuras das patas, dos rabos e das cabeças: de um "lado" da mesa, do outro lado ou no "meio". Solicitada a identificar as patas e os rabos pertencentes a cada bicho escolhido, ela errava em alguns momentos. Para fazer o corpo dos animais, a pesquisadora colocava a massinha entre as mãos da criança e lhe mostrava como movê-las para fazer uma bolinha ou um rolinho. Em seguida, direcionava sua mão para que encaixasse as outras partes do corpo. Após fazer cada bicho, B. escolhia de que lado da mesa o colocaria.

B. também brincou uma única vez com o zoológico. Foi solicitada a retirar as peças da caixa e a colocá-las “dentro” da bacia. Começou a espalhar os bichos pelo cenário, escolhendo onde colocaria cada bicho: de um "lado", do outro, "longe" ou "perto". A criança colocava os bichos dentro das cercas. Depois de espalharem todos os bichos, levaram os carros para andarem “em volta” do parque.

Desde o início, foi possível observar que a criança usava quase que exclusivamente a mão esquerda. Utilizava a outra mão apenas se fosse solicitada ou se fosse necessário. Sua mãe foi orientada, então, a favorecer o uso desta mão, proporcionando atividades que exijam o uso de ambas as mãos, por exemplo, segurando uma bacia com uma mão e retirando as bolas com a outra, ou oferecendo bolas grandes, de modo que não seja necessário o comando verbal para que use a mão direita. Em todas as brincadeiras era favorecido, deste modo, o uso deste membro superior. Algumas vezes, o cesto com as bolas era colocado em uma posição que favorecia o alcance com o braço direito, ou o objeto era oferecido na direção da mão direita. Com o decorrer 
dos atendimentos, foi possível perceber que a criança passou a usar ambas as mãos durante as tarefas, sem a necessidade da intervenção da pesquisadora para que isso ocorresse.

B. apresentava um medo excessivo quando sentia algum risco de queda, como ao sentar-se numa cadeirinha ou ficar de pé com o auxílio de alguém. Nestas situações, a criança começava a rir, mas era possível observar que esta era uma reação ao medo. A pesquisadora, então, procurava sempre fazer com que ela se sentisse mais segura, adequando seu posicionamento com antiderrapantes e outros materiais, além de manter objetos nos quais pudesse se segurar. Aos poucos, no decorrer das brincadeiras, B. começou a demonstrar maior segurança nestas ocasiões.

B. é bastante dependente da mãe para todas as trocas posturais, por este motivo, sempre que necessário mudar de posição, a pesquisadora solicitava e facilitava a participação da criança nestes movimentos. Colocava-a no tablado e pedia para que se arrastasse até o local onde brincaria, apoiava seu braço para que ajudasse a se sentar, pedia para que trocasse passos ao ficar de pé, etc.

Visto que B. não mantém a atenção facilmente, tem o costume de manipular um objeto ou fazer uma atividade olhando para outros lugares. Era necessário, então, pedir sempre que olhasse para o que estava fazendo. Devido a esta dispersão da atenção, era necessário que a pesquisadora sempre direcionasse a atividade da criança, perguntando o que faria, dando sugestões ou nomeando o que era feito, pois, caso contrário, quando tentava deixar que ela direcionasse a brincadeira de maneira mais livre, B. perdia o interesse pela atividade e dirigia atenção para o ambiente ao redor.

Depois que B. escolhia com o que queria brincar, a terapeuta lhe pedia que a ajudasse a colocar os brinquedos não escolhidos debaixo do tablado. Após brincar, ela também ajudava a guardar o brinquedo utilizado debaixo do tablado, em cima da mesa ou dentro do armário. Ao guardar os objetos, a pesquisadora sempre solicitava que ela guardasse um tipo de brinquedo em 
um recipiente e, outro tipo, em outro recipiente (por exemplo, as bolas grandes na lata e as pequenas na caixa). Deste modo, era possível estimular o desenvolvimento da classificação, habilidade relacionada ao processo de formação de conceitos, visto que, neste, é fundamental a distinção entre objetos de diferentes classes. No início, observava-se que B. confundia os objetos a serem guardados, colocando-os nos recipientes incorretos; entretanto, após ser corrigida e, no decorrer das sessões, notou-se que esta passou a identificar os objetos distintos, guardando-os corretamente.

De acordo com sua mãe, B. aprendeu muitas coisas no decorrer da pesquisa. Estaria mais ‘esperta’ para brincar. Já não queria mais brincar com a irmã, preferindo brincar sozinha; segundo a mãe, quando B. brincava com a irmã, esta fazia quase todas as ações da brincadeira, de modo que B. participava passivamente. Ou seja, negar-se a brincar com a irmã significava que B. estava apresentando uma postura mais ativa em suas brincadeiras. A criança passou, também, a reproduzir em casa algumas brincadeiras feitas nos atendimentos, tais como utilizar as bacias da mãe para colocar bolinhas. A mãe também relatou que, após as sessões, B. passou a falar sozinha ao brincar, dizendo o que fazer e onde colocar os objetos, a exemplo de como era feito pela pesquisadora, que nomeava as ações da criança.

B. compareceu a todos os 16 atendimentos oferecidos. Contudo, visto que os testes foram realizados no início e no final da pesquisa, as brincadeiras que envolviam conceitos foram realizadas em 14 atendimentos. A Tabela 6.10 apresenta o número de sessões nas quais estes conceitos foram trabalhados. 
Tabela 6.10 - Sujeito B.: número e porcentagem de sessões em que os conceitos foram trabalhados nas brincadeiras.

\begin{tabular}{|l|c|c|}
\hline Conceito & No. de sessões & \% de sessões \\
\hline Debaixo & 8 & 57,1 \\
\hline Depois & 4 & 28,6 \\
\hline Muitos & 4 & 28,6 \\
\hline Centro & 2 & 14,3 \\
\hline Em volta & 2 & 14,3 \\
\hline Quase & 1 & 7,1 \\
\hline Entre & 1 & 7,1 \\
\hline Lado direito & 1 & 7,1 \\
\hline Agora & 1 & 7,1 \\
\hline Tamanho médio & 1 & 7,1 \\
\hline Metade & 1 & 7,1 \\
\hline Logo & - & - \\
\hline Menos & - & - \\
\hline Cedo & - & - \\
\hline Nunca & - & - \\
\hline
\end{tabular}

Conforme pode ser observado na tabela acima, o conceito "tamanho médio" foi trabalhado em apenas um atendimento; o conceito mais trabalhado foi o de “debaixo" (57,1\% dos atendimentos), seguido pelos conceitos de “depois” e “muitos” (28,6\%).

Além destes conceitos avaliados por meio do Teste de Boehm, outros conceitos também foram utilizados durante as brincadeiras. Estes são apresentados na Tabela 6.11. 
Tabela 6.11 - Sujeito B.: conceitos trabalhados nas brincadeiras, mas não avaliados pelo Teste de Boehm.

\begin{tabular}{|l|c|c|}
\hline Conceito & No. de sessões & \% de sessões \\
\hline Grande & 10 & 66,7 \\
\hline Pequeno & 9 & 60 \\
\hline Dentro & 8 & 53,3 \\
\hline Lado & 8 & 53,3 \\
\hline Perto & 4 & 26,7 \\
\hline De cima ou em cima & 4 & 26,7 \\
\hline Fora & 3 & 20 \\
\hline Longe & 3 & 20 \\
\hline Primeiro & 3 & 20 \\
\hline Vazio & 3 & 20 \\
\hline Atrás & 2 & 13,3 \\
\hline Mais & 2 & 13,3 \\
\hline Alto & 2 & 13,3 \\
\hline Sobre & 2 & 13,3 \\
\hline Meio & 2 & 13,3 \\
\hline Cada & 2 & 13,3 \\
\hline Subir & 1 & 6,7 \\
\hline Descer & 1 & 6,7 \\
\hline Baixo & 1 & 6,7 \\
\hline Poucos & 1 & 6,7 \\
\hline Cheio & 1 & 6,7 \\
\hline Antes & 1 & 6,7 \\
\hline Forte & 1 & 6,7 \\
\hline Fraco & 1 & 6,7 \\
\hline Frente & & 6,7 \\
\hline
\end{tabular}

Como é possível observar, dentre estes conceitos, os mais trabalhados foram "grande" (66,7\% dos atendimentos) e "pequeno" (60\%), seguidos pelos conceitos de "dentro" e "lado" $(53,3 \%)$.

No início da pesquisa, foi observado que a criança não sabia identificar objetos grandes e pequenos. Por este motivo, optou-se, inicialmente, por utilizar apenas dois tamanhos de objetos para que, depois que a criança aprendesse os conceitos de "grande" e "pequeno", fossem incluídos objetos de tamanho médio. Foi possível observar que, com o decorrer dos atendimentos, a criança passou a reconhecer com maior facilidade os objetos grandes e pequenos, 
embora ainda necessitasse de ajuda em alguns momentos. Por fim, B. já apresentava maior segurança no que diz respeito a estes conceitos, utilizando-os, inclusive, em atividades domiciliares. Embora o conceito de tamanho médio tenha sido pouco trabalhado, devido à dificuldade inicialmente apresentada pela criança quanto aos conceitos ainda mais básicos, em um atendimento, após ser trabalhado o conceito de "tamanho médio”, a criança disse que jogaria a bola na bacia média e o fez corretamente. Este fato mostra que, embora o aprendizado deste conceito estivesse apenas se iniciando, o fato de ter aprendido a utilizar os outros dois conceitos de tamanho (grande e pequeno) em diferentes situações, favoreceu uma compreensão mais rápida deste conceito intermediário (tamanho médio).

O desempenho da criança no teste de avaliação de conceitos é apresentado na Tabela 6.12.

Tabela 6.12 - Sujeito B.: resultados do pré e pós-teste, no Teste de Boehm.

\begin{tabular}{|c|c|c|}
\hline Conceitos & Pré-teste & Pós-teste \\
\hline 1 - Inst. Sapato & A & A \\
\hline 2 - Inst. Banana & A & A \\
\hline 3 - Inst. Carro & A & A \\
\hline 4 - Inst. Mesa & $\mathrm{E}$ & $E$ \\
\hline 5 - Inst. Copo & A & A \\
\hline 6 - Inst. Cachorro & A & A \\
\hline Total - instrução & 5 & 5 \\
\hline 1 - Depois & $E_{b}$ & $E_{b}$ \\
\hline 2 - Centro & $\mathrm{E}$ & $\mathrm{E}$ \\
\hline 3 -Quase & $\mathrm{E}$ & $E_{b}$ \\
\hline $4-$ Em volta & $\mathrm{E}$ & $E_{c}$ \\
\hline 5 - Cedo & $E_{b}$ & $E_{b}$ \\
\hline 6- Nunca & $E_{a}$ & $E_{a}$ \\
\hline 7 - Metade & $\mathrm{E}$ & $E_{c}$ \\
\hline 8 - Lado direito & $E_{a}$ & $E_{b}$ \\
\hline 9 - Tam. médio & A? & $E_{b}$ \\
\hline $10-$ Menos & $E_{a}$ & A? \\
\hline 11 - Entre & $\mathrm{E}$ & $E_{c}$ \\
\hline 12 - Logo & $E$ & $E_{a b}$ \\
\hline 13 - Debaixo & $E$ & A \\
\hline 14-Muitas & A? & $E_{a}$ \\
\hline 15-Agora & A? & $E_{b c}$ \\
\hline Total - acertos & 3 & 2 \\
\hline
\end{tabular}


No pré-teste, B. respondeu adequadamente à maioria dos itens de instrução, entretanto, ao iniciar o teste propriamente dito, respondia "sim" para todos os desenhos apontados pela pesquisadora. A criança não demonstrava atenção nem às perguntas da pesquisadora nem às suas próprias respostas, não sendo possível avaliar se dominava ou não os conceitos. Neste dia, sua mãe confirmou que ela apresenta dificuldades em concentrar-se nas atividades. Por considerar-se que estes acertos ocorreram ao acaso, optou-se por desconsiderá-los. Além disso, o fato dela ter errado estas questões no pós-teste, confirma que estes conceitos não eram dominados por ela. Ao contrário, os acertos nos itens de instrução parecem ser confiáveis, visto que ela errou apenas a questão referente ao conceito de “mesa”, em ambos os testes.

Embora tenha conseguido manter a atenção por maior espaço de tempo no pós-teste (talvez por ter maior vínculo com a pesquisadora ou porque a pesquisadora já a conhecia melhor, conseguindo manter mais sua atenção), os resultados ainda são duvidosos, pois não mantinha a atenção, em alguns momentos.

No pós-teste, a criança acertou o conceito de “debaixo”, o mais trabalhado no decorrer da pesquisa (em 57,1\% dos atendimentos), o que supõe que este acerto possa corresponder ao aprendizado do conceito em tela. Contudo, a criança também acertou o conceito de “menos”, que não foi trabalhado, o que indica que este acerto possa ter ocorrido por acaso ou que a criança aprendeu este conceito em outras situações. As questões referentes aos conceitos de “depois” e “muitos” (trabalhados em 28,6\% dos atendimentos), não foram acertadas pela criança. Os demais conceitos foram pouco trabalhados.

Segundo observações e relatos da mãe, B. aprendeu os conceitos de "grande" (trabalhado em 66,7\% dos atendimentos) e “pequeno” (60\%), pois passou a utilizá-los em situações cotidianas, como ao escolher a colher que gostaria de utilizar durante o almoço. 


\subsection{4 - FR. o competidor}

FR., sexo masculino, 10 anos e 11 meses de idade, apresenta seqüelas de paralisia cerebral diparética espástica, realizando marcha com apoio (segurando-se no encosto da cadeira de rodas) e conseguindo realizar as trocas posturais, embora com alguma dificuldade. Apresenta limitação na função com o membro superior esquerdo, mas consegue manipular objetos grandes e pequenos com o outro membro. Apresenta dificuldades na pronúncia de algumas palavras, mas tem uma fala compreensível e adequada às situações, sendo bastante comunicativo.

A gestação de FR. não foi planejada e ocorreram intercorrências, contudo, o parto foi normal. A descoberta da deficiência da criança ocorreu quando esta se encontrava com seis meses de vida; a mãe relata que compreendeu logo, não tendo muitos problemas em aceitar o diagnóstico. O desenvolvimento foi muito ruim (sic), melhorando somente após o início do tratamento de hidroterapia, o qual realiza até o atual momento. A criança já realizou também tratamentos de fisioterapia, fonoaudiologia, psicologia e terapia ocupacional, no Lar Escola São Francisco (SP).

Seus pais cursaram até a $5^{\mathrm{a}}$ série do ensino fundamental e a criança freqüenta a $1^{\mathrm{a}}$ série em uma escola comum. Mora com os pais em uma casa alugada, de dois cômodos, e não possui irmãos. A criança participa dos passeios e festas familiares e brinca com outras crianças, sendo tratada de maneira normal pelos parentes (sic).

FR. gosta de brincar com carrinho, bola, vídeo-game e quebra-cabeça, mas, segundo a mãe, não consegue montá-lo. Também brinca com lápis, cola, caderno e tesourinha. Segundo as observações de sua mãe, FR. não se mantém concentrado em uma mesma brincadeira, sempre mudando de atividade, contudo inventa novas formas de usar os objetos, usa a imaginação e brinca da maneira esperada com cada tipo de brinquedo. Prefere brincar com bola e não evita 
nenhum tipo de brincadeira. Brinca sozinho e com outras crianças (quando alguém o visita), sendo que, às vezes, brinca com seus pais. Prefere brincar com poucas pessoas, pois é tímido. Durante a semana, brinca quando chega da aula e quando não tem dever de casa. Nos finais de semana, brinca por bastante tempo, durante todo o dia.

A criança demonstrou, desde o início da pesquisa, grande interesse pelas brincadeiras oferecidas, o que se refletiu na diversidade das brincadeiras escolhidas por ela. No decorrer dos atendimentos, realizou dez diferentes tipos de brincadeiras, repetindo apenas duas delas: o jogo da memória e a pescaria.

A Tabela 6.13 apresenta as brincadeiras oferecidas e as brincadeiras escolhidas pela criança.

Tabela 6.13 - Sujeito FR.: brincadeiras oferecidas e brincadeiras escolhidas.

\begin{tabular}{|l|c|c|}
\hline Brincadeiras & Oferecidas & Escolhidas \\
\hline Carimbos de peixes & 3 & 1 \\
\hline Pescaria de papel & 1 & 1 \\
\hline Jogo da memória & 2 & 2 \\
\hline Varetas gigantes & 2 & 1 \\
\hline Jogo de argolas & 1 & - \\
\hline Vira Lata & 3 & - \\
\hline Futebol de bolinhas de gude & 2 & 1 \\
\hline Bolinhas coloridas & 4 & - \\
\hline Massinha & 5 & 1 \\
\hline Carrinhos de corrida & 3 & 1 \\
\hline Trilhos de trem & 1 & - \\
\hline Bichinhos de massinha & 2 & - \\
\hline Monte Castelo & 3 & - \\
\hline Zoológico & 3 & 1 \\
\hline Dedoches & 1 & 1 \\
\hline Rolos e cones para derrubar & 1 & 1 \\
\hline Pescaria & 2 & 2 \\
\hline Macacão que gruda & 1 & - \\
\hline
\end{tabular}

Em dois atendimentos não consecutivos FR. brincou com o jogo da memória dos "Ursinhos e seus Amigos” (jogo da memória que possui ursinhos para encaixar no tabuleiro, escondendo os desenhos dos bichos). Antes de iniciar, ainda estando todos os bichos à mostra, a pesquisadora 
pediu para que ele achasse os "pares”, sendo nomeados os bichos que não reconhecia. Foi-lhe explicado que precisavam, “antes”, esconder os bichos com os ursinhos para, “depois”, encontrarem os pares. Foi colocado um pouco de ursinhos de cada "lado", para que fossem encaixados no tabuleiro com a mão correspondente àquele lado. Após iniciarem o jogo, os ursinhos ganhos pela criança ao encontrar os pares eram colocados no "lado direito" e, os da pesquisadora, no "lado esquerdo". Ao procurarem pelos pares, a pesquisadora dava dicas sobre o lado em que o bicho se encontrava, também sendo dito se estaria "perto” de outro bicho, "entre” outros dois, no “centro” (ou no “meio”) do tabuleiro, “em cima” ou “embaixo”.

A criança também brincou duas vezes com a pescaria, sendo dois atendimentos seguidos. FR. escolheu em qual bacia seria colocada a água para fazer o lago, na "pequena”, na de “tamanho médio” ou na "grande”. Colocaram os peixes “dentro” da bacia com água. As demais bacias eram utilizadas para colocar os peixes dos participantes, estando uma no "lado direito" e a outra, no "lado esquerdo". Às vezes, trocavam as bacias de "lado”. A bacia com água era colocada “entre” as demais. Era combinado que só poderiam jogar o anzol na água “depois” que falassem já. Contavam para ver quantos peixes cada um havia pescado.

Em um atendimento, a criança escolheu brincar com os carimbos, embora não soubesse como utilizá-los. Foi combinado que carimbariam alguns peixes para, na semana seguinte, brincarem de pescar. Conforme sugerido pela pesquisadora, a criança utilizou os carimbos de cabo "grande” com a mão de um "lado" (a mão esquerda, com a qual a criança apresenta dificuldades no manuseio) e os carimbos de cabo "pequeno", com a outra mão, do outro "lado". Após carimbarem, a criança recortou os peixes com a tesoura. A pesquisadora a ajudava a segurar o papel com a mão esquerda, estimulando o seu uso. Conforme combinado, na semana seguinte, FR. quis brincar de pescar os peixes carimbados. Recortaram o restante dos peixes, sendo dito que “antes” era necessário recortar para que, “depois”, pudessem pescar. Visto que estes peixes 
eram “pequenos”, a pesquisadora também fez peixes “grandes” e “médios”. Colocaram os peixes no "lago" (um cesto) e começaram a pescá-los com a mãozinha de silicone. A criança sempre contava para identificar quem possuía “mais” e “menos” peixes de cada tamanho.

Ao brincar com a massinha, FR. quis usar a massa "grande", ao invés das massas “pequenas" e coloridas. Cortaram a massa ao "meio". Foram-lhe explicadas as etapas da brincadeira, sendo sempre utilizado o conceito de “depois”. Após nomearem as forminhas, a criança escolhia qual figura queria fazer e a pesquisadora pedia para que colocasse a forminha no “centro" da massa alisada, indicando-lhe o local. Colocavam as figuras feitas no "lado direito" da mesa. A criança quis fazer um boneco, então, ao fazerem-no, iam discutindo se os tamanhos da cabeça, dos braços e das pernas estavam adequados. Decidiram fazer uma cidade. Fizeram um círculo de papel, que seria a praça. Escolheram as figuras de massinha que ficariam no "centro" da praça e “em volta” dela.

Em uma sessão, a criança viu um brinquedo e disse que queria brincar com bolinhas. A pesquisadora disse, então, que poderiam brincar com o jogo de bilhar (que tem bolas bem “pequenas”), com o futebol de bolinhas de gude (que tem bolas “médias”) ou com a lata de bolas (que tem bolas “grandes”). Ele escolheu o futebol de bolinhas de gude. Dividiram "metade” das bolinhas para cada um. Decidiram quem começaria jogando e quem jogaria “depois”. Combinaram de que "lado" cada um faria gol, do "lado direito" ou do "esquerdo", com a bola saindo do "centro" do campo. Davam petelecos na bola até acertar o gol, cada um a sua vez. A criança quis incluir as bolas de gude pequenas e as médias no jogo. Jogaram novamente, iniciando o jogo com as bolas pequenas e, em seguida, as médias e as grandes. Quando ele levava a bola na direção contrária, a pesquisadora lembrava-o de que seu gol era à esquerda. Ele disse que deveriam acertar todos os pinos antes de jogar para o gol, então combinaram que jogariam 
cada vez de um jeito. Ele pediu para jogar com todas as bolinhas de gude, mas a pesquisadora disse não ser possível, por haver “muitas” bolinhas (mais de 50 unidades).

Ao brincar com as varetas gigantes, foi necessário brincarem no chão, visto que estas eram muito "grandes". A criança decidiu de que "lado" jogaria as varetas; combinaram quem começaria e quem jogaria “depois”. Decidiram que as varetas que a pesquisadora pegasse ficariam de um lado e as dele, do outro, sendo, às vezes, nomeados os lados “direito” e “esquerdo”. A criança já conhecia as regras da brincadeira. Separaram todas as varetas pelas cores e contaram quem possuía "mais” e quem possuía "menos” de cada cor. Em seguida, preferiram brincar de derrubar, com as varetas, alguns rolos e cones. Estes foram posicionados de modo a favorecer o uso dos conceitos de "lado direito”, “lado esquerdo”, “entre”, “centro” e “em volta”. Combinaram a seqüência na qual os objetos seriam derrubados, sendo trabalhados os conceitos de “depois” e "por último”. Ele ria bastante enquanto derrubavam os objetos. Depois, quis colocar as varetas “dentro” dos rolos. Colocaram-nas e, com dificuldade, conseguiram deixar o rolo de pé; enquanto isso, a criança dava gargalhada devido ao risco de queda do rolo.

No início de um atendimento, foi realizada a brincadeira da Caça ao Tesouro, que incluía os conceitos: “entre”, “debaixo”, “atrás”, “lado direito”, “em cima”, “centro” e “dentro”. Após esta brincadeira, FR. escolheu brincar com os carrinhos de corrida. Sentaram-se no chão e colocaram as faixas de largada e de chegada. Ele escolheu de que "lado” seu carro correria, do "lado direito" ou "esquerdo". A pesquisadora colocou um pedaço de fita crepe "entre” os carros, para que um não passasse para o lado do outro. Foi necessário insistir para que ele só puxasse o carro depois que dissessem já. Combinaram que só poderiam puxar os barbantes dos carros com uma única mão, visto a dificuldade da criança em puxar com ambas as mãos. Colocaram o túnel e a ponte de papelão, para que o carro passasse “por cima” da ponte e “por baixo” do túnel. 
FR. também brincou, em outro atendimento, com o zoológico. A pesquisadora pediu para que ele retirasse tudo de "dentro" da caixa e colocasse os bichos em um cesto, de um "lado", e as demais peças do jogo, no outro cesto, do outro lado da mesa. Separaram os bichos pelos pares e os espalharam pelo tabuleiro. A pesquisadora comentava qual bicho estava no "lado direito", no "lado esquerdo" ou no “centro" do parque. Colocaram as cercas "em volta” dos bichos e a pesquisadora lhe mostrou que, onde havia “muitos” bichos, a cerca deveria ser "maior”. Foi-lhe mostrado que havia "mais" bichos de um lado do parque e "menos" do outro. Colocaram os bonecos dos dedoches para visitar o parque e a criança sugeriu utilizarem os carrinhos para levar os bonecos. Levaram os carros para andarem "em volta” do parque.

No decorrer dos atendimentos, FR. apresentou comportamentos inadequados em muitas situações, sendo necessário chamar sua atenção. Quando chegava antes da hora, ficava batendo à porta, atrapalhando os atendimentos de outro paciente, embora tenha sido dito que precisava aguardar ser chamado. Em alguns momentos, manipulou bruscamente ou com força alguns brinquedos, sendo necessário alertá-lo de que acabaria quebrando-os. FR. também mentiu algumas vezes, escondendo um brinquedo ou trapaceando nos jogos. Era necessário insistir para que ajudasse a guardar os brinquedos utilizados. A pesquisadora sempre conversava com ele e salientava o que era permitido ou não fazer. Com o decorrer dos atendimentos, percebeu-se que FR. já respeitava melhor os limites impostos, bem como as regras das brincadeiras.

FR. também demonstrava dificuldade em perder nos jogos, querendo ganhar sempre. A pesquisadora conversava, explicando-lhe que às vezes perdemos e às vezes ganhamos. Aos poucos, a criança foi melhorando neste aspecto, demonstrando lidar melhor com as frustrações.

Apesar de ser estimulada a autonomia da criança, de modo que esta era sempre solicitada a escolher o que gostaria ou não de fazer, não era permitido que a criança desrespeitasse a pesquisadora, pois, o seu direito de escolha também deveria ser respeitado. Como exemplo disso, 
é possível mencionar o atendimento no qual a criança escolheu o seu carrinho de corrida e a pesquisadora escolheu o dela. FR. disse que não, que o carrinho da pesquisadora seria outro. Contudo, a pesquisadora lhe explicou que ele já havia escolhido o seu carrinho, então a pesquisadora escolheria com qual gostaria de brincar.

Todos os brinquedos que a criança via, pedia para sua mãe comprar e ela dizia que sim. A pesquisadora explicou para a criança que ninguém pode comprar tudo que quer e que ele poderia brincar com os brinquedos quando fosse às sessões de terapia ocupacional, não sendo necessário comprar brinquedos iguais. No início, a criança também pedia para que a pesquisadora lhe desse os brinquedos utilizados na sessão. Ela lhe explicava que não poderia, visto que os mesmos eram da instituição; assim, aos poucos, a criança foi perdendo este hábito.

Embora fosse dada preferência para a participação dos pais durantes os atendimentos, a fim de que estes pudessem receber algumas orientações e enriquecer o repertório de possibilidades de interação com seus filhos, não foi possível permitir que a mãe de FR. permanecesse na sala durante as sessões. Ela demandava muito a atenção da pesquisadora, fazendo perguntas sobre vários assuntos, interrompendo as atividades e brigando com seu filho quando este fazia algo de errado. Foi combinado que ela poderia entrar ao final de cada sessão, para que lhe fosse explicado o que havia sido feito e para que tirasse suas dúvidas. Visto que FR. não realizava atendimentos de terapia ocupacional em outra instituição, sua mãe solicitava outras intervenções (confecção de órteses, prescrição de cadeiras de rodas, relatório para a escola, entre outros), as quais foram atendidas em horário distinto aos destinados à pesquisa.

Apesar de não ser o objetivo central dos atendimentos, as brincadeiras também favoreceram o uso do membro superior esquerdo, visto que a criança costumava utilizar apenas o membro direito. Neste sentido, eram incluídas algumas regras nas brincadeiras de que algo deveria ser feito com cada mão, ou eram realizadas tarefas que exigiam o uso de ambas ao mesmo tempo. 
Visto que a criança apresenta sincinesia (movimento em espelho), a pesquisadora pedia para que segurasse algo com uma mão enquanto realizasse um movimento diferente com a outra (por exemplo, segurar a varinha com a mão esquerda enquanto retirava o peixe do anzol com a mão direita), visando dissociar os movimentos. Sua mãe também era orientada a estimular de maneira indireta o uso da mão esquerda, sem que fosse necessário pedir diretamente ou brigar com a criança, como costumava fazer.

Visando estimular o desenvolvimento da noção de lateralidade e dos conceitos a ela referentes, a pesquisadora sugeria, no decorrer das brincadeiras, que a criança fizesse algo com uma mão e, depois, com a outra. Em outras ocasiões, colocava um tipo de objeto de um lado e outro tipo do outro lado. No início, os lados não eram nomeados, mas, aos poucos, foram incluídos os conceitos de "lado direito" e "lado esquerdo".

Ao organizarem os brinquedos ou no momento de guardá-los, a pesquisadora sempre pedia para que a criança colocasse um tipo de objeto em uma caixa (ou cesto), de um lado da mesa, e outro tipo de objeto em outra caixa, do outro lado. Assim, além de estimular o desenvolvimento da noção de lateralidade, também era possível estimular a diferenciação e classificação dos objetos. Em um atendimento, a criança se atrapalhou um pouco no início desta tarefa, contudo, após ser ajudada, passou a selecionar os objetos adequadamente.

FR. compareceu a 13 dos $15^{46}$ atendimentos oferecidos. Visto que o pré-teste e o pós-teste foram realizados, respectivamente, no início e no final da pesquisa, os conceitos da pesquisa puderam ser trabalhados por meio das brincadeiras em apenas 11 atendimentos. O número de sessões nas quais estes conceitos foram utilizados é apresentado na Tabela 6.14.

\footnotetext{
${ }^{46}$ Diferentemente das demais crianças da pesquisa, não foi possível oferecer 16 atendimentos a FR. devido ao grande número de feriados ocorridos no dia da semana no qual estes atendimentos eram realizados ( 6 a feira).
} 
Tabela 6.14 - Sujeito FR.: número e porcentagem de sessões em que os conceitos foram trabalhados nas brincadeiras.

\begin{tabular}{|l|c|c|}
\hline Conceito & No. de sessões & \% de sessões \\
\hline Lado direito & 9 & 81,8 \\
\hline Centro & 7 & 63,6 \\
\hline Depois & 5 & 45,4 \\
\hline Menos & 5 & 45,4 \\
\hline Entre & 4 & 36,4 \\
\hline Tamanho médio & 4 & 36,4 \\
\hline Em volta & 3 & 27,3 \\
\hline Muitas & 2 & 18,2 \\
\hline Debaixo & 2 & 18,2 \\
\hline Metade & 1 & 9,1 \\
\hline Quase & - & - \\
\hline Logo & - & - \\
\hline Agora & - & - \\
\hline Nunca & - & - \\
\hline Cedo & - & - \\
\hline
\end{tabular}

Por esta tabela é possível observar que os conceitos mais trabalhados durante a pesquisa foram os de "lado direito" (incluído em 81,8\% dos atendimentos) e "centro" (trabalhado em 63,6\% dos atendimentos), seguidos pelos conceitos de “menos” e “depois” (45,4\%), "tamanho médio" e "entre" (36,4\%).

Além destes, outros conceitos também foram incluídos nas brincadeiras, de acordo com as atividades realizadas. Estes conceitos são apresentados na Tabela 6.15. 
Tabela 6.15 - Sujeito FR.: conceitos trabalhados nas brincadeiras, mas não avaliados pelo Teste de Boehm.

\begin{tabular}{|l|c|c|}
\hline Conceito & No. de sessões & \% de sessões \\
\hline Lado & 9 & 81,8 \\
\hline Lado esquerdo & 8 & 72,7 \\
\hline Grande & 7 & 63,6 \\
\hline Mais & 6 & 54,5 \\
\hline Pequeno & 6 & 54,5 \\
\hline Dentro & 4 & 36,4 \\
\hline Antes & 2 & 18,2 \\
\hline Par & 2 & 18,2 \\
\hline Meio & 2 & 18,2 \\
\hline Em cima & 2 & 18,2 \\
\hline Perto & 1 & 9,1 \\
\hline Último & 1 & 9,1 \\
\hline Atrás & 1 & 9,1 \\
\hline Por baixo & 1 & 9,1 \\
\hline Maior & 1 & 9,1 \\
\hline
\end{tabular}

Como é possível observar, dentre estes conceitos, os mais trabalhados foram os conceitos de "lado" e "lado esquerdo" (trabalhados em 81,8\% e 72,7\% dos atendimentos, respectivamente), visto que estes eram relacionados ao conceito de "lado direito". Em seguida, os conceitos mais trabalhados foram os de "grande" (63,6\%) e "pequeno" (54,5\%), por serem relacionados ao conceito de "tamanho médio". O conceito de “mais" também foi trabalhado em 54,5\% das sessões, por ser tomado em oposição ao conceito de “menos”.

Conforme avaliado pelo pré-teste, no decorrer das brincadeiras foi possível perceber que a criança dominava o conceito de "menos" em quase todas as situações que envolvessem um número pequeno de objetos, apresentando dificuldades apenas quando a comparação envolvia grupos com mais de dez itens. Deste modo, foi possível observar que o conceito estaria em fase de aprendizagem, visto que o desempenho da criança melhorava em cada sessão em que os conceitos de "mais" e de “menos" eram utilizados. Por meio das brincadeiras, também foi possível perceber que a criança não dominava os conceitos de "tamanho médio”, “meio”, "lado 
direito” e “centro”. Após serem trabalhados nas brincadeiras, a criança conseguiu identificar, em uma sessão, os objetos situados no "centro" e no "lado direito”, o que indica que estes estavam sendo aprendidos. Apesar de dominar o conceito de "metade” na maioria das situações, a criança não soube resolver sem ajuda o problema de dividir objetos em número impar pela metade.

Tanto no pré-teste quanto no pós-teste, FR. respondeu de maneira adequada, compreendendo o que foi proposto. Estava bastante atento e interessado em acertar as questões. A Tabela 6.16 apresenta os resultados obtidos pela criança em ambos os testes.

Tabela 6.16 - Sujeito FR.: resultados do pré e pós-teste, no Teste de Boehm.

\begin{tabular}{|c|c|c|}
\hline Conceitos & Pré-teste & Pós-teste \\
\hline 1 - Inst. Sapato & A & A \\
\hline 2 - Inst. Banana & $\mathrm{A}$ & $\mathrm{A}$ \\
\hline 3 - Inst. Carro & A & A \\
\hline 4 - Inst. Mesa & A & A \\
\hline 5 - Inst. Copo & A & A \\
\hline 6 - Inst. Cachorro & A & A \\
\hline Total - instrução & 6 & 6 \\
\hline 1 - Depois & $\mathrm{E}_{\mathrm{c}}$ & $E_{c}$ \\
\hline 2 - Centro & $\mathrm{E}$ & A \\
\hline 3-Quase & A & A \\
\hline $4-$ Em volta & $E_{c}$ & A \\
\hline 5 - Cedo & $\mathrm{A}$ & $\mathrm{A}$ \\
\hline 6 - Nunca & $E_{c}$ & $E_{c}$ \\
\hline 7 - Metade & A & A \\
\hline 8 - Lado direito & A? & A \\
\hline 9 - Tam. médio & $E_{b}$ & $E_{b}$ \\
\hline $10-$ Menos & $\mathrm{A}$ & $\mathrm{A}$ \\
\hline 11 - Entre & $\mathrm{E}_{\mathrm{c}}$ & A \\
\hline 12 - Logo & $\mathrm{A}$ & $\mathrm{A}$ \\
\hline 13 - Debaixo & $\mathrm{A}$ & $\mathrm{A}$ \\
\hline 14-Muitas & A & A \\
\hline 15 - Agora & A & $\mathrm{A}$ \\
\hline Total - acertos & 9 & 12 \\
\hline
\end{tabular}

No pré-teste, FR. demonstrou dúvidas ao responder à questão referente ao conceito de “lado direito”, mas acertou, parecendo marcar a opção que estava mais próxima à mão utilizada para 
apontar. A pesquisadora perguntou, então, qual desenho estava no lado esquerdo, e ele apontou para o que estava no meio; foi perguntado novamente sobre qual desenho estava do lado direito e ele mostrou o que estava à esquerda. Este fato, além de indicar que a criança não dominava o conceito de "lado direito", também indicou que não dominava o conceito de "lado", por ter apontado para um item que se encontrava entre os demais, não correspondendo a nenhum dos lados. Depois, ao observar suas respostas, a pesquisadora percebeu que $67 \%$ de seus erros e $50 \%$ de seus acertos ocorreram com a indicação das opções que estavam no lado direito das fichas do teste. Portanto, o fato de utilizar apenas a mão direita pode ter interferido nas respostas da criança, fazendo com que acertasse alguns conceitos que não dominava pelo simples fato de algumas respostas corretas se encontrarem à direita das cartelas.

No pós-teste, a criança não errou nenhuma questão que havia acertado anteriormente, manteve alguns erros e acertou mais três questões, parecendo ter aprendido os conceitos a elas correspondentes (“centro”, “em volta” e “entre”).

Dentre os conceitos aprendidos pela criança no decorrer da pesquisa, o conceito de "centro" foi o mais trabalhado (em 63,6\% dos atendimentos), seguido pelo conceito de "entre" $(36,4 \%)$ e pelo conceito de “em volta” (27,3\%). No pós-teste, a criança errou os conceitos de “depois” (trabalhado em 45,4\% dos atendimentos), “tamanho médio” (36,4\%) e "nunca” (não trabalhado em nenhum atendimento).

FR. acertou novamente a questão referente ao conceito de "lado direito", mas é possível pensar que, assim como ocorrido no pré-teste, ele tenha apontado para o desenho que estava mais próximo à mão que mais utiliza. Contudo, é possível afirmar que a criança tenha avançado no desenvolvimento deste conceito no transcorrer da pesquisa, visto que este foi trabalhado em 81,8\% dos atendimentos. Esta hipótese pode ser sustentada pelo fato de que, em um atendimento, 
após ser trabalhado o conceito por meio de brincadeiras, FR. soube indicar adequadamente o objeto que se encontrava no "lado direito".

Quanto aos demais itens do pós-teste, dois de seus três erros ainda ocorreram na opção C (ou seja, correspondentes ao lado direito). Contudo, no que se refere à questão correspondente ao conceito de “depois”, há a possibilidade de que a criança tenha associado este ao último desenho da cartela. Quanto ao conceito de "tamanho médio”, o fato de a criança ter escolhido, tanto no pré-teste quanto no pós-teste, o item encontrado no meio da cartela, pode indicar que FR. tenha associado o objeto intermediário (situado entre os demais) ao conceito de "médio”. De seus três novos acertos (referentes aos conceitos de “centro”, “em volta” e “entre”), nenhuma das respostas se encontrava no lado direito da placa do teste, o que torna este resultado mais confiável. Portanto, com exceção da pergunta correspondente ao conceito de "lado direito", o teste pareceu confiável para demonstrar os conceitos anteriormente dominados e os conceitos aprendidos pela criança no decorrer da pesquisa.

\subsection{5 - V. o carimbador}

V., sexo masculino, nove anos e três meses de idade, apresenta um quadro de paralisia cerebral do tipo atetóide com componente espástico, causado por infecção por citomegalovirus. Não anda com independência, mas se arrasta e consegue permanecer de joelhos, apoiando-se em algum local com as mãos. Comunica-se por sons e expressões faciais. Senta-se apenas com apoio, tendendo a escorregar sobre o assento, pois apresenta movimentos de extensão do corpo. Apresenta dificuldades para manusear os objetos e não recusa auxilio, contudo, é bastante ativo durante as atividades. 
A gravidez de V. não foi planejada, mas foi bem aceita pela mãe. A gestação foi tranqüila; no entanto, a mãe teve problemas durante o parto, pois foi forçado um parto normal, apesar de não ter "passagem” (sic). A descoberta da deficiência do filho foi um choque para a mãe, que tentou manter a calma e buscar tratamento para ele. O seu desenvolvimento foi lento e doloroso, mas a mãe relata que considera como uma grande vitória cada detalhe que a criança conquista. A criança realiza, há bastante tempo, tratamento em fisioterapia e terapia ocupacional (na APAE Vitória); além disso, realiza terapia ocupacional (na FAESA), fonoaudiologia e ajuda pedagógica (na escola).

Seus pais concluíram o ensino fundamental e V. freqüenta a $3^{\text {a }}$ série de uma escola municipal, em classe comum com acompanhamento de estagiária. V. mora com a mãe e o padrasto em uma casa de seis cômodos, tendo o seu próprio quarto. Relaciona-se bem com o padrasto, que convive com ele há quatro anos, gosta de brincar com ele e se considera seu pai. Sua mãe está grávida de uma menina e V. parece estar feliz com a chegada da irmã. A mãe não relata se a criança mantém contato com o pai biológico. A criança participa de todas as atividades da família. A mãe se recusa a realizar algo que exclua a criança. V. acompanha sua mãe ao supermercado, à igreja, à casa de coleguinhas, da avó e a outros lugares. A mãe relata que a família trata a criança normalmente.

V. gosta de brincar com bichos de brinquedo, com bola, bolinhas de gude, baldinhos, entre outros. Também gosta de rabiscar, assistir a DVD e ver figuras em livros. Gosta que contem histórias para ele. Tem um cachorro, do qual gosta bastante. Segundo as observações da mãe, V. fica bastante tempo com um mesmo brinquedo, inventa novas formas de usar os objetos e usa a imaginação. Aprecia brincar com bonecos como se fossem lutadores. Gosta muito de assistir à televisão. A brincadeira preferida é com bola; prefere ser o goleiro. Não gosta de brincar com carrinhos. Brinca sozinho, com os pais ou com outras crianças, mas prefere brincar com poucas 
pessoas. Durante a semana, a criança freqüenta a APAE, no período da manhã, e vai à escola ou aos tratamentos, à tarde. Nestes dias, brinca na APAE, com os amigos da escola ou com a mãe (à noite). Nos finais de semana, brinca o dia inteiro.

Desde o início da pesquisa, apesar de demonstrar dúvidas nos momentos da escolha dos brinquedos, a criança terminava sempre por optar pelos mesmos brinquedos: pescaria, carimbos e massinha. As brincadeiras que foram oferecidas à criança, bem como as brincadeiras por ela escolhidas são apresentadas na Tabela 6.17.

Tabela 6.17 - Sujeito V.: brincadeiras oferecidas e brincadeiras escolhidas.

\begin{tabular}{|l|c|c|}
\hline Brincadeiras & Oferecidas & Escolhidas \\
\hline Pescaria & 10 & 4 \\
\hline Bolinhas coloridas & 1 & - \\
\hline Carimbos & 7 & 4 \\
\hline Zoológico & 5 & - \\
\hline Rolos para derrubar & 2 & - \\
\hline Massinha & 6 & 2 \\
\hline Monte Castelo & 1 & - \\
\hline Vira Lata & 2 & - \\
\hline Quadro imantado & 1 & - \\
\hline Corrida de carrinhos & 1 & - \\
\hline Fantoches e livros & 1 & - \\
\hline
\end{tabular}

A criança demonstrou grande interesse pela pescaria, realizando esta brincadeira em quatro atendimentos, sendo três atendimentos consecutivos. No início desta brincadeira, V. sempre escolhia, apontando ou indicando com o olhar, em qual bacia gostaria de colocar a água: na “grande”, na "média” ou na "pequena”. As demais bacias eram utilizadas para colocar os peixes pescados por cada participante, sendo cada uma colocada de um "lado" da mesa. Ele escolhia qual varinha gostaria de usar, com cabo “curto” ou "comprido”. Combinavam que, "antes”, deveriam arrumar os peixes “dentro” da bacia com água para, “depois”, começarem a pescar. Era comentado que havia “muitos” peixes. O padrasto e/ou a estagiária sempre participavam como adversários, mas a pesquisadora auxiliava a criança a manusear a varinha e a retirar os peixes do 
anzol. Apesar da ajuda, a pesquisadora também deixava que a criança direcionasse a varinha, quando, por exemplo, queria derrubar o peixe da varinha do adversário. Em muitos momentos, parecia se preocupar mais em atrapalhar o adversário do que em pescar. Ao pescarem, era comentado se pegavam um peixe pequeno, médio ou grande. A pesquisadora comentava quando os peixes estavam "quase” acabando; quando todos os peixes já tinham sido pescados, a pesquisadora comentava que a bacia estava "vazia”, sem peixes. Quando o peixe caía para "fora” da bacia, era pedido para que V. o colocasse dentro dela. Após pescarem, os peixes eram colocados sobre a mesa e eram contados, para que fosse determinado quem havia pescado "mais" e quem havia pescado "menos” peixes. Nos primeiros atendimentos, a criança parecia não compreender bem a seqüência da brincadeira, tentando devolver seus peixes para a bacia antes que todos fossem pescados ou misturando os seus peixes com os do adversário, no momento da contagem. Com o passar dos atendimentos, a criança parecia compreender melhor que a brincadeira possui um começo, um meio e um fim, além de se interessar mais pelo momento da contagem e da comparação das quantidades, quando era determinado quem havia pescado mais e menos.

Em dois atendimentos, V. escolheu brincar com a massinha, preferindo fazer bichinhos com as forminhas. A pesquisadora lhe explicou que, “antes”, era necessário preparar a massa para, “depois”, fazer os bichinhos. Visto que a massa era muito “grande”, a criança foi ajudada a cortála ao “meio”, pela “metade”. A criança era ajudada a amassar e a fazer os bichos, sendo nomeado se estes eram "grandes" ou "pequenos"; depois, ela era solicitada a empurrar, com um dedo, a figura para fora da forminha. V. indicava de que "lado" colocaria cada figura, do "lado direito" ou "esquerdo"; as figuras de um lado seriam para a pesquisadora e, as do outro lado, para a estagiária. Para separar as figuras de cada uma, foi colocado um pedaço de fita crepe “entre” elas. Quando a pesquisadora ou a estagiária reclamava que tinha “menos" figuras, pois do outro lado 
havia “mais”, a criança fazia mais figuras para o lado que possuía menos. Por fim, a criança quis fazer batatas; a pesquisadora sugeriu fazê-las de diferentes tamanhos, “pequenas”, “médias” e "grandes".

Nos quatro últimos atendimentos, V. brincou com os carimbos. Em dois destes dias, a criança carimbou bichos do mar. A pesquisadora lhe mostrou que, “antes”, ele deveria molhar o carimbo na tinta para, “depois”, carimbar o papel. Foi comentado que a criança havia carimbado “muitos” tubarões, havendo “mais” tubarões e “menos” peixes. Visto que estes eram "pequenos”, foram feitos também tubarões "grandes” e "médios”. A criança foi ajudada a recortar os peixes; em seguida, escolheu em qual bacia os colocaria para que fossem pescados. Pescaram com a mãozinha de silicone (utilizada como varinha, visto que gruda no papel), enquanto comentavam qual era o tamanho dos peixes pescados. Comparavam quem havia pescado mais e menos peixes e tubarões. Em alguns momentos, também brincavam de acertar o adversário com a mãozinha, como se fossem pescá-lo. Nos outros dois atendimentos, a criança escolheu brincar com os carimbos dos bichos da terra. Todos os carimbos estavam misturados, contudo a criança soube separar adequadamente os carimbos dos bichos da terra dos carimbos dos bichos do mar, colocando cada tipo de um "lado" da mesa. Todos ajudaram a carimbar os bichos. A pesquisadora e a criança carimbaram bois “em volta” dos demais bichos, visando protegê-los, visto que o padrasto dizia que seu bode comeria os patos da criança. A estagiária também fez sapos "grandes” e "médios”, para que fossem pegos com a mãozinha. A dinâmica da brincadeira era a mesma da anterior, mas, ao invés de serem pescados, os bichos eram caçados com a mãozinha de silicone. Por fim, a pesquisadora sempre carimbava um bicho na mão "direita” e o outro na mão “esquerda” da criança.

No início da pesquisa, a criança mostrava resistência para guardar os brinquedos, por querer brincar mais ou por querer levar o brinquedo para casa. Nestes momentos, a pesquisadora insistia 
que era necessário guardar, mas que os brinquedos seriam colocados dentro da mala, para que ele pudesse brincar novamente na semana seguinte. Aos poucos V. foi aceitando melhor o momento de guardar os brinquedos.

Em alguns atendimentos, V. não aceitava que seria a vez de seu padrasto brincar, não querendo passar-lhe o brinquedo ou atrapalhando-o a brincar. Conforme a pesquisadora foi explicando a ele que deveria deixar seu adversário brincar e que não era justo atrapalhá-lo jogar, V. passou a aceitar a vez dele e a aguardar a sua vez de brincar. Neste mesmo período, a criança passou a compreender e respeitar a seqüência da brincadeira. Antes, por exemplo, na brincadeira da pescaria, a criança tentava devolver os peixes para a bacia antes de pescarem todos e, no momento da contagem dos pontos, tentava misturar os peixes dos jogadores e não prestava atenção à contagem, que visava determinar quem havia pescado mais e menos peixes.

V. ria das falas incongruentes ou dos acontecimentos engraçados (quando era feita alguma piadinha, ou quando alguém derrubava algo ou quase caía), mostrando-se atento ao seu ambiente e demonstrando compreender tudo o que era falado.

Devido à dificuldade que a criança apresenta na fala, quando a pesquisadora queria oferecer-lhe algo, apontava e nomeava as opções; então a criança escolhia, olhando para o objeto escolhido ou levando a mão em sua direção. No decorrer da pesquisa, a pesquisadora passou a conhecer melhor a criança e a estabelecer, com ela, uma comunicação mais efetiva. Assim, V. fazia alguns gestos e a pesquisadora nomeava o que este queria, aguardando que ele confirmasse, por meio de um sorriso, se a interpretação para o seu gesto era adequada.

Além dos movimentos involuntários, a criança também apresentava espasmos extensores, principalmente quando estava muito interessada em uma atividade, o que a fazia escorregar do assento, tendendo a cair do mesmo. Então, durante as sessões, a criança era posicionada sentada em uma cadeirinha, frente à mesinha, com um antiderrapante sobre o assento, uma calça de 
posicionamento (almofada feita com uma calça jeans recheada de retalhos, o que a deixava pesada) ao redor de sua cintura e um rolinho de espuma (encapado com tecido) entre a criança e a mesa, visando aumentar sua estabilidade.

A pesquisadora auxiliava a criança a realizar as atividades, contudo permitia que V. tentasse controlar seus movimentos. Seguia a iniciativa dele quando este escolhia fazer algo com o brinquedo ou quando tentava realizar algo sozinho. Nestes momentos, diminuía o grau de assistência, permitindo que ele realizasse a maior parte do movimento sem ajuda.

A pesquisadora permitia que $\mathrm{V}$. levasse os peixes ou bichos carimbados para brincar em casa. Sua mãe, então, confeccionou uma varinha de pescar com uma vara, um barbante e um pedaço de fita adesiva (durex ou fita crepe). Assim, ele repetia em casa a brincadeira aprendida na terapia, grudando os peixes de papel na fita adesiva.

$\mathrm{Na}$ brincadeira com os carimbos, ao solicitar que a criança agrupasse os bichos pelos tipos (bichos do mar e bichos da terra), a pesquisadora estava estimulando a classificação dos mesmos. V. necessitou de pouca ajuda, realizando a tarefa com sucesso.

V. compareceu a 12 das 16 sessões oferecidas. Visto que a primeira e a última sessão eram destinadas à realização dos testes, em apenas dez sessões foram realizadas as brincadeiras que envolviam os conceitos da pesquisa. Além das quatro faltas, a criança chegou atrasada a quatro dos atendimentos, o que diminuiu ainda mais o tempo despendido nas brincadeiras.

A Tabela 6.18 apresenta o número de sessões nas quais foram trabalhados os conceitos avaliados por meio do teste de conceitos. 
Tabela 6.18 - Sujeito V.: número e porcentagem de sessões em que os conceitos foram trabalhados nas brincadeiras.

\begin{tabular}{|l|c|c|}
\hline Conceito & No. de sessões & \% de sessões \\
\hline Menos & 10 & 100 \\
\hline Tamanho médio & 10 & 100 \\
\hline Depois & 8 & 80 \\
\hline Muitos & 3 & 30 \\
\hline Lado direito & 3 & 30 \\
\hline Em volta & 2 & 20 \\
\hline Metade & 2 & 20 \\
\hline Quase & 1 & 10 \\
\hline Entre & 1 & 10 \\
\hline Centro & - & - \\
\hline Cedo & - & - \\
\hline Nunca & - & - \\
\hline Logo & - & - \\
\hline Debaixo & - & - \\
\hline Agora & - & - \\
\hline
\end{tabular}

Como apresentado na Tabela 6.18, os conceitos "tamanho médio" e "menos” foram trabalhados em todos os atendimentos. Em seguida, o conceito mais trabalhado foi o de "depois" (80\% dos atendimentos), seguido pelos conceitos de "muitos" e "lado direito" (30\%). Além destes, outros conceitos também foram trabalhados no decorrer das brincadeiras, sendo estes apresentados na Tabela 6.19.

Tabela 6.19 - Sujeito V.: conceitos trabalhados nas brincadeiras, mas não avaliados pelo Teste de Boehm.

\begin{tabular}{|l|c|c|}
\hline Conceito & No. de sessões & \% de sessões \\
\hline Pequeno & 10 & 100 \\
\hline Grande & 10 & 100 \\
\hline Mais & 10 & 100 \\
\hline Antes & 8 & 80 \\
\hline Lado & 6 & 60 \\
\hline Dentro & 3 & 30 \\
\hline Lado esquerdo & 3 & 30 \\
\hline Fora & 1 & 10 \\
\hline Vazio & 1 & 10 \\
\hline Comprido & 1 & 10 \\
\hline Curto & 1 & 10 \\
\hline Meio & 1 & 10 \\
\hline Primeiro & 1 & 10 \\
\hline
\end{tabular}


Dentre estes conceitos, alguns foram utilizados em todas as sessões, sendo estes os conceitos de "pequeno" e "grande”, por serem relacionados ao conceito de "tamanho médio", e “mais”, por ser tomado em oposição ao conceito de “menos”. Em seguida, o conceito de "antes” (80\%) foi o mais utilizado, sendo este oposto ao conceito de “depois”, seguindo-se o conceito de “lado" (60\%).

Na brincadeira da pescaria, ao escolherem nomes para os peixes, foi dito que a pesquisadora e o padrasto da criança eram os peixes pequenos, enquanto V. e a estagiária seriam peixes grandes. Ele riu e apontou para dois peixes grandes e, em seguida, para seu padrasto e para a pesquisadora. Esta perguntou se eles eram peixes grandes e a criança concordou. Isso mostra que a criança compreendia a diferença entre os tamanhos e que, nesta brincadeira, quem fosse um peixe pequeno estaria em desvantagem.

Na pescaria com peixes carimbados, a criança tentava pegar os peixes maiores, sorrindo quando conseguia pescar um peixe médio ou grande, o que mostra que compreendia que era melhor pescar estes do que pescar peixes pequenos. Também se alegrava quando conseguia pescar mais de um peixe, mostrando-se atenta à variação da quantidade de peixes pescados.

Em um dos últimos atendimentos, V. soube identificar um objeto de tamanho grande. Em um outro dia, na pescaria com peixes carimbados, a pesquisadora perguntou para ele quem havia pescado mais peixes e ele respondeu adequadamente; em seguida, perguntou quem havia pescado menos e ele acertou novamente. Após jogarem outra partida, a pesquisadora questionou novamente, mas, desta vez, perguntando primeiro quem havia pescado menos, o que fez com que a criança errasse. Este fato mostra que os conceitos “mais” e “menos" estavam em fase de aprendizagem, não sendo completamente dominados pela criança. Na sessão seguinte, a criança soube indicar quem havia pescado mais e, em seguida, quem havia pescado menos. Desta forma, é possível supor que V. conhecia melhor o conceito de “mais", pois acertava quando a pergunta 
começava por este. A hipótese de que estes conceitos estavam em fase de aprendizagem pôde ser reforçada pelas respostas da criança aos testes. No pré-teste, ao ser questionada sobre o prato que possuía menos doces, a criança apontou para o prato com mais doces (10 unidades). No pós-teste, ela errou novamente, não apontando para o prato com um doce, contudo, apontou para o prato com três doces, fazendo-nos pensar que já percebia que o prato com 10 unidades possuía mais e não menos doces.

Os resultados apresentados pela criança, tanto no pré-teste quanto no pós-teste, estão dispostos na Tabela 6.20.

Tabela 6.20 - Sujeito V.: resultados do pré e pós-teste, no Teste de Boehm.

\begin{tabular}{|c|c|c|}
\hline Conceitos & Pré-teste & Pós-teste \\
\hline 1 - Inst. Sapato & $\mathrm{A}$ & $\mathrm{A}$ \\
\hline 2 - Inst. Banana & A & A \\
\hline 3 - Inst. Carro & $\mathrm{A}$ & A \\
\hline 4 - Inst. Mesa & $\bar{A}$ & $\bar{A}$ \\
\hline 5 - Inst. Copo & $\mathrm{A}$ & A \\
\hline 6 - Inst. Cachorro & A & A \\
\hline Total - instrução & 6 & 6 \\
\hline 1 - Depois & $E_{c}$ & A \\
\hline 2 - Centro & A & $E$ \\
\hline 3-Quase & A & A \\
\hline 4-Em volta & $\mathrm{E}_{\mathrm{c}}$ & A \\
\hline $5-$ Cedo & $\mathrm{A}$ & $\mathrm{A}$ \\
\hline 6- Nunca & $E_{c}$ & $\mathrm{E}_{\mathrm{a}}$ \\
\hline 7 - Metade & $E_{c}$ & $\mathrm{E}_{\mathrm{c}}$ \\
\hline 8 - Lado direito & $E_{b}$ & $E_{b}$ \\
\hline 9 - Tam. Médio & $\mathrm{E}_{\mathrm{b}}$ & $E_{b}$ \\
\hline $10-$ Menos & $E_{b}$ & $E_{a}$ \\
\hline 11 - Entre & $E_{c}$ & $\mathrm{E}$ \\
\hline $12-$ Logo & $\mathrm{A}$ & $\mathrm{A}$ \\
\hline 13 - Debaixo & A & A \\
\hline 14 - Muitas & A & A \\
\hline 15 - Agora & $\mathrm{A}$ & $\mathrm{A}$ \\
\hline Total - acertos & 7 & 8 \\
\hline
\end{tabular}


No pré-teste, V. respondia às questões apontando com o dedo. Às vezes, apontava mais de uma opção, ou pelo movimento incoordenado ou porque queria mostrar algo; então, a pesquisadora pedia para que ele escolhesse apenas um desenho. V. acertou todos os itens de instrução, mas errou algumas questões do teste de conceitos. Apesar de utilizar a mão esquerda para apontar, a criança apontou muitas vezes para o desenho que estava no lado direito, o que indica que o lado utilizado não interferiu nas respostas da criança. Na questão que se refere ao conceito "nunca”, V. apontou para a pizza, mas parecia estar mostrando que ele gosta de pizza. Ao responder à questão sobre o conceito “menos", V. mostrou o prato que trazia mais doces e também parecia estar mostrando que gosta de doces.

No pós-teste, em alguns momentos, V. respondia muito rapidamente, pois estava interessado em entregar a cartela a seu tio; então, a pesquisadora pedia para que, antes de responder, ele olhasse para todos os desenhos. Quando a criança apontava para mais de uma opção, a pesquisadora pedia para que ela olhasse para todas as opções e escolhesse apenas uma. Na questão referente ao conceito de "entre”, V. mostrou os três desenhos, parecendo não se decidir; então, a pesquisadora considerou como erro.

V. acertou os conceitos de "depois" (utilizado em 80\% dos atendimentos) e "em volta" (20\%), que havia errado no pré-teste. Contudo, errou o conceito de “centro”, que havia acertado no pré-teste e que não foi trabalhado em nenhuma das brincadeiras realizadas pela criança. Na questão referente ao conceito de "menos”, V. havia indicado o prato com mais doces, no préteste. Já no pós-teste, indicou o prato com três doces, ao invés de mostrar o prato com um ou com vários doces. Desta forma, assim como mencionado anteriormente, este resultado pode indicar que este conceito, trabalhado em 100\% dos atendimentos, estava sendo aprendido pela criança, não sendo ainda totalmente dominado por ela. 


\subsection{6 - E. o cozinheiro}

E., sexo masculino, 10 anos de idade, apresenta seqüelas de paralisia cerebral diparética espástica. Não anda, mas, em ambientes internos, locomove-se com independência em sua cadeira de rodas. Necessita de ajuda para as transferências, mas senta-se em cadeira comum, mantendo bom equilíbrio nesta posição. Apresenta forte espasticidade nos membros inferiores, contudo apresenta leve comprometimento dos membros superiores, não apresentando alterações aparentes na coordenação motora fina das mãos. Fala com dificuldades, mas estabelece, com o interlocutor, alguns sons e gestos significativos.

A gestação de E. foi tranqüila, tendo apenas ocorrido um parto demorado. A criança apresentou atraso no desenvolvimento, sendo a paralisia cerebral constatada apenas aos seis meses de vida. A criança realiza atendimentos de fisioterapia na EMESCAM e de fonoaudiologia na FAESA (ES).

Os pais de E. cursaram parte do ensino fundamental (até a $6^{\mathrm{a}}$ série), e a criança freqüenta a $3^{\text {a }}$ série de uma escola comum. Mora com os pais, em uma casa espaçosa e com quintal, no qual a criança gosta de brincar. Ela passeia com a família, vai à igreja e à praia. Segundo a mãe, a relação da criança com os parentes é boa, pois é uma criança muito alegre e que cativa as pessoas.

E. gosta de brincar com bola, carrinho, brinquedos de montar e de colar papel picado. As brincadeiras preferidas são as que envolvem terra. De acordo com sua mãe, E. não evita nenhum tipo de brincadeira. Durante a semana, brinca de manhã, com os primos, e um pouco à noite (às vezes, com a mãe). Nestes dias, quando não está na escola ou nos tratamentos, permanece na casa da tia, visto que sua mãe trabalha. Nos finais de semana, brinca no período da manhã, geralmente sozinha. A tia da criança relata que esta gosta muito de assistir à televisão e a desenhos no DVD. 
No primeiro atendimento, assim que entrou na sala com E., sua tia relatou que não é sua mãe, mas apenas cuida dele, visto que a mãe trabalha. Ela relatou estar muito cansada, por levá-lo aos atendimentos de fisioterapia e fonoaudiologia e por ficar subindo e descendo as escadas de seu prédio com a criança no colo. Apesar de a tia querer parar de cuidar de E., sua mãe tem dificuldades em achar alguém que cuide direito dele. Ela disse que, às vezes, o coloca de castigo, pois ele é “danado” (sic). Disse também que gostaria que sua mãe participasse mais, pois tudo é ela quem precisa resolver.

Durante os atendimentos, E. demonstrou grande interesse em brincar com a massinha (escolhida nove vezes), sendo que, em três sessões, associou a esta brincadeira o uso do quadro imantado com figuras. Além das brincadeiras com massinha, ele brincou duas vezes com o Monte Castelo e duas vezes com os fantoches e os livros, acrescentando os dedoches em alguns destes atendimentos. A Tabela 6.21 mostra as brincadeiras que foram oferecidas à criança, bem como as escolhas feitas por ela.

Tabela 6.21 - Sujeito E.: brincadeiras oferecidas e brincadeiras escolhidas.

\begin{tabular}{|l|c|c|}
\hline Brincadeiras & Oferecidas & Escolhidas \\
\hline Bolinhas & 1 & - \\
\hline Carimbos & 4 & - \\
\hline Massinha & 13 & 9 \\
\hline Rolos para derrubar & 1 & - \\
\hline Pescaria & 3 & - \\
\hline Zoológico & 6 & - \\
\hline Bichos de massinha & 1 & - \\
\hline Monte Castelo & 7 & 2 \\
\hline Dedoches & 3 & 3 \\
\hline Quadro imantado & 3 & 3 \\
\hline Carrinhos & 2 & - \\
\hline Fantoches e livros & 3 & 2 \\
\hline Vira Lata & 1 & - \\
\hline
\end{tabular}


No primeiro dia no qual a criança brincou com a massinha, ela apresentou um comportamento exploratório, apenas amassando e furando a massa, aparentemente sem realizar uma atividade simbólica ou com uma seqüência lógica. Além disso, recusava as intervenções da pesquisadora. Nos demais atendimentos, aos poucos, passou a aceitar a intervenção da pesquisadora e da estagiária e a participar de brincadeiras simbólicas com a massinha.

Por exemplo, no segundo dia, E. pediu para utilizar as bacias, então a pesquisadora pediu que ele escolhesse qual queria utilizar (“pequena”, "média” ou "grande”) e quais seriam para as demais participantes. A criança começou a repartir a massa com a faquinha e a colocar um pedaço em cada bacia. Em alguns momentos, a pesquisadora indicava que havia "mais” massinha em uma bacia e "menos” em outra, pedindo para que a criança colocasse mais massinha nesta. A pesquisadora fez "muitas" bolinhas com a sua massa. E. enrolou a massa, a pesquisadora comentou que parecia um pão, e a criança riu. A estagiária também solicitou um pão, e a criança o fez. Começaram, então, a brincar de fazer pães, biscoitos e bolos. E. fez gestos, parecendo pedir por algo. A pesquisadora perguntou se ele queria um forno para colocar os pães, e ele concordou. Ela, então, colocou o banquinho sobre a mesa, que passou a ser usado como forno para colocar os pães e os biscoitos. A pesquisadora comentou que, "antes”, deveriam fazer o biscoito para, “depois”, colocá-lo no forno. Após fazerem os pães, repartiam e davam pedaços uns para os outros. Às vezes, a pesquisadora comentava que estava cortando o pão pela “metade”. Ao colocarem a bacia no forno, a pesquisadora olhava para o relógio e dizia que a comida estava “quase” pronta. Depois de um pequeno intervalo de tempo dizia que "agora” estaria pronto. A criança ria e pedia sempre para verificar o tempo, indicando para que a pesquisadora olhasse no relógio.

Em um atendimento, a criança se interessou pelo quadro imantado, então, visto que ela havia escolhido brincar também com a massinha, a pesquisadora sugeriu que brincassem de 
restaurante, fazendo comida de massinha para servirem aos clientes (as figuras de pessoas que a criança havia colado no quadro imantado). Nesta brincadeira, E. era o chefe de cozinha, de modo que a pesquisadora e a estagiária eram suas auxiliares. A criança, então, ordenava o que elas deveriam fazer para servir aos clientes (a criança aprovava ou não os pratos sugeridos, apontando para quem deveria fazer cada um). Quando a pesquisadora ou a estagiária não obedeciam às suas ordens, a criança levava a mão em direção à própria testa, como quem presta continência; então, elas também prestavam continência e diziam “sim, senhor”, executando suas ordens. Em alguns momentos, a estagiária ou a pesquisadora também assumiam a posição de chefe, sendo suas ordens obedecidas por todos os demais participantes. Esta brincadeira foi repetida em outros atendimentos.

Em uma outra sessão, a criança escolheu fazer bichos de massinha, que seriam vendidos aos clientes do petshop (figuras de pessoas coladas no quadro imantado). As figuras do quadro imantado foram dispostas sobre a mesa, sendo delimitados, com fita crepe, os espaços nos quais eram colocados os bichos de cada cliente. Comentavam sobre o tamanho das figuras e sobre a quantidade de bichos pertencente a cada personagem. Ao final das brincadeiras com massinha, E. sempre pedia para fazer um bolo de aniversário, para cantarem parabéns para os aniversariantes ou para fazerem o casamento das figuras de pessoas utilizadas no quadro imantado, as quais ele nomeava de papai e mamãe.

Em dois outros atendimentos, E. brincou com o Monte Castelo. Ao montar as casas, era permitido que ele experimentasse para testar as peças que encaixavam ou não, sendo salientado que algumas eram “quadradas” e outras “redondas”. Foram feitos prédios "pequenos”, “médios” e "grandes”. Enquanto colocavam os dedoches da Turma da Mônica “dentro" de cada casa e de cada prédio, a pesquisadora comentava se os bonecos eram colocados "em cima” ou "embaixo" (nos diferentes andares dos prédios). Quando a criança fazia apenas casas, a pesquisadora 
comentava que eram “muitas”. Quando ele não colocava o chão ou o teto da casa, a pesquisadora comentava que "nunca" havia visto uma casa sem chão e/ou sem teto, então E. ria. Foi colocado um pedaço de fita crepe no "meio" da mesa, que seria a "rua”. Então, a pesquisadora mostrou que havia "mais" casas de um "lado" e "menos” casas do outro lado. Em um momento, mostrou que havia uma igreja, então a criança pediu para fazerem o casamento de dois bonecos. E. dizia que se casaria com a pesquisadora, enquanto seu primo se casaria com a estagiária. No momento de guardar, a pesquisadora pedia para que colocasse as peças das casas em uma caixa e os dedoches em outra caixa, mas a criança precisava de auxílio para não confundir os locais corretos para guardar os brinquedos.

Nos dois últimos atendimentos, E. escolheu brincar com os fantoches e os livrinhos. Inicialmente, ele ficou dividindo os livros entre os participantes, contudo, distribuía, recolhia e distribuía novamente. Então, a pesquisadora disse que já estava dividido, sendo que, "agora”, estaria na hora de contarem as histórias. Foi decidido quem contaria a "primeira” história e quem contaria “depois”. Na sua vez, cada participante escolhia um livro e pegava o fantoche correspondente para contar a história. A criança ria e também colocava o fantoche em sua mão. Em um desenho, ela soube identificar a vaca “pequena” e a vaca "grande”. E. também mostrou os bichos de tamanhos diferentes, dizendo que eram a mamãe, o papai e o filhinho. A pesquisadora comentou que havia "muitos” bichos na fazenda. Em um momento, ela mostrou o desenho do ovo, com o pintinho dentro, então E. mostrou a barriga e disse “mamãe”. A pesquisadora comentou que ele havia nascido da barriga de sua mamãe, e ele concordou. Quando a criança queria trocar de livro antes de terminar a história, a pesquisadora dizia que estava "quase" acabando, sendo necessário terminar uma história para começar outra. Contudo, E. apresentava dificuldades em manter-se atento até o final da história. Após terminarem, ele pegou o livro da Branca de Neve; todos o folhearam e comentaram sobre os desenhos. A criança apontou para a 
bruxa, apontou para si e deu uma risada, imitando a risada da bruxa, e todos riram. Comentaram que havia “muitos” anões.

No outro atendimento, ao invés de utilizarem apenas os livrinhos, também utilizaram os gibis e os dedoches da Turma da Mônica. A pesquisadora fazia perguntas sobre os desenhos, tais como “Quem está comendo agora?” ou “Quem está dormindo agora?” e a criança apontava corretamente. Por fim, E. escolheu ver o livro da Branca de Neve e começou a folhear de trás para frente. Então, a pesquisadora mostrou que a história começava do outro lado do livro e ajudou E. a nomear o que se passava nas figuras. Fizeram a gargalhada da bruxa e foram nomeando qual dedoche seria qual personagem. Colocaram todos enfileirados e cantaram a música dos anões. Encenaram a história utilizando os dedoches, colocados sobre a mesa. Por fim, fizeram o casamento da Branca de Neve com o príncipe.

Apesar de sua mãe ter respondido, no questionário, que a criança se relaciona bem com as pessoas, por ser carinhoso e alegre, isso não foi observado nos primeiros dias de atendimentos, nos quais E. se mostrava agressivo e não respeitava os limites impostos pelas terapeutas. A tia, além de ter relatado que ele havia agredido a fonoaudióloga, também demonstrava sua insatisfação quanto ao comportamento da criança, relacionando-se de maneira fria com a mesma. No terceiro atendimento, a pesquisadora conversou com a tia sobre a necessidade de valorizar os bons comportamentos da criança, ao invés de enfatizar apenas seus maus comportamentos. Esta atitude também foi adotada pela pesquisadora, que, durante os atendimentos, comentava com a criança quando esta fazia algo adequadamente. Também relatava à tia, na presença da criança, o que esta havia feito de adequado durante a terapia. No primeiro momento em que isto aconteceu, a tia se mostrou espantada com o fato da criança ter se comportado de maneira correta. O vínculo estabelecido com a criança durante as brincadeiras, nas quais há uma modificação nas relações de poder, também possibilitou que a criança modificasse seu comportamento perante as terapeutas. 
Desta forma, com o passar das sessões, a criança passou a respeitar os limites impostos e a se relacionar de maneira carinhosa com as terapeutas, sendo esta relação de carinho também estendida aos contatos da criança com sua tia, que passou a demonstrar mais o seu afeto por ela.

No início da pesquisa, enquanto a criança ainda apresentava comportamentos inadequados, a pesquisadora tentava conciliar a brincadeira livre com a imposição de limites à criança. Ou seja, ela poderia brincar da maneira desejada, contudo, deveria respeitar as demais participantes, esperando sua vez de usar os objetos e não sendo permitido que atrapalhasse o que elas estavam fazendo. Também não era permitido que a criança desrespeitasse a pesquisadora ou a estagiária. Quando necessário, a pesquisadora chamava a atenção da criança; contudo, quando a criança apresentava um comportamento adequado, este era valorizado e enfatizado.

Nestes primeiros atendimentos, a criança se recusava a ajudar a guardar os brinquedos, mas a pesquisadora insistia, dizendo que todos que brincaram precisavam ajudar a guardar. Aos poucos, a criança passou a colaborar para a arrumação dos brinquedos, sem se queixar.

Ao brincar com a massinha pelas primeiras vezes, a criança apresentou um comportamento exploratório, apenas apertando, furando e cortando a massa. Não aceitava a intervenção da pesquisadora, recusando sua ajuda ou suas sugestões. Esta permitia que a criança brincasse como desejava, contudo, tentava despertar seu interesse para outras maneiras de brincar, além de tentar incluir um caráter simbólico em sua brincadeira. Sempre que a criança parecia apenas explorar a massa, sem atribuir-lhe sentido, a pesquisadora perguntava se a criança estaria fazendo um determinado objeto e aguardava a resposta da criança. Com o decorrer dos atendimentos, a criança começou a participar da brincadeira conjunta, engajando-se nas atividades simbólicas, parecendo compreender a seqüência das mesmas. E. passou a aceitar os significados atribuídos às figuras de massinha, agindo de acordo com o significado escolhido, adicionando, inclusive, 
novos elementos à brincadeira (como no dia em que procurou por algo para usar como um “forno”).

Em um outro atendimento, ao utilizar pela primeira vez os utensílios diferentes para brincar com a massinha, E. pareceu voltar ao comportamento exploratório. A pesquisadora tentava incluir algo simbólico na brincadeira, ele concordava, brincava junto por pouco tempo, mas voltava a explorar o material. Portanto, ele não participou de uma atividade simbólica com começo, meio e fim, como já havia feito em outros atendimentos. Na semana seguinte, visto que E. escolheu brincar novamente com a massinha, a pesquisadora sugeriu que brincassem de restaurante, visando estimular que ele participasse de uma atividade simbólica desde o início do atendimento, evitando a simples exploração dos objetos.

A brincadeira de restaurante, na qual a criança era o chefe de cozinha e a pesquisadora e a estagiária eram suas ajudantes, possibilitou uma inversão nas relações de poder. Assim, ele teve a oportunidade de estar à frente, tomando decisões e exigindo que suas ordens fossem obedecidas, de modo que pôde vivenciar relações distintas das comumente vivenciadas em seu dia a dia, nas quais a criança é quem deve obedecer aos seus pais, a sua tia ou as suas terapeutas.

Quando E. fazia gestos, a pesquisadora tentava nomear o que estava pedindo. Quando ele mostrava ou pedia algo, a pesquisadora aceitava a sugestão, incluindo aquele objeto na brincadeira que já estava sendo realizada. Contudo, a pesquisadora não permitia que ele mudasse de brincadeira, dizendo que poderia brincar com o outro brinquedo na semana seguinte.

Os três participantes (criança, pesquisadora e estagiária), na dinâmica dos atendimentos, foram estabelecendo juntos alguns gestos para a comunicação. Assim, quando E. fazia um gesto, elas percebiam o que ele queria dizer e perguntavam se era aquilo mesmo; em seguida, ele concordava ou não. Quando concordavam quanto ao sentido de algum gesto, este passava a fazer parte de um código de comunicação entre eles. Deste modo, com o passar do tempo, foi possível 
o estabelecimento de diálogos entre os participantes, ainda que a criança apresentasse dificuldades quanto à fala.

Em uma sessão, a pesquisadora pediu para que E. colocasse os bonecos em uma caixa e as casas, em outra. Desta maneira, foi possível observar o desempenho dele em atividades de classificação. Ele precisou de ajuda para guardar estes brinquedos da maneira solicitada, demonstrando dificuldade quanto à classificação dos mesmos.

Visto que E. não mantinha a atenção por muito tempo, a pesquisadora e a estagiária combinaram não chamar sua atenção para outra atividade enquanto ele estivesse fazendo algo. Esta postura permitiu que a criança conseguisse manter-se por um tempo maior engajado em uma mesma brincadeira, participando de todas as etapas da mesma.

E. participou de 14 das 16 sessões oferecidas. Visto que os testes eram realizados nas sessões inicial e final, os conceitos da pesquisa foram trabalhados em apenas 12 atendimentos. A Tabela 6.22 apresenta o número de sessões nas quais estes conceitos foram trabalhados.

Tabela 6.22 - Sujeito E.: número e porcentagem de sessões em que os conceitos foram trabalhados nas brincadeiras.

\begin{tabular}{|l|c|c|}
\hline Conceito & No. de sessões & \% de sessões \\
\hline Muitos & 11 & 91,7 \\
\hline Tamanho médio & 9 & 75 \\
\hline Metade & 8 & 66,7 \\
\hline Depois & 8 & 66,7 \\
\hline Agora & 6 & 50 \\
\hline Quase & 5 & 41,7 \\
\hline Menos & 4 & 33,3 \\
\hline Nunca & 3 & 25 \\
\hline Debaixo & 1 & 8,3 \\
\hline Logo & - & - \\
\hline Entre & - & - \\
\hline Lado direito & - & - \\
\hline Cedo & - & - \\
\hline Em volta & - & - \\
\hline Centro & - & - \\
\hline
\end{tabular}


Como é possível observar, os conceitos mais trabalhados durante a pesquisa foram "muitos” (trabalhado em 91,7\% dos atendimentos), “tamanho médio" (75\%), “metade” e “depois" (66,7\%). Em seguida, os conceitos mais trabalhados foram "agora” (50\%), "quase” (41,7\%) e “menos” (33,3\%).

Além destes conceitos, outros também foram trabalhados no decorrer das brincadeiras, variando de acordo com as situações encontradas. Estes conceitos são apresentados na Tabela 6.23 .

Tabela 6.23 - Sujeito E.: conceitos trabalhados nas brincadeiras, mas não avaliados pelo Teste de Boehm.

\begin{tabular}{|l|c|c|}
\hline Conceito & No. de sessões & \% de sessões \\
\hline Grande & 11 & 91,7 \\
\hline Pequeno & 10 & 83,3 \\
\hline Antes & 5 & 41,7 \\
\hline Mais & 4 & 33,3 \\
\hline Dentro & 4 & 33,3 \\
\hline Meio & 3 & 25 \\
\hline Maior & 3 & 25 \\
\hline Lado & 3 & 25 \\
\hline Menor & 2 & 16,7 \\
\hline Em cima & 2 & 16,7 \\
\hline Primeiro (a) & 2 & 16,7 \\
\hline Redondo & 1 & 8,3 \\
\hline Quadrado & 1 & 8,3 \\
\hline
\end{tabular}

Os conceitos mais trabalhados durantes as brincadeiras foram "grande" (91,7\%) e “pequeno” (83,3\%), visto serem relacionados ao conceito de “tamanho médio”. Os demais foram utilizados em um número relativamente pequeno de brincadeiras.

Já nos últimos atendimentos, ao brincarem com os livrinhos de história e com os fantoches, E. indicou adequadamente as figuras de bichos pequenos e grandes; contudo, visto que estes conceitos não foram avaliados no início da pesquisa, não é possível afirmar que a criança os aprendeu no decorrer da mesma. Nestas brincadeiras com gibis e livrinhos, a pesquisadora 
também fazia perguntas como “quem está dormindo agora?” ou “quem está comendo agora?”, e a criança mostrava corretamente, sugerindo ter aprendido este conceito no decorrer das brincadeiras, visto que ela havia errado este conceito no pré-teste.

Como foi possível observar por meio do pré-teste, E. parecia realmente dominar o conceito de “depois”, apresentando, inclusive, um gesto que significava este conceito. Sempre que ele fazia círculos com as duas mãos paralelas, a pesquisadora perguntava se ele queria dizer "depois” e ele concordava.

A Tabela 6.24 apresenta os resultados obtidos pela criança tanto no pré-teste quanto no pósteste.

Tabela 6.24 - Sujeito E.: resultados do pré e pós-teste, no Teste de Boehm.

\begin{tabular}{|c|c|c|}
\hline Conceitos & Pré-teste & Pós-teste \\
\hline 1 - Inst. Sapato & $\mathrm{E}_{\mathrm{a}}$ & $\mathrm{A}$ \\
\hline 2 - Inst. Banana & A & A \\
\hline 3 - Inst. Carro & A & A \\
\hline 4 - Inst. Mesa & A & A \\
\hline 5 - Inst. Copo & $E_{c}$ & A \\
\hline 6 - Inst. Cachorro & $\mathrm{A}$ & A \\
\hline Total - instrução & 4 & 6 \\
\hline 1 - Depois & A & A \\
\hline 2 - Centro & A & A \\
\hline 3 -Quase & $E_{a}$ & $E_{a}$ \\
\hline $4-$ Em volta & $\mathrm{A}$ & $E_{c}$ \\
\hline 5 - Cedo & $\mathrm{A}$ & A \\
\hline 6-Nunca & $\mathrm{E}_{\mathrm{a}}$ & $E_{c}$ \\
\hline 7 - Metade & $E_{c}$ & $E_{b}$ \\
\hline 8 - Lado direito & $\mathrm{A}$ & $E_{a}$ \\
\hline 9 - Tam. Médio & $E_{b}$ & $E_{b}$ \\
\hline $10-$ Menos & $E_{b}$ & $\mathrm{~A}$ \\
\hline 11 - Entre & $\mathrm{A}$ & $E_{C}$ \\
\hline 12 - Logo & $\mathrm{A}$ & $\mathrm{A}$ \\
\hline 13 - Debaixo & $\mathrm{A}$ & $\mathrm{A}$ \\
\hline $14-$ Muitas & $E_{a}$ & $\mathrm{~A}$ \\
\hline 15 - Agora & $\mathrm{E}_{\mathrm{b}}$ & A \\
\hline Total - acertos & 8 & 8 \\
\hline
\end{tabular}


No pré-teste, E. acertou quatro das seis questões de instrução. Para responder, a criança apontava para os desenhos das cartelas. Durante a aplicação do teste, E. começou a ajudar a pesquisadora a guardar as cartelas já respondidas. Ele mostrou que teve brigadeiro na sua festa de aniversário (pois a cartela referente ao conceito “menos”, apresenta desenhos de brigadeiros). Quando a criança mostrava mais de uma opção, a pesquisadora salientava que ela precisava escolher uma apenas. Contudo, no decorrer do teste, ela passou a se comportar de maneira inadequada, não querendo responder ou mesmo tentando retirar a cartela da mão da pesquisadora, que precisou chamar sua atenção em alguns momentos. Assim, no final do teste, a criança já não demonstrava atenção às questões do mesmo.

No pós-teste, E. estava agitado e desatento, devido a uma festinha da qual havia participado, sendo necessário pedir para que prestasse atenção às perguntas e às respostas. E. acertou todos os conceitos do teste de instrução (no pré-teste, havia errado as questões referentes aos conceitos de “sapato” e “copo”). Errou as questões concernentes aos conceitos de "em volta”, "lado direito” e “entre”, que havia acertado no pré-teste e que, por este motivo, não foram trabalhados por meio das brincadeiras. Depois que a pesquisadora insistiu para que prestasse atenção, E. acertou algumas das questões que havia errado no pré-teste, sendo estas correspondentes aos conceitos de “muitas” (utilizado em 91,7\% dos atendimentos), “agora” (50\%) e “menos” (33,3\%).

Visto que a criança acertou três novos conceitos no pós-teste (“muitas”, “agora” e “menos”) e errou três conceitos que havia acertado no pré-teste, os resultados finais dos testes foram semelhantes, tendo a criança apresentado oito acertos tanto no pré-teste quanto no pós-teste. Deste modo, é possível pensar que os acertos do pré-teste referentes a estes três conceitos (“em volta”, "lado direito” e “entre”) tenham ocorrido por acaso, ou que estes erros no pós-teste tenham ocorrido devido à falta de atenção apresentada pela criança durante a execução do mesmo. Contudo, o fato de a criança ter acertado, no pós-teste, um conceito bastante trabalhado 
nas brincadeiras (“muitas”) e um outro conceito que foi avaliado durante uma brincadeira realizada no final da pesquisa (“agora”), parece indicar que a criança tenha realmente aprendido estes conceitos no decorrer da pesquisa.

\subsection{7 - L. mestre das formas}

L., sexo feminino, dez anos e dois meses de idade, apresenta seqüelas de paralisia cerebral tetraparética atetóide com componente espástico. Consegue sentar-se em banco ou cadeira sem apoio. Não se locomove com independência e apresenta dificuldades para manusear os objetos. Contudo, aceita ajuda e é bastante participativa nas atividades. Não fala, mas se comunica por meio de sons e gestos.

A gestação de L. não foi planejada, visto que sua mãe já havia feito cirurgia para não ter mais filhos. Aos oito meses de gestação, a mãe levou uma queda, o que a fez sentir-se mal. Ao ser levada para o hospital, demoraram a socorrê-la e para fazerem o parto, o que fez com que faltasse oxigênio para a criança (sic). A mãe teve complicações após o parto, tendo permanecido internada por mais de um mês, devido, segundo ela, a erros médicos. Logo após o nascimento, falaram que a criança apresentava problemas, contudo, nada foi explicado. A mãe só percebeu a deficiência quando a criança estava com oito meses de idade. Seu desenvolvimento foi lento; era um bebê muito mole e chorava muito. A criança faz tratamento (estimulação, fisioterapia e fonoaudiologia) na APAE, desde bebê. Atualmente faz acompanhamentos quinzenais.

Seus pais completaram o primeiro grau e L. está na $3^{\text {a }}$ série de uma escola comum, freqüentando uma classe comum com apoio de estagiária. Mora com a mãe, o pai (que não trabalha por apresentar problemas de saúde - limitações nos pés, causadas por diabetes) e cinco irmãos. A mãe relata um bom relacionamento da criança com a família e demais parentes, de 
modo que não há diferenças de tratamento destes em relação à criança. Às vezes, L. acompanha a família aos espaços da comunidade.

L. brinca com bola, mas sua brincadeira preferida é com bonecas. Também brinca com caixas, lápis, papel e cola. Não tem bichos de estimação e evita brincar com animais. Segundo a mãe, a criança obedece às regras das brincadeiras. Durante a semana, brinca um pouco de manhã, com a irmã; à tarde, na escola e, à noite, brinca um pouco, sozinha ou com a irmã. Nos finais de semana, brinca um pouco de manhã e à noite, com a irmã e/ou com o primo.

Do início ao final da pesquisa, apesar de demonstrar dúvidas no momento da escolha dos brinquedos, L. sempre escolhia brincar com massinha. Em 10 atendimentos, ela preferiu brincar com as forminhas. Em apenas uma sessão, escolheu brincar com os bichinhos de montar com a massinha. A Tabela 6.25 apresenta as brincadeiras oferecidas e as brincadeiras escolhidas pela criança.

Tabela 6.25 - Sujeito L.: brincadeiras oferecidas e brincadeiras escolhidas.

\begin{tabular}{|l|c|c|}
\hline Brincadeiras & Oferecidas & Escolhidas \\
\hline Carimbos & 5 & - \\
\hline Massinha & 11 & 10 \\
\hline Pescaria & 2 & - \\
\hline Zoológico & 4 & - \\
\hline Monte castelo & 9 & - \\
\hline Quadro imantado & 2 & - \\
\hline Vira Lata & 1 & - \\
\hline Bichos de massinha & 1 & 1 \\
\hline Carrinhos & 2 & - \\
\hline Fantoches e livros & 2 & - \\
\hline
\end{tabular}

Em sete atendimentos, a criança escolheu utilizar as forminhas para fazer figuras de massinha. Depois que ela retirava a massa de modelar da lata, a pesquisadora lhe mostrava que era necessário cortá-la ao “meio”, pois era muito "grande”. Ao preparar a massa para ser cortada com as forminhas, a pesquisadora sempre indicava as etapas da tarefa, utilizando os conceitos de 
“antes”, “depois” e “agora”. Antes de iniciarem a confecção das figuras, ela escolhia o que iriam fazer com estas. Em alguns atendimentos, brincaram de montar um zoológico, utilizando o cenário do brinquedo do zoológico, de modo que a criança escolhia de que "lado”, “direito" ou “esquerdo”, ficaria cada bicho, ou se ficaria "longe”, "perto” ou “entre” um bicho e o outro (a pesquisadora perguntava onde deveria colocá-los e nomeava a escolha da criança). A pesquisadora também sugeria que fizessem um lago para os patos no "centro” do parque (um círculo de papel ou tampa de uma lata), para que colocassem os demais bichos "em volta" do lago. Era indicado de qual lado havia "mais" ou "menos" bichos, sendo comentado que havia “muitos” bichos no zoológico. Em alguns momentos, utilizavam as cercas para colocá-las “em volta” dos bichos. Faziam ração e dividiam, dando um pedaço para “cada” bicho.

Em outros atendimentos, ao invés de fazerem um zoológico, a criança preferia fazer figuras que seriam dadas para a pesquisadora e para a estagiária, ou para o boneco e para a boneca (também feitos de massinha). Para separar as figuras de cada um, era colocado um pedaço de fita crepe "entre" eles. A criança, então, escolhia de que "lado", “esquerdo" ou "direito", colocaria cada figura. Era comentado se esta era "pequena” ou "grande”, também era mencionado quando um lado possuía “mais” figuras e o outro, “menos”. Faziam, então, mais figuras para o lado que possuía menos. Para finalizar, as figuras eram colocadas “em volta” do boneco correspondente (que ficava no "centro” das demais figuras), enquanto comentavam o que cada um possuía. Em uma sessão, também utilizaram três círculos de papel de diferentes tamanhos ("pequeno”, “médio” e "grande”) para fazerem três lagos para os peixes; os demais bichos foram distribuídos “em volta” dos lagos.

Em três atendimentos, a criança escolheu fazer comidinha com a massa de modelar. Fizeram batatas fritas e pizzas "pequenas”, “médias” e "grandes”. Para fazerem as pizzas, a pesquisadora mostrava que, “antes”, era necessário apertar a massa para, “depois”, alisá-la. Após 
alisarem a massa, a pesquisadora pedia ajuda da criança para cortarem, a fim de que a pizza ficasse redonda, comentando que "nunca" havia visto uma pizza quadrada. Enquanto a pesquisadora ajudava L. a preparar a massa, a estagiária fazia os tomates e a cebola para colocarem no "centro" da pizza e a irmã de L. fazia as bordas, que eram colocadas "em volta”. Cortavam a pizza pela “metade”, para dividirem entre as participantes.

L. escolheu uma única vez brincar com os bichinhos para montar com a massa de modelar. Ela preferiu, ao invés de utilizar o cenário do zoológico, dividir os bichos entre a pesquisadora e a estagiária, colocando uma parte dos bichos de cada "lado”, utilizando-se uma fita crepe para dividir a mesa. L. decidia em que bacia (“pequena”, "média” ou "grande”) colocaria as cabeças, as patas e os rabos dos bichos, sendo uma bacia para cada parte do corpo, a fim de que não se misturassem. Ela escolhia o bicho que gostaria de fazer e, então, era discutido qual cor seria a mais adequada para cada bicho. Quando a criança escolhia uma cor inadequada, por exemplo, a massinha rosa para fazer a girafa, a pesquisadora dizia que "nunca" havia visto uma girafa amarela com o corpo rosa. Enquanto a irmã fazia as bolinhas, a pesquisadora ajudava L. a encaixar, nesta bolinha, as partes do corpo do bicho. Quando faltava alguma parte do corpo, a pesquisadora dizia, por exemplo, que “nunca” havia visto uma girafa só com cabeça, sem as patas. Após fazer cada bicho, L. escolhia de que lado da mesa este ficaria, do "lado direito” ou do "lado esquerdo". Para guardar, colocaram as partes dos corpos dos bichos em suas respectivas bacias.

A criança era estimulada a participar ativamente de todas as etapas da brincadeira. Nos momentos das escolhas, a pesquisadora oferecia as opções apontando para as mesmas, então ela respondia, apontando para a opção desejada. L. era estimulada a executar com independência as tarefas que conseguia realizar, como, por exemplo, retirar a massa de modelar da lata. Porém, devido a sua dificuldade motora, era ajudada pela pesquisadora nos momentos necessários, como 
ao apertar e alisar a massa, fazer as figuras e retirá-las das forminhas. Em outros momentos, a pesquisadora executava a ação escolhida pela criança, colocando, por exemplo, as figuras nos locais indicados por ela. Isso acontecia porque, quando a criança segurava as figuras de massinha sem a ajuda da pesquisadora, destruía a figura, devido à incoordenação dos movimentos, o que a deixava frustrada. Contudo, ela não parecia se importar que esta parte da tarefa fosse executada pela pesquisadora, pois também podia participar ativamente, escolhendo os locais nos quais as figuras seriam colocadas.

L. costumava utilizar apenas a mão direita durante as atividades. Por este motivo, sua mãe sempre pedia para que utilizasse também a mão esquerda. A pesquisadora lhe explicou que seria melhor estimularem o uso da mão esquerda de modo indireto, sem ser necessário pedir diretamente para a criança utilizá-la. Assim, costumava estimular o uso de ambas as mãos, pedindo para a criança segurar objetos grandes e para fazer ações que exigiam o uso de ambas as mãos (como abrir a lata), ou dizendo que precisavam de todas as mãos para fazer bastante força (nestes momentos, todos os participantes deveriam ajudar, utilizando todas as mãos ‘disponíveis’). Estes eram momentos de descontração, nos quais a própria criança passou a pedir pela ajuda das pessoas presentes na sala (a estagiária, sua mãe ou irmã), fazendo cara de brava quando alguém não utilizava ambas as mãos.

A estagiária, após um atendimento, comentou que L. compreendia a pesquisadora apenas pelo olhar e expressão facial, não sendo necessário, em alguns momentos, que a pesquisadora falasse algo para que a criança compreendesse o que esta pensava (por exemplo, para usar ambas as mãos ou para pedir a ajuda da estagiária ou da mãe). Este fato parece indicar que, além de ter estabelecido um forte vínculo com as terapeutas, L. consegue se comunicar com grande facilidade a despeito de sua dificuldade para falar, pois se utilizava também de meios não verbais. 
Ela parecia compreender tudo o que acontecia e o que lhe era dito, rindo quando alguém derrubava algo, esquecia-se de alguma etapa da tarefa ou dizia algo incongruente.

A pesquisadora e a estagiária também nomeavam as ações e gestos da criança, atribuindolhes significado, de modo que estes se tornavam compartilhados entre os participantes na medida em que eram utilizados por ela. Como exemplo disto, em um atendimento, no momento em que a estagiária se queixava de que possuía menos bichos, L. riu e colocou a mão no rosto, rindo da estagiária. A pesquisadora nomeou esta ação da criança, dizendo “Ah, meu Deus”. A partir deste momento, sempre que alguém se queixava de algo, era realizado este gesto, o que fazia com que todos rissem.

A criança era muito participativa e colaborativa, sempre atenta à dinâmica das brincadeiras, engajando-se nas atividades simbólicas sugeridas pela pesquisadora. Contudo, em alguns poucos atendimentos, L. mostrou-se apática, o que parecia ser decorrente dos problemas graves que sua mãe enfrentava no momento. A irmã passou a levar a criança aos atendimentos. A família de L. preferiu não contar para ela sobre os problemas que estavam ocorrendo, contudo, a criança parecia perceber a situação, de modo que estava chorando com muita freqüência na escola, solicitando sempre pela presença da irmã na sala de aula.

A irmã de L. (com 14 anos de idade), assumiu todas as responsabilidades de sua casa e do tratamento de sua irmã na ausência de sua mãe. Assim, parecia estar aproveitando os atendimentos como um espaço para resgatar seus momentos lúdicos, demonstrando gostar muito de manipular a massinha e de participar das brincadeiras. Esta também estabeleceu um forte vínculo com a pesquisadora e a estagiária, não faltando a nenhum atendimento após ter assumido os cuidados com a irmã.

L. compareceu a 13 dos 16 atendimentos oferecidos. Contudo, os conceitos da pesquisa puderam ser trabalhados em apenas 11 atendimentos, visto que o primeiro e o último eram 
destinados à realização dos testes. Além deste fato, a criança chegou atrasada em algumas sessões, o que diminuiu ainda mais o tempo despendido nas brincadeiras. A Tabela 6.26 apresenta o número de sessões nas quais foram trabalhados os conceitos avaliados por meio do teste.

Tabela 6.26 - Sujeito L.: número e porcentagem de sessões em que os conceitos foram trabalhados nas brincadeiras.

\begin{tabular}{|l|c|c|}
\hline Conceito & No. de sessões & \% de sessões \\
\hline Em volta & 9 & 81,8 \\
\hline Menos & 7 & 63,6 \\
\hline Tamanho médio & 6 & 54,5 \\
\hline Lado direito & 5 & 45,5 \\
\hline Centro & 5 & 45,4 \\
\hline Depois & 4 & 36,4 \\
\hline Nunca & 2 & 18,2 \\
\hline Metade & 2 & 18,2 \\
\hline Entre & 2 & 18,2 \\
\hline Agora & 1 & 9,1 \\
\hline Muitos & 1 & 9,1 \\
\hline Logo & - & - \\
\hline Quase & - & - \\
\hline Cedo & - & - \\
\hline Debaixo & - & - \\
\hline
\end{tabular}

O conceito “em volta” foi o mais utilizado no decorrer das sessões (utilizado em 81,8\% dos atendimentos), seguido pelo conceito de "menos" (63,6\%) e "tamanho médio" (54,5\%). Em seguida, os conceitos mais trabalhados foram "lado direito" e “centro” (45,5\%).

Além dos conceitos avaliados por meio dos testes, outros conceitos também foram incluídos nas brincadeiras, sendo estes apresentados na Tabela 6.27. 
Tabela 6.27 - Sujeito L.: conceitos trabalhados nas brincadeiras, mas não avaliados pelo Teste de Boehm.

\begin{tabular}{|l|c|c|}
\hline Conceito & No. de sessões & \% de sessões \\
\hline Grande & 11 & 100 \\
\hline Pequeno & 10 & 90,9 \\
\hline Lado & 7 & 63,6 \\
\hline Mais & 7 & 63,6 \\
\hline Lado esquerdo & 5 & 45,5 \\
\hline Antes & 3 & 27,3 \\
\hline Meio & 2 & 18,2 \\
\hline Perto & 1 & 9,1 \\
\hline Longe & 1 & 9,1 \\
\hline Cada & 1 & 9,1 \\
\hline Dentro & 1 & 9,1 \\
\hline
\end{tabular}

Dentre estes conceitos, os mais utilizados no decorrer dos atendimentos foram os conceitos de "grande" (100\%) e "pequeno" (90,9\%), visto estarem relacionados ao conceito "tamanho médio”. O conceito de “mais” foi utilizado em 63,6\% dos atendimentos, em oposição ao conceito de “menos”. Os conceitos de "lado" (63,6\%) e "lado esquerdo" (45,5\%) também foram bastante trabalhados, visto serem relacionados ao conceito de "lado direito".

No decorrer da pesquisa, foi possível observar o desempenho de L. em atividades que envolviam conceitos de tamanho. Assim, no último mês da pesquisa, a criança sabia identificar corretamente objetos pequenos, médios e grandes em algumas situações. Ela apresentava mais facilidade quando estes objetos estavam dispostos em ordem crescente de tamanho ou quando, mesmo estando dispostos aleatoriamente, a pergunta era feita sequencialmente em ordem crescente. Uma vez identificados os objetos seguindo a ordem de tamanho, a criança já conseguia identificá-los quando solicitados aleatoriamente. No último dia de brincadeiras, L. soube identificar os tamanhos dos objetos dispostos fora da ordem de tamanho, mas ainda os confundiu, quando solicitados novamente. Este fato pode indicar que estes conceitos ainda não eram 
totalmente dominados, o que pôde ser observado no pós-teste, no qual a criança apontou para as três figuras antes de escolher a figura desejada, sendo esta última a correta.

A Tabela 6.28 apresenta os resultados de L. tanto no pré-teste quanto no pós-teste.

Tabela 6.28 - Sujeito L.: resultados do pré e pós-teste, no Teste de Boehm.

\begin{tabular}{|c|c|c|}
\hline Conceitos & Pré-teste & Pós-teste \\
\hline 1 - Inst. Sapato & A & A \\
\hline 2 - Inst. Banana & A & A \\
\hline 3 - Inst. Carro & A & A \\
\hline 4 - Inst. Mesa & A & A \\
\hline 5 - Inst. Copo & $\mathrm{A}$ & $\mathrm{A}$ \\
\hline 6 - Inst. Cachorro & A & A \\
\hline Total - instrução & 6 & 6 \\
\hline 1 - Depois & $E_{c}$ & $E_{c}$ \\
\hline 2 - Centro & $E$ & A \\
\hline 3-Quase & A & A \\
\hline 4-Em volta & $E_{b}$ & A \\
\hline $5-$ Cedo & A & A \\
\hline 6-Nunca & $E_{c}$ & $E_{c}$ \\
\hline 7 - Metade & $\mathrm{A}$ & $\mathrm{A}$ \\
\hline 8 - Lado direito & $E_{b}$ & $E_{a}$ \\
\hline 9 - Tam. Médio & $E_{b}$ & A \\
\hline $10-$ Menos & A & A \\
\hline 11 - Entre & A & A \\
\hline $12-$ Logo & A & E? \\
\hline 13 - Debaixo & A & A \\
\hline 14-Muitas & $\mathrm{A}$ & $\mathrm{A}$ \\
\hline 15 - Agora & $E_{b}$ & $E_{b}$ \\
\hline Total - acertos & 8 & 10 \\
\hline
\end{tabular}

No pré-teste, L. acertou todas as questões de instrução. Para indicar a opção escolhida, apontava para a resposta com o dedo indicador, embora apresentasse incoordenação do movimento. Quando mostrava mais de um desenho, a pesquisadora pedia para que escolhesse apenas um. Mostrou-se atenta ao teste, embora tenha se dispersado em um pequeno momento.

No pós-teste, a criança também colaborou de maneira adequada. Quando mostrava mais de uma opção, a pesquisadora pedia para que pensasse e escolhesse apenas uma. Na questão 
referente ao conceito de "nunca" (utilizado em apenas 18,2\% dos atendimentos), antes de responder a questão errada, L. havia mostrado a opção correta. No conceito de "muitas” (9,1\%), L. escolheu a opção correta, mas antes havia mostrado a opção A, o que parece indicar que o conceito está em processo de aprendizagem. Na pergunta referente ao conceito de "tamanho médio” (54,5\%), antes de escolher a opção correta, a criança havia mostrado todas as opções, o que pode indicar que o conceito ainda não era completamente dominado por ela.

Na questão correspondente ao conceito de "lado direito” (45,5\%), L. escolheu a opção B, no pré-teste (figura que estava no centro da cartela). Já no pós-teste, escolheu a opção A, que, embora não seja a correta, é correspondente a um lado, o que pode indicar que a criança tenha apreendido o conceito de lado (trabalhado em 63,6\% dos atendimentos).

L. acertou os conceitos "em volta" (trabalhado em 81,8\% dos atendimentos), "tamanho médio” (54,5\%) e “centro” (45,4\%), que havia errado no pré-teste. A questão referente ao conceito de "logo", que a criança havia acertado no pré-teste, foi considerada como errada no pós-teste, visto que ela parecia não se decidir entre a opção correta e a incorreta. Assim, embora a diferença entre os resultados do pré-teste e do pós-teste seja de apenas dois pontos, L. acertou, no pós-teste, três conceitos que havia errado no pré-teste, sugerindo que estes foram desenvolvidos no decorrer da pesquisa. 


\subsection{Uma síntese dos resultados}

Embora não seja a finalidade deste trabalho comparar a evolução das crianças acompanhadas, mas observar o desenvolvimento de cada uma delas no decorrer da pesquisa, serão mencionados alguns pontos em comum e algumas diferenças entre os casos que podem auxiliar na discussão dos dados da pesquisa.

No que se refere a suas características pessoais, a idade média das crianças participantes era de oito anos e sete meses no início da pesquisa, sendo F. a criança mais nova, com seis anos e 11 meses, e FR. a criança mais velha, com dez anos e 11 meses. F. era a criança com o menor comprometimento motor, sendo a única que não necessitava de cadeira de rodas para a locomoção (utilizando-se de muletas canadenses). Desta forma, esta criança realizava com maior independência todas as suas atividades e possuía, conforme avaliado pelos questionários, mais oportunidades para brincar. Também era a única criança que não apresentava nenhuma dificuldade para a fala.

Assim como F., FR. e E. também apresentavam o diagnóstico de diparesia espástica. Embora apresentasse dificuldades, FR. realizava as transferências com independência, enquanto E. necessitava de auxílio para as mesmas, o que dificultava a sua participação nas atividades lúdicas. Tanto FR. quanto E. apresentavam alterações na fala, contudo FR. conseguia estabelecer uma comunicação verbal efetiva, apresentando apenas dificuldades para falar algumas palavras; por outro lado, E. falava apenas algumas palavras isoladas, comunicando-se preferencialmente por sons e gestos.

As demais crianças, com o diagnóstico de tetraparesia, apresentavam um maior comprometimento motor. Destas, apenas B. conseguia falar algumas palavras, mas era pouco comunicativa. Esta criança, bem como N., apresentava tetraparesia espástica, enquanto que V. e 
L. apresentavam tetraparesia atetóide com componente espástico, o que acarreta movimentação involuntária, prejudicando ainda mais a sua coordenação motora.

As mães de todas as crianças relataram intercorrências durante a gestação ou durante o parto, sendo que apenas a mãe de FR. relata não ter sido difícil compreender e aceitar que seu filho apresentava uma deficiência. Com exceção de FR., V. e E., as demais crianças possuem irmãos, o que favorece a realização de brincadeiras com outras crianças. Todas as crianças avaliadas acompanham suas famílias aos passeios, festas e espaços da comunidade, tais como igreja e mercado, com exceção de L., que nem sempre participa de tais atividades.

Os pais de F. e L. haviam cursado o primeiro grau completo, enquanto que os pais das demais crianças apresentavam o primeiro grau incompleto ou haviam cursado apenas o ensino fundamental. Apesar do baixo nível de escolaridade dos pais, todas as crianças estavam matriculadas em algum tipo de escola: F. freqüentava uma pré-escola comum, enquanto $\mathrm{N}$. freqüentava uma pré-escola especial; FR., B. e E. freqüentavam escolas comuns, sendo que os dois primeiros estavam na $1^{\mathrm{a}}$ série, enquanto E. cursava a $3^{\mathrm{a}}$ série; V. e L. freqüentavam a $3^{\mathrm{a}}$ série comum com apoio de estagiária.

Todas as mães relataram que as crianças realizavam algum tipo de atividade lúdica, sendo mais citadas brincadeiras que envolviam brinquedos tais como bolas, carrinhos e bonecos. As mães de N. e E. relataram que as crianças gostavam muito de assistir à televisão, sendo que, no caso de N., sua mãe acreditava que a televisão estava dificultando o desenvolvimento do filho, visto que a criança deixava de brincar para assistir a ela. FR. e N. eram as crianças com menos oportunidades para brincar durante a semana, enquanto que, nos finais de semana, E. era a criança com menos oportunidades. Todas as crianças realizavam, no início da pesquisa, tratamentos de reabilitação, o que parecia reduzir as oportunidades para realizar brincadeiras livres no dia a dia. 
No decorrer da pesquisa, foram oferecidos 16 atendimentos para cada criança, com exceção de FR., para o qual foram oferecidos 15 encontros devido à ocorrência de um grande número de feriados no período em que foi acompanhado. As crianças participaram efetivamente de uma média de 13,3 encontros, sendo que N. freqüentou o menor número de sessões (10) e B., o maior número, participando de todos os atendimentos (16).

Todos os acompanhantes foram convidados a participar dos momentos de brincadeiras. Contudo, apenas o padrasto de V. e a irmã de L. aceitaram participar efetivamente das mesmas, enquanto que as mães de N. e de B. preferiram apenas observar os atendimentos. A tia de E. e as mães de F. e de L. preferiram aguardar na sala de espera. Embora a mãe de FR. preferisse observar as brincadeiras, não foi possível permitir a sua permanência na sala de atendimentos, visto que ela interferia nas brincadeiras, brigando com o filho ou tentando conversar com a pesquisadora sobre outros assuntos não pertinentes às atividades lúdicas.

As brincadeiras mais oferecidas às crianças da pesquisa foram: zoológico, massinha, carimbos, bolinhas, Monte Castelo, pescaria e bichinhos de massinha. Também foram oferecidos, embora com menor freqüência, os seguintes brinquedos: Vira Lata, quadro com figuras imantadas, fantoches com livrinhos, corrida de carrinhos, cidade, Super-pinão, carrinhos, tinta e pincel, dedoches da Turma da Mônica e gibis, varetas gigantes, jogo da memória dos “Ursinhos e seus Amigos”, dominó de metades, macacão com bolinhas de velcro, palhaços equilibristas, jogo de argolas, rolos e/ou cones para derrubar com bolas, boneca, Caça ao Tesouro e futebol de bolinhas de gude. As brincadeiras que despertaram muito o interesse das crianças, de modo que mais de uma criança quis repeti-las no decorrer dos atendimentos, foram as seguintes: carimbos, massinha, pescaria e jogo da memória dos "Ursinhos e seus Amigos”. Outras brincadeiras também despertaram o interesse de alguma das crianças, sendo estas as que se seguem: bichinhos de massinha, zoológico, cidade, Vira Lata, bolinhas, quadro com figuras imantadas e fantoches 
com livrinhos. F., FR. e B. foram crianças que escolheram a maior variedade de brincadeiras e L. e V., a menor variedade, repetindo com maior freqüência as mesmas atividades.

Devido às dificuldades motoras, algumas crianças (N., V. e L.) necessitaram de ajuda para conseguirem manipular com sucesso os objetos, de modo que a pesquisadora precisava auxiliálas durante as brincadeiras. Outras crianças (B. e E.) necessitaram de ajuda apenas para as transferências da cadeira de rodas para o local onde a brincadeira seria realizada. F. não necessitou de ajuda, enquanto FR. necessitou de pouco auxílio, apenas nas atividades que exigiam o uso de ambas as mãos, tais como recortar com a tesoura. Todas as crianças apresentaram uma postura bastante ativa durante os atendimentos, mostrando-se interessadas e atentas à dinâmica das brincadeiras, com exceção de B., que apresentou uma postura mais passiva, de modo que a pesquisadora precisou interferir mais nas atividades, visando manter a atenção da criança. As crianças que necessitavam, pareciam não se importar com o auxílio oferecido; contudo, além de estimular que a criança executasse parte da ação, a pesquisadora sempre reduzia a ajuda conforme a criança apresentava maior domínio da tarefa.

De acordo com a brincadeira escolhida, a pesquisadora falava com a criança sobre as etapas da mesma, as ações realizadas em cada momento e, conforme fosse oportuno, nomeava os conceitos envolvidos na situação. Embora alguns conceitos tenham sido mencionados uma única vez no relato de cada brincadeira, a pesquisadora os repetia algumas vezes no decorrer do atendimento, conforme fosse necessário e oportuno. Em alguns momentos, a pesquisadora inseria, com a autorização da criança, algum elemento novo na brincadeira, o qual possibilitava a inclusão de algum conceito específico. Como exemplo, podemos mencionar o momento em que, ao brincarem de fazer figuras de bichos com a massinha de modelar, a pesquisadora sugeriu que fizessem um lago, para colocarem um peixe no “centro" e os demais bichos “em volta”. Desta 
forma, era possível a inclusão dos conceitos pesquisados sem, contudo, desviar o foco de atenção da criança para a brincadeira que estava sendo realizada.

Após a brincadeira, a criança sempre auxiliava a pesquisadora a guardar o brinquedo utilizado. Nestes momentos, sempre que necessário, a criança era solicitada a guardar um tipo de objeto em uma caixa e outro tipo, em outra, estimulando a identificação e a classificação dos mesmos. Depois de guardado, era nomeado se o brinquedo seria colocado “debaixo” do tablado, “em cima” da mesa, “dentro” ou “em cima” do armário, envolvendo, portanto, alguns conceitos de espaço. Foi possível observar que esta conduta também possibilitou que a criança aceitasse melhor o momento de guardar os objetos, pois sabia onde o brinquedo estaria guardado, sabendo como recuperá-lo futuramente.

Dentre os conceitos avaliados por meio dos testes, os mais trabalhados durante as brincadeiras (utilizados em ao menos $40 \%$ dos atendimentos de alguma criança) foram os seguintes: “depois”, “menos”, “lado direito”, “tamanho médio”, “centro”, “debaixo”, “metade”, “muitos”, “quase”, “agora” e “em volta”. Os conceitos de “cedo” e "logo” não foram utilizados em nenhum atendimento.

Alguns outros conceitos que não faziam parte desta pesquisa também foram trabalhados durante as brincadeiras, de acordo com as necessidades de cada situação específica. Dentre estes conceitos, os mais freqüentes foram: “lado”, “lado esquerdo”, “grande”, “pequeno”, “dentro” e “mais".

Visando identificar os conceitos não dominados pelas crianças e que, portanto, precisariam ser trabalhados por meio das brincadeiras, no início da pesquisa foi aplicado o Teste de Conceitos Básicos de Boehm Adaptado. A Tabela 6.29 apresenta os resultados do pré-teste obtidos por todas as crianças incluídas na pesquisa. 
Tabela 6.29 - Resultados do pré-teste aplicado às crianças da pesquisa.

\begin{tabular}{|c|c|c|c|c|c|c|c|c|c|}
\hline Crianças / conceitos & N. & F. & B. & FR. & V. & E. & L. & Acertos & $\%$ \\
\hline 1 - Inst. Sapato & A & $\mathrm{A}$ & A & A & $\mathrm{A}$ & $\mathrm{E}$ & $\mathrm{A}$ & 6 & 85,7 \\
\hline 2 - Inst. Banana & A & A & $\mathrm{A}$ & A & A & A & A & 7 & 100 \\
\hline 3 - Inst. Carro & A & $\mathrm{A}$ & $\mathrm{A}$ & A & $\mathrm{A}$ & $\mathrm{A}$ & $\mathrm{A}$ & 7 & 100 \\
\hline 4 - Inst. Mesa & $\mathrm{A}$ & $\mathrm{A}$ & $\mathrm{E}$ & A & $\mathrm{A}$ & $\mathrm{A}$ & $\mathrm{A}$ & 6 & 85,7 \\
\hline 5 - Inst. Copo & $\mathrm{A}$ & $\mathrm{A}$ & A & A & $\mathrm{A}$ & $\mathrm{E}$ & $\mathrm{A}$ & 6 & 85,7 \\
\hline 6 - Inst. Cachorro & A & A & A & A & A & $\mathrm{A}$ & $\mathrm{A}$ & 7 & 100 \\
\hline Total - instrução & 6 & 6 & 5 & 6 & 6 & 4 & 6 & - & - \\
\hline 1 - Depois & $E_{c}$ & $\mathrm{~A}$ & $E_{b}$ & $E_{c}$ & $E_{c}$ & $\mathrm{~A}$ & $E_{c}$ & 2 & 28,6 \\
\hline 2 -Centro & $\mathrm{E}$ & $\mathrm{A}$ & $\mathrm{E}$ & $\mathrm{E}$ & $\mathrm{A}$ & $\mathrm{A}$ & $\mathrm{E}$ & 3 & 42,8 \\
\hline 3-Quase & $\mathrm{A}$ & $\mathrm{A}$ & $\mathrm{E}$ & A & $\mathrm{A}$ & $E_{a}$ & $\mathrm{~A}$ & 5 & 71,4 \\
\hline $4-$ Em volta & $E_{c}$ & $\mathrm{~A}$ & $\mathrm{E}$ & $\mathrm{E}_{\mathrm{c}}$ & $E_{c}$ & $\mathrm{~A}$ & $E_{b}$ & 2 & 28,6 \\
\hline 5 - Cedo & A? & $\mathrm{A}$ & $\mathrm{E}_{\mathrm{b}}$ & $A$ & A & $\mathrm{A}$ & $\mathrm{A}$ & 6 & 85,7 \\
\hline 6- Nunca & $\mathrm{E}_{\mathrm{ca}}$ & A & $E_{a}$ & $E_{c}$ & $E_{c}$ & $E_{a}$ & $E_{c}$ & 1 & 14,3 \\
\hline 7 - Metade & $E_{c}$ & $\mathrm{~A}$ & $\mathrm{E}$ & $\mathrm{A}$ & $E_{c}$ & $E_{c}$ & $\mathrm{~A}$ & 3 & 42,8 \\
\hline 8 - Lado direito & A? & A? & $E_{a}$ & A? & $E_{b}$ & $\mathrm{~A}$ & $E_{b}$ & 4 & 57,1 \\
\hline 9 - Tam. Médio & $\mathrm{E}_{\mathrm{b}}$ & $\mathrm{A}$ & A? & $\mathrm{E}_{\mathrm{b}}$ & $E_{b}$ & $E_{b}$ & $E_{b}$ & 2 & 28,6 \\
\hline 10 - Menos & $\mathrm{E}_{\mathrm{b}}$ & $E_{a}$ & $\mathrm{E}_{\mathrm{a}}$ & A & $E_{b}$ & $E_{b}$ & $\mathrm{~A}$ & 2 & 28,6 \\
\hline 11 - Entre & A? & $\mathrm{A}$ & $\mathrm{E}$ & $E_{c}$ & $E_{c}$ & $\mathrm{~A}$ & $\mathrm{~A}$ & 4 & 57,1 \\
\hline 12 - Logo & $\mathrm{E}_{\mathrm{b}}$ & $\mathrm{A}$ & $E$ & $\mathrm{~A}$ & A & $\mathrm{A}$ & $\mathrm{A}$ & 5 & 71,4 \\
\hline 13 - Debaixo & $\mathrm{E}$ & $\mathrm{A}$ & $\mathrm{E}$ & $A$ & A & $\mathrm{A}$ & $\mathrm{A}$ & 5 & 71,4 \\
\hline $14-$ Muitas & $\mathrm{E}$ & $\mathrm{A}$ & A? & $\mathrm{A}$ & $\mathrm{A}$ & $E_{a}$ & $\mathrm{~A}$ & 5 & 71,4 \\
\hline 15-Agora & $\mathrm{A}$ & $\mathrm{A}$ & A? & $\mathrm{A}$ & $\mathrm{A}$ & $E_{b}$ & $E_{b}$ & 5 & 71,4 \\
\hline Total - acertos & 5 & 14 & 3 & 9 & 7 & 8 & 8 & - & - \\
\hline
\end{tabular}

Como é possível observar, cinco crianças acertaram todas as questões de instrução, o que mostra que elas dominam estes conceitos referentes a objetos presentes no dia a dia. No que se refere ao teste propriamente dito, as crianças da pesquisa apresentaram os maiores índices de acertos nas questões referentes aos conceitos de “cedo” (85,7\%), “quase”, “logo”, “debaixo”, “muitas” e “agora” (71,4\%), seguidos pelos conceitos “lado direito” e “entre” (57,1\%). Os conceitos que obtiveram os menores índices de acertos foram "nunca” (14,3\%), "tamanho médio”, “depois”, “em volta” e “menos” (28,6\%). Embora quatro crianças tenham acertado a questão referente ao conceito de "lado direito”, foi possível observar, após a realização do préteste e durante as brincadeiras, que duas destas crianças (F. e FR.) não dominavam este conceito 
em situações práticas. As outras duas crianças (N. e E.), não acertaram esta questão no pós-teste, o que indica que tenham acertado esta questão, no pré-teste, por acaso.

Visto a dificuldade de avaliar se as crianças da pesquisa apresentavam um atraso no desenvolvimento dos conceitos, os resultados por elas apresentados foram comparados com os resultados obtidos por crianças de uma creche situada no município de São Paulo. Na ocasião, conforme mencionado anteriormente (Capítulo 5), o teste foi aplicado visando avaliar as adaptações realizadas no Teste de Conceitos Básicos de Boehm. As crianças da creche que participaram desta etapa do trabalho de pesquisa apresentavam uma idade média de 5 anos e 6 meses, enquanto que as crianças com paralisia cerebral participantes da pesquisa apresentavam uma idade média de 8 anos e 9 meses. Na Tabela 6.30, os resultados das crianças da creche são comparados com os resultados obtidos no pré-teste pelas crianças com paralisia cerebral incluídas nesta pesquisa. 
Tabela 6. 30 - Resultados das crianças da creche e das crianças da pesquisa.

\begin{tabular}{|l|c|c|c|}
\hline $\begin{array}{l}\text { Alunos } \\
\text { Conceitos }\end{array}$ & $\begin{array}{c}\text { Crianças da } \\
\text { creche \% (A) }\end{array}$ & $\begin{array}{c}\text { Crianças da } \\
\text { pesquisa \% (B) }\end{array}$ & $\begin{array}{c}\text { Diferença A-B } \\
\text { \% }\end{array}$ \\
\hline 1 - Inst. Sapato & 100 & 85,7 & 14,3 \\
\hline 2 - Inst. Banana & 100 & 100 & 0 \\
\hline 3 - Inst. Carro & 100 & 100 & 0 \\
\hline 4 - Inst. Mesa & 100 & 85,7 & 14,3 \\
\hline 5 - Inst. Copo & 100 & 85,7 & 14,3 \\
\hline 6 - Inst. Cachorro & 100 & 100 & 0 \\
\hline 1 - Depois & 61,5 & 28,6 & 32,9 \\
\hline 2 - Centro & 84,6 & 42,8 & 41,8 \\
\hline 3 - Quase & 100 & 71,4 & 28,6 \\
\hline 4 - Em volta & 92,3 & 28,6 & 63,7 \\
\hline 5 - Cedo & 38,5 & 85,7 & $-47,2$ \\
\hline 6 - Nunca & 61,5 & 14,3 & 47,2 \\
\hline 7 - Metade & 69,2 & 42,8 & 26,4 \\
\hline 8 - Lado direito & 7,7 & 57,1 & $-49,4$ \\
\hline 9 - Tam. Médio & 69,2 & 28,6 & 40,6 \\
\hline 10 - Menos & 23,1 & 28,6 & $-5,5$ \\
\hline 11 - Entre & 61,5 & 57,1 & 4,4 \\
\hline 12 - Logo & 100 & 71,4 & 28,6 \\
\hline 13 - Debaixo & 100 & 71,4 & 28,6 \\
\hline 14 - Muitas & 100 & 71,4 & 28,6 \\
\hline 15 - Agora & 100 & 71,4 & 28,6 \\
\hline
\end{tabular}

Como é possível observar, as crianças da creche apresentaram um maior número de acertos em quase todas as questões, com exceção das questões referentes aos conceitos de "lado direito", “cedo” e “menos”. Contudo, conforme relatado anteriormente, das quatro crianças da pesquisa que acertaram a questão correspondente ao conceito de "lado direito”, duas não dominavam tal conceito em situações práticas e duas parecem ter acertado por acaso, pois a erraram no pós-teste. Assim, embora não seja o objetivo deste trabalho comparar o desempenho de crianças com ou sem deficiência, tais resultados servem para indicar que, com exceção de F., as crianças com paralisia cerebral avaliadas nesta pesquisa apresentam um atraso no desenvolvimento da maioria dos conceitos em tela. 
Ao agruparmos os conceitos avaliados por domínios de conhecimento (conceitos de tempo, espaço e quantidade), não encontramos grandes diferenças entre o número de acertos nas questões referentes a cada conceito e o domínio ao qual o conceito pertence. Este dado pode ser justificado pelo fato de que tais conceitos se encontram em diferentes níveis de dificuldade, visto que foram selecionados para esta pesquisa tomando-se por base uma consulta realizada com professores da pré-escola, da $1^{\text {a }}$ e da $2^{\mathrm{a}}$ séries do primeiro grau (conforme descrito no Capítulo 5). Assim, para cada domínio de conhecimento, foram selecionados conceitos considerados fáceis, médios e difíceis para crianças entre seis e oito anos de idade. A Tabela 6.31 apresenta os resultados das crianças da creche e da pesquisa comparados com as respostas dos professores quanto ao nível de dificuldade de cada conceito incluído neste estudo.

Tabela 6.31 - Acertos das crianças e avaliação dos professores.

\begin{tabular}{|l|l|c|c|l|}
\hline $\begin{array}{l}\text { Domínio de } \\
\text { Conhecimento }\end{array}$ & Conceito & $\begin{array}{c}\text { Crianças da } \\
\text { Creche (\%) }\end{array}$ & $\begin{array}{c}\text { Crianças da } \\
\text { pesquisa (\%) }\end{array}$ & $\begin{array}{l}\text { Nível de } \\
\text { dificuldade }\end{array}$ \\
\hline \multirow{4}{*}{ Quantidade } & Quase & 100 & 71,4 & Médio \\
\cline { 2 - 5 } & Metade & 69,2 & 42,8 & Médio \\
\cline { 2 - 5 } & Menos & 23,1 & 28,6 & Médio \\
\cline { 2 - 5 } & Muitas & 100 & 71,4 & Fácil \\
\cline { 2 - 5 } & Tamanho médio & 69,2 & 28,6 & Difícil \\
\hline \multirow{5}{*}{ Espaço } & Em volta & 92,3 & 28,6 & Médio \\
\cline { 2 - 5 } & Centro & 84,6 & 42,8 & Médio \\
\cline { 2 - 5 } & Lado direito & 7,7 & 57,1 & Médio / difícil \\
\cline { 2 - 5 } & Entre & 61,5 & 57,1 & Médio \\
\cline { 2 - 5 } & Debaixo & 100 & 71,4 & Fácil \\
\hline \multirow{5}{*}{ Tempo } & Depois & 61,5 & 28,6 & Fácil / médio \\
\cline { 2 - 5 } & Cedo & 38,5 & 85,7 & Médio \\
\cline { 2 - 5 } & Nunca & 61,5 & 14,3 & Médio \\
\cline { 2 - 5 } & Logo & 100 & 71,4 & Médio \\
\cline { 2 - 5 } & Agora & 100 & 71,4 & Fácil \\
\hline
\end{tabular}

Visando verificar se houve concordância no que se refere à avaliação dos professores e o nível de dificuldade encontrado pelas crianças no teste de conceito adaptado, utilizamos o seguinte critério: conceito fácil -100 a 66 \% de acertos; conceito médio - 65 a $34 \%$ de acertos; 
conceito difícil - 33 a 0\% de acertos. Deste modo, podemos verificar que os conceitos “muitas”, “debaixo” e “agora”, que se mostraram fáceis para as crianças, também receberam tal julgamento por parte dos professores. Também houve concordância quanto aos conceitos “entre” e "metade”, que se mostraram num nível médio de dificuldade para ambos os grupos. Se considerarmos que os acertos para a questão relacionada ao conceito de "lado direito" ocorreu ao acaso para duas crianças da pesquisa, também encontraremos concordância entre o nível de dificuldade e a avaliação dos professores.

Alguns conceitos apresentaram um nível de dificuldade semelhante para os grupos de crianças, mas não houve concordância com a avaliação dos professores. Os conceitos “logo” e “quase”, considerados médios pelos professores, mostraram-se fáceis para ambos os grupos de crianças. Já com conceito de “menos”, julgado médio pelos professores, mostrou-se difícil para as crianças avaliadas.

Para os demais conceitos, não houve concordância entre as respostas dos grupos ou entre uma destas respostas e a avaliação dos professores. Os conceitos “depois” e “nunca”, avaliados como médios pelos professores, mostraram-se médios apenas para as crianças da creche, mas difíceis para as crianças com paralisia cerebral. Os professores consideraram médio o conceito “centro”, mas este se mostrou médio apenas para as crianças da pesquisa, sendo fácil para as crianças da creche. O conceito de "tamanho médio", considerado difícil para as crianças da pesquisa e fácil para as crianças da creche, foi julgado como difícil pelos professores. Ao contrário, o conceito de “cedo”, considerado médio pelos professores, mostrou-se médio para as crianças da creche, mas fácil para as crianças da pesquisa. Quanto ao conceito “em volta”, não houve concordância com nenhum dos grupos, sendo considerado médio pelos professores, difícil para as crianças com paralisia cerebral e fácil para as crianças da creche. 
No final da pesquisa, após a realização das sessões com brincadeiras que envolviam conceitos não dominados por cada criança com paralisia cerebral, foi realizado o pós-teste, que visava identificar os conceitos que foram aprendidos no decorrer dos atendimentos. A Tabela 6.32 apresenta os resultados obtidos no pós-teste pelas crianças com paralisia cerebral.

Tabela 6. 32 - Resultados do pós-teste aplicado às crianças da pesquisa.

\begin{tabular}{|c|c|c|c|c|c|c|c|c|c|}
\hline Crianças / conceitos & $\mathbf{N}$. & F. & B. & FR. & V. & E. & L. & Total & $\%$ \\
\hline 1 - Inst. Sapato & A & A & A & A & $\mathrm{A}$ & A & A & 7 & 100 \\
\hline 2 - Inst. Banana & A & $\mathrm{A}$ & $\mathrm{A}$ & A & $\mathrm{A}$ & $\mathrm{A}$ & $\mathrm{A}$ & 7 & 100 \\
\hline 3 - Inst. Carro & $\mathrm{A}$ & $\mathrm{A}$ & $\mathrm{A}$ & A & $\mathrm{A}$ & $\mathrm{A}$ & $\mathrm{A}$ & 7 & 100 \\
\hline 4 - Inst. Mesa & $\mathrm{A}$ & $\mathrm{A}$ & $\mathrm{E}$ & $\mathrm{A}$ & $\mathrm{A}$ & $\mathrm{A}$ & $\mathrm{A}$ & 6 & 85,7 \\
\hline 5 - Inst. Copo & A & A & A & A & $\mathrm{A}$ & A & A & 7 & 100 \\
\hline 6 - Inst. Cachorro & $\mathrm{A}$ & $\mathrm{A}$ & $\mathrm{A}$ & A & $\mathrm{A}$ & $\mathrm{A}$ & $\mathrm{A}$ & 7 & 100 \\
\hline Total - instrução & 6 & 6 & 5 & 6 & 6 & 6 & 6 & & \\
\hline 1 - Depois & A & A & $E_{b}$ & $E_{c}$ & $\mathrm{~A}$ & $\mathrm{~A}$ & $E_{c}$ & 4 & 57,1 \\
\hline 2 - Centro & A? & $\mathrm{A}$ & $\mathrm{E}$ & $\mathrm{A}$ & $\mathrm{E}$ & $\mathrm{A}$ & $\mathrm{A}$ & 5 & 71,4 \\
\hline 3-Quase & $\mathrm{A}$ & $\mathrm{A}$ & $\overline{E_{b}}$ & $\bar{A}$ & $\mathrm{~A}$ & $\overline{E_{a}}$ & $\mathrm{~A}$ & 5 & 71,4 \\
\hline $4-$ Em volta & $E_{c}$ & $\mathrm{~A}$ & $E_{c}$ & A & $\mathrm{A}$ & $E_{c}$ & A & 4 & 57,1 \\
\hline 5 - Cedo & $\mathrm{E}_{\mathrm{a}}$ & $\mathrm{A}$ & $\mathrm{E}_{\mathrm{b}}$ & $\mathrm{A}$ & $\mathrm{A}$ & A & $\mathrm{A}$ & 5 & 71,4 \\
\hline $6-$ Nunca & $E_{c}$ & $\mathrm{~A}$ & $E_{a}$ & $E_{c}$ & $\mathrm{E}_{\mathrm{a}}$ & $E_{c}$ & $E_{c}$ & 1 & 14,3 \\
\hline 7 - Metade & $E_{c}$ & $\mathrm{~A}$ & $E_{c}$ & $\mathrm{~A}$ & $E_{c}$ & $E_{b}$ & $\mathrm{~A}$ & 3 & 42,8 \\
\hline 8 - Lado direito & $E_{a}$ & A? & $\mathrm{E}_{\mathrm{b}}$ & A & $\mathrm{E}_{\mathrm{b}}$ & $E_{a}$ & $E_{a}$ & $2 ?$ & 28,6 \\
\hline 9- Tam. Médio & $\mathrm{E}_{\mathrm{b}}$ & $\mathrm{A}$ & $E_{b}$ & $\mathrm{E}_{\mathrm{b}}$ & $\mathrm{E}_{\mathrm{b}}$ & $E_{b}$ & A? & 2 & 28,6 \\
\hline $10-$ Menos & $\mathrm{A}$ & A? & A? & A & $E_{a}$ & $\mathrm{~A}$ & $\mathrm{~A}$ & 6 & 85,7 \\
\hline 11 - Entre & $\mathrm{E}_{\mathrm{c}}$ & A & $\mathrm{E}_{\mathrm{c}}$ & A & $\mathrm{E}$ & $E_{c}$ & A & 3 & 42,8 \\
\hline $12-$ Logo & $\mathrm{E}_{\mathrm{c}}$ & $\mathrm{A}$ & $\overline{E_{a b}}$ & A & $\mathrm{A}$ & $\mathrm{A}$ & E? & 4 & 57,1 \\
\hline 13 - Debaixo & $\mathrm{A}$ & $\mathrm{A}$ & $\mathrm{A}$ & $\mathrm{A}$ & $\mathrm{A}$ & $\mathrm{A}$ & $\mathrm{A}$ & 7 & 100 \\
\hline 14 - Muitas & $E_{a}$ & $\mathrm{~A}$ & $E_{a}$ & A & $\mathrm{A}$ & $\mathrm{A}$ & $\mathrm{A}$ & 5 & 71,4 \\
\hline 15 - Agora & $\mathrm{A}$ & A & $\mathrm{E}_{\mathrm{bc}}$ & A & $\mathrm{A}$ & A & $\mathrm{E}_{\mathrm{b}}$ & 5 & 71,4 \\
\hline Total - acertos & 6 & 15 & 2 & 12 & 8 & 8 & 10 & & \\
\hline
\end{tabular}

A Tabela 6.33 compara os resultados apresentados pelas crianças no início e no final da pesquisa, permitindo comparar se, de modo geral, houve um aumento no número de acertos em cada questão. 
Tabela 6. 33 - Comparação entre os resultados obtidos pelas crianças no pré-teste e no pós-teste.

\begin{tabular}{|l|c|c|c|}
\hline Crianças / conceitos & $\begin{array}{c}\text { Pré-teste (\%) } \\
\text { A }\end{array}$ & $\begin{array}{c}\text { Pós-teste (\%) } \\
\text { B }\end{array}$ & Diferença (B - A) \\
\hline 1 - Inst. Sapato & 85,7 & 100 & $\mathbf{1 4 , 3}$ \\
\hline 2 - Inst. Banana & 100 & 100 & $\mathbf{0}$ \\
\hline 3 - Inst. Carro & 100 & 100 & $\mathbf{0}$ \\
\hline 4 - Inst. Mesa & 85,7 & 85,7 & $\mathbf{0}$ \\
\hline 5 - Inst. Copo & 85,7 & 100 & $\mathbf{1 4 , 3}$ \\
\hline 6 - Inst. Cachorro & 100 & 100 & $\mathbf{0}$ \\
\hline 1 - Depois & 28,6 & 57,1 & $\mathbf{2 8 , 5}$ \\
\hline 2 - Centro & 42,8 & 71,4 & $\mathbf{2 8 , 6}$ \\
\hline 3 - Quase & 71,4 & 71,4 & $\mathbf{0}$ \\
\hline 4 - Em volta & 28,6 & 57,1 & $\mathbf{2 8 , 5}$ \\
\hline 5 - Cedo & 85,7 & 71,4 & $\mathbf{- 1 4 , 3}$ \\
\hline 6 - Nunca & 14,3 & 14,3 & $\mathbf{0}$ \\
\hline 7 - Metade & 42,8 & 42,8 & $\mathbf{0}$ \\
\hline 8 - Lado direito & 57,1 & 28,6 & $\mathbf{- 2 8 , 5}$ \\
\hline 9 - Tam. Médio & 28,6 & 28,6 & $\mathbf{0}$ \\
\hline 10 - Menos & 28,6 & 85,7 & $\mathbf{5 7 , 1}$ \\
\hline 11 - Entre & 57,1 & 42,8 & $\mathbf{- 1 4 , 3}$ \\
\hline 12 - Logo & 71,4 & 57,1 & $\mathbf{- 1 4 , 3}$ \\
\hline 13 - Debaixo & 71,4 & 100 & $\mathbf{2 8 , 6}$ \\
\hline 14 - Muitas & 71,4 & 71,4 & $\mathbf{0}$ \\
\hline 15 - Agora & 71,4 & 71,4 & $\mathbf{0}$ \\
\hline
\end{tabular}

Por meio desta tabela, é possível observar que os maiores aumentos nos números de respostas corretas ocorreram nas questões referentes aos conceitos de “menos" (57,1 \% a mais de respostas corretas), “depois”, “em volta”, “centro” e “debaixo” (com 28,6 \% a mais de respostas cada). As questões correspondentes aos conceitos de “cedo", “entre” e "logo" obtiveram um decréscimo no número de respostas corretas (-14,3\%), assim como "lado direito” (-28,5\%), o que indica que, no pré-teste, alguns acertos tenham ocorrido por acaso.

Ao considerarmos as diferenças entre o pré e o pós-testes, observamos um pequeno aumento no número de respostas corretas, assim como um decréscimo no que se refere a alguns dos conceitos avaliados. A julgar por tais resultados, chegaremos à conclusão de que a atividade lúdica teve um efeito desprezível na formação de conceitos por crianças com paralisia cerebral. 
Contudo, torna-se difícil avaliar até que ponto tais dados refletem verdadeiramente a evolução das crianças no decorrer dos atendimentos, visto o grande número de incertezas, ao longo dos estudos de casos, no que se refere aos resultados dos testes. Algumas crianças acertaram itens no pré-teste e erraram no pós-teste, o que sugere acertos por acaso; outras responderam de maneira correta à questão, mas não pareciam dominar o conceito a ela referente em situações práticas; outras, ainda demonstraram dúvidas ao indicar a resposta que julgavam correta, o que sugere que o conceito estava em fase de desenvolvimento.

Por estes motivos, faz-se necessário relacionar os dados obtidos nos testes com as anotações do diário de campo, que permitem identificar os conceitos mais trabalhados com cada criança participante, no decorrer da pesquisa, uma vez que é razoável supor que o tempo de treinamento ou trabalho com cada conceito constitui uma variável crucial na aprendizagem de conceitos. A Tabela 6.34 apresenta os três conceitos mais trabalhados ${ }^{47}$ com cada criança e suas respectivas respostas nos testes de conceitos, bem como a diferença do número de acertos entre o pré e o póstestes.

\footnotetext{
${ }^{47}$ No caso de N., houve empate no que se refere ao terceiro conceito mais trabalhado; optou-se, portanto, pelo conceito que obteve uma resposta negativa no pré-teste e uma resposta positiva no pós-teste, demonstrando, assim, que houve um aprendizado no decorrer das sessões.
} 
Tabela 6.34 - Conceitos mais trabalhados, respostas das crianças nos testes e diferença do número de acertos.

\begin{tabular}{|c|c|c|c|c|c|}
\hline Sujeito & Conceito & \% de sessões & $\begin{array}{c}\text { Pré-teste } \\
\text { A }\end{array}$ & $\begin{array}{c}\text { Pós-teste } \\
\text { B }\end{array}$ & $\begin{array}{l}\text { Diferença do } \\
\text { no. de acertos } \\
\text { (B-A) }\end{array}$ \\
\hline \multirow[t]{3}{*}{$\mathrm{N}$. } & Debaixo & 62,5 & $\mathrm{E}$ & A & \multirow[t]{3}{*}{3} \\
\hline & Depois & 50 & $E$ & A & \\
\hline & Centro & 37,5 & $E$ & A & \\
\hline \multirow[t]{3}{*}{ F. } & Lado direito & 92,3 & A & A & \multirow[t]{3}{*}{1} \\
\hline & Menos & 76,9 & $\mathrm{E}$ & $\mathrm{A}$ & \\
\hline & Debaixo & 30,8 & A & A & \\
\hline \multirow[t]{3}{*}{ B. } & Debaixo & 57,1 & $E$ & $\mathrm{~A}$ & \multirow[t]{3}{*}{1} \\
\hline & Muitos & 28,6 & A? & $\mathrm{E}$ & \\
\hline & Depois & 28,6 & $\mathrm{E}$ & $E$ & \\
\hline \multirow[t]{3}{*}{ FR. } & Lado direito & 81,8 & A & A & \multirow[t]{3}{*}{1} \\
\hline & Centro & 63,3 & $\mathrm{E}$ & A & \\
\hline & Depois & 45,4 & $\mathrm{E}$ & $\mathrm{E}$ & \\
\hline \multirow[t]{3}{*}{ V. } & Tamanho médio & 100 & $E$ & $E$ & \multirow[t]{3}{*}{1} \\
\hline & Menos & 100 & $\mathrm{E}$ & $\mathrm{E}$ & \\
\hline & Depois & 80 & $\mathrm{E}$ & $\mathrm{A}$ & \\
\hline \multirow[t]{3}{*}{ E. } & Muitas & 91,7 & $\mathrm{E}$ & $\mathrm{A}$ & \multirow[t]{3}{*}{1} \\
\hline & Tamanho médio & 75 & $\mathrm{E}$ & $\mathrm{E}$ & \\
\hline & Depois & 66,7 & $\mathrm{~A}$ & A & \\
\hline \multirow[t]{3}{*}{ L. } & Em volta & 81,8 & $\mathrm{E}$ & $\mathrm{A}$ & \multirow[t]{3}{*}{2} \\
\hline & Menos & 63,6 & $\mathrm{~A}$ & $\mathrm{~A}$ & \\
\hline & Tamanho médio & 54,5 & $E$ & $\mathrm{~A}$ & \\
\hline
\end{tabular}

Conforme foi possível observar por meio dos resultados nos testes e pelo desempenho observado durante as brincadeiras, todas as crianças participantes da pesquisa aprenderam ao menos um dos conceitos mais trabalhados no decorrer das sessões, o que sugere que alguns outros conceitos não foram aprendidos devido ao pouco tempo destinado aos atendimentos.

N. parece ter desenvolvido, no transcorrer dos atendimentos, os conceitos de “debaixo" e “depois” (trabalhados em 62,5\% e 50\% das sessões, respectivamente); o acerto referente ao conceito “centro" (37,5\% das sessões) é duvidoso, visto que a criança indicou também uma opção errada. Além destas, a criança também acertou a questão referente ao conceito de “menos”, que foi pouco trabalhado (25\%); contudo, o fato de ter sido utilizado nas duas últimas sessões 
pode ter influenciado no resultado, o que pode indicar que este conceito estivesse em fase de aprendizado.

F., além de ter aprendido a utilizar o conceito de “menos” (76,9\%) e “mais” (71,4\%) em algumas situações, também adquiriu outras noções relacionadas ao domínio de quantidade, além de ter desenvolvido um pouco mais a noção de lateralidade e os conceitos a ela relacionados: “lado” (85,7\%), “lado direito” (92,3\%) e “lado esquerdo” (85,7\%). Também aprendeu alguns conceitos de tempo que não foram avaliados por meio dos testes.

B. acertou a questão referente ao conceito "debaixo”, o mais trabalhado no decorrer dos atendimentos (57,1\%), mas também desenvolveu os conceitos de "grande” (66,7\%) e "pequeno" (60\%), que não foram avaliados por meio do teste de conceitos.

FR. além de ter aprendido o conceito de "centro", um dos mais trabalhados nas sessões de brincadeiras (63,6\%), também parece ter aprendido os conceitos de "entre” (36,4\%) e "em volta” (27,3\%). Apesar de ter acertado, no pré-teste, as questões relacionadas aos conceitos de "menos" (45,4\%) e "lado direito” (81,8\%), parece ter evoluído na utilização destes em situações práticas e espontâneas.

V. aprendeu o conceito de “depois”, dentre os mais trabalhados nos atendimentos (80\%), mas também parece ter evoluído na aprendizagem dos conceitos de “menos” (100\%) e “em volta” (20\%).

E., além de ter aprendido o conceito de "muitas", o mais trabalhado durante a pesquisa (91,7\%), também acertou as questões referentes aos conceitos de “agora” e “menos”, trabalhados em um número menor de sessões (50 e 33,3\%, respectivamente).

L., por sua vez, parece ter desenvolvido os conceitos mais trabalhados, “em volta” (81,8\%) e “tamanho médio” (54,5\%), mas também acertou o conceito “centro” (45,4\%). 
Além da aprendizagem de conceitos, as sessões de brincadeiras também favoreceram outros aspectos do desenvolvimento das crianças participantes. Neste sentido, nos casos de N., FR., B., L. e V, os atendimentos favoreceram a realização de atividades bimanuais, visto que estas crianças usavam preferencialmente um membro superior, evitando o uso do membro mais afetado. Seus pais também foram orientados a estimular o uso de ambos os braços sem que seja necessário solicitar diretamente à criança ou brigar com ela, como alguns costumavam fazer.

B. passou a ter mais segurança durante as brincadeiras, diminuindo seu medo de cair; também passou a demonstrar maior atenção às brincadeiras e atividades.

As crianças que necessitavam de ajuda para a realização das ações, aos poucos conseguiram participar mais, havendo a possibilidade de reduzir o grau da assistência, o que indica que aprenderam os movimentos necessários para tais tarefas, bem como obtiveram uma melhora na coordenação motora.

FR., V. e E. apresentaram uma melhora significativa no que se refere ao comportamento durante os atendimentos. FR. passou a respeitar melhor os limites impostos pela pesquisadora, bem como a respeitar mais as regras das brincadeiras; também aprendeu a lidar melhor com as frustrações, aceitando quando perdia em algum jogo. V. aprendeu a respeitar as regras das brincadeiras e a esperar a sua vez de brincar. E. deixou de se comportar de maneira inadequada, modificando o modo de se relacionar com as terapeutas, o que também se refletiu na relação da criança com sua tia.

Esta criança, que no início apenas explorava os objetos e não respondia às intervenções da pesquisadora, passou a participar ativamente das atividades simbólicas, participando de acordo com os personagens propostos e se envolvendo em atividades com início, meio e fim. Além desta, todas as outras crianças tiveram um aumento em seu repertório lúdico, ou seja, aprenderam novas brincadeiras ou novas formas de utilizar os brinquedos já conhecidos. N. voltou a se 
interessar pelos brinquedos, visto que deixava de brincar para assistir à televisão. As famílias das crianças participantes também aprenderam novas formas de brincar com seus filhos. 


\section{CAPÍTULO 7}

\section{DISCUSSÃO}

Segundo Vygotsky (1998), no processo de desenvolvimento do ser humano ocorre uma interação entre os aspectos biológicos e culturais, de modo que os seus processos psíquicos elementares estão pautados no substrato neural, enquanto que suas funções mais complexas têm uma influência mais significativa do contexto sociocultural do qual faz parte. Desta afirmação podemos extrair duas reflexões. Primeira, é de se esperar que a criança com deficiência decorrente de uma lesão no sistema nervoso central apresente algumas dificuldades resultantes diretamente da lesão encefálica. Deste modo, quanto mais grave a lesão, maior seria o grau de dificuldade apresentada; este aspecto é ressaltado por Lamônica et al. (2003) e Pfeifer (1997), que encontraram correlações entre o grau de incapacidade e o desenvolvimento cognitivo da criança com paralisia cerebral. No que se refere às crianças da pesquisa, também pudemos observar uma relação entre o nível de comprometimento motor e o domínio de conceitos básicos: F. e FR., crianças que apresentavam o menor comprometimento, obtiveram os melhores resultados no pré-teste.

A dificuldade encontrada pelas crianças com maiores comprometimentos nos sugere as seguintes explicações: a extensão da lesão encefálica, que pode atingir também áreas responsáveis pelo funcionamento cognitivo e/ou a falta de experiências decorrente da incapacidade de explorar ativamente o ambiente. Não obstante, mesmo as crianças com graves comprometimentos motores conseguiram aprender ao menos um dos conceitos mais trabalhados na pesquisa, o que mostra que o atraso no desenvolvimento cognitivo pode também ter decorrido da falta de estimulação adequada. De modo semelhante, Carabetti, Leme e Prieto (2005) e Eagle 
(1985) observaram que, mesmo uma criança com graves comprometimentos motores, pode apresentar progressos no desenvolvimento cognitivo, quando adequadamente estimulada.

Desta forma, uma segunda reflexão que podemos fazer diz respeito ao fato de que a capacidade cognitiva não decorre simplesmente do substrato neural, mas também, ou principalmente, das condições concretas de vida de cada indivíduo. Por isso, a lesão encefálica simplesmente não é capaz de explicar a totalidade do desenvolvimento da criança com paralisia cerebral, visto que grande parte deste decorre das oportunidades que o meio social lhe oferece. Vygotsky (1983/1997) parece concordar com esta afirmação, pois declara que é no desenvolvimento cultural que se abre um caminho infinitamente maior de possibilidades para a compensação da deficiência.

Alguns outros autores reforçam esta idéia, afirmando que o desenvolvimento da criança com paralisia cerebral não é determinado apenas pela lesão neurológica ou pela dificuldade motora, mas pode variar de acordo com o ambiente no qual a criança vive, visto que este pode ou não fornecer condições adequadas (BRAGA, 1995; CARVALHO, 1998; CIASCA; MOURARIBEIRO; TABAQUIM, 2006; LORENS, 1974; MOTTA; TAKATORI, 2001; RAMM, 1988). A falta de oportunidades para brincar também é tida como um fator que limita o desenvolvimento da criança com deficiência (BLANCHE, 2002; MISSIUNA; POLLOCK, 1991; PENTEADO; SEABRA; BICUDO-PEREIRA, 1996).

Torna-se cada vez mais aceita esta concepção de que fatores ambientais e pessoais exercem forte influência sobre o desenvolvimento e a participação da pessoa com deficiência. A Organização Mundial da Saúde (OMS) vem realizando discussões neste sentido, passando a considerar que não há uma relação direta entre a deficiência e a limitação da funcionalidade. Deste modo, uma deficiência, dependendo do contexto no qual se insere, pode ou não gerar uma incapacidade. Tal concepção se reflete na Classificação Internacional de Funcionalidade, 
Incapacidade e Saúde (CIF), aprovada em 2001 pela Assembléia Mundial da Saúde. Esta classificação relaciona a funcionalidade e a incapacidade com o contexto físico e social, as percepções culturais, as atitudes em relação à deficiência, a disponibilidade de serviços e a existência de políticas públicas e de legislação específica (DINIZ; MEDEIROS; SQUINCA, 2007; FARIAS; BUCHALLA, 2005; ROCHA, 2006).

Não obstante tais considerações, ainda são poucas as pesquisas que investigam o impacto de fatores ambientais, tais como a estimulação por meio de brincadeiras, sobre o desenvolvimento da criança com seqüelas de paralisia cerebral. Na prática clínica, com muita freqüência, as dificuldades da criança com este tipo de deficiência são atribuídas a causas primárias, como decorrentes da lesão encefálica, desconsiderando-se que as dificuldades escolares e a própria deficiência mental podem também ser de origem secundária. A criança com uma deficiência motora, poderá encontrar dificuldades para explorar o seu próprio corpo e o seu ambiente, o que pode limitar o seu desenvolvimento em diversos aspectos (PERES, 2004); além disso, a falta de estimulação ambiental adequada também pode gerar déficits no desenvolvimento cognitivo (FERLAND, 2006).

Admitindo-se que o ambiente no qual a criança vive é de fundamental importância para seu desenvolvimento cognitivo, no seu estudo devemos considerar suas condições concretas de vida e suas relações sociais (PALANGANA, 2001; VYGOTSKY, 1998). Não podemos centrar-nos apenas na capacidade cognitiva que a criança com deficiência apresenta num determinado momento, mas devemos relacioná-la às suas condições reais de vida.

Nesta pesquisa, buscamos obter alguns dados que nos ajudassem a compreender o dia a dia das crianças participantes. Observamos que todas as crianças freqüentavam, além da escola, algum tipo de tratamento reabilitacional, sendo que N. e V. realizavam cinco tipos diferentes de tratamento. Apesar da importância deste tipo de atividade para o desenvolvimento da criança, é 
necessário levar em consideração que o excesso de tratamentos pode interferir de forma negativa no dia a dia da criança, visto que sobra pouco tempo para que ela participe de atividades familiares e tenha oportunidades de se engajar em brincadeiras livres com outras crianças (BLANCHE, 2002; FERLAND, 2006; MISSIUNA; POLLOCK, 1991).

N. era a única criança que não freqüentava a escola comum, tendo menos oportunidades para brincar com crianças sem deficiência. Esta criança, além de ter poucas oportunidades para brincar, também não demonstrava muito interesse por brinquedos, preferindo assistir à televisão. F. era a criança que parecia participar de uma maior variedade de brincadeiras, além de ter possibilidade de brincar com um maior número de crianças. B., apesar de brincar com sua irmã, permanecia muito passiva durante tais brincadeiras, de modo que, ao final da pesquisa, já não queria mais brincar com ela, preferindo brincar sozinha; devido ao déficit de atenção, percebeu-se que a criança tinha dificuldades em permanecer atenta até o final de uma mesma brincadeira. FR. não tinha irmãos e nem muitas oportunidades de brincar com outras crianças, fora do horário escolar; sua mãe relatou que ele não se mantinha concentrado em uma mesma brincadeira por muito tempo. V. participava de todas as atividades familiares e tinha oportunidades para brincar o dia inteiro. E. morava em uma casa com quintal e gostava de brincar com terra; brincava sozinho ou com os primos; no início da pesquisa, apresentava problemas de comportamento, dificultando seu relacionamento com outros adultos além de seus pais. L. costumava brincar com a irmã; só às vezes acompanhava sua família aos espaços da comunidade, parecendo ser excluída da maioria deles. Como foi possível observar, o tipo de relação com a família e as oportunidades para participar de brincadeiras livres variaram bastante de uma criança para outra.

Nos questionários, alguns dos pais relataram pouca variedade nos brinquedos utilizados pelas crianças, que brincavam apenas com carrinhos, bolas e bonecos. Poderíamos justificar tal constatação pelo fato de que todas as crianças participantes vinham de classes menos favorecidas 
da população, pois seus pais tinham um baixo nível de escolaridade. Acreditamos, contudo, que a desinformação seja um fator ainda mais limitante para a brincadeira da criança do que a sua condição econômica. Muitos dos brinquedos utilizados nesta pesquisa são de baixo custo $^{48}$ e podem ser facilmente adaptados, o que indica que há, na verdade, pouco conhecimento a respeito dos brinquedos que podem ser ofertados à criança com deficiência. Mesmo no caso de famílias de baixa renda, que não têm condições reais de adquirir brinquedos para os filhos, há a possibilidade de incluir objetos de uso doméstico nas brincadeiras das crianças (nesta pesquisa, por exemplo, foram utilizados rolos de papel, bacias, cestos, cones de costura, caixas de papelão, entre outros). Embora não tenha sido observado nos casos relatados, alguns pais de crianças com deficiência adquirem brinquedos inadequados para a idade, para os interesses ou para as possibilidades de seus filhos: alguns, por exemplo, compram apenas chocalhos e mordedores, apesar de a criança não ser mais um bebê. Percebe-se, assim, a necessidade de que os pais recebam orientações acerca de brinquedos que possam estimular o desenvolvimento de seus filhos.

Nesta pesquisa, tal como descrito por Carvalho (1998), também encontramos algumas barreiras para as brincadeiras das crianças participantes. Além da falta de acesso a brincadeiras variadas e da escassez de oportunidades para relacionar-se com outras crianças, a própria incapacidade motora pode ser um fator que limita as brincadeiras livres das crianças com deficiência. Todos os participantes desta pesquisa tinham dificuldades em realizar brincadeiras que implicassem em andar ou correr. Algumas crianças apresentavam dificuldades para realizar mudanças posturais (por exemplo, sentar-se e levantar-se sem auxílio), realizar atividades que exigissem o uso das duas mãos e/ou manipular objetos com independência.

\footnotetext{
${ }^{48} \mathrm{Na}$ seleção das brincadeiras para esta pesquisa, houve a exclusão de brinquedos de alto custo ou que não pudessem ser substituídos por materiais alternativos, visando facilitar o acesso das famílias aos mesmos, possibilitando a continuação, em casa, das brincadeiras aprendidas em terapia.
} 
Segundo Vygotsky (1934/2001), o desenvolvimento de conceitos espontâneos se dá por meio do contato da criança com os objetos e com as pessoas. Por exemplo, quando a criança coloca-se debaixo da mesa, em cima da cadeira, perto ou longe de algum objeto, ela experimenta com o próprio corpo diversas situações que auxiliam na formação de conceitos de espaço. Ela também experimenta as relações dos objetos entre si, empilhando cubos ou colocando uma bolinha dentro de uma garrafa. Estes conceitos também são nomeados pelos adultos ou parceiros mais experientes, quando estes pedem para que a criança saia debaixo da mesa ou pegue uma bola debaixo do sofá, por exemplo. Desta forma, tal como descrito por Hartley (1971), em momentos de brincadeira ou em situações cotidianas, a criança vai formando seus conceitos espontâneos de quantidade, tempo, espaço e velocidade, fundamentais para o seu pensamento. Contudo, tal como descrito por Finnie (1980) e Peres (2004), a criança com deficiência pode ter pouca chance de vivenciar este tipo de situação, pois a incapacidade motora dificulta a exploração ativa do ambiente - ela pode precisar de ajuda para isso.

Além da dificuldade na manipulação de objetos e da restrição na participação de brincadeiras, a criança com paralisia cerebral muitas vezes não participa de atividades familiares como uma criança sem deficiência. Estas crianças exploram ativamente o ambiente, abrem armários e gavetas, auxiliam na arrumação dos brinquedos, acompanham seus pais por todos os ambientes da casa, observando de onde os objetos são retirados e onde são guardados. As crianças vêem como as coisas são naturalmente categorizadas dentro de casa: a comida é guardada em um armário, as panelas em outro; os bonecos são colocados em uma caixa, os lápis em outra. Este tipo de atividade de discriminação e classificação faz com que a criança aprenda, de forma espontânea, a categorizar e a formar conceitos.

Ao contrário, a criança com deficiência, em muitos casos, permanece passiva, apenas recebendo os objetos necessários para seus cuidados pessoais. A comida simplesmente surge na 
sua frente, sua roupa é sempre escolhida por outra pessoa; às vezes não tem chances, nem mesmo, de escolher com que brinquedo quer brincar. Estas crianças podem não ter oportunidades de ver como as coisas são arrumadas nos armários, na geladeira, nos guarda-roupas e nem sempre contam com um suporte familiar que seja estimulante. Para Jurdi (2001), muitos familiares têm dificuldades em estabelecer trocas com a criança com deficiência porque não nutrem expectativas positivas acerca do seu desenvolvimento. Na prática clínica, encontramos até mesmo pais que não conversam com os seus filhos; quando a criança possui dificuldades para falar e interagir com as pessoas, alguns pais ficam desestimulados a falar com a criança, pois pensam que ela não compreende nada.

Contudo, a comunicação é fundamental para o desenvolvimento de qualquer criança, pois é por meio de relações sociais concretas, tais como aquelas estabelecidas em momentos de brincadeiras e atividades cotidianas, que um indivíduo se apropria do conhecimento. O adulto é quem ajuda a criança a estabelecer relações entre os objetos e a focar a atenção no que é essencial, desenvolvendo a atenção seletiva (PALANGANA, 2001; VYGOTSKY, 1998), que é fundamental para o processo de formação de conceitos. De acordo com Prado (1991), o adulto é quem vai explicitando para as crianças os significados embutidos nas relações humanas, nos objetos e nas palavras. Deste modo, quando ocorre a falta de comunicação entre a criança com deficiência e seus cuidadores, o desenvolvimento cognitivo da criança pode ser prejudicado.

A falta de oportunidades para estabelecer relações sociais saudáveis, brincar, explorar o ambiente e participar ativamente das atividades familiares, limitando a formação de conceitos espontâneos, pode acarretar em dificuldades na aprendizagem escolar, visto que, tal como descrito por Vygotsky (1934/2001), a aprendizagem de conceitos científicos ocorre por mediação dos conceitos espontâneos. Além disso, as crianças com deficiência, em alguns casos, têm os seus 
objetivos educacionais e terapêuticos subestimados, o que reduz ainda mais suas possibilidades de desenvolvimento.

De acordo com Vygotsky (1983/1997), muitos educadores limitam a priori o aprendizado da criança com deficiência, por acreditar que ela não poderá aprender nada além; ao contrário, a educação da criança com deficiência deve ter as mesmas metas da educação da criança sem deficiência, mesmo que sejam necessários recursos especiais. Tal como criticado por este autor, observamos freqüentemente, no atendimento de crianças com deficiência, que algumas escolas especiais ou regulares limitam a priori as suas possibilidades de aprendizagem. Em muitos casos, ouvimos relatos de que esta criança, apesar de estar em uma sala de aula regular, realiza atividades completamente diferentes das realizadas pelo restante dos colegas. Algumas mães mencionam, por exemplo, que seus filhos colorem desenhos, enquanto que as demais crianças trabalham com letras ou números. Se a criança com deficiência não tiver oportunidades de realizar tais atividades, jamais conseguirá evoluir na aprendizagem deste conteúdo.

Jurdi (2004) também observou situações semelhantes, salientando que, sem uma política educacional realmente comprometida com a inclusão, as crianças com deficiência podem freqüentar os mesmos espaços físicos, sem ter acesso aos mesmos conhecimentos. Apesar de não termos dados concretos acerca da educação das crianças participantes da pesquisa, devemos levar em consideração que o simples fato de freqüentar uma escola comum ${ }^{49}$ não significa que os objetivos educacionais sejam os mesmos para todas as crianças.

Deste modo, é possível refletir sobre as diferentes condições concretas da vida da criança com deficiência que podem interagir para dificultar seu desenvolvimento cognitivo: a própria incapacidade motora, que dificulta a exploração do meio; a redução da comunicação com seus cuidadores; a falta de oportunidades para brincar e participar de tarefas cotidianas; condições de

\footnotetext{
${ }^{49}$ Com exceção de N., todas as demais crianças desta pesquisa freqüentavam escolas regulares.
} 
ensino inadequadamente organizadas. Assim, apesar de sabermos que a criança com paralisia cerebral possa ter uma deficiência mental de origem orgânica, devemos observar se outros fatores não estão influenciando em seu desenvolvimento cognitivo. Da mesma forma, devemos averiguar se um atraso no desenvolvimento conceitual não é decorrente da privação de experiências, de modo que este tipo de atraso não seja inquestionavelmente atribuído a um déficit cognitivo.

Ao compararmos os resultados do pré-teste com os resultados obtidos por crianças sem deficiência, percebemos que, com exceção de F., as demais crianças da pesquisa apresentavam um atraso no desenvolvimento dos conceitos avaliados. Não podemos, contudo, nos acomodar na crença de que este atraso já era esperado, por se tratar de crianças com deficiência. Este tipo de pensamento é que nos leva a limitar "aprioristicamente” as possibilidades de desenvolvimento destas crianças. Embora não possamos excluir a possibilidade de que algum dos participantes apresentasse algum nível de deficiência mental de origem orgânica, podemos afirmar, sim, que todas as crianças, com exceção de B., mostraram-se extremamente atentas, participativas e interessadas nas atividades, parecendo compreender tudo que era dito pela pesquisadora; também respondiam satisfatoriamente a todas as suas solicitações. Também não podemos justificar o mau desempenho no teste pela alegação de que tais crianças não conseguem aprender, pois, como observado no final da pesquisa, todas as crianças aprenderam ao menos um dos conceitos mais trabalhados. Como explicar, então, que o seu desempenho no pré-teste tenha sido tão inferior ao desempenho de crianças três anos mais novas? Se, com pouco tempo de intervenção ${ }^{50}$, as crianças com paralisia cerebral se mostraram capazes de aprender tais conceitos, podemos nos perguntar se o fato de não os terem aprendido anteriormente não seria decorrente da falta de oportunidades para isso.

\footnotetext{
${ }^{50}$ As crianças participaram de uma média de 13,3 atendimentos; se considerarmos que o primeiro e o último atendimentos foram destinados à aplicação do teste, observaremos que os conceitos foram trabalhados durante apenas 10 atendimentos (em média), com cerca de uma hora cada.
} 
Deste modo, não podemos encarar as diferenças entre os resultados simplesmente como esperadas, nem considerar as dificuldades destas crianças como meramente decorrentes de sua lesão encefálica. Ao contrário, devemos nos questionar se o déficit na formação de conceitos não é resultante de um déficit nos programas de reabilitação e no sistema de ensino. Estas crianças podem necessitar de meios especiais, de maior estímulo por parte dos adultos, ou podem necessitar de mais tempo. Até que ponto elas poderão chegar - não nos cabe definir. O que podemos afirmar é que elas se mostraram capazes de aprender, o que indica que ao menos parte do atraso no desenvolvimento conceitual pode ter sido fruto da falta de estimulação adequada.

A visão teórica, ao afirmar que o desenvolvimento conceitual ocorre em momentos diferentes para diferentes domínios de conhecimento (KEIL, 1989), também parece evidenciar que os conceitos de cada pessoa estão fortemente relacionados ao tipo de ambiente em que vive. Uma criança que tem contato com seus familiares provavelmente desenvolverá conceitos de parentesco mais precocemente que uma criança que convive apenas com seus pais e irmãos. Deste modo, podemos deduzir que o desenvolvimento de conceitos, sejam eles espontâneos ou científicos, dependerá das oportunidades que o indivíduo tem, ao longo de sua vida, de entrar em contato com tais conhecimentos. Crianças com deficiência que tiverem poucas oportunidades de vivenciar atividades comuns às demais crianças, certamente apresentarão atrasos no desenvolvimento de conceitos relacionados a tais experiências.

Por outro lado, Aguiar (2004) e Penazzo (1994) comprovaram que o fornecimento de oportunidades para experimentar atividades motoras e lúdicas favorece o desenvolvimento de conceitos, mesmo em crianças com deficiência mental, as quais, de acordo com Jurdi (2004), costumam ter suas capacidades de aprendizagem subestimadas.

Nesta pesquisa, interessava-nos saber se o oferecimento de oportunidades para brincar poderia colaborar, de forma indireta e espontânea, para o desenvolvimento dos conceitos básicos 
pelas crianças com seqüelas de paralisia cerebral. Por conceitos básicos podemos compreender aqueles conceitos espontâneos, formados no contato direto da criança com os objetos, pessoas e situações. Por este motivo, neste estudo, os conceitos não eram definidos nem sistematizados, mas trabalhados por meio da experiência espontânea da criança, buscando enriquecer suas vivências lúdicas. Nestes momentos de brincadeira, a pesquisadora conversava com a criança, nomeando os objetos, relatando o que ocorria, fazendo perguntas e sugerindo soluções; pois, tal como descrito por Vygotsky (1934/2001), é por meio da linguagem que a criança aprende sobre as coisas do mundo e aprende a ordenar seu pensamento.

A abordagem terapêutica utilizada nesta pesquisa é baseada em discussões de Blanche (2002) e Missiuna e Pollock (1991), defensores de que a brincadeira deve ser o objetivo da intervenção do terapeuta ocupacional, e não apenas um instrumento para atingir objetivos específicos. O Modelo Lúdico ${ }^{51}$, contudo, veio corroborar a abordagem aqui adotada. Este modelo, que sistematiza o uso da brincadeira como objetivo e instrumento da intervenção do terapeuta ocupacional, não é, segundo a própria autora, totalmente inédito, visto que muitos profissionais aplicam intuitivamente métodos semelhantes ao apresentado (FERLAND, 2006). Assim, é possível observar muitas semelhanças entre o Modelo Lúdico e os métodos de intervenção aqui empregados.

Para Ferland (2006), a brincadeira deve ser, ao mesmo tempo, um instrumento de intervenção para atingir objetivos terapêuticos e o próprio objetivo da intervenção do terapeuta ocupacional. Este deve favorecer o engajamento da criança em brincadeiras espontâneas, visando prevenir incapacidades secundárias e estimular seu desenvolvimento integral. Nesta pesquisa, as crianças eram estimuladas a brincar da maneira a mais autônoma possível, de modo que o

\footnotetext{
${ }^{51}$ O Modelo Lúdico foi proposto por Francine Ferland em um livro lançado no Brasil apenas em 2006. Deste modo, a autora deste trabalho só teve acesso ao modelo após o início da pesquisa de campo, quando a abordagem aqui utilizada já havia sido desenvolvida com base nas discussões de Blanche (2002) e Missiuna e Pollock (1991).
} 
objetivo de desenvolver os conceitos básicos aparecia sempre como um pano de fundo, presente apenas na mente da pesquisadora, não da criança. O único objetivo da criança era brincar; assim, não era a criança quem deveria se adaptar ao que a pesquisadora queria, mas era esta quem deveria adaptar seus objetivos terapêuticos à brincadeira escolhida pela criança.

Bach-y-Rita (1981) e Johansson (2004) afirmam que a atividade deve ser significativa para que promova o aprendizado. Podemos deduzir, então, que a aprendizagem da criança pode ser fomentada por meio de atividades lúdicas que sejam significativas para ela. Por isso, ela deve ter a possibilidade de escolher a brincadeira que quer realizar. Esta escolha também é importante para estimular a autonomia da criança, que, em muitos casos, tem poucas chances de escolher o que quer fazer (FERLAND, 2006; ROCHA, 2006). Mesmo que seja dependente para realizar a atividade, a criança pode ser autônoma para decidir o que quer fazer e para guiar a brincadeira.

Assim, no início dos atendimentos, tal como descrito no Modelo Lúdico, a criança era solicitada a escolher uma dentre algumas opções de brincadeiras disponíveis. As brincadeiras oferecidas foram pré-selecionadas, por serem consideradas acessíveis às crianças com deficiência e por terem o potencial de favorecer o desenvolvimento dos conceitos em tela. Blanche (2002) também parece defender este tipo de conduta, ao afirmar que os brinquedos devem ser escolhidos tanto pelos objetivos do terapeuta quanto pelos interesses da criança. Em cada atendimento, a pesquisadora oferecia três ou quatro opções de brincadeiras pré-selecionadas; a criança também tinha a liberdade de não aceitar nenhuma delas e sugerir um outro tipo de brincadeira. Este fato, porém, ocorreu raramente, pois, na maioria das vezes, as crianças se interessaram por algum dos brinquedos oferecidos. FR. foi a única criança que pediu por outro brinquedo além dos oferecidos pela pesquisadora. F., por outro lado, escolheu previamente a brincadeira que gostaria de realizar em algumas sessões, decisão esta que foi respeitada pela pesquisadora. 
Para Blanche (2002) e Ferland (2006), as alterações motoras e cognitivas que podem dificultar a ação da criança não são fatores impeditivos para que ela desenvolva atitude lúdica e motivação para brincar. Esta característica foi também observada nas crianças da pesquisa, que demonstraram, em todos os atendimentos, o interesse em desenvolver as atividades lúdicas. Mesmo N. que, segundo sua mãe, não se interessava mais por brincadeiras, demonstrou motivação e atitude lúdica durante as sessões, o que se refletiu no seu comportamento em casa, pois voltou a se interessar pelos brinquedos que possuía. O desinteresse apresentado previamente pela criança pode ser decorrente de uma estimulação insuficiente no que diz respeito às atividades lúdicas, seja por falta de companheiros para brincar, por falta de brincadeiras de seu interesse, ou por dificuldades de se engajar nas atividades sem uma ajuda adequada; ressalta-se, assim, a importância das orientações aos cuidadores. Acreditamos que sua mãe tenha tido um papel primordial neste processo, pois esta percebeu que seu filho era capaz de se engajar em diversas brincadeiras, aprendeu como auxiliar seu filho durante as mesmas e foi orientada a permitir que a criança escolhesse, no dia a dia, o brinquedo que gostaria de utilizar, o que não costumava fazer anteriormente.

Neste trabalho, durante as brincadeiras, a pesquisadora sempre verbalizava o que estava sendo feito e nomeava os conceitos relacionados a cada situação. Também fazia alguns comentários ou perguntas, chamando a atenção da criança para os conceitos em tela. Sempre que possível e pertinente à brincadeira, eram inseridos, de forma natural, alguns itens que favorecessem a inclusão de algum conceito específico. Por exemplo, ao brincarem de pescar os pequenos peixes carimbados, a pesquisadora também desenhava peixes médios e grandes, para que estes conceitos pudessem ser trabalhados. Ferland (2006) também considera possível este tipo de intervenção, pois, para ela, além dos benefícios decorrentes da brincadeira por si só, o 
terapeuta também pode incluir alguns elementos ou personagens que favoreçam o desenvolvimento de alguma habilidade específica.

Para esta autora, apesar da brincadeira ser o foco da intervenção, a terapia não deve ocorrer apenas nos momentos lúdicos, mas desde a chegada até a saída da criança. De maneira similar, nesta pesquisa, o processo de formação de conceitos não era trabalhado apenas na brincadeira em si, mas também nos momentos de escolher e de guardar os brinquedos. Após escolher o brinquedo que desejava, a criança ajudava a guardar, debaixo do tablado ou dentro do armário, aqueles brinquedos que não desejava. Ao guardar os brinquedos utilizados em cada sessão, a criança também ajudava a organizá-los, colocando um tipo de brinquedo em um local e outro tipo em outro, separando, por exemplo, as bolas grandes das pequenas, ou separando as casinhas dos bonecos. Este tipo de atividade, na qual a criança é solicitada a discriminar e classificar os objetos, também favorece o processo de formação de conceitos, no qual é fundamental a capacidade de discriminar atributos e incluir objetos em classes.

Nos momentos de brincadeiras, tal como descrito por Ferland (2006), a pesquisadora brincava com a criança, envolvendo-se na situação lúdica; além disso, buscava enriquecer a atividade, sugerindo situações novas e aumentando o repertório de brincadeiras da criança. Segundo esta autora, também é papel do terapeuta colocar os meios técnicos a serviço da criança, tais como adaptações e manuseios, que devem ser empregados com sutileza e de maneira lúdica. De maneira similar, nesta pesquisa, além de alguns recursos utilizados para o posicionamento adequado da criança, a pesquisadora também auxiliava, quando necessário, na manipulação dos objetos. Por exemplo, ao brincar com V., a pesquisadora se colocava na "equipe” da criança, contra o pai ou a estagiária, aproveitando-se deste pretexto para ajudar a criança a coordenar seus movimentos. 
Além da ajuda ofertada nos momentos de brincadeiras, a pesquisadora também buscava, sempre que possível, adaptar os brinquedos às dificuldades da criança, tal como descrito por Blanche (2002) e Erhardt e Merrill (2002). Não obstante, quando a criança apresentava alguma dificuldade na execução da atividade, a pesquisadora modificava as regras para todos os participantes. Por exemplo, ao brincarem de corrida de carrinhos, FR. apresentou dificuldades para puxar o cordão de seu carrinho com ambas as mãos; então, a pesquisadora estabeleceu a regra de que ela também só poderia puxar seu carrinho com uma das mãos.

Ferland (2006) afirma que, apesar de ajudar a criança, o terapeuta deve sempre estimular que ela tome iniciativas e encontre soluções; também não deve evitar todas as frustrações, visto que estas fazem parte do desenvolvimento de qualquer criança. No decorrer desta pesquisa, foi possível perceber que o terapeuta deve manter-se atento à sua própria conduta, pois, na tentativa de manter o interesse da criança na brincadeira, corre o risco de limitar as oportunidades para que ela tome suas próprias decisões e supere suas frustrações. Foi possível notar a necessidade de se manter o equilíbrio entre a oferta de ajuda e a liberdade para que a criança tente agir sozinha. Em alguns momentos, pode ser preciso que o terapeuta auxilie a criança na manipulação dos objetos, ou facilite para que ela tenha oportunidade de ganhar na brincadeira (pois, devemos levar em consideração que não podemos competir de igual para igual com uma criança), mas não devemos fazer com que a criança ganhe sempre, pois saber lidar com a derrota também faz parte do processo de desenvolvimento. Tal condição foi observada nos atendimentos de FR. e de V. que, no início, não aceitavam perder no jogo, mas foram aos poucos aprendendo a lidar de forma mais natural com este tipo de situação.

Nos momentos de brincadeira, a pesquisadora se colocava no mesmo nível da criança, ou seja, ambas se revezavam no comando da atividade, de modo que todas as decisões e modificações eram feitas em comum acordo. No caso de B., contudo, foi necessário que a 
pesquisadora assumisse um papel mais diretivo, visto que a criança desviava a atenção facilmente quando solicitada a agir com maior independência. Este tipo de conduta também é considerado por Blanche (2002) e por Ferland (2006), que observaram a necessidade de que o terapeuta assuma uma postura mais ativa nos casos de crianças que apresentam déficits no desenvolvimento cognitivo. Ao lidarmos com crianças que apresentam dificuldades na comunicação, também temos a tendência de assumir um papel mais ativo. Contudo, precisamos estar atentos para a necessidade de aguardarmos por suas respostas e iniciativas.

Durante os atendimentos, as crianças eram estimuladas a tomar decisões e, sempre que possível, suas iniciativas eram respeitadas e seguidas. Porém, a pesquisadora estabelecia alguns acordos com a criança que deveriam ser também respeitados. Como exemplo destes acordos, podemos citar o momento da escolha dos brinquedos: a criança era solicitada a escolher uma brincadeira para cada dia de atendimento e a mesma deveria ser realizada até o final. Ela poderia, assim como a pesquisadora, propor algumas modificações ou a inclusão de um outro brinquedo que enriquecesse a brincadeira, mas esta não poderia ser completamente alterada. Por exemplo, a criança poderia solicitar a inclusão de bonecos e carrinhos na brincadeira de construir castelos, para que fizessem uma cidade, contudo, uma vez escolhida a brincadeira de montar castelos, não era permitido que a criança interrompesse esta atividade para brincar com o jogo da memória. Esta atitude foi adotada porque, tal como observado nos questionários respondidos pelos pais, algumas crianças tinham dificuldades de se concentrar em uma mesma brincadeira. Visto que a sala de atendimentos geralmente apresenta diferentes brinquedos, este tipo de comportamento seria reforçado se fosse permitido que a criança brincasse com tudo o que quisesse. Além disso, se a criança ficasse mudando de atividade a todo o momento, acabaria por explorar superficialmente vários objetos e não teria a possibilidade de se engajar em todo o processo da brincadeira. A mudança completa da brincadeira foi permitida em poucas situações, quando a 
pesquisadora percebia que a atividade escolhida já havia esgotado todas as suas potencialidades, ou quando a criança havia feito a escolha de um brinquedo inadequado para seus interesses. Quando ela apresentava dificuldades para a manipulação do brinquedo, mas demonstrava interesse pelo mesmo, este era mantido, sendo realizadas adaptações nos objetos ou nos procedimentos.

Além de não permitir que a criança realizasse diferentes brincadeiras em uma mesma sessão, a pesquisadora também não admitia comportamentos inadequados ou desrespeitosos. Desta forma, estimular a liberdade da criança na brincadeira não implica na perda da autoridade do terapeuta. Sempre que a criança apresentava um comportamento inadequado, a pesquisadora conversava e alertava para o fato de que, se o comportamento persistisse, a brincadeira seria interrompida.

Este tipo de situação ocorreu apenas com FR. e E., no início da pesquisa. Observou-se que, com o decorrer das sessões, estas duas crianças apresentaram melhoras no comportamento, o que foi mais marcante no caso de E, que apresentava dificuldades em relacionar-se com pessoas do seu convívio. Nos primeiros atendimentos, esta criança também teve uma atitude agressiva perante a pesquisadora; aos poucos, contudo, E. foi deixando de agir desta forma para demonstrar uma atitude carinhosa e respeitosa, a qual se refletiu também no seu relacionamento com a tia. Percebeu-se que a modificação das relações de poder propiciadas pela brincadeira possibilitou o estabelecimento de um vínculo afetivo com a criança. Esta teve oportunidades para expressar suas opiniões, tomar iniciativas, escolher o que queria; também pôde assumir o comando em alguns momentos, obtendo um maior controle da situação. Ao brincar de restaurante, ora a criança era o chefe que deveria ser obedecido, ora era o ajudante que deveria obedecer, possibilitando uma inversão nas relações de poder. Além disso, os comportamentos adequados da criança passaram a ser salientados e valorizados. 
Neste processo, a criança percebeu que é possível relacionar-se de uma maneira distinta daquela a qual estava habituada. Visto que é por meio das relações sociais que a criança apreende o mundo (PALANGANA, 2001; VYGOTSKY, 1998), o tipo de relacionamento estabelecido entre a criança e as pessoas que a cercam é de fundamental importância, pois pode favorecer ou prejudicar o processo de aquisição do conhecimento.

No caso de FR., acreditamos que a possibilidade de participar de jogos com regras, somada à atitude da pesquisadora, tenha favorecido a melhora comportamental observada ao longo das sessões, visto que a participação neste tipo de atividade possibilita que a criança aprenda a respeitar regras e a conviver socialmente (CARVALHO, 1998; FERLAND, 2006; LA TAILLE, 1992; PIAGET, 1945/1975).

E. também apresentou melhora no que se refere à qualidade de sua participação nas brincadeiras: no início, a criança apenas explorava os brinquedos, mas, com o decorrer dos atendimentos, passou a participar de brincadeiras com começo, meio e fim, engajando-se nas situações imaginárias. De acordo com Kishimoto (1996) e Vygotsky (1976, 1998), todas as atividades lúdicas têm regras que determinam o seu funcionamento; a diferença é que os jogos possuem regras explícitas, enquanto que as brincadeiras possuem regras implícitas. Por este motivo, mesmo durante brincadeiras que envolviam o simbolismo, a pesquisadora procurava manter uma lógica nas ações realizadas. Por exemplo, ao brincarem de restaurante, a pesquisadora sempre procurava inserir algum sentido nas ações de E.: se estavam fazendo uma lingüiça e a criança a jogava em uma bacia com outros pedaços de massa, a pesquisadora perguntava se ele estaria fazendo uma macarronada. Aos poucos, a criança foi percebendo a seqüência da brincadeira e passou a contribuir ativamente para o estabelecimento de sentido para as suas ações. 
V. também apresentou melhora neste sentido, passando a perceber a seqüência das brincadeiras. Esta melhora pode ser decorrente do fato de que a pesquisadora estimulava a participação da criança em todas as etapas das atividades, evitando que estas fossem ignoradas ou suprimidas. Por exemplo, ao brincarem de pescaria, V. apenas pegava um peixe e queria devolvêlo à bacia com água; contudo, a pesquisadora explicava que eles estavam competindo e que, se a criança devolvesse seus peixes, seu padrasto ganharia a competição. Esta criança, aos poucos, passou a perceber e a respeitar as regras do jogo, interessando-se, inclusive, pelo momento da contagem dos peixes.

Muitos autores referem que a brincadeira beneficia o desenvolvimento da criança em diversos aspectos: constitui-se num meio de apropriação da realidade, estimulando a descoberta de si e do mundo; favorece o desenvolvimento do simbolismo, da imaginação, do saber-fazer, da linguagem e da coordenação motora; possibilita a apreensão do significado dos objetos; beneficia a relação com as pessoas e o respeito às regras; favorece o desenvolvimento do autocontrole, da capacidade de adaptação, da tomada de decisões e da autonomia; ensina a criança a lidar com a frustração e o fracasso (BRUNER, 1976; CARVALHO, 1998; FERLAND, 2006; KISHIMOTO, 1996; 2002; PRADO, 1991; QUEIROZ E MELO, 2004; SCHAAF, 1990; VYGOTSKY, 1976, 1998). Algumas pesquisas também mostraram os benefícios que a brincadeira traz para o desenvolvimento das crianças com paralisia cerebral (LORENZINI, 1999; PERES, 2004; SPARLING; WALKER; SINGDAHLSEN, 1984).

Para Ferland (2006), às vezes não é necessária muita intervenção para que o terapeuta atinja seus objetivos, pois o simples fato de brincar já estimula o desenvolvimento da criança. Nesta pesquisa, também observamos o desenvolvimento da criança em vários aspectos além da aprendizagem de alguns dos conceitos mais trabalhados. Algumas crianças, conforme salientado 
anteriormente, apresentaram melhora no comportamento e na participação nas brincadeiras, outras desenvolveram a coordenação motora, a atenção e o uso das duas mãos.

B., além de demonstrar uma atitude mais ativa nas brincadeiras em casa, também passou a falar sozinha durante as mesmas. Esta criança, apesar de conseguir falar, comunicava-se apenas ocasionalmente, por meio de frases curtas; sua mãe relatou que, antes do início da pesquisa, nunca havia observado a criança falando durante suas brincadeiras. Nas sessões, a pesquisadora conversava o tempo inteiro com a criança, nomeando o que era feito, fazendo perguntas e dando sugestões. A partir dos relatos da mãe de B., percebemos que o fato de a pesquisadora utilizar-se da fala para acompanhar as ações da criança fez com que ela desenvolvesse algo semelhante à linguagem egocêntrica, tal como descrita por Vygotsky (1934/2001).

Este fato nos trouxe diversos questionamentos sobre as crianças com paralisia cerebral que não conseguem falar, mas que apresentam a audição preservada. Estas crianças desenvolvem a fala interior e o pensamento verbal? Como ocorre este desenvolvimento? Será possível que a fala do adulto, acompanhando as ações da criança, favoreça o desenvolvimento da fala interior na criança com paralisia cerebral?

Sabemos que as respostas para este tipo de indagação são difíceis de serem encontradas. Afinal, como investigar o desenvolvimento da fala egocêntrica e da linguagem interior em crianças que não falam? Contudo, os relatos da mãe de B. dão pistas para refletirmos sobre este assunto: se esta criança passou a apresentar a linguagem egocêntrica, imitando o que a pesquisadora fazia durante os atendimentos semanais, podemos considerar a possibilidade de que uma outra pessoa sirva de mediadora para a constituição da linguagem interior da criança, fazendo o papel da fala egocêntrica. Este poderia constituir-se num caminho compensatório para o desenvolvimento da criança com deficiência. Diante desta hipótese, tornam-se ainda mais 
importantes as orientações aos pais das crianças com deficiência quanto à necessidade de falarem e brincarem com seus filhos.

Mais uma vez percebemos que, embora o meio social seja fundamental para o desenvolvimento de todas as crianças, este se torna ainda mais importante no caso de uma criança com deficiência. Sabe-se que o adulto tem o papel de facilitar a brincadeira das crianças, propiciando tempo e espaço para o brincar, favorecendo o acesso a objetos que possam ser utilizados nas brincadeiras, auxiliando na resolução de problemas e enriquecendo a experiência lúdica (BLANCHE, 2002; BRUNER, 1986; PIERRI; KUDO, 1994). No caso da criança com incapacidades motoras, além deste tipo de facilitação, pode haver a necessidade de ajuda na execução das ações, para que ela tenha a oportunidade de descobrir e aprender (ZERBINATO; MAKITA; ZERLOTI, 2003). A criança pode direcionar a tarefa, escolhendo o que e como fazer, enquanto o adulto a ajuda na execução da mesma (BRAGA, 1995).

Se considerarmos que a realização de atividades com o auxílio de um adulto favorece o desenvolvimento da criança, veremos a importância deste tipo de atividade assistida para a criança com deficiência. Neste trabalho, foi possível perceber que a pesquisadora pôde diminuir o grau de assistência nas tarefas, o que demonstra que as ações realizadas com ajuda puderam ser aprendidas pela criança. Este fato nos remete ao conceito de zona de desenvolvimento proximal (VYGOTSKY, 1998, 1934/2001), que, segundo Braga (1995), tem importantes repercussões no tratamento da criança com deficiência.

A noção de zona de desenvolvimento proximal também é importante ao pensarmos no processo de aprendizagem de conceitos. Para que esta aprendizagem seja significativa, devemos partir do nível de desenvolvimento no qual a criança se encontra, estimulando-a, por meio de ações partilhadas, a avançar em seu nível de desenvolvimento, passando a fazer com maior independência o que conseguia fazer apenas com ajuda. Neste sentido, buscamos identificar as 
dificuldades de cada criança participante e estimulá-la a progredir a partir dos conceitos já conhecidos. Nos primeiros atendimentos, por exemplo, observamos que B. não dominava os conceitos de "pequeno" e "grande". Assim sendo, optamos por estimular a aprendizagem destes conceitos antes de trabalharmos com o conceito de "tamanho médio", o que facilitou, posteriormente, a compreensão deste.

Porém, devido ao pouco tempo disponível para os atendimentos, não foi possível trabalhar suficientemente este último conceito, impossibilitando que a criança atingisse seu domínio até o final da pesquisa. Assim, embora algumas crianças tenham acertado, no pós-teste, questões referentes a conceitos pouco trabalhados, a aprendizagem parece ter ocorrido, principalmente, em relação aos conceitos mais trabalhados durante as sessões de brincadeiras. Este dado sugere que o tempo de treinamento é um fator crucial no desenvolvimento de conceitos básicos por crianças com paralisia cerebral. Acreditamos, portanto, que a aprendizagem de conceitos tenha sido limitada pelo pouco espaço de tempo destinado às sessões. Algumas crianças também faltaram a alguns atendimentos, o que limitou ainda mais o tempo destinado para as brincadeiras.

Por outro lado, conforme mencionado anteriormente, outros conceitos que não foram avaliados também foram incluídos nas atividades. Esta inclusão ocorreu principalmente pelo fato de que muitos dos conceitos trabalhados são do tipo relacional, que só adquirem sentido se considerarmos sua relação com outros conceitos. Como no exemplo anterior, para que a criança pudesse apreender o conceito de “tamanho médio”, era necessário que compreendesse sua relação com os conceitos de "pequeno" e "grande". O desenvolvimento deste tipo de conceito também chama a atenção para a importância do contato da criança com os objetos do ambiente, quer percebendo seu próprio corpo em relação a eles, quer observando as relações dos objetos entre si. Ou seja, a criança percebe o tamanho de seu próprio corpo em relação aos objetos e pessoas 
presentes em seu meio, observando que é maior que alguns e menor que outros; os adultos também chamam a atenção da criança para tais diferenças, mostrando-lhe que alguns objetos são grandes e outros pequenos. O mesmo ocorre na aprendizagem dos conceitos básicos de tempo e espaço, na qual as experiências cotidianas e lúdicas são fundamentais (HARTLEY, 1971).

As observações realizadas no decorrer dos atendimentos e registradas no diário de campo possibilitaram perceber que as crianças aprenderam muitos destes outros conceitos que, embora não fizessem parte da pesquisa, foram utilizados nas brincadeiras. Os dados do diário de campo também serviram para respaldar as informações obtidas por meio do teste de conceitos. Por exemplo, no caso de F., embora sua mãe tenha dito que a criança não apresentava dificuldades com os números, esta errou a questão referente ao conceito “menos”, no pré-teste. Também foi observado, no início dos atendimentos, que F. não dominava outros conceitos do domínio de quantidade, não tendo, nem mesmo, uma noção de número bem estabelecida. Esta incongruência de dados pode ser associada ao fato de que alguns conceitos matemáticos são conceitos do tipo científico, aprendidos em situação formal de ensino. A criança talvez não apresentasse, conforme relatado pela mãe, dificuldades na aplicação de tais conceitos em tarefas escolares, contudo, conforme mencionado por Vygotsky (1934/2001), conceitos científicos são empregados com dificuldade em situações espontâneas. Assim, durante as brincadeiras, F. parecia não reconhecer o significado dos números, não conseguindo transferir tal conceito para situações concretas. Ao longo dos atendimentos foi possível perceber uma grande evolução da criança no que se refere aos conceitos de quantidade. No final da pesquisa, F. já compreendia o conceito de "menos” em situações concretas e simples, as quais envolviam dois conjuntos de objetos. Contudo, ainda apresentava dificuldades para comparar as quantidades quando tal comparação envolvia três grupos. Por este motivo, a criança apresentou dúvidas, no pós-teste, ao responder à pergunta referente ao conceito "menos”. Ela comentou que estava em dúvida entre dois grupos (excluindo 
o grupo com mais objetos desta comparação); ao comparar entre os dois grupos restantes, a criança conseguiu dar a resposta correta.

Embora os testes tenham possibilitado a identificação da aprendizagem de alguns dos conceitos, a observação da criança durante os atendimentos mostrou-se mais eficaz para identificar evoluções mais sutis, como aquelas relacionadas a conceitos em processo de desenvolvimento, que não eram, ainda, totalmente dominados pela criança. Por exemplo, B. evoluiu no aprendizado dos conceitos de tamanho e V. avançou na aprendizagem de conceitos relacionados à quantidade e tamanho, contudo estes avanços não foram observados no pós-teste. FR., ao contrário, acertou o conceito de "menos” nos testes, mas não sabia aplicá-lo em todas as situações, apresentando uma melhora neste sentido, que também não pôde ser percebida por meio do teste.

Também observamos outras incongruências entre as informações obtidas pelos testes e os dados colhidos durante as observações. F. e FR. acertaram a questão referente ao conceito "lado direito”, tanto no pré-teste quanto no pós-teste; contudo, observou-se que ambas as crianças não dominavam tal conceito em situações práticas, o que sugere duas hipóteses: ambas as crianças são destras e se utilizaram da mão direita para apontar para a cartela do teste, fazendo com que, em caso de dúvida, apontassem para a opção que se encontrava no lado direito da cartela; ou as crianças aprenderam este conceito em uma situação formal de ensino, sabendo aplicá-lo em condições de teste, nos quais o conceito é representado num plano bidimensional. Contudo, estas crianças não conseguiam utilizá-lo nas situações concretas e espontâneas das brincadeiras, as quais exigiam o uso do conceito em relação ao seu próprio corpo, por não terem vivenciado experiências do tipo.

A disparidade observada em alguns momentos entre os dados dos testes e as observações durante as brincadeiras, chama a atenção para uma questão que envolve a utilização de testes de 
conceitos. Visto que os conceitos aqui trabalhados são conceitos espontâneos, desenvolvidos normalmente em situações diárias e lúdicas, estes têm uma característica peculiar: são mais facilmente utilizados em situações espontâneas, sendo, portanto, empregados com dificuldade em situações que exijam o seu uso consciente. Deste modo, os relatos do diário de campo, os quais ilustram situações espontâneas que ocorreram durante as brincadeiras, apontaram de maneira mais adequada a evolução da criança do que o Teste de Conceitos Básicos de Boehm, que exige um emprego consciente de cada conceito. De acordo com Vygotsky (1934/2001), quando pedimos para que a criança utilize conceitos espontâneos em situação de teste, estamos exigindo que utilize de maneira intencional o que ela só sabe utilizar de maneira espontânea e em situações cotidianas.

As crianças da creche não acertaram todo o teste, o que, de acordo com Boehm (1971), era esperado para a sua faixa etária; contudo, a aplicação do teste parece ter sido mais adequada para estas crianças que para as crianças da pesquisa, nas quais foram identificadas certas dificuldades: algumas das crianças com paralisia cerebral não permaneceram atentas às questões até o final do teste, sendo que estas crianças, especificamente, apresentam dificuldades para concentrar-se em qualquer tipo de atividade que demanda a manutenção da atenção por um longo período de tempo; certos conceitos, conforme mencionado anteriormente, foram apontados adequadamente no teste, mas a criança mostrou não dominá-los em situações práticas; por outro lado, algumas crianças demonstraram conhecer alguns conceitos em situações práticas, mas não acertaram as questões a eles referentes no teste, mostrando não conseguir generalizá-los para todas as situações. Podemos nos indagar, no entanto, se uma avaliação mais aprofundada das crianças da creche, na qual pudéssemos confrontar os resultados dos testes com o seu desempenho em atividades práticas, não revelaria disparidades, assim como encontramos para as crianças com deficiência. Talvez este tipo de teste de conceitos seja mais adequado para avaliar 
conceitos já dominados completamente pela criança, que já se tornaram conscientes, não sendo sensível o suficiente para avaliar conceitos espontâneos em fase de desenvolvimento.

Além disso, uma outra limitação do teste utilizado encontra-se no fato de que, neste, o conceito é apresentado em apenas uma situação. Contudo, um mesmo conceito pode fazer parte de mais de um domínio de conhecimento, sendo bem utilizado pela criança em situações relacionadas a um domínio, mas não a outro. A criança pode dominar, por exemplo, o conceito de “depois” numa situação referente ao domínio de espaço (“meu lugar na fila é depois do seu”), mas não dominá-lo numa situação referente a tempo ("vou escovar os dentes depois que almoçar”). Ou ainda, a criança pode dominar o conceito em algumas situações específicas, mas não em todas as situações possíveis, tal como no caso de F., que conseguia utilizar o conceito de “menos” quando a comparação envolvia apenas dois grupos de objetos.

Por outro lado, também se faz necessário citar algumas limitações da pesquisa que podem ter influenciado nos resultados. O pouco tempo disponível para a realização dos atendimentos, seja por limitações impostas pelas instituições, seja por limitações da própria pesquisadora, impossibilitou um trabalho mais aprofundado, de modo que observamos a necessidade de um maior número de atendimentos para a aprendizagem dos conceitos em tela. Por conta desta limitação, não foi possível trabalhar de forma semelhante todos os conceitos avaliados, sendo dada maior ênfase a apenas alguns deles; assim, tornou-se necessário relacionar os conceitos mais trabalhados por cada criança com os resultados por ela apresentados nos testes. A realização do pré-teste no contato inicial com a criança também pode ter gerado algumas dificuldades, visto que o conhecimento mútuo entre a criança e a pesquisadora poderia ter diminuído a ansiedade por parte da primeira e aumentado as possibilidades de ação por parte da segunda.

Uma outra dificuldade encontrada no decorrer deste estudo diz respeito aos múltiplos papéis da pesquisadora. Durante os atendimentos, ao mesmo tempo em que brincava e interagia 
com a criança, auxiliando-a nas funções que não conseguia executar com independência, a pesquisadora também deveria incluir os conceitos avaliados e observar o desempenho da criança. Além disso, ao relatar os acontecimentos no diário de campo, a pesquisadora precisava descrever e expor a sua própria conduta. Estas dificuldades também foram identificadas por outros autores, que salientam que o envolvimento pessoal do observador pode comprometer a avaliação posterior dos dados (CARVALHO, 1998; YIN, 2005). Visando reduzir a influência do seu envolvimento nas situações, a pesquisadora procurou relatar todos os acontecimentos na terceira pessoa, relembrando de todos os momentos como se estivesse observando de fora. Foram relatadas no diário de campo, todas as situações, mesmo aquelas nas quais a pesquisadora se deparou com alguma dificuldade. Relembrar dos atendimentos e refletir sobre tais momentos possibilitou que a pesquisadora repensasse sobre a própria prática terapêutica, possibilitando um crescimento profissional.

Não obstante Carvalho (1998) e Yin (2005) identifiquem limitações na técnica da observação participante, estes autores também salientam seus benefícios, quais sejam: a possibilidade de enxergar o problema de dentro, a postura ativa do pesquisador e o estabelecimento de uma relação menos artificial com o objeto da pesquisa.

Diante das limitações desta pesquisa, coloca-se a necessidade de que sejam realizadas outras investigações sobre o assunto, nas quais as crianças possam ser acompanhadas por um maior intervalo de tempo, possibilitando trabalhar mais os conceitos avaliados. Além disso, também sentimos a necessidade de desenvolver um teste de conceitos espontâneos que envolva um mesmo conceito em diferentes situações, no qual a criança os aplique espontaneamente, ou uma avaliação na qual o desempenho da criança seja observado em situações práticas e informais, visto que é nestes momentos que seus conceitos básicos são utilizados de forma natural. 
Com a realização desta pesquisa buscamos ressaltar a importância de fornecer oportunidades para que a criança com deficiência vivencie situações comuns a qualquer criança, visto que é nestas atividades cotidianas e lúdicas que se dá a formação dos conceitos espontâneos, essenciais para as aprendizagens futuras. Além disso, salientamos a importância da comunicação entre a criança e o adulto em tais atividades, sendo a linguagem fundamental para a apropriação do conhecimento e para o desenvolvimento cognitivo da criança. Neste sentido, observamos que não há a necessidade de se criar métodos terapêuticos distintos dos já existentes atualmente basta percebermos que os conceitos estão presentes em qualquer atividade, sendo papel do adulto identificá-los para as crianças.

Esperamos que este trabalho de pesquisa possa auxiliar a prática de todos os profissionais que lidam com crianças com deficiência e sirva de estímulo para os pais perceberem a grande importância que têm no desenvolvimento de seus filhos. 


\section{REFERÊNCIAS BIBLIOGRÁFICAS}

AGUIAR, J.S. Educação Inclusiva: Jogos para o ensino de conceitos. Campinas: Papirus, 2004.

ALMY, M. Spontaneous play: an avenue for intellectual development. Young Children, v. 22, n. 5, p. 265-277, 1967.

ALVES-MAZZOTTI, A.J.; GEWANDSNAJDER, F. O método nas ciências naturais e sociais: a pesquisa quantitativa e qualitativa. São Paulo: Pioneira, 1998.

AMORIM, C.A. Psicologia do brinquedo: perspectiva sócio-histórica. Revista Psicologia Argumento, ano 15, n. 21, p. 10-23, 1997.

BACH-Y-RITA, P. Brain plasticity as a basis of the development of rehabilitation procedures for hemiplegia. Scandinavian Journal of Rehabilitation Medicine, v.13, p. 73-81, 1981.

BLANCHE, E.I. Fazer junto com - não fazer para: a recreação e as crianças portadoras de paralisia cerebral. In: PARHAM, L.D.; FAZIO, L.S. A Recreação na Terapia Ocupacional Pediátrica. São Paulo: Santos, 2002. p. 202-218.

BOCK, M.A. Acquisition, maintenance and generalization of a categorization strategy by children with autism. Journal of Autism and Developmental Disorders, v. 24, n. 1, p. 39-51, 1994.

BOEHM, A.E. Teste de conceitos básicos de Boehm (BTBC). Rio de Janeiro: CEPA, 1977.

BOMTEMPO, E. Aprendizagem e brinquedo. In: WITTER, G.P.; LOMÔNACO, J.F.B. Psicologia da aprendizagem: áreas de aplicação. São Paulo: EPU, 1987. p. 1-14.

Brinquedos: critérios de classificação e análise. Cadernos do E.D.M. Comunicação e debates, v. 2, n. 2, p. 36-44, 1990.

BRAGA, L.W. Desenvolvimento cognitivo na paralisia cerebral: um estudo exploratório. 1986. Dissertação (Mestrado) - Faculdade de Educação, Universidade de Brasília, Brasília, 1986.

1995.

. Cognição e paralisia cerebral: Piaget e Vygotsky em questão. Salvador: SarahLetras,

BRUNER, J.S. Organization of early skilled action. Child Development, v. 44, p. 1-11, 1973. 
. Play: its role in development and evolution. New York: Penguin Books, 1976.

Juego, pensamiento y lenguaje. Perspectivas, v. 15, n. 1, p. 79-85, 1986.

. Le développement de l'enfant: savoir faire, savoir dire. 5. ed. Paris: PUF, 1996.

BRUNER, J.S.; GOODNOW, J.J; AUSTIN, G.A. A study of thinking. New York: Wiley, 1967. (Publicado originalmente em 1956).

BRYZE, K. Contribuições das narrativas ao Histórico Lúdico. In: PARHAM, L.D.; FAZIO, L.S. A Recreação na Terapia Ocupacional Pediátrica. São Paulo: Santos, 2002. p. 23-34.

CARABETTI, S.C.; LEME, M.I.S.; PRIETO, R.G. A construção do conceito de número em dois alunos com paralisia cerebral. Boletim de Psicologia, v. 55, n. 122, p. 23-41, 2005.

CARVALHO, L.M.G. As atividades lúdicas e a criança com paralisia cerebral: o jogo, o brinquedo e a brincadeira no cotidiano da criança e da família. 1998. Dissertação (Mestrado) Faculdade de Educação Física, Universidade Estadual de Campinas, Campinas, 1998.

CASTRO, E.D.; LIMA, E.M.F.A.; CASTIGLIOLI, M.C.; SILVA, S.N.P. Análise de atividades: apontamentos para uma reflexão atual. In: CARLO, M.M.R.P.; LUZO, M.C.M. Terapia Ocupacional: reabilitação física e contextos hospitalares. São Paulo: Roca, 2004. p. 47-73.

CERVO, A.L.; BERVIAN, P.A. Metodologia científica. 5. ed. São Paulo: Prentice Hall, 2002.

CHEN, R.; COHEN, L.G.; HALLETT, M. Nervous system reorganization following injury. Neuroscience, v. 111, n. 4, p. 761-773, 2002.

CIASCA, S.M.; MOURA-RIBEIRO, M.V.L.; TABAQUIM, M.L.M. Aprendizagem e paralisia cerebral. In: ROTTA, N.T.; OHLWEILER, L.; RIESGO, R.S. Transtornos da Aprendizagem: abordagem neurobiológica e multidisciplinar. Porto Alegre: Artmed, 2006. p. 409-415.

CRATTY, B.J. A inteligência pelo movimento: atividades físicas para reforçar a atividade intelectual. São Paulo - Rio de Janeiro: Difel, 1975.

CREPEAU, E.B. Análise de Atividades: uma forma de refletir sobre desempenho ocupacional. In: NEISTADT, M.E.; CREPEAU, E.B. Willard \& Spackman Terapia Ocupacional. 9. ed. Rio de Janeiro: Guanabara Koogan, 2002. p. 121-133.

CUNHA, N.H.S. Brinquedo, linguagem e alfabetização. Petrópolis: Vozes, 2004. 
DANTAS, H. Brincar e Trabalhar. In: KISHIMOTO, T.M. O brincar e suas teorias. São Paulo: Pioneira Thomson Learning, 2002. p. $111-121$.

DINIZ, D.; MEDEIROS, M.; SQUINCA, F. Reflexões sobre a versão em Português da Classificação Internacional da Funcionalidade, Incapacidade e Saúde. Cadernos de Saúde Pública, v. 23, n. 10, 2007.

DORETTO, D. Fisiopatologia clínica do sistema nervoso: fundamentos de semiologia. 2. ed. São Paulo: Atheneu, 2001.

EAGLE, R.S. Deprivation of early sensoriomotor experience and cognition in the severely involved cerebral-palsied child. Journal of Autism and Developmental Disorders, v. 15, n. 3, p. 269-283, 1985.

ERHARDT, R.P.; MERRILL, S.C. Disfunção neurológica em crianças. In: NEISTADT, M.E.; CREPEAU, E.B. Willard \& Spackman Terapia Ocupacional. 9. ed. Rio de Janeiro: Guanabara Koogan, 2002. p. 542-565.

FARIAS, N.; BUCHALLA, C.M. A Classificação Internacional de Funcionalidade, Incapacidade e Saúde da Organização Mundial da Saúde: conceitos, usos e perspectivas. Revista Brasileira de Epidemiologia, v. 8, n. 2, 2005.

FERLAND, F. O modelo lúdico: a utilização do potencial terapêutico do brincar. Temas sobre Desenvolvimento, v.14, n.82, p. 50-55, 2005.

. O modelo lúdico: o brincar, a criança com deficiência física e a terapia ocupacional. São Paulo: Roca, 2006.

FERRARETTO, I.; SOUZA, A.M.C. Paralisia Cerebral: aspectos práticos. São Paulo: Editora Memnon, 1998.

FERRIGNO, I.S.V. - O que é Terapia Ocupacional? In: KUDO, A.M. et al. Fisioterapia, fonoaudiologia e terapia ocupacional em pediatria. 2.ed. São Paulo: Savier, 1994. p. 187-9.

FINNIE, N. O manuseio em casa da criança com paralisia cerebral. 2. ed. São Paulo: Editora Manole, 1980.

GARCÍA, M.T.; BEATÓN, G.A. Necessidades educativas especiais: desde o enfoque históricocultural. São Paulo: Linear B, 2004.

GIANNI, M.A. Paralisia Cerebral. In: TEIXEIRA, E. et al. Terapia Ocupacional na Reabilitação Física. São Paulo: Roca, 2003. p. 89-100. 
GIL, A.C. Métodos e Técnicas de Pesquisa Social. 4. ed. São Paulo: Atlas, 1994. (Publicado originalmente em 1987).

GÓES, M.C.R. Relações entre desenvolvimento humano, deficiência e educação: contribuições da abordagem histórico-cultural. In: Oliveira, M.K.; Rego, T.C.; Souza, D.T.R. (Org.). Psicologia, educação e as temáticas da vida contemporânea. São Paulo: Moderna, 2002. p. 95114.

HARTLEY, R.E. Play, the essential ingredient. Childhood Education, v. 48, n. 2, p. 80-84, 1971.

JOHANSSON, B.B. Brain plasticity in health and disease. Keio Journal of Medicine, v. 53, n. 4, p. 231-46, 2004.

JURDI, A.P.S. Atividade lúdica: uma atividade criativa. Temas sobre desenvolvimento, v. 10, n. 56, p. 46-50, 2001.

O processo de inclusão escolar do aluno com deficiência mental: a atuação do terapeuta ocupacional. 2004. Dissertação (Mestrado) - Instituto de Psicologia, Universidade de São Paulo, São Paulo, 2004.

KEIL, F.C. Concepts, kinds and cognitive development. Cambridge: MIT Press, 1989.

KEIL, F.C.; SMITH, W.C.; SIMONS, D.J.; LEVIN, D.T. Two dogmas of conceptual empiricism: implications for hybrid models of the structure of knowledge. Cognition, v. 65, p. 103-135, 1998.

KISHIMOTO, T.M. O jogo e a educação infantil. In: (org.) Jogo, brinquedo, brincadeira e a educação. São Paulo: Editora Cortez, 1996. p. 13-27.

Bruner e a Brincadeira. In: Thompson Learning, 2002. p. 139-153. (org.) O brincar e suas teorias. São Paulo: Pioneira

KOHLMEYER, K. Avaliação dos componentes de desempenho sensorial e neuromuscular. In: NEISTADT, M.E.; CREPEAU, E.B. Willard \& Spackman Terapia Ocupacional. 9. ed. Rio de Janeiro: Guanabara Koogan, 2002. p. 202-237.

LA TAILLE, Y. Desenvolvimento do juízo moral e afetividade na teoria de Jean Piaget. In: LA TAILLE, Y; OLIVEIRA, M.K.; DANTAS, H. Piaget, Vygotsky, Wallon: teorias psicogenéticas em discussão. São Paulo: Summus, 1992. p. 47-73.

LAMÔNICA, D.A.C.; VITO, L.P.M.; ROUSTON, J.C.; WITHAKER, M.E.; RIBEIRO, L.M. Avaliação do aspecto semântico da linguagem em paralíticos cerebrais. Salusvita, v. 22, n. 2, p. 229-237, 2003. 
LE BOULCH, J. A educação pelo movimento: a psicocinética na idade escolar. Porto Alegre: Artes Médicas, 1983.

LEVITT, S. O tratamento da paralisia cerebral e do retardo motor. São Paulo: Manole, 2001.

LIANZA, S. Medicina de Reabilitação. 3. ed. Rio de Janeiro: Guanabara Koogan S.A., 2001.

LIMONGI, S.C.O. Considerações sobre situações de brinquedo e a linguagem em crianças portadoras de paralisia cerebral. Distúrbios da comunicação, v. 5, n. 1, p. 41-58, 1992.

Avaliação da relação linguagem-cognição na paralisia cerebral. Arquivos de NeuroPsiquiatria, v. 59, n. 3A, Supl. 1, p. 196, 2001.

LLORENS, L.A. The effects of stress on growth and development. American Journal of Occupational Therapy, v. 28, n. 2, p. 82-86, 1974.

LOMÔNACO, J.F.B. A natureza dos conceitos: visões psicológicas. 1997. Tese (Livre Docência) - Instituto de Psicologia, Universidade de São Paulo, São Paulo, 1997.

LOMÔNACO, J.F.B.; CAON, C.M.; HEURI, A.L.P.V.; SANTOS, D.M.M.; FRANCO, G.T. Do característico ao definidor: um estudo exploratório sobre o desenvolvimento de conceitos. Psicologia: Teoria e Pesquisa, v. 12, n. 1, p. 51-60, 1996.

LOMÔNACO, J.F.B.; CAPOVILLA, A.G.S.; COSTA, C.E.; ALBERNAZ, J.M.; SOUZA, M.A.; AGUIAR, R.M. Desenvolvimento de conceitos: o paradigma das descobertas. Psicologia Escolar e Educacional, v. 4, n. 2, p. 31-39, 2000.

LOMÔNACO, J.F.B.; PAULA, F.V.; MELLO, C.B.; ALMEIDA, F.A. Desenvolvimento de conceitos: o paradigma das transformações. Psicologia: Teoria e Pesquisa, v. 17, n. 2, p. 161168, 2001.

LORENZINI, M.V. Brincando no ambiente natural: uma contribuição para o desenvolvimento sensório-motor da criança portadora de paralisia cerebral. 1999. Tese (Doutorado) - Faculdade de Educação Física, Universidade Estadual de Campinas, Campinas, 1999.

LÜDKE, M.; ANDRÉ, M.E.D.A. Pesquisa em educação: abordagens qualitativas. São Paulo: EPU, 1986.

LUNDY-EKMAN, L. Neurociência: fundamentos para reabilitação. Rio de Janeiro: Elsevier, 2004.

MAEGAKI, Y.; MAEOKA, Y.; ISHII, S.; EDA, I.; OHTAGAKI, A.; KITAHARA, T.; SUZUKI, N.; YOSHINO, K.; IESHIMA, A.; KOEDA, T.; TAKESHITA, K. Central motor 
reorganization in cerebral palsy patients with bilateral cerebral lesions. Pediatric Research, v. 45, n. 4 Pt 1, p. 559-67, 1999

MARCONI, M.A.; LAKATOS, I. Fundamentos de Metodologia Científica. 5. ed. São Paulo: Atlas, 2003.

MARINHO, P. A pesquisa em ciências humanas. Petrópolis: Vozes, 1980.

MEDIN, D.L. Concepts and conceptual structure. American Psycologist, v. 44, n. 12, p. 14691481, 1989.

MELO, A.; GABRIELI, A.P.; RODRIGUES, B.; LIMA, C.; NORA, D.B.; CARDOSO, E. et al. Consenso sobre o uso da toxina botulínica na paralisia cerebral. Arquivos Brasileiros de Paralisia Cerebral. v.1, n.2, p. 18-25, 2005.

MEYERHOF, P.G.; PRADO, T.F.A. Intervenção precoce em paralisia cerebral. In: FERRARETTO, I.; SOUZA, A.M.C. Paralisia Cerebral: aspectos práticos. São Paulo: Editora Memnon, 1998. p. 251-269.

MISSIUNA, C.; POLLOCK, N. Play deprivation in children with disabilities: the role of the Occupational Therapist in preventing secondary disability. American Journal of Occupational Therapy, v. 45, n. 10, p. 882-888, 1991.

MORAES, M.L.S.; CARVALHO, A.M.A. Brincar: uma revisão de algumas concepções clássicas. Boletim de Psicologia, v. 37, n. 86, p. 1-23, 1987.

MOTTA, M.P.; TAKATORI, M. A assistência em terapia ocupacional sob a perspectiva do desenvolvimento da criança. In: PRADO DE CARLO, M.M.R.; BARTALOTTI, C.C. Terapia Ocupacional no Brasil: fundamentos e perspectivas. São Paulo: Plexus, 2001. p. 117-135.

MURPHY, G.L.; MEDIN, D.L. The role of theories in conceptual coherence. Psychological Review, v. 92, n. 3, p. 289-316, 1985.

NOGUEIRA, O. Pesquisa Social: introdução às suas técnicas. 3. ed. São Paulo: Nacional, 1975.

NUDO, R.J.; FRIEL, K.M. - Cortical plasticity after stroke: implications for rehabilitation. Revue Neurologique (Paris), v. 155, n. 9, p. 713-7, 1999.

NUÑEZ, I.B.; PACHECO, O.G. Formação de conceitos segundo a teoria de assimilação de Galperin. Cadernos de Pesquisa, v. 105, p. 92-109, 1998.

OLIVEIRA, C.E.N.; SALINA, M.E.; ANNUNCIATO, N.F. Fatores ambientais que influenciam a plasticidade do SNC. Acta Fisiátrica, v. 8, n. 1, p. 6-13, 2001. 
OLIVEIRA, M.B. Rumo a uma teoria dialética de conceitos. In: Abrantes, P. Epistemologia e cognição. Brasília: Editora da Universidade de Brasília, 1994. p. 25-68.

OLIVEIRA, M.K. Vygotsky: alguns equívocos na interpretação de seu pensamento. Cadernos de Pesquisa, n. 81, p. 67-74, 1992.

PÁDUA, E.M.M. Metodologia da Pesquisa: Abordagem teórico-prática. 10. ed. Campinas: Papirus, 2004.

PALANGANA, I.C. Desenvolvimento e aprendizagem em Piaget e Vygotsky: a relevância do social. 3. ed. São Paulo: Summus, 2001.

PATO, T.R.; PATO, T.R.; SOUZA, D.R.; LEITE, H.P. Epidemiologia da paralisia cerebral. Acta Fisiátrica, v. 9, n.2, p. 71-76, 2002.

PENAZZO, A.A. Um estudo sobre a aprendizagem de conceitos por crianças deficientes mentais moderados. 1994. Tese (Doutorado) - Instituto de Psicologia, Universidade de São Paulo, São Paulo, 1994.

PENTEADO, R.Z.; SEABRA, M.N.; BICUDO-PEREIRA, I.M.T. - Ações educativas em saúde da criança: o brincar enquanto recurso para participação da família. Revista Brasileira de Crescimento e Desenvolvimento Humano, v. 6, n. 1/2, p. 49-56, 1996.

PERES, R.C.N.C. O lúdico no desenvolvimento da criança com paralisia cerebral espástica. Revista Brasileira de Crescimento e Desenvolvimento Humano, v. 14, n. 3, p. 37-49, 2004.

PFEIFER, L.I. Comprometimento motor e aquisição de habilidades cognitivas em crianças portadoras de paralisia cerebral. Temas sobre desenvolvimento, v. 6, n. 31, p. 4-13, 1997.

PIAGET, J. A formação do símbolo na criança. Rio de Janeiro: Zahar, 1975. (Publicado originalmente em 1945).

Mastery Play. In: BRUNER, J.S. Play: its role in development and evolution. New York: Penguin Books, 1976. p. 166-171.

PIERRI, S.A.; KUDO, A.M. Brinquedos e brincadeiras no desenvolvimento infantil. In: KUDO, A.M.; MARCONDES, E. Fisioterapia, fonoaudiologia e terapia ocupacional em pediatria. 2. ed. São Paulo, Savier, 1994. p. 246-252.

PIZZIGATTI, C.P. Arte na formação do Terapeuta Ocupacional. 1990. Dissertação (Mestrado), Universidade Metodista de Piracicaba, Piracicaba, 1990. 
PRADO, M.M.R. Des-cobrindo o lúdico. Revista de Terapia Ocupacional da USP, v. 2, n. 4, p. 157-163, 1991.

QUEIROZ E MELO, M.F.A. A perspectiva sociocultural e as interações lúdicas nos primeiros anos da infância: revendo contribuições. Revista Brasileira do Crescimento e Desenvolvimento Humano, v. 14, n. 2, p. 46-53, 2004.

RAMM, P.A Pediatric Occupational Therapy. In: WILLARD, H.S. et al. Willard and Spackman's occupational therapy. Philadelphia (EUA): J.B. Lippincott Co., 1988. p. 601-627.

REY, G.F. Pesquisa qualitativa e subjetividade: os processos de construção da informação. São Paulo: Pioneira Thomson Learning, 2005.

ROCHA, E.F. Experiências em Reabilitação: discutindo a organização de serviços e os modelos assistenciais. In: . Reabilitação de pessoas com deficiência. São Paulo: Roca: 2006. p. 61134.

ROSENBAUM, P. Physical activity play in children with disabilities: a neglected opportunity for research? Child Development, v. 69, n. 3, p. 607-608, 1998.

ROTHMAN, J.G. Understanding order of movement in youngsters with cerebral palsy. Perceptual and Motor Skills, v. 65, p. 391-397, 1987.

SCHAAF, R.C. - Play behavior and Occupational Therapy. American Journal of Occupational Therapy, v. 44, n. 1, p. 68-75, 1990.

SCHEUER, C.I. Produção de relações espaciais em deficientes mentais leves: uso de figuras. Temas sobre desenvolvimento, v. 2, n. 11, p. 15-22, 1993.

SHAPIRO, B.K. - Cerebral palsy: A reconceptualization of the spectrum. The Journal of Pediatrics, v. 145 (2 Suppl), p. S3-7, 2004.

SILVA, R.K. A neuroplasticidade no desenvolvimento de crianças com paralisia cerebral. Temas sobre desenvolvimento, v. 34, n.6, p. 7-13, 1997.

SOBRINHO, J.B.R. - Neuroplasticidade e a recuperação da função após lesões cerebrais. Acta Fisiátrica, v, 2, n. 3, p. 27-30, 1995.

SPARLING, J.W.; WALKER, D.F.; SINGDAHLSEN, J. Play techniques with neurologically impaired preschoolers. American Journal of Occupational Therapy, v. 38, n. 9, p. 603-612, 1984.

SPECTOR, C.C. The Boehm Test of Basic Concepts: exploring the results for cognitive deficits. Journal of Learning Disabilities, v. 12, n. 8, p. 564-567, 1979. 
SYLVA, K.; BRUNER, J.S.; GENOVA, P. The role of play in the problem-solving of children 35 years old. In: BRUNER, J.S. Play: its role in development and evolution. New York: Penguin Books, 1976. p. 244-257.

TAKATORI, M. O brincar no cotidiano da criança com deficiência física: privilegiando um olhar para a construção das intervenções em reabilitação. 1999. Dissertação (Mestrado) Instituto de Psicologia, Universidade de São Paulo, São Paulo, 1999.

TEIXEIRA, E.; SAURON, F.N.; SANTOS, L.S.B.; OLIVEIRA, M.C. Terapia Ocupacional na Reabilitação Física. São Paulo: Roca, 2003.

THE BOBATH CENTRE. Apostila para o curso Conceito Bobath - Tratamento Neuroevolutivo. Londres, 1997.

TINARI, F.; RODRIGUES, I.; SOARES, N.; QUEIROZ, T. Manual Pedagógico do Professor: $1^{\circ}$ e $2^{\circ}$ ciclos. São Paulo: Editora Didática Paulista, 1999.

TOLENTINO, M.; SILVA, R.R.; ROCHA-FILHO, R.C.; TUNES, E. Ensino de conceitos de química - Matéria: exemplo de um sistema de conceitos científicos. Ciência e Cultura, v. 38, n. 10, p. 1721- 1724, 1986.

TRIVIÑOS, A.N.S. Introdução à pesquisa em ciências sociais: a pesquisa qualitativa em educação. São Paulo: Atlas, 1987.

VARGHA-KHADEM, F.; ISAACS, E.; WERF, S.V.D.; ROBB, S.; WILSON, J. Development of intelligence and memory in children with hemiplegic cerebral palsy: the deleterious consequences of early seizures. Brain, v. 115, p. 315-329, 1992.

VILLAR, F.A.S. - Alterações centrais e periféricas após lesão do Sistema Nervoso Central. Considerações e Implicações para a prática da fisioterapia. Revista Brasileira de Fisioterapia, v. 2, n. 1, p. 19-34, 1997.

VYGOTSKY, L.S. Play and its role in the mental development of the child. In: In: BRUNER, J.S. Play: its role in development and evolution. New York: Penguin Books, 1976. p. 537-554.

. Obras Escogidas V - Fundamentos de defectología. Madrid: Visor, 1997. (Publicado originalmente em 1983).

. A formação social da mente: o desenvolvimento dos processos psicológicos superiores. 6. ed. São Paulo: Martins Fontes, 1998.

A construção do pensamento e da linguagem. São Paulo: Martins Fontes, 2001 (Publicado originalmente em 1934). 
YIN, R.K. Estudo de caso: planejamento e métodos. 3. ed. Porto Alegre: Bookman, 2005.

ZERBINATO, L.; MAKITA, L.M.; ZERLOTI, P. Paralisia Cerebral. In: TEIXEIRA, E. et al. Terapia Ocupacional na Reabilitação Física. São Paulo: Roca, 2003. p. 503-534. 


\section{APÊNDICE A}

TERMO DE CONSENTIMENTO LIVRE E ESCLARECIDO

Meu nome é Ana Paula Martins Cazeiro, sou terapeuta ocupacional, trabalho na e sou aluna do Curso de Pós-graduação em Psicologia Escolar e do Desenvolvimento Humano (nível - mestrado) do Instituto de Psicologia da Universidade de São Paulo. Estou realizando uma pesquisa com o objetivo de avaliar se as brincadeiras ajudam a criança com paralisia cerebral a aprender alguns conceitos básicos, que são importantes para que ela possa aprender outras coisas no decorrer de sua vida.

Para que a criança possa participar da pesquisa, será necessário que ela acerte pelo menos quatro dos seis primeiros desenhos da avaliação, que dizem respeito a objetos do dia a dia. Entretanto, mesmo que a criança não acerte estas perguntas e os resultados não sejam utilizados na pesquisa, ela poderá participar dos atendimentos, caso seja de interesse dela ou de seus responsáveis. A criança também não precisará acertar as outras perguntas da avaliação, pois o que queremos saber é exatamente se as brincadeiras poderão ajudá-la a aprender conceitos de espaço, quantidade e de tempo. Um cuidador da criança (mãe, pai ou outro adulto responsável por ela) participará de uma entrevista inicial, na qual serão solicitadas algumas informações a respeito das brincadeiras que a criança costuma realizar.

A criança, então, participará de 16 atendimentos de uma hora cada, num período de quatro a cinco meses, nos quais trabalharemos os conceitos que ela tiver dificuldades através das brincadeiras que ela gostar de realizar. Depois dos 16 atendimentos, faremos novamente a avaliação por meio dos mesmos desenhos utilizados anteriormente.

Esperamos, com esta pesquisa, ajudar na compreensão de como ocorre o desenvolvimento da criança com paralisia cerebral e na melhoria dos métodos de tratamento usados atualmente. Os dados das crianças participantes não serão divulgados, sendo apresentados apenas os resultados gerais da pesquisa. Os atendimentos ocorrerão na instituição que a criança costuma freqüentar, mas não têm nenhuma relação com os atendimentos que a criança já recebe ou receberá nesta instituição. Sua participação é gratuita e voluntária. É também possível que a criança deixe de fazer parte da pesquisa a qualquer momento, sem prejuízo algum, se ela ou seus responsáveis assim desejarem. 
Meus contatos são:

Caso possa participar da pesquisa, é importante que preencha os espaços abaixo para que a participação da criança só ocorra com a sua autorização.

$\mathrm{Eu}$ o(a) menor documento autorizo atividade lúdica para a formação de conceitos básicos por crianças com seqüelas de paralisia cerebral, realizada pela pesquisadora Ana Paula Martins Cazeiro, em atendimentos de uma hora cada, uma vez por semana, totalizando 16 atendimentos.

Data

Assinatura

Desde já agradeço,

Ana Paula Martins Cazeiro. 


\section{APÊNDICE B}

\section{QUESTIONÁRIO SOBRE BRINCADEIRAS ${ }^{52}$}

1 - Informações gerais

Nome da criança:

Data de Nascimento:

Sexo:

Data:

Informante(s):

Grau de parentesco:

Problema apresentado pela criança:

Freqüenta escola? De que tipo? Está em que série?

Em sala de aula comum ou especial?

Realiza (ou realizou) algum tratamento terapêutico? De que tipo?

Grau de escolaridade dos pais?

2 - Exame lúdico atual

A. Com o que a criança brinca?

- Brinquedos:

- Materiais (outros materiais, além dos brinquedos. Ex: panelas, caixas, lápis, papel, cola, etc.):

- Bichos de estimação:

B. Como a criança brinca com os brinquedos e os outros materiais? (Marque apenas o que a criança faz).

- Ela não pára quieta com um mesmo brinquedo, toda hora mudando de brinquedo? ( )

- Ela fica bastante tempo com o mesmo brinquedo? ( )

- Ela brinca sempre da mesma forma, nunca mudando o jeito de usar os objetos? ( )

- Inventa outras formas de brincar com os objetos? ( )

- Ela usa a imaginação, inventando histórias, personagens, etc.? ( )

- Só brinca com um tipo de brinquedo, não se interessando por outros tipos? ( ). Qual:

- Só brinca se alguém estiver junto? ( )

- Ela brinca da maneira esperada com cada tipo de brinquedo? Por exemplo, quando o brinquedo é panelinha, ela brinca de fazer comidinha, quando é carrinho, brinca de corrida, etc. ( )

- Obs:

${ }^{52}$ Questionário para os cuidadores baseado no Histórico Lúdico (Takata, 1974 apud Bryze, 2002) 
C. Qual tipo de brincadeira ela prefere e qual tipo ela evita?

D. Com quem a criança brinca?

Sozinha ( ) pais ( ) irmãos ( ) irmãs ( ) outras crianças ( )

Outros:

E. Como a criança brinca com as pessoas?

- Ela gosta de brincar com poucas pessoas ( ). Brinca com muitas pessoas ( ). Prefere brincar com crianças mais novas ( ), da mesma idade dela ( ), crianças mais velhas ( ) ou com adultos ( ).

Ela gosta de mandar na brincadeira ( ). Ela obedece às regras das brincadeiras ( ).

F. Quais as posturas corporais que a criança usa enquanto brinca?

Deitada ( ) Sentada no chão ( ) Sentada em cadeirinha ( ) No colo ( ) De pé ( )

Outras:

G. Onde a criança brinca?

Em casa: dentro de casa

ao ar livre

Na comunidade: parque escola igreja outras áreas

H. Quando a criança brinca? (Indique em que momentos do dia a criança tem oportunidades para brincar, durante a semana e nos finais de semana? Diga com quem ela brinca em cada momento: se ela brinca sozinha em algum destes momentos, escreva que brinca sozinha).

\section{Durante a semana:}

De manhã ( ) Por quanto tempo: Brinca com quem:

De tarde ( ) Por quanto tempo: Brinca com quem:

De noite ( ) Por quanto tempo: Brinca com quem:

Nos finais de semana:

De manhã ( ) Por quanto tempo: Brinca com quem:

De tarde ( ) Por quanto tempo: Brinca com quem:

De noite ( ) Por quanto tempo: Brinca com quem:

Obs: 


\section{APÊNDICE C}

\section{QUESTIONÁRIO SOBRE O DESENVOLVIMENTO E A PARTICIPAÇÃO DA CRIANÇA}

Nome da criança:

Responsável:

1) Como foi a gestação da criança (foi uma gestação planejada, houve algum problema)?

2) Como foi o nascimento?

3) Como foi descoberta da paralisia cerebral? Como foi a aceitação?

4) Como foi o desenvolvimento da criança?

5) Quais tratamentos a criança realiza no momento (e onde)?

6) Quais tratamentos a criança já realizou (e onde)?

7) Como é a sua participação nas atividades familiares (ela participa da rotina da família, dos eventos familiares, como é a relação com os parentes)?

8) Como é sua participação na comunidade (acompanha a família na igreja, no mercado, brinca com as crianças, passeia, etc.)?

9) Como é a sua família (onde mora, como é a casa, quem mora com a criança, quantos irmão tem)?

10) A família trata a criança assim como as demais crianças (e filhos) ou há um tratamento diferenciado?

11) Como é o dia a dia da criança? 


\section{APÊNDICE D}

\section{BRINCADEIRAS SELECIONADAS PARA A PESQUISA}

No decorrer da pesquisa, algumas brincadeiras foram selecionadas pela pesquisadora e oferecidas às crianças, outras brincadeiras foram por elas solicitadas ou foram desenvolvidas na dinâmica dos próprios atendimentos. Os pais de algumas crianças e outros profissionais também contribuíram para a elaboração das mesmas. Algumas idéias também foram desenvolvidas a partir de brincadeiras citadas por alguns autores (CRATTY, 1975; CUNHA, 2004; LE BOULCH, 1983; TINARI et al., 1999). As brincadeiras realizadas nesta pesquisa ${ }^{53}$ foram analisadas com base nos critérios descritos no capítulo 5 (Método) e serão apresentadas a seguir.

\section{Vira Lata:}

Descrição sumária:

Os participantes devem acertar as bolas nas latas.

Tipo de brinquedo:

- Material: latas de alumínio ou de plástico e bolas.

- Nível de estruturação ${ }^{54}$ : estruturado.

- Tipo de regras: explícitas e simples.

- Nível de complexidade ${ }^{55}$ : pouco complexo.

- Nível de cooperação: competitivo.

Nome comercial: Vira Lata.

- Marca: Elka.

- Componentes: seis latas numeradas, confeccionadas de papelão e com fundos de plástico; duas bolas de plástico.

\footnotetext{
${ }^{53}$ Serão apresentadas apenas as brincadeiras que foram de fato realizadas pelas crianças da pesquisa, sendo excluídas deste relato as brincadeiras selecionadas pela pesquisadora que não chegaram a ser oferecidas às crianças participantes, ou, embora oferecidas, não foram escolhidas em nenhum momento.

${ }^{54}$ Segundo Bomtempo (1990), o brinquedo estruturado é aquele que reflete a finalidade a que se destina (por exemplo, panelinha é para brincar de casinha, carro é para brincar de corrida, etc.), o brinquedo semi-estruturado permite que, além de brincar da maneira sugerida pelo objeto, a criança descubra outras formas de brincar com ele, e o brinquedo não-estruturado permite a livre expressão da criança.

${ }^{55}$ Brinquedo complexo é aquele que possui diferentes etapas ou apresenta regras complexas.
} 


\section{Usos do objeto:}

- Procedimentos: as latas são colocadas enfileiradas, formando um triângulo ou empilhadas. Os participantes jogam as bolas na tentativa de acertar o maior número possível de latas. Ganha a criança que acertar mais latas de uma só vez ou no final da rodada.

- Variações: ao invés de latas, podemos utilizar rolos de papel ou cones de costura. Podemos utilizar bolas de diferentes tamanhos e pesos, para que a criança escolha qual prefere ou para que se estabeleça que, a cada rodada, deverá ser utilizada uma determinada bola. Também é possível colocar umas latas de um lado e outras latas (ou objetos diferentes, por exemplo, pinos de boliche ou cones de costura) do outro lado, para que a criança diferencie se está jogando de um lado ou do outro. Podemos estabelecer ${ }^{56}$ que, em cada rodada, a bola só poderá ser arremessada por uma determinada mão, ou que as latas que estão de um lado, só poderão ser derrubadas pela mão ou pé que está do mesmo lado. Podemos utilizar latas ou cones de tamanhos diferentes; também é possível que a criança só possa derrubar, por exemplo, as latas pequenas com as bolas pequenas, as médias, com as bolas médias e as grandes, com as bolas grandes. Podemos colar números nas latas e colocá-las enfileiradas de acordo com o número que apresentam. Os números das latas derrubadas poderão ser somados, vencendo a criança que conseguir o maior valor. Podemos utilizar latas de diferentes cores e estabelecer que a criança deva acertar apenas as latas de uma mesma cor. Outra opção é sortear, após a partida, uma cor, para que vença a criança que tiver acertado mais ou menos latas daquela cor. Também podemos colocar as latas em diferentes locais do ambiente, por exemplo, em cima e embaixo da mesa, longe ou perto da criança, dentro e fora do armário.

- Adaptações: para a criança que não tem controle para segurar, podemos colocar a bola sobre uma mesinha, então, a criança a empurra até que caia no chão para acertar as latas. Outra opção para a criança que não consegue lançar a bola, é colocarmos uma superfície inclinada a sua frente (uma cunha ou uma canaleta, por exemplo), para que ela solte a bola e esta role até as latas. Para crianças com visão subnormal, podemos colar fitas adesivas de cores contrastantes nas latas e colocar um guizo dentro da bola e grãos dentro das latas. Para que a criança consiga recuperar a bola com maior facilidade, podemos colocá-la dentro de uma meia fina ou saco, e amarrá-la a um

\footnotetext{
${ }^{56} \mathrm{O}$ adulto pode fazer sugestões e fornecer os materiais adequados, contudo, todas as modificações nas brincadeiras devem ser acordadas com a(s) criança(s) participante(s).
} 
barbante. Se a criança apresenta mais facilidade em usar os pés, podemos colocar a criança posicionada em uma cadeira para que ela chute a bola em direção aos pinos.

Desenvolvimento e aprendizagem:

- o que favorece: coordenação olho-mão, lateralidade, cores, noções de aritmética, quantidade e espaço.

- conceitos que podem ser trabalhados: mais, menos, muitos, poucos, longe, perto, em cima, embaixo, lado, lado direito, lado esquerdo, quase (quase acertou a lata), pequeno, médio, grande, alto, baixo (ao fazerem torres com as latas empilhadas), dentro, fora, atrás, à frente (acertar as bolas que estão atrás, por exemplo), forte, fraco (quanto à força necessária para lançar a bola e acertar as latas), etc.

\section{Bola ao cesto:}

\section{Descrição sumária:}

Os participantes devem acertar as bolas dentro de cestos.

Tipo de brinquedo:

- Material: bolas e cestos.

- Nível de estruturação: semi-estruturado.

- Tipo de regras: explícitas e simples.

- Nível de complexidade: pouco complexo.

- Nível de cooperação: competitivo ou cooperativo.

Usos do objeto:

- Procedimentos: colocamos os cestos na frente da criança, que deverá lançar a bola e acertar dentro dos mesmos. É possível brincar individualmente ou em grupos (neste caso, o objetivo será que as crianças consigam acertar dentro dos cestos todas as bolas que possuem).

- Variações: ao invés de utilizar cestos, podemos utilizar caixas de papelão, latas ou bacias de diferentes tamanhos, para que a criança escolha em qual acertará. Podemos colocar as caixas em diferentes locais, para que a criança escolha se acertará a bola na caixa que está de um lado, do outro, em cima ou embaixo dos móveis. Podemos utilizar bolas de diferentes cores, tamanhos, texturas e pesos. Podemos colocar cartões com cores em cada caixa (ou pintar a caixa) e estabelecer que cada bola deva ser acertada no cesto de mesma cor. Podemos colocar números nas caixas e estabelecer que devam acertar, em cada caixa, bolas correspondentes ao número 
indicado. Podemos dar a metade das bolas para cada criança ou estabelecer que a criança deverá acertar a metade das bolas em cada caixa. Podemos colocar uma cunha ao lado de outra, com as partes maiores encostadas, formando duas rampas opostas; então, a criança solta a bola no alto da rampa para ver ser a bola cairá na caixa que está no lado direito ou esquerdo. Podemos colocar uma cunha sobre o tablado com a parte mais fina voltada para a beirada; depois colocamos uma caixa no chão, para que a criança solte a bola sobre a cunha e a acerte na caixa. Podemos dificultar: tentarmos acertar a bola pequena no cesto pequeno, a média, no cesto médio e a grande, no cesto grande. Crianças menores poderão gostar de brincar também com as embalagens (caixas, latas, nas quais as bolas são guardadas), brincando de retirar, colocar, fechar e abrir.

- Adaptações: a criança que não consegue lançar a bola poderá empurrá-la de cima de uma mesa, para que caia numa caixa colocada no chão, ou poderá colocá-la sobre uma superfície inclinada, para que a bola role e caia na caixa (que deverá estar deitada de lado, no chão). Também podemos usar rolos de papelão ou cones de diferentes tamanhos, para que a criança coloque a bola dentro (pelo orifício) e esta deslize até o cesto.

Desenvolvimento e aprendizagem:

- o que favorece: coordenação olho-mão, cores, noções de espaço e quantidade.

- conceitos que podem ser trabalhados: longe, perto, dentro, fora, grande, pequeno, médio, macio, duro (consistência das bolas), mais, menos, muitos, poucos, lado, lado direito, lado esquerdo, em cima, embaixo, sobre, frente, atrás (acertar o cesto que está atrás), metade, quase (quase acertou), embaixo (quando a bola cai embaixo de algum móvel ou quando a criança brinca de derrubar a bola de uma superfície alta e acertar a caixa que está embaixo, no chão), antes, depois (quanto à seqüência em que as bolas devem ser lançadas ou os cestos devem ser acertados), cheio, vazio (se o cesto está cheio ou vazio), etc.

\section{Corrida de carrinhos:}

Descrição:

Os participantes puxam carrinhos de corrida por meio de barbantes.

Tipo de brinquedo:

- Material: dois ou mais carrinhos no formato de carrinhos de corrida, fios de barbante de tamanho variável de acordo com o percurso, faixa de largada e de chegada (pode ser confeccionada com E.V.A. ou cartolina). 
- Nível de estruturação: estruturado.

- Tipo de regras: explícitas e simples.

- Nível de complexidade: pouco complexo.

- Nível de cooperação: competitivo.

Usos do objeto:

- Procedimentos: amarramos um pedaço de barbante em cada carrinho. Colamos as faixas de largada e de chegada. Posicionamos os carrinhos no início do percurso e as crianças se sentam no fim do mesmo, atrás da faixa de chegada. Ao ser dada a largada, as crianças começam a puxar o barbante, enquanto os carrinhos se aproximam. Ganha o carrinho que chegar primeiro ao final do percurso.

- Variações: podemos acrescentar obstáculos ao percurso, de modo que os carrinhos passem por baixo de cadeiras, mesas ou caixas de papelão formando um túnel, por cima de uma ponte feita de papelão, entre dois objetos, etc. Ao invés de ganhar apenas quem chegar primeiro, podemos estabelecer que ganharão o jogo todos que conseguirem chegar ao final do percurso, ou que ganhará quem chegar por último. Podemos fazer a corrida e, depois, sortear se o vencedor será quem chegou primeiro, em segundo, por último, etc. Podemos passar o barbante por um percurso, colocando o carrinho de um lado e a criança de outro, de modo que, ao puxar o barbante, a criança faça o carrinho aparecer pela porta, passar por baixo da cadeira, dar a volta na mesa, etc. Ao invés de amarrarmos os carrinhos, podemos fazer uma cunha ou rampa e soltar os carrinhos no alto da rampa, para que atinjam a faixa de chegada ou entrem em caixas (“garagens”) colocadas deitadas de lado, com a abertura voltada para a rampa. Também podemos utilizar carros pequenos, médios e grandes e tentar acertá-los dentro de caixas dos respectivos tamanhos. Podemos colocar os dedoches para dirigir os carros, para que a criança escolha qual é o seu personagem. Para encaixá-los, podemos fazer um rolinho de E.V.A. com um pedaço de elástico roliço na ponta, para que este elástico seja colocado em volta do carro (prendendo o dedoche ao carrinho). Podemos colocar um dedoche na frente e outro atrás de cada carro (piloto e co-piloto).

- Adaptações: caso as crianças participantes tenham dificuldades em permanecer sentadas no chão, a corrida pode ser feita sobre uma mesa (ou várias mesas posicionadas uma ao lado da outra). Se a criança apresentar dificuldades em manipular o barbante, podemos amarrar o carrinho com mais de um fio, formando uma corda mais grossa (para que não embole, podemos 
dar vários nós ao longo do barbante, unindo todos os fios). Se a criança apresentar visão subnormal, podemos realizar a corrida em uma superfície que contraste com a cor dos carrinhos e do barbante (também podemos amarrar o carrinho com mais de um fio de barbante, sendo alguns fios pretos e outros brancos ou amarelos). Se a criança só consegue puxar o barbante com uma mão, podemos estabelecer como regra que nenhum participante pode usar ambas as mãos, ou podemos amarrar o barbante em um rolo de papelão para que a criança gire o rolo (de modo que o barbante seja enrolado), puxando o carrinho. Caso a criança não consiga puxar ou manipular o rolo de papelão, outra opção é que um parceiro mantenha o fio do barbante sempre esticado, para que a criança bata a mão e empurre o fio para baixo, aproximando o carrinho (cada vez que a criança puxa o fio, o parceiro o enrola no rolo, para que o barbante se estique e a criança possa puxar novamente, até que o carrinho chegue ao final do percurso). Ou a criança pode segurar a ponta do barbante e o parceiro vai afastando sua cadeira de rodas para trás, de modo que o carrinho alcance a linha de chegada. A criança pode pegar o rolo no qual o barbante está amarrado e jogá-lo no chão, o que faz com que o carrinho se aproxime. Se a criança não consegue manipular o barbante, podemos colocar uma cunha a sua frente, então ela solta o carrinho no alto da cunha para que ele deslize até a faixa de chegada.

Desenvolvimento e aprendizagem:

- o que favorece: uso de ambas as mãos (ao revezá-las para puxar o barbante), atividade simbólica, noções de tempo e espaço.

- conceitos que podem ser trabalhados: agora (no momento da largada), por baixo, por cima, dentro (quando passa dentro do túnel), logo (quem vai chegar logo), antes, depois, lado direito, lado esquerdo (de acordo com o posicionamento dos carrinhos), entre (o carrinho que está entre os demais, ou os carrinhos devem transitar entre duas linhas, ou podemos colocar uma linha de fita crepe entre os dois carros), à frente, atrás, rápido, lento, longe, perto, primeiro, segundo, terceiro, último, início, fim, etc.

\section{Cidade:}

\section{Descrição sumária:}

Os participantes montam uma cidade com blocos ou caixas.

Tipo de brinquedo: 
- Material: blocos de madeira, caixas de papelão ou caixas de leite longa vida de diferentes tamanhos.

- Nível de estruturação: semi-estruturado.

- Tipo de regras: implícitas e simples.

- Nível de complexidade: pouco complexo.

- Nível de cooperação: cooperativo.

Usos do objeto:

- Procedimentos: os participantes distribuem os blocos formando casas e edifícios de diferentes tamanhos.

- Variações: podemos escrever nos blocos ou caixas os nomes de diferentes estabelecimentos comerciais e edificações existentes em uma cidade (além de escrever, podemos também colar figuras que representem estes estabelecimentos, caso a criança não saiba ler). Podemos delimitar o espaço que será ocupado pela cidade, o que pode ser feito colando fita crepe no chão ou mesa que será utilizada. Podemos colar dois pedaços de fita crepe paralelos, estabelecendo que ali seja a rua, por onde os carros transitarão (os carros ficarão entre as linhas). Também podemos acrescentar pontes e túneis de papelão. Os participantes escolhem quais edifícios ficarão de um lado e do outro lado da rua. Os participantes podem nomear que um estabelecimento ficará longe, perto ou entre outros edifícios. Podemos colocar uma praça, no centro da qual ficará, por exemplo, uma igreja e em volta da qual serão colocadas casas. Uma ou mais caixas poderão servir de garagem para os carros. Alguns móveis podem também fazer parte do cenário, por exemplo, algumas casas podem ficar em cima de uma cadeira, que simbolize uma montanha. A criança pode desenhar uma floresta e/ou uma praia e estabelecer de que lado da cidade estes espaços ficam. Podemos incluir alguns bonecos, que transitarão pela cidade e poderão ser colocados dentro das casas. Podemos também determinar que em alguns momentos, o carro deve parar para que alguém atravesse a rua ou porque o sinal está fechado e só depois seguir (alguém pode controlar um “semáforo”, mostrando cartões nas cores vermelha, amarela e verde). Podemos aumentar o nível de complexidade, construindo mais de uma rua e/ou estradas, ligando bairros ou cidades (cada criança ou grupo de crianças pode construir uma cidade).

- Adaptações: se a criança não consegue se locomover pelo espaço para fazer com que o carrinho transite pela cidade, podemos colocá-la sentada numa extremidade da rua e colocar um carro amarrado num barbante na outra extremidade, para que ela puxe a linha e o carro passe pela 
rua. Devemos oferecer blocos de tamanho adequado para a manipulação da criança, mas, caso não consiga manipular, ela pode colaborar, empurrando ou mostrando o bloco que quer utilizar e apontando ou olhando para o local que deseja que este seja colocado.

Desenvolvimento e aprendizagem:

- o que favorece: coordenação motora fina, praxia construtiva, criatividade, atividade simbólica, compreensão do funcionamento do trânsito e da cidade, noções de espaço, quantidade e tempo.

- conceitos que podem ser trabalhados: pequeno, médio, grande, maior, menor, lado, lado direito, lado esquerdo, muitos, poucos, mais, menos (ao estabelecer de que lado há mais prédios), longe, perto, entre, centro, em volta, dentro, fora, atrás, à frente (localização dos prédios ou casas), etc.

\section{Monte Castelo:}

Descrição sumária:

Os participantes constroem castelos e casas.

Tipo de brinquedo:

- Material: peças em formato de paredes, tetos e pisos que se encaixam, formando castelos e casas.

- Nível de estruturação: estruturado.

- Tipo de regras: implícitas e simples.

- Nível de complexidade: pouco complexo.

- Nível de cooperação: cooperativo.

Nome comercial: Monte Castelo

- Marca: Cemar Brinquedos.

- Componentes: 48 peças em formato de paredes, tetos e pisos, sendo alguns quadrados e outros redondos, para formar castelos ou casas.

Usos do objeto:

- Procedimentos: os participantes devem identificar as peças que se encaixam umas às outras, em seguida, deve encaixá-las, formando casas, prédios ou castelos de diferentes tamanhos.

- Variações: podemos delimitar com fita crepe a divisão entre duas cidades, de modo que cada participante coloque suas casas de um lado da divisão. Também podemos colocar 
bonequinhos ou os dedoches da Turma da Mônica dentro de cada casa ou dentro de cada andar dos prédios, indicando o locais que ainda estão vazios. É possível competir, para ver quem monta o prédio mais alto em menos tempo. Podemos construir um castelo no centro da cidade e colocar casas em volta dele.

- Adaptações: caso a criança apresente dificuldades para encaixar, podemos colocar um tapetinho antiderrapante sobre a mesa, estabilizando as peças para que a criança consiga manipulá-las. Para as crianças que apresentam limitação para a manipulação dos objetos, pode ser necessário auxiliá-la a encaixar as peças, visto que algumas delas são resistentes ao encaixe. Nestes casos, além da criança participar ao fazer força para encaixar as peças, devemos solicitar a colaboração ativa da criança em outras etapas da brincadeira, como ao identificar as peças que se encaixam umas nas outras e ao indicar o local onde cada casa deverá ser colocada.

Desenvolvimento e aprendizagem:

- o que favorece: coordenação motora fina, praxia construtiva, classificação (ao separar as peças no formato de paredes, tetos e pisos), atividade simbólica, noções de espaço e quantidade.

- conceitos que podem ser trabalhados: quadrado, redondo, pequeno, médio, grande, maior, menor, alto, baixo, lado, lado direito, lado esquerdo, muitos, poucos, mais, menos (ao estabelecer de que lado há mais casas), entre, meio, centro, em volta, vazio, dentro, fora, embaixo, em cima (local do prédio em que o boneco vai morar), nunca (ao dizermos que uma casa nunca pode ficar sem teto ou sem piso), etc.

\section{Massinha:}

Descrição sumária:

Os participantes fazem figuras de massinha, utilizando-se de forminhas de diversos formatos.

Tipo de brinquedo:

- Material: massinha de modelar, rolo de massa, forminhas para massinha ou para biscoito no formato de casas, bichos, carros, aviões, árvores, etc.

- Nível de estruturação: não estruturado.

- Tipo de regras: implícitas e simples.

- Nível de complexidade: pouco complexo.

- Nível de cooperação: cooperativo. 


\section{Usos do objeto:}

- Procedimentos: os participantes separam a massinha, amassando-a com as mãos e alisando-a com o rolo. Pressionam a forminha contra a massa, para que esta seja recortada no formato desejado. Separam a figura do restante da massa e a colocam sobre a mesa, no local desejado.

- Variações: a criança pode escolher se irá utilizar a massa inteira ou metade (o adulto pode nomear que, se cortarmos ao meio, ficaremos com duas metades). Os participantes podem, inicialmente, identificar as figuras representadas pelas forminhas, bem como seus tamanhos. Podem construir uma cidade de massinha, colocando casas enfileiradas, formando uma rua, ou podemos fazer mais ruas, colando pedaços de fita crepe paralelos. A criança estabelece de qual lado da rua ficará cada casa; em seguida, podemos numerá-las. A criança pode fazer bichos ou bonecos e estabelecer que cada um tenha uma casa. A criança pode, ao invés de construir uma cidade, construir um zoológico de massinha. Pode fazer figuras de frutas e dar uma metade da fruta para cada bicho. Pode também fazer um lago e colocar muitos peixes, além de colocar bichos ou casas em volta do lago. Ao invés de fazerem um zoológico, os participantes podem fazer figuras de bichos para vender no petshop. Neste caso, podem delimitar com fita crepe os espaços onde serão colocados os bichos de cada cliente (figuras de pessoas, feitas também de massinha), identificando o cliente que possui mais e menos bichos. Os bonecos podem ser colocados no centro, e seus bichos, em volta. Os participantes podem competir para ver quem faz mais figuras de massinha em um determinado tempo, sendo que as figuras de cada participante são colocadas de um lado da mesa, separadas por um pedaço de fita crepe. A criança pode ser incentivada a aproveitar toda a massinha que foi alisada, identificando se é possível fazer mais figuras com aquele mesmo pedaço da massa, adquirindo noções de tamanho e quantidade.

- Adaptações: caso a criança apresente espasticidade nos membros superiores, um parceiro pode ajudá-la a esticar os braços e a abrir as mãos, para que consiga bater, amassar e alisar a massinha. É possível também utilizar um rolo de massa de macarrão, colocando uma mão da criança em cada extremidade e ajudando-a a levar o rolo para frente e para trás, esticando a massa. Neste caso, quando a criança tem dificuldades para manter as mãos abertas, pode ser necessário utilizar um rolo de macarrão que tenha os cabos independentes do cilindro, ou seja, que as mãos da criança possam permanecer fechadas, segurando nos cabos, enquanto o rolo gira ao ser empurrado para frente e para trás. Pode ser mais fácil utilizar um pote com massinha de 
uma só cor (disponível em potes com 250 ou 500g), pois esta é geralmente mais macia e mais fácil de manipular que as massinhas vendidas em pequenas quantidades, de diferentes cores. $\mathrm{O}$ parceiro pode abrir a mão da criança, para que ela o ajude a apertar a forminha contra a massa. A criança pode ajudar a colocar a figura para fora da forminha, empurrando-a com um dedo. Se a criança não tiver controle para manipular as figuras confeccionadas, o parceiro pode manipulá-las e colocá-las nos locais indicados pela criança. Caso a criança tenha dificuldades em visualizar as figuras dispostas sobre uma mesa, podemos dispor as figuras sobre uma superfície inclinada (confeccionada em madeira ou papelão ou sobre uma almofada em formato de cunha).

Desenvolvimento e aprendizagem:

- o que favorece: coordenação motora grossa e fina, criatividade, noções de número, quantidade e espaço, associação termo a termo e pareamento (cada boneco tem uma casa, ou cada bicho tem uma fruta para comer), atividade simbólica, discriminação visual (ao reconhecer as figuras por meio de seus contornos).

- conceitos que podem ser trabalhados: pequeno, médio, grande, maior, menor, perto, longe (colocar uma figura longe ou perto da outra), cada, metade, inteiro, poucos, muitos, mais, menos, centro, em volta, entre, meio, lado, lado direito, lado esquerdo, primeiro, agora, antes, depois (ao explicarmos que, antes, precisamos amassar para, depois, recortarmos os bichos), quase (a figura está quase pronta), dentro, fora (ao retirar a massa da lata), etc.

\section{Restaurante (comidinha de massinha):}

Descrição sumária:

Os participantes brincam de restaurante, fazendo diferentes tipos de comida com a massinha de modelar.

Tipo de brinquedo:

- Material: massinha de modelar, forminhas de diferentes formatos, rolo de massa, pratinhos, faquinhas, etc.

- Nível de estruturação: semi-estruturado.

- Tipo de regras: implícitas e simples.

- Nível de complexidade: complexo.

- Nível de cooperação: cooperativo.

Nome comercial: Super Massa - Lanchinho. 
- Marca: Estrela.

- Componentes: uma "fábrica” de massa, réguas com diferentes aberturas, forminhas de picolé, rolinho, pratinho, moldes de vegetais, tesoura, faquinha e garfinho, espátula e dois potes de massa.

Usos do objeto:

- Procedimentos: os participantes alisam a massa e fazem figuras de comidinha. Também podem utilizar a "fábrica” de massa, colocando a massa de modelar no orifício e apertando a manivela, de modo que a massa passe pela régua e saia em diferentes formatos (macarrão, batata frita, etc.).

- Variações: ao invés de utilizar a “fábrica” de massas, é possível utilizar um kit para confeiteiro, para que a massa seja colocada no orifício e empurrada, para que saia no formato desejado, de acordo com o molde escolhido. Uma das crianças pode ser escolhida para ser o chefe de cozinha, que dará ordens para que seus ajudantes preparem os pratos. Os participantes devem se revezar no papel de chefe e de ajudantes de cozinha. Podem ser utilizadas bacias de diferentes tamanhos para que a massa seja dividida entre os participantes. Também podem utilizar figuras de bonecos, para que sejam os fregueses do restaurante. Os participantes determinam que pratos devem ser servidos antes e depois. Os participantes podem fazer muitas bolinhas, que podem ser pães de queijo ou bombons. Podem fazer figuras de bichos ou objetos, como se fossem biscoitos de diferentes formatos. Podem fazer bolos e pães, colocando-os dentro de uma caixa, que seria o forno. Os participantes indicam o tempo em que cada comida deve permanecer dentro do forno. Podem fazer pizzas de três tamanhos distintos, colocando tomate no centro e a borda em volta de cada uma delas. Ao invés de utilizar massinha, podemos utilizar panelinhas e desenhos de diferentes alimentos. Também podemos fazer círculos de papelão para fazer as pizzas e colocar em cima pecinhas de jogos (como os Pinos Mágicos - Elka) para fazer o queijo, o tomate, etc. Podemos preparar um alimento de verdade com a criança, como bolinhos; nesta atividade, podemos trabalhar os conceitos de antes e depois na seqüência de preparação do alimento; também podemos recortar os bolinhos pela metade, depois de prontos. Os participantes de um lado podem fazer os doces e os do outro lado, os salgados.

- Adaptações: visto que as forminhas do brinquedo têm cabos curtos, podemos alongá-los e engrossá-los, com E.V.A., facilitando a manipulação da criança. Outras adaptações para esta brincadeira estão descritas na brincadeira anterior. 


\section{Desenvolvimento e aprendizagem:}

- o que favorece: coordenação bimanual, coordenação olho-mão, criatividade, noções de tempo e quantidade, criatividade, atividade simbólica, modificações nas relações de poder e obediência às ordens (nos momentos em que os participantes se revezam nos papéis de chefe de cozinha e seus auxiliares).

- conceitos que podem ser trabalhados: antes, depois, pequeno, médio, grande, muitos, poucos, fino, grosso (diferentes espessuras de macarrão), metade, mais, menos, meio, centro, em volta, quase, agora (ao determinar quando a comida pode ser retirada do forno), lado, lado esquerdo, lado direito, em cima (colocar uma figura em cima do bolo), dentro, fora (ao retirar a massa da lata), nunca (quando são feitas comidas esquisitas), etc.

\section{Bichos de massinha:}

\section{Descrição sumária:}

Os participantes montam bichos de massinha.

Tipo de brinquedo:

- Material: massinha, cartolina, canetinha.

- Nível de estruturação: estruturado.

- Tipo de regras: implícitas e simples.

- Nível de complexidade: pouco complexo.

- Nível de cooperação: cooperativo.

Nome comercial: Massinha Xalingo - Meus Bichinhos.

- Marca: Xalingo Brinquedos.

- Componentes: duas caixinhas de massinha, figuras de cabeças, patas e rabos de animais fabricados em papel grosso.

\section{Usos do objeto:}

- Procedimentos: os participantes distribuem as partes do corpo dos bichos sobre a mesa, estabelecendo de que lados serão colocadas as cabeças, as patas e os rabos, para que não se misturem. Escolhem quais bichos farão e identificam quais são suas patas e rabos. Escolhem a cor de massa apropriada para cada bicho. Montam o corpo do bicho com a massinha, fazendo um rolinho ou uma bolinha, e encaixam as partes do seu corpo (patas, rabos e cabeças). 
- Variações: os participantes podem desenhar na cartolina e recortar as partes do corpo dos bichos, que serão encaixadas ao corpo feito de massinha. Também podem desenhar, na cartolina, um zoológico ou os ambientes nos quais os animais vivem, estabelecendo qual ficará de um lado, do outro, no centro, em cima, em baixo, perto ou longe. Os participantes podem identificar qual bicho tem mais ou menos patas, ou qual é o bicho maior e qual é o menor. Os participantes podem montar bichos "esquisitos”, misturando as partes dos corpos de bichos diferentes (neste caso, é possível nomear que, por exemplo, um elefante de verdade nunca poderia ter patas pequenas, senão não pararia de pé, ou que um cachorro de verdade nunca tem asas, ou que uma girafa nunca pode ser azul, etc.).

- Adaptações: pode ser necessário que o parceiro ajude a criança a manipular a massinha, ensinando-a a fazer bolinhas ou rolinhos, que formarão o corpo do bicho. A criança também pode necessitar de ajuda para encaixar as partes do corpo do bicho. Caso seja necessário, pode-se encapar as patas, cabeças e rabos dos bichos com plástico auto-adesivo, para que se tornem mais resistentes à manipulação. Também é possível confeccionar cabeças, patas e rabos maiores, com papel mais resistente (ou colar o papel em pedaços de cartolina, palitos de sorvete ou E.V.A), para que fiquem mais fáceis de serem manipulados pela criança. A criança pode ter mais facilidade em manusear a massinha vendida em potes de 250 ou 500g, por serem mais macias e por conterem um volume maior de massa, permitindo que se faça bichos maiores.

\section{Desenvolvimento e aprendizagem:}

- o que favorece: identificação das cores, coordenação motora fina, vocabulário (nomes de bichos), noções de espaço e quantidade.

- conceitos que podem ser trabalhados: duro, mole (consistência da massa), lado, lado direito, lado esquerdo, meio, metade, centro, entre, em cima, embaixo (em que parte do corpo colocamos as patas e a cabeça), à frente, atrás (de que lado colocamos o rabo), perto, longe (local em que cada bicho ficará), grande, médio, pequeno, maior, menor, nunca, muitos, poucos, mais, menos (número de patas de cada bicho), dentro, fora (retirar a massa da lata), etc.

\section{Zoológico:}

\section{Descrição sumária:}

Os participantes montam um zoológico.

Tipo de brinquedo: 
- Material: bonecos de diferentes animais existentes em zoológico. Pequenas caixas que podem servir de jaulas ou gaiolas.

- Nível de estruturação: estruturado.

- Tipo de regras: implícitas e simples.

- Nível de complexidade: pouco complexo.

- Nível de cooperação: cooperativo.

Nome comercial: Zoológico

- Marca: Nig Brinquedos.

- Componentes: peças feitas de plástico, no formato de diversos animais existentes em um zoológico (formando pares), árvores e cercas. Tabuleiro de papelão com desenho de zoológico. Figuras de um pipoqueiro, um sorveteiro e um vendedor de cachorro-quente, feitas em papelão e com um suporte plástico.

Usos do objeto:

- Procedimentos: delimita-se o espaço no qual o zoológico será construído (o que pode ser feito com fita crepe, ou com o tabuleiro do cenário do zoológico, no caso do jogo comercial). Os participantes dividem os bichos em pares e os distribuem pelo zoológico, estabelecendo qual ficará de que lado, qual ficará no centro do parque, quais bichos podem ficar na mesma jaula ou não, quais podem ficar perto ou devem ficar longe uns dos outros.

- Variações: os participantes podem enfileirar caixas de fósforo, para formar os muros e/ou grades. Podem ser incluídos bonecos que representem os visitantes do zoológico. Os participantes podem estabelecer de que horas a que horas o zoológico permanecerá aberto para visitantes. Podem ser incluídos bichos de outras marcas, de modo que haja animais de diferentes tamanhos. As crianças também podem identificar os bichos que nunca podem viver perto uns dos outros (por exemplo, os macacos nunca podem ser colocados na mesma jaula que os leões).

- Adaptações: visto que os brinquedos de plástico em formato de bichos geralmente são pequenos, as crianças podem apresentar dificuldades em manipulá-los e colocá-los de pé. Portanto, podemos fazer alguns suportes, colando os bichos com cola quente a pedaços de papelão, cartolina ou E.V.A., recortados em formato de círculos ou quadrados. O peso do material que forma o suporte faz com que, ao ser colocado sobre a mesa, o bicho permaneça de pé. Além disso, por ser mantido de pé, a criança terá maior facilidade em pegá-lo. Visto que há 
opções de bichos de diferentes tamanhos, deve ser utilizado um tamanho adequado à capacidade funcional da criança, facilitando o seu manuseio.

Desenvolvimento e aprendizagem:

- o que favorece: coordenação motora fina, atividade simbólica, aprendizagem de nomes de animais, noções de espaço, tempo e quantidade.

- conceitos que podem ser trabalhados: pequeno, médio, grande, maior, menor, muitos, poucos, perto, longe, mais, menos, em volta (as grades ficam em volta dos animais), centro, meio, par, lado, lado direito, lado esquerdo, entre, nunca, fora, dentro (fora ou dentro da jaula), etc.

\section{Bichos da terra e bichos do mar:}

\section{Descrição sumária:}

Os participantes montam cenários com bichos carimbados e recortados.

Tipo de brinquedo:

- Material: carimbos de diversos bichos, almofada com tinta para carimbo, duas folhas de sulfite e uma folha de cartolina, tesourinha, lápis de cor ou giz de cera.

- Nível de estruturação: semi-estruturado.

- Tipo de regras: explícitas e simples.

- Nível de complexidade: complexo.

- Nível de cooperação: cooperativo.

Usos do objeto:

- Procedimentos: os participantes carimbam figuras de bichos que vivem na terra em uma folha de sulfite e de bichos que vivem no mar, em outra folha. Colorem e recortam as figuras. Podem guardar os bichos recortados em duas caixas, de um lado, os bichos do mar e, do outro, os bichos da terra, para que não se misturem. Recortam a folha de cartolina ao meio, formando duas metades. Em uma metade, colocada de um lado da mesa, desenham um mar e, na outra metade, colocada do outro lado, desenham uma floresta e/ou fazenda (podem fazer árvores para os macacos, lagos para os jacarés, desertos para os camelos, etc.). Colam os bichos recortados nos locais adequados. Podem identificar de que tipo de bicho há mais e de que tipo há menos.

- Variações: antes de colar, as crianças podem pescar os peixes ou capturar os bichos utilizando uma mãozinha de silicone, tal como explicado na brincadeira que se segue. A criança também pode carimbar figuras de casas e meios de transporte, para montar uma cidade, 
colocando cada objeto em seu devido lugar (por exemplo, a praça pode ser colocada no centro, as casas, em volta, o avião, no céu, etc.). Também é possível montar cenários com situações inusitadas, como colocar o peixe no céu, o elefante no fundo do mar, o carro andando sobre o rio, comentando que tais fatos nunca poderiam acontecer de verdade. Ao invés de carimbar, pode-se recortar desenhos de bichos, encontrados em revistas e jornais, ou pode-se procurar e imprimir figuras da internet, para que as crianças recortem e colem. Caso a criança não queira montar os cenários, pode apenas carimbar livremente pelo papel, indicando se quer carimbar de um lado ou do outro, em cima ou embaixo da folha; é possível competir para ver quem carimba mais figuras em um determinado tempo. Podemos utilizar carimbos com bichos de diferentes tamanhos.

- Adaptações: caso a criança não consiga manipular os carimbos, podemos confeccionar adaptações com E.V.A. e cola quente, engrossando e aumentando os cabos dos mesmos. A criança pode necessitar de ajuda para esticar o braço em direção à almofada do carimbo e, em seguida, em direção ao papel. Nestes casos, a criança deve ser estimulada a escolher qual carimbo deseja e onde quer carimbar, em cima, embaixo, de um lado ou do outro da folha. Se a criança não conseguir visualizar a folha sobre a mesa, pode ser necessário o uso de uma superfície inclinada; assim, a folha é aproximada da criança e posicionada na altura de seus olhos, não sendo necessário que incline a cabeça para visualizar as figuras carimbadas. Se a criança apresenta déficits na acuidade visual, pode ser necessário utilizar carimbos com desenhos maiores. Caso a criança tenha dificuldades em manusear a tesoura, há a opção de utilizar tesoura com mola, que abre as lâminas automaticamente, de modo que a criança precise dominar apenas o movimento de flexão dos dedos. Outra possibilidade é que o parceiro ajude a criança nesta tarefa, posicionando a tesoura em seus dedos e segurando em sua mão, para que aprenda a fazer o movimento de abrir e fechar. Algumas crianças compreendem melhor este movimento e se divertem se fizermos uma comparação com outros movimentos, como, por exemplo, abrir e fechar a boca do jacaré (há tesouras com desenhos de bichos, facilitando esta comparação).

Desenvolvimento e aprendizagem:

- o que favorece: coordenação olho-mão, categorização (identificar em que categoria cada bicho se enquadra), ampliação do vocabulário (nomes dos bichos), criatividade, atividade simbólica, conhecimento dos locais onde os animais vivem, noções de espaço e quantidade.

- conceitos que podem ser trabalhados: atrás (passar a cola atrás da figura), mais, menos, muitos, poucos, metade, inteiro, meio, lado, lado direito, lado esquerdo, em cima, embaixo, perto, 
longe (local em que cada bicho ficará), nunca (quando montamos cenários esquisitos, por exemplo, com um peixe voando), pequeno, médio, grande, etc.

\section{Pescaria com peixes carimbados:}

Descrição sumária:

Os participantes carimbam diferentes figuras de peixes para depois pescá-los. Tipo de brinquedo:

- Material: carimbos de peixes, folhas de sulfite, tesourinha, três bacias ou caixas, mãozinha de silicone (nome: Pega geral - caneta; marca: DTC).

- Nível de estruturação: estruturado.

- Tipo de regras: explícitas e simples.

- Nível de complexidade: pouco complexo.

- Nível de cooperação: cooperativo (primeira fase) e competitivo (segunda fase).

\section{Usos do objeto:}

- Procedimentos: na primeira fase, os participantes carimbam as figuras de peixes em folhas de sulfite, recortam-nas e as colocam em uma bacia, no centro da mesa. Na segunda fase, cada participante, a sua vez, utiliza a mãozinha de silicone para grudar os peixes e pescá-los. Cada participante coloca seus peixes em uma bacia, colocada de um lado da mesa. Por fim, contam os bichos para ver quem conseguiu pescar mais.

- Variações: podemos utilizar duas bacias para colocar os peixes a serem pescados, para que a criança escolha em qual quer pescar. Ao invés de carimbar figuras de peixes, os participantes podem carimbar figuras de outros bichos, para caçá-los com a mãozinha de silicone. Podemos fazer desenhos de bichos ou peixes de diferentes tamanhos. Caso não haja a mãozinha de silicone, podemos utilizar uma varinha com um barbante amarrado e um pedaço de fita crepe ou fita adesiva na ponta do barbante, para que as figuras grudem ao aproximarmos a varinha.

- Adaptações: caso a criança tenha dificuldades em manipular a varinha ou a mãozinha de silicone, podemos engrossar seu cabo, com uma esponja e fita crepe ou com E.V.A. Se houver dificuldades em visualizar as figuras colocadas dentro da bacia, podemos espalhar os bichos sobre a própria mesa, para que sejam grudados na varinha ou mãozinha de silicone. Podem ser necessárias outras adaptações nos carimbos ou na execução da atividade de carimbar, conforme descritas na brincadeira anterior. 


\section{Desenvolvimento e aprendizagem:}

- o que favorece: coordenação olho-mão, coordenação bimanual (ao segurar a varinha com uma mão e soltar os bichos colados, com a outra mão), noções de tamanho e quantidade, aprender a aguardar a vez de jogar.

- conceitos que podem ser trabalhados: perto, longe, em cima, embaixo, meio, em volta (em que lugar do papel a figura será carimbada), pequeno, grande, médio, mais, menos, lado, lado direito, lado esquerdo, primeiro, antes, depois (quanto à seqüência da atividade ou quanto à vez de cada participante jogar), quase (quando quase conseguir pegar o peixe), vazio (quando o cesto está vazio, sem peixes), muitos, poucos, igual, diferente (carimbar ou pescar peixes iguais ou diferentes), dentro, fora (colocar ou retirar os peixes do cesto), etc.

\section{Pescaria:}

\section{Descrição sumária:}

Os participantes pescam peixes, utilizando uma varinha com imã.

Tipo de brinquedo:

- Material: peixes de diferentes tamanhos (feitos de plástico e com imã na boca), varinha de pescar com imã preso ao anzol, bacias e água.

- Nível de estruturação: estruturado.

- Tipo de regras: explícitas e simples.

- Nível de complexidade: pouco complexo.

- Nível de cooperação: competitivo.

Usos do objeto:

- Procedimentos: os participantes enchem a bacia com água e espalham os peixes. Em seguida, pescam os peixes utilizando a varinha de pescar. Ganha quem pescar mais peixes.

- Variações: podem ser feitos peixes de cartolina ou papel; neste caso, pode-se encher a bacia com grãos (como sagu cru) ou areia. No lugar do imã, pode-se utilizar pedaços de velcro ou ganchos que, entretanto, exigem maior coordenação por parte da criança. Além de peixes, podemos colocar outros animais ou objetos para serem pescados, tais como carrinhos e pássaros, para que a criança identifique que tais objetos nunca podem ficar no mar ou lago. Cada participante pode ter uma bacia ou lata para colocar os peixes que pescar, identificando de que lado da mesa ficarão os peixes de cada um. Pode-se estabelecer que, em cada rodada, só vale 
pescar os peixes de determinado tamanho, ou que só vale pescar com uma determinada mão. Também é possível brincar de pescar com os olhos fechados, sendo que ganha quem pescar menos peixes.

- Adaptações: pode ser necessário engrossar o cabo da varinha para que a criança consiga segurar. Algumas crianças não conseguem manter o objeto na mão, então, podemos enrolar um lenço ao redor de sua mão, prendendo-o com fita crepe, para que a varinha não caia contra a vontade da criança.

\section{Desenvolvimento e aprendizagem:}

- o que favorece: coordenação olho-mão e coordenação bimanual (ao segurar a varinha com uma mão e soltar o peixe pescado com a outra mão), noções de espaço e quantidade,

- conceitos que podem ser trabalhados: pequeno, médio, grande, muitos, poucos, menos, mais, quase (quase pescou o peixe), vazio (quando a bacia está vazia, sem peixes), perto, longe, nunca, lado, lado direito, lado esquerdo, dentro, fora (retirar ou colocar peixes na bacia ou quando o peixe pescado cai fora da bacia), antes, depois (quanto à ordem dos jogadores), comprido, curto (quanto ao tamanho do cabo da varinha de pescar), etc.

\section{Histórias com fantoches:}

\section{Descrição sumária:}

As crianças encenam histórias, utilizando fantoches de bichos e personagens. Tipo de brinquedo:

- Material: fantoches de diferentes bichos e personagens e livrinhos de história.

- Nível de estruturação: semi-estruturado.

- Tipo de regras: implícitas e simples.

- Nível de complexidade: pouco complexo.

- Nível de cooperação: cooperativo.

\section{Usos do objeto:}

- Procedimentos: um participante narra uma história, enquanto os demais participantes a encenam com fantoches.

- Variações: antes de iniciar a história, podem ser comentadas as características dos personagens. São colocados, de um lado, os personagens envolvidos na história e, do outro, os não envolvidos. Para contar a história, mesmo que a criança não saiba ler, ela pode inventar uma 
narrativa tendo por base os desenhos dos livros; ou o adulto pode ler a história para a criança, enquanto ela movimenta os personagens envolvidos em cada cena. A criança pode ser solicitada a apontar para os desenhos solicitados pelo adulto, identificando, por exemplo, onde há mais bichos, qual é o objeto pequeno e qual é o grande, ou qual personagem está fazendo algo agora. A criança pode segurar um fantoche com cada mão, sendo estimulada a mover o lado que segura o personagem envolvido na cena. Um participante pode iniciar a história e, em seguida, passar o fantoche para outra criança, para que esta termine a história. Após cada história, as crianças podem identificar o que aconteceu antes e depois.

- Adaptações: caso a criança não consiga abrir os dedos para mover o fantoche, este pode ser encaixado sobre a mão da criança, mesmo que esta permaneça fechada. Para que a criança possa visualizar melhor as figuras do livro, este pode ser posicionado sobre uma superfície inclinada.

\section{Desenvolvimento e aprendizagem:}

- o que favorece: atividade simbólica, criatividade, noções de tempo, coordenação motora fina (ao movimentar os fantoches), discriminação visual (ao identificar as figuras dos livros), fluência verbal e ampliação do vocabulário.

- conceitos que podem ser trabalhados: agora, nunca, sempre, primeiro, antes, depois, cedo, tarde, logo, lado, lado direito, lado esquerdo, mais, menos, muitos, poucos, maior, menor, pequeno, médio, grande, quase (quando a história está quase acabando), etc.

\section{Revistinhas e dedoches:}

Descrição sumária:

Os participantes contam histórias utilizando dedoches (fantoches de dedo) e gibis.

Tipo de brinquedo:

- Material: gibis e dedoches de diferentes personagens.

- Nível de estruturação: semi-estruturado.

- Tipo de regras: implícitas e simples.

- Nível de complexidade: pouco complexo.

- Nível de cooperação: cooperativo.

Nome comercial: Dedoches da Turma da Mônica ou Dedoches da Turma do Chico Bento.

- Marca: Brinquedos Algazarra. 
- Componentes: cada caixa contém bonecos de cinco personagens, confeccionados em plástico, sendo que cada um apresenta um orifício na parte inferior, para que possam ser encaixados nos dedos.

Usos do objeto:

- Procedimentos: os participantes escolhem a história que querem contar. Lêem a história e identificam os dedoches dos personagens envolvidos na mesma. Em seguida, narram a história novamente, encenando-a com os personagens.

- Variações: a criança pode ser estimulada a apontar para as figuras solicitadas pelo adulto, sendo questionada sobre o personagem que está executando (agora) uma determinada ação. Também podemos perguntar o que a criança acha que o personagem fará depois de uma dada cena. Podemos colocar vários dedoches em cada mão da criança, para que ela movimente o lado correspondente ao personagem envolvido em cada cena. Os dedoches podem ser incluídos em outras brincadeiras, sendo visitantes do zoológico, pessoas que circulam pela cidade de blocos ou que dirigem os carros. Estes bonecos também podem ser colocados dentro das casas do brinquedo Monte Castelo. Ao invés de utilizar gibis, é possível utilizar um software de computador da Turma da Mônica e da Turma do Chico Bento, no qual a criança monta suas próprias historinhas em quadrinhos. Caso a criança não tenha acesso ao computador para montar sua própria história, podemos já deixar as cenas prontas e impressas, apenas para que a criança decida em qual ordem elas ocorrerão. Ao invés de utilizar dedoches comprados prontos, também é possível confeccionar ou comprar fantoches de dedo, feitos em feltro.

- Adaptações: se a criança mantém as mãos fechadas e não tem movimentos independentes dos dedos, para que ela consiga segurar o dedoche podemos encaixá-lo em um rolinho de E.V.A. Se a criança permanece apenas em pronação (com a palma da mão voltada para baixo), podemos colocar um pedaço de arame dentro do rolinho de E.V.A., para que este seja contorcido, de modo que o personagem permaneça voltado para cima (de pé). Se a criança não consegue manter a mão fechada, podemos encaixar o dedoche em um rolinho menor, preso com um elástico na outra ponta; este elástico pode ser colocado ao redor da mão da criança, de modo que não caia mesmo quando a criança abrir a mão involuntariamente.

\section{Desenvolvimento e aprendizagem:}

- o que favorece: coordenação motora fina, discriminação visual (ao identificar as figuras nas revistas), atividade simbólica, noções de tempo e quantidade. 
- conceitos que podem ser trabalhados: muitos, poucos, agora, antes, depois, lado, lado direito, lado esquerdo, cedo, tarde, mais, menos, etc.

\section{Quadro imantado:}

Descrição sumária:

Os participantes montam cenários e histórias, utilizando o quadro imantado e as figuras imantadas.

Tipo de brinquedo:

- Material: quadro imantado ou superfície na qual possam ser grudados imãs (por exemplo, porta de geladeira ou mesa de ferro), figuras de bichos, pessoas, frutas e objetos, confeccionadas em madeira, papel ou E.V.A. com imã colado na parte posterior das figuras.

- Nível de estruturação: semi-estruturado.

- Tipo de regras: implícitas e simples.

- Nível de complexidade: pouco complexo.

- Nível de cooperação: cooperativo.

Nome comercial: Quadro imantado.

- Marca: Trenzinho.

- Componentes: quadro imantado e figuras de madeira com imã.

Usos do objeto:

- Procedimentos: os participantes montam uma cena, utilizando as figuras escolhidas. Em seguida, podem narrar a história que imaginaram.

- Variações: o adulto pode nomear o tamanho da figura escolhida, bem como o local no qual a criança coloca cada figura (de um lado, do outro, em cima, embaixo, perto ou longe de outra figura, entre outros personagens, no centro ou em volta de outros personagens, etc.). Os participantes podem brincar de localizar figuras de determinado tipo, colocando no quadro apenas figuras de uma mesma categoria (por exemplo, apenas frutas ou animais), ou podem colocar no quadro apenas figuras que tenham alguma característica em comum, como a letra do nome ou a cor do desenho. Em seguida, podem identificar de qual tipo há mais figuras. Um participante pode colocar algumas figuras no quadro, para que o outro participante monte uma frase ou invente uma história com elas. Estas figuras podem também ser incluídas em outras brincadeiras, por exemplo, podem ser utilizadas figuras de pessoas, que são os clientes do restaurante ou do 
petshop. Também podemos utilizar as peças de jogos de seqüências lógicas ${ }^{57}$, colando pedaços de imã atrás das figuras, para que a criança identifique a ordem na qual as cenas ocorrem. Neste caso, podemos pedir para que a criança veja uma cena e imagine o que ocorrerá depois. Ou podemos mostrar apenas a cena do meio, pedindo para que a criança pense o que pode ter acontecido antes e depois desta. Ao invés de utilizar as figuras imantadas, a criança também pode montar histórias, recortando figuras de revistas e colando-as em cadernos ou em folhas de cartolina.

- Adaptações: caso a criança não apresente comunicação verbal, ela pode escolher as figuras que deseja, enquanto o adulto nomeia o que cada personagem está fazendo, sempre perguntando para a criança se sua interpretação está correta. Ou, o adulto pode narrar uma história, enquanto a criança coloca no quadro os personagens envolvidos. Se a criança tiver dificuldades em alcançar o quadro preso à parede, o quadro imantado pode ser colocado inclinado (sobre uma cunha, por exemplo) na frente da criança, facilitando o manuseio das figuras. Também podem ser colocadas pequenas alças ou rolinhos presos na parte da frente das figuras, facilitando que estas sejam grudadas e desgrudadas do quadro.

Desenvolvimento e aprendizagem:

- o que favorece: coordenação olho-mão, classificação (ao escolher figuras de determinado tipo), pensamento lógico e seqüenciação (ao utilizarmos seqüências lógicas), ampliação do vocabulário (nomes de frutas e animais), atividade simbólica, noções de tempo, quantidade e espaço.

- conceitos que podem ser trabalhados: mais, menos, pequeno, médio, grande, muitos, poucos, logo, agora, antes, depois, cedo, tarde, longe, perto, lado, lado direito, lado esquerdo, entre, centro, em volta, em cima, embaixo, etc.

\section{Futebol de bolinhas de gude:}

\section{Descrição sumária:}

Os participantes jogam futebol, utilizando bolinhas de gude.

Tipo de brinquedo:

\footnotetext{
57 Jogos com seqüências de cenas. A criança deve identificar as figuras que fazem parte de uma mesma cena e deve ordená-las, para que estabeleçam uma seqüência lógica de acontecimentos.
} 
- Material: bolinhas de gude e um tabuleiro feito em madeira, com o desenho de um campo de futebol e com alguns pininhos que simbolizam os jogadores e servem de obstáculos.

- Nível de estruturação: estruturado.

- Tipo de regras: explícitas e simples.

- Nível de complexidade: complexo.

- Nível de cooperação: competitivo.

Usos do objeto:

- Procedimentos: os jogadores escolhem seu lado do campo. Colocam uma bolinha de gude no centro do campo e decidem quem começa jogando a bola. Cada participante utiliza os dedos para “chutar” a bolinha, empurrando ou dando petelecos. Cada jogador deve tentar impedir que o outro jogador faça gols, bem como deve tentar acertar a bola no gol do adversário. Sempre que a bolinha sair do campo, deve ser colocada novamente no centro do mesmo.

- Variações: caso não haja um tabuleiro em formato de campo de futebol, podemos utilizar uma caixa de papelão, cortando os lados para que as laterais fiquem baixas e colando uma cartolina ou folha de E.V.A. no fundo, para que fique liso. A criança pode participar da confecção do campo de futebol, ajudando a pintá-lo. Também devemos fazer um buraco de cada lado, para o gol. Podemos usar bolinhas de gude pequenas, médias e grandes, sendo que a criança escolhe com qual brincaremos antes e com qual brincaremos depois. Podemos estabelecer se utilizaremos os dedos para "chutar” as bolinhas (dar peteleco ou empurrar com o dedo) ou se utilizaremos uma varinha. Ao invés do adversário tentar defender o gol enquanto o outro joga, pode-se estabelecer que, em cada rodada, um tenta acertar o gol do outro, sem que o outro fique defendendo. Podemos ainda dificultar, deixando as bolas grandes no campo, como se fossem jogadores, então os participantes devem acertar as bolas pequenas ou médias no gol, sem deixar que as grandes entrem. Quando um jogador fizer um gol, a bolinha pode ser colocada em uma bacia, para que depois possam contar quem fez mais gols.

- Adaptações: ao invés de utilizar os dedos, a criança pode utilizar, para acertar a bola, um palito encaixado em sua mão. Caso a criança tenha dificuldades para a coordenação motora, podem ser utilizadas bolas um pouco maiores, facilitando a manipulação.

\section{Desenvolvimento e aprendizagem:}

- o que favorece: coordenação olho-mão, noções de espaço, tamanho e quantidade. 
- conceitos que podem ser trabalhados: mais, menos, lado, lado direito, lado esquerdo, pequeno, médio, grande, centro, metade (metade das bolinhas para cada jogador), muitas, poucas, quase (quando quase acertar o gol), antes, depois (quanto à seqüência dos jogadores), etc.

\section{Caça ao Tesouro:}

Descrição sumária:

Os participantes seguem as pistas até encontrarem o tesouro.

Tipo de brinquedo:

- Material: desenhos indicando as pistas e um tesouro (por exemplo, um presentinho ou um saquinho com doces ou moedas de chocolate).

- Nível de estruturação: estruturado.

- Tipo de regras: explícitas e complexas.

- Nível de complexidade: complexo.

- Nível de cooperação: cooperativo ou competitivo.

\section{Usos do objeto:}

- Procedimentos: o local deve ser preparado antes da chegada das crianças. Assim, um adulto ou outro participante prepara as pistas, sendo que um desenho indica o local onde se encontrará a primeira pista. Por exemplo, um desenho pode indicar que há algo sobre uma mesa; então, pedimos para que a criança indique onde está a mesa e mostre o que há sobre ela. Sobre a mesa, encontra-se outra pista, por exemplo, um desenho com algo debaixo da cadeira. Então, a criança deve achar a outra pista que está debaixo da cadeira, sendo que esta pista pode mostrar, por exemplo, um desenho de algo entre o armário e a mesa. Outras pistas podem mostrar, ainda, algo dentro do armário, fora de uma caixa, dentro da gaveta, atrás da porta, perto da janela, entre outras, até que a criança encontre o tesouro.

- Variações: após terminarem o percurso, os participantes podem relembrar qual foi a seqüência das pistas, dizendo o que ocorreu antes e depois de cada pista. Se as crianças souberem ler, ao invés de utilizar desenhos podemos utilizar frases. Podemos, ainda, colocar dois tesouros (por exemplo, colocamos um saquinho com poucas moedas de chocolate; com estas podemos deixar outra pista que leve a outro tesouro com muitas moedas). Ao invés de procurarem por um tesouro, as crianças podem procurar por uma criança que esteja escondida no final do percurso. 
- Adaptações: caso a criança não consiga se locomover pelo espaço à procura das pistas, podemos levar sua cadeira de rodas em direção às mesmas, sendo os locais apontados pela criança. Se a criança não souber apontar ou olhar para o local onde se encontra a próxima pista, um parceiro pode indicar vários locais, sendo que a criança pode sorrir, ou fazer outro sinal, quando for indicado o local mostrado pelo desenho.

Desenvolvimento e aprendizagem:

- o que favorece: noções de tempo, quantidade e espaço, discriminação visual (ao identificar as figuras desenhadas).

- conceitos que podem ser trabalhados: dentro, fora, perto, em cima, embaixo, centro, entre, antes, depois, agora, atrás, à frente, lado, lado direito, lado esquerdo, mais, menos, muitos, poucos, etc.

\section{Jogo da memória:}

\section{Descrição sumária:}

As crianças procuram pelos pares dos desenhos.

Tipo de brinquedo:

- Material: pares de figuras confeccionadas em cartolina, papel ou madeira.

- Nível de estruturação: estruturado.

- Tipo de regras: explícitas e complexas.

- Nível de complexidade: complexo.

- Nível de cooperação: competitivo.

Nome comercial: Jogo da memória “Ursinho e seus Amigos”.

- Marca: Sonata.

- Componentes: tabuleiro no qual são encaixadas figuras de bichos; 25 peças no formato de ursinhos, que são encaixadas sobre as figuras, visando escondê-las.

\section{Usos do objeto:}

- Procedimentos: no caso do jogo comercial, os participantes colocam os pares das figuras espalhadas pelo tabuleiro. Em seguida, encaixam os ursinhos sobre as figuras, escondendo-as. Depois, na sua vez, cada participante deve procurar por um par de bichos. Quando a criança não conseguir encontrar o par, passa a vez para o adversário. Ao encontrar o par, a criança pega os 
ursinhos que escondiam as figuras; por fim, podemos contá-los para identificar o jogador que ganhou mais ursos (ou seja, que encontrou mais pares).

- Variações: os ursinhos adquiridos por cada participante podem ser colocados de um lado do tabuleiro, para que depois sejam enfileirados e contados. Ao invés de fazer uma competição, uma mesma criança pode tentar encontrar os pares dos bichos. Neste caso, ela escolhe uma figura e tenta encontrar o seu par, pegando quantos ursinhos forem necessários. Ao procurar pelos pares, um adulto pode dar dicas, dizendo se o bicho procurado se encontra no centro, de um lado ou do outro do tabuleiro, embaixo, em cima ou entre outros bichos. Também podemos montar o jogo da memória: com figuras retiradas de revistas ou do computador, com duas cópias de fotos das crianças participantes, com placas de diferentes texturas para serem identificadas pelo tato, ou com potinhos com diferentes objetos dentro, de modo que os pares sejam encontrados pelo som.

- Adaptações: ao contrário de jogos da memória que apresentam cartelas com figuras, este jogo facilita a manipulação da criança, visto que a criança deve pegar os bonecos dos ursinhos e não as figuras de papel. Contudo, caso a criança tenha muita dificuldade para a coordenação motora e não consiga manusear os ursinhos, um outro participante pode pegar os ursinhos escolhidos pela criança. Quando utilizamos jogo da memória convencional, podem ser coladas caixinhas de palitos de fósforo na parte posterior das cartelas, facilitando o manuseio da criança. Desenvolvimento e aprendizagem:

- o que favorece: memória, ampliação do vocabulário, discriminação visual, aprender a aguardar a vez de jogar, noções de espaço e quantidade.

- conceitos que podem ser trabalhados: mais, menos, par, lado, lado direito, lado esquerdo, centro, meio, entre, em cima, embaixo, perto, longe, igual, diferente, muitos, poucos, antes, depois (quanto à seqüência dos jogadores), etc.

\section{Varetas gigantes:}

Descrição sumária:

Os participantes tentam pegar uma vareta por vez, sem mexer as demais varetas.

Tipo de brinquedo:

- Material: varetas grandes.

- Nível de estruturação: estruturado.

- Tipo de regras: explícitas e complexas. 
- Nível de complexidade: complexo.

- Nível de cooperação: competitivo.

Nome comercial: Maxi Pega Vareta.

- Marca: Elka.

- Componentes: 32 varetas coloridas, com 35 centímetros de comprimento cada.

Usos do objeto:

- Procedimentos: um participante segura todas as varetas e as solta, para que se espalhem pelo chão. É determinada a seqüência dos jogadores. Cada jogador tenta pegar uma vareta sem que as demais se mexam. Caso consiga fazê-lo, poderá tentar pegar outras varetas. Quando outras varetas se mexerem, o jogador passa a vez para o próximo. Vence quem pegar mais varetas.

- Variações: antes de utilizar as varetas gigantes, a criança pode brincar com as varetas de tamanho convencional, para que possa compará-las com as varetas gigantes. Ao escolher uma vareta, pode-se nomear se esta se encontra de um lado, do outro, em cima ou embaixo das demais. Cada jogador pode colocar suas varetas de um lado, para que depois possam ser contadas. De acordo com as regras originais, cada cor de vareta equivale a uma pontuação, sendo vencedor o jogador que obtiver a maior pontuação. Contudo, caso a criança não saiba contar, pode-se considerar vencedor o jogador que obtiver o maior número de varetas. No final do jogo, também podemos contar para verificar quem obteve mais varetas de cada cor. Pode-se determinar que, a cada rodada, os participantes só podem utilizar uma determinada mão para pegar as varetas. Ao invés de se determinar, no começo da brincadeira, que ganhará quem obtiver mais pontos, pode-se esperar para que, depois que todas as varetas tenham sido pegas, seja feito um sorteio para determinar se o vencedor será quem obteve mais ou menos varetas, ou se vencerá quem obteve mais varetas de uma determinada cor.

- Adaptações: estas varetas, por serem grandes e mais grossas que as varetas convencionais, facilitam a sua manipulação. Contudo, por serem mais pesadas, é mais difícil pegar uma vareta sem que as demais se mexam. Assim, visto que algumas crianças também apresentam dificuldades na coordenação motora, pode-se determinar que valha mexer um pouco, mas não muito, as demais varetas enquanto o jogador tenta pegar uma delas. Caso a criança não consiga manipular as varetas, um parceiro pode pegar as varetas escolhidas pela criança, sendo que esta também pode guardá-las, para que possa participar ativamente da brincadeira. 


\section{Desenvolvimento e aprendizagem:}

- o que favorece: coordenação motora fina, identificação de cores, noções de quantidade e espaço.

- conceitos que podem ser trabalhados: mais, menos, antes, depois, muitas, poucas, lado, lado direito, lado esquerdo, pequeno, grande, fino, grosso, etc.

\section{Bebê:}

\section{Descrição sumária:}

A criança brinca de cuidar de um bebê.

Tipo de brinquedo:

- Material: um bebê de plástico ou pano, roupinhas, mamadeira, banheira, água, sabão, etc.

- Nível de estruturação: estruturado.

- Tipo de regras: implícitas e simples.

- Nível de complexidade: pouco complexo.

- Nível de cooperação: cooperativo.

\section{Usos do objeto:}

- Procedimentos: a criança brinca de cuidar de um bebê, sendo pré-estabelecidas todas as etapas necessárias, por exemplo: antes de alimentar, é necessário dar banho no bebê; para isso, primeiro, precisamos retirar sua roupa e sua fralda, colocar água na banheira, ensaboar o bebê, enxaguá-lo e enxugá-lo; depois, precisaremos colocar novamente a roupa e pentear seu cabelo. Por último, iremos dar a mamadeira.

- Variações: ao dar banho no bebê, podem ser nomeadas as partes de seu corpo que precisam ser lavadas. Podem ser utilizados bonecos de diferentes tamanhos, para que a criança possa compará-los. Para que não se misturem, as roupas do boneco pequeno podem ser colocadas de um lado, as do boneco grande, do outro lado e, as do boneco médio, entre as roupas dos demais. Pode ser contado para ver qual boneco possui mais roupas. Caso haja mais de uma criança, é possível competir para ver quem consegue retirar e colocar mais peças de roupa em um determinado tempo.

- Adaptações: caso a criança tenha dificuldades em manipular os botões e cordões das roupinhas, pode ser necessário substituí-los por velcro. Se a criança tiver dificuldades em 
manusear os objetos, podemos encaixar uma esponja em sua mão, para que possa participar do momento de lavar o boneco.

Desenvolvimento e aprendizagem:

- o que favorece: esquema corporal, atividade simbólica e noções de tempo e quantidade.

- conceitos que podem ser trabalhados: antes, depois, agora, primeiro, por último, lado, lado direito, lado esquerdo, entre, mais, menos, pequeno, médio, grande, etc. 